\title{
A GENERIC MONOGRAPH OF THE MELIACEAE ${ }^{1}$ )
}

\author{
T. D. PENNINGTON ${ }^{2}$ ) and B. T. STYLES ${ }^{\text {) }}$
}

\section{CONTENTS}

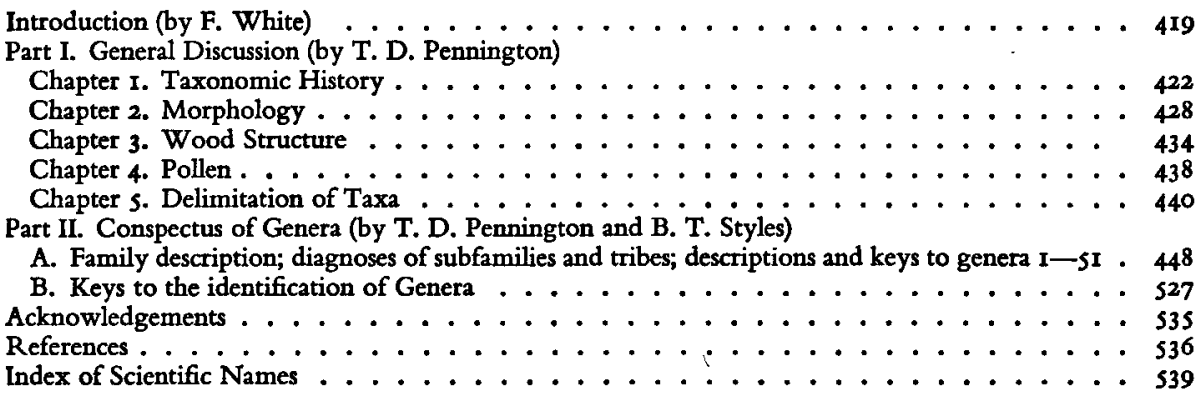

\section{INTRODUCTION}

\section{by F. White}

Of all plant families the Meliaceae is among the more useful to man, chiefly for its high quality timbers and for the ease with which some species can be grown in plantations. Almost confined to the tropics, its species nevertheless pervade them, and occur, often conspicuously, in a variety of habitats from rain forest to mangrove swamp and semidesert.

For its size, the family probably contains a wider range of floral and fruit structures than any comparable group. In what other family is there such a diversity of primitive 'arillate's seeds, side-by-side with such an array of derived fruits and seeds, and still connected by intermediates? Or, to take the flower, where else can be found such a diversity of forms, from the minute, but structurally complex, flowers of Aglaia, often no larger than a pin-head, to the moth-pollinated flowers of some Turraea, with their slender staminal tubes reaching a length of $12 \mathrm{~cm}$ or more?

This diversity is a source of rich material for the student of evolution and of plant and animal inter-relationships, and provides an interest so often lacking in taxonomic studies. But it is also a source of taxonomic difficulty, as the taxonomic history of the group so clearly shows.

With a few exceptions mentioned below, most of the genera currently recognized as

1) Materials for a Monograph of the Meliaceae III. This series is being prepared at the Commonwealth Forestry Institute, Oxford, U.K.

श) Present address: Clarke's Farmhouse, Northmoor, Oxon, U.K.

3) Department of Forestry, Commonwealth Forestry Institute, Oxford, U.K.

4) Curator of the Herbaria, Botany School, Oxford University, U.K.

5) Used in the wide sense of Corner. In my opinion careful comparative and developmental studies are needed before the term can be applied more precisely. 
Meliaceous have been regarded as such since the time of their discovery. But there has been persistent disagreement as to the number of genera and their circumscription, and as to the best way to accommodate them in tribes and subfamilies. Even the number of families has been uncertain from the time of de Jussieu (I789) to that of Harms (I940).

More than in other families, this uncertainty has been due to the diffuse and often reticulate nature of the variation, frequently aggravated by a lack of complete material. There is a quasi-absolute dearth of information on the functions of the structures concerned. Parallel evolutionary trends are numerous and have affected the flower and fruit independently. Complete material necessary for generic diagnosis has often been, and in some cases still is, lacking. Much of the material on which this work is based was specially collected in South-East Asia and tropical America by Dr. Pennington himself, and, to a lesser extent, by Dr. Styles and myself in Africa.

Previous workers have often attached undue weight to single diagnostic characters, e.g. position of anther insertion on the staminal tube or presence or absence of endosperm. These can now be shown to have arisen or been lost, as the case may be, more than once, and to be poorly correlated with other characters. Some genera and most tribes can only be diagnosed by using a combination of several 'differential' characters (as defined by White, I962), each one of which, taken separately, may occasionally break down, although the combination itself reveals a pronounced discontinuity. Thus, members of the Turraeeae cannot be distinguished from all other Meliaceae on the basis of a single diagnostic character. Most character-states typical of Turraeeae have at least a few exceptions in the tribe, and also occur, at least occasionally, in other tribes, but always in markedly different combinations. The overall pattern, however, is such that all members of the Turraeeae possess many more of the tribal character-states than any excluded species. Thus, the Turraeeae is objectively circumscribed, being based on a real and definable gap in the variation pattern. Similarly for other subfamilies and genera.

Only a selection of available characters has been used in the diagnoses of the tribes and in the keys to and descriptions of the genera. Further study, especially in the field, is expected to reveal complex syndromes of confirmatory characters, for the most part individually small, but well correlated among themselves, and functionally related to the methods of pollination or means of dispersal.

Many Meliaceae have unisexual flowers, but always with well-developed rudiments of the opposite sex. In contrast to most rudimentary structures, the shapes and positions of these, relative to other parts of the flower, are remarkably constant within species and genera and even tribes, and vary greatly between them. Compare, for instance, the flowers of Aglaieae (figs. 9-10) and Guareeae (figs. II-I4). Their function is to restrict access to nectar, so that it is only available to the 'right kind' of insect, which must adopt postures that make possible the transfer of pollen from fertile anther to receptive stigma.

There are few observations on this, but I myself have seen how the small Hymenoptera which visit the flowers of Trichilia havanensis Jacq. are forced to insert their proboscides into very narrow slots between the anthers or antherodes, and, in so doing, pick up pollen from the male flowers and transfer it to the stigmatic surfaces of the female flowers. A glance at the illustrations in this generic monograph is sufficient to show that the precise configuration of antherodes and pistillodes in relation to other floral parts is likely to prove of considerable taxonomic value and evolutionary interest, when the floral biology of the family has been adequately investigated.

The claims of certain genera to inclusion in the family have been frequently disputed up to the present time. Of the two most-controversial genera, Nymania and Ptaeroxylon, the present study convincingly shows that the former is Meliaceous and that the latter, 
as had been previously suggested (Leroy, 1959, I960 a; White \& Styles, I966), must be excluded.

Shortly after its discovery, the un-Meliaceous-looking Nymania was placed by de Jussieu (1789) in his Melieae (as Aitonia). Some subsequent authors have sought a place for it elsewhere. As recently as 1966, Airy-Shaw kept it in the monotypic family Aitoniaceae of Harvey \& Sonder. In the present work it is shown that, both in its pollen grain and secondary xylem, it clearly belongs, not merely to Meliaceae, but to the Turraeeae, and that in its floral structure it is connected to Turraea by other genera, particularly by the recently discovered Malagasy genus, Calodecaryia.

Another monotypic South African genus, Ptaeroxylon, which was formerly prized for its valuable timber, together with its Malagasy relative, Cedrelopsis, have sometimes been placed in Meliaceae, sometimes elsewhere. At the onset of this study, it was known that Ptaeroxylon differed markedly from all other Meliaceae, at that time investigated, in certain features of its pollen grain. Since a few other undisputed Meliaceae, notably certain species of Turraea, were also known to be anomalous in other pollen grain features, it was decided to regard the matter as sub judice until the pollen and wood-structure of the whole family had been adequately studied and the gross morphology re-assessed. It was then confirmed that Ptaeroxylon is distinct from all Meliaceae in its pollen grain and secondary xylem. The resemblances between the capsular fruit and winged seed of Ptaeroxylon and Swietenioideae prove to be superficial.

Of the four subfamilies recognized here, the two largest, Swietenioideae, with woody capsular fruit and winged seeds, and Melioideae, with 'arillate' seeds or fleshy indehiscent fruits, have been recognized, in some form or other, since I789. Their rank and circumscription, however, have frequently been debated. Adrien de Jussieu (1830) treated them as families, an opinion which Harms, as recently as 1940, suggested could be justified, though he himself had them as subfamilies, together with a third, based on Cedrela.

Apart from the inclusion or otherwise of Cedrela and the related Toona, the Swietenioideae has remained a remarkably stable taxon. Only the inclusion or otherwise of the mangrove genus $X Y$ locarpus and the related Carapa has been seriously disputed; on the position of these two genera opinion has been evenly divided. Harms placed them in Melioideae, but the wood anatomist Kribs (1930), on the basis of wood anatomy alone, included them in Swietenioideae, where he thought Cedrela also belongs. Kribs produced a key to 36 genera of Meliaceae, implying that each genus is distinct in its wood anatomy. If this could be substantiated, xylotemy would indeed be shown to be a powerful taxonomic tool. The present study, however, based on much more material than was available to Kribs, reveals that few genera are distinct in their secondary xylem, though in some cases it provides useful confirmatory characters. In the present study, in which the secondary xylem of 230 species was examined, convincing evidence is presented which shows that Cedrela (and Toona) and Xylocarpus and Carapa have so much in common with the rest of Swietenioideae that their exclusion is unjustified. The secondary xylem of Swietenioideae, circumscribed to include these genera, is virtually uniform and constantly different from that of Melioideae. The pollen, on the other hand, of most Swietenioideae and most Melioideae is so similar that it confirms the decision to treat them as subfamilies, rather than as families.

Additional confirmation comes from another source. Careful study of two little-known Malagasy genera, Capuronianthus and Quivisianthe, has shown that they provide connecting links between the two larger subfamilies. They are, however, so different from each other, and, despite their intermediate position, so different from Swietenioideae and Melioideae, that it has proved necessary to establish two new subfamilies to accommodate them. 
The present study is based on part of a monographic study of the family, begun by Dr. Styles in 1960 , starting with the economically important genera. Shortly afterwards Dr. Pennington undertook, among other things, a generic revision of the Melioideae, which resulted in a doctoral thesis, parts of which are incorporated here. It was expected that Dr. Styles and Dr. Pennington would obtain posts which would enable them to complete the monograph. Because of the economic situation this did not happen and further progress has been less rapid than was hoped. It was originally intended, before publication, to undertake surveys of the chromosome cytology and germination and seedling morphology. The importance was realized of investigating the development and differentiation of the flower and fruit and seed, especially the early stages, so as to establish the homologies of the adult structures on which the classification is based. It was also intended, so far as possible, to study in the field the functional significance of the floral and fruit characters used in the classification.

- Part of this programme has been achieved. Dr. Styles has germinated in Oxford the seed of representatives of most genera and has studied the seedlings. With Dr. C. Vosa (197I, and in preparation), he has made a survey of the chromosome cytology. These results are incorporated in the present study.

Much work, however, remains to be done before a comprehensive synthesis can be presented. Work has recently been resumed on the study of differentiation and development. Field studies on floral and fruit biology are planned for the near future. Since the completion of this work cannot be expected in less than three or four years it has been decided to publish this generic monograph as it stands. We believe that its publication should stimulate local floristic studies from which further syntheses could be derived.

\section{PART I. GENERAL DISCUSSION}

\section{TAXONOMIC HISTORY}

The first edition of Species Plantarum ( 1753 ) contains two representatives of the Meliaceae, Melia azedarach L. and Azadirachta indica A. Juss., which Linnaeus named Melia azadirachta. He placed Melia in the Decandria Monogynia. The generic name Melia for purposes of valid publication (Article 13 Note 3 of the International Code of Botanical Nomenclature, 1972) is associated with the subsequent description given in the 5 th edition of Genera Plantarum (I754), although it had previously been described by Linnaeus in Hortus Cliffortianus (I 737) and in the first edition of Genera Plantarum (I737).

A number of genera which belong to the Meliaceae were described before the publication of Species Plantarum, but were not accounted for by Linnaeus. They were all described by Rumphius in his Herbarium Amboinense ( $174 \mathrm{I}-7$ ). This work contained descriptions and illustrations of species of six genera: Camunium (= Aglaia Lour.), Lansium, Sandoricum, Alliaria (= Dysoxylum BI.), Granatum (= Xylocarpus Koen.) and Surenus (= Toona M. J. Roem.). Although none of Rumphius' names are valid, they are important as two of them (Lansium and Sandoricum) were taken up by later authors, and the plates of some of the others serve to typify later descriptions (XYlocarpus).

During the 50 years subsequent to the publication of Species Plantarum, a number of well-known genera were described by Linnaeus and other authors. In 1756 in his Natural History of Jamaica, Patrick Browne described 4 new genera, Cedrela, Trichilia, Barbilus, and Elutheria. Because Browne used polynomials instead of binomials for some of his species, all his specific names are invalid, but this practice does not invalidate his generic names, and two of them, Cedrela and Trichilia, have continued in use to the present day. 
Barbilus is synonymous with Trichilia and Elutheria is now known to be the same as Guarea Allam. ex L. (177I), which is conserved against it.

The first species of Cedrela and Trichilia to be validly published, were included by Linnaeus in the tenth edition of Systema Naturae (1759), in which, besides describing the type species of Cedrela (C. odorata), Linnaeus also described C. mahagoni, but this plant, the true Mahogany, was transferred to Swietenia in the following year by Jacquin in his Enumeratio Systematica Plantarum Caribaeis. The well-known and widely distributed pantropical genus Turraea was not described until I77I, when Linnaeus included it in his Mantissa Plantarum. In I78I a small South African tree, Aitonia, which has often been placed in the Meliaceae, although until recently its position has been controversial, was described by Thunberg in Physiographiska Sälskapets Handlingar. This name is antedated, however, by Aytonia J. R. \& G. Forster, a liverwort genus in the Marchantiaceae. The slight difference in spelling is immaterial, since both names commemorate the same person. Aitonia of Thunberg is now known by its later synonym, Nymania of Lindberg (1868). In 1775 Aublet, in his Histoire des Plantes de la Guiane Française, described the Crabwood (Carapa) from French Guiana. Four years later the Swedish botanist Sparrman described Ekebergia from South Africa. In I784 Koenig (Der Naturforscher 20: 3), gave a description of Xylocarpus which is based partly on the plates named Granatum in Rumphius' Herbarium Amboinense, and in 1789 Cavanilles first validly published another Rumphian name, Sandoricum in his seventh Dissertatio Botanica. In the same work Cavanilles described the genus Quivisia which is now combined with Turraea. Loureiro described the first species of Aglaia, the largest genus in the family, in his Flora Cochinchinensis (I790), and in I807 Correa de Serra first validly published the closely related genus Lansium in his Vues Carpologiques (Ann. Mus. Hist. Nat. Paris Io : 157 ).

The Meliaceae received a circumscription similar to that accepted at the present time in the Prodromus Systematis Naturalis of A. P. de Candolle in 1824, although at that time only one quarter of the genera were known. However, many authors previous to de Candolle detected the essential similarity of certain genera which belong to this group. Linnaeus himself, in a series of lectures given to his students in 1771 and published as the Praelectiones in Ordines Naturales Plantarum by one of his students, Giseke, in 1792, indicated that Melia, Trichilia, Guarea, and Turraea are closely related, and he used this group of genera to form the basis of the Ordo 23, Trihilatae, although he also included in it eleven other genera which do not belong to the Meliaceae.

Rather more Meliaceous genera were brought together into a distinct family called Melieae by Anton Laurent de Jussieu in his Genera Plantarum (1789). It contained sixteen genera of which ten are true Meliaceae. These are Aitonia, Quivisia, Turraea, Sandoricum, Portesia (= Trichilia), Elkaja (= Trichilia), Guarea, Ekebergia, and Melia. The remainder, Canella, Symphonia, Tinus, Geruma, Ticorea, and Aquilicia belong to other families. It is interesting to observe that all ten belong to the subfamily Melioideae. The two genera of the subfamily Swietenioideae at that time known to science, Swietenia and Cedrela, are placed by de Jussieu at the end of the family as 'genera affinia'. De Jussieu placed the Melieae between the orders Aurantia (les Orangers) and Vites (les Vignes).

Earlier in the same year, Cavanilles, in his seventh Dissertatio Botanica, recognized a group containing fourteen monadelphous genera, of which seven belong to the Meliaceae. These are Sandoricum, Turraea, Melia, Swietenia, Guarea, Quivisia, and Portesia. It is interesting to note that Swietenia is included in this group, presumably because of its staminal tube, whereas Cedrela which lacks a staminal tube is not mentioned. At this time the authors of natural systems of classification were giving undue weight to the staminal tube, and this accounts for the inclusion in the Meliaceae of a number of genera which show this feature, but in other respects are very different from the Meliaceae. 
Ventenat in Tableau du Règne Végétal (I799) was the first to use the name Meliaceae; his interpretation of the family included only eight genera: Canella, Aitonia, Turraea, Sandoricum, Melia, Aquilicia, and, as related genera, Swietenia and Cedrela. Of these, Canella (Canellaceae) and Aquilicia (Leeaceae) are non-Meliaceous.

De Candolle in his Prodromus (1824) clearly reveals a more detailed knowledge of the relationships of the genera of the Meliaceae than all other previous authors. Six genera included in the family by de Jussieu are removed: Canella, Symphonia (Guttiferae), Tinus (Ericaceae), Aytonia, Ticorea (Rutaceae), and Aquilicia, one of them, Aitonia, mistakenly. Only three non-Meliaceous genera, Geruma (Aizoaceae), Humiria (Humiriaceae), and Strigilia (Styracaceae) are included in the family in this account.

De Candolle was the first to attempt to divide the family into tribes, which he based primarily on the number and structure of the seeds, as follows:

Tribe I. Melieae, characterized by fruit with $\mathbf{I}$ or 2 seeds per loculus, and unwinged albuminous seeds with an inverted embryo and foliaceous cotyledons, contains Geruma, Humiria, Turraea, Quivisia, Strigilia, Sandoricum, and Melia.

Tribe 2. Trichilieae, which includes Trichilia, Ekebergia, Guarea, and Heynea, is characterized by fruit with $\mathrm{r}$ or 2 seeds per loculus, exalbuminous unwinged seeds and an inverted embryo with thick cotyledons.

Tribe 3. Cedreleae, which includes Cedrela, Swietenia, Chloroxylon, Flindersia, and Carapa, is characterized by having many winged seeds per loculus, with a small amount of fleshy albumen, and an erect embryo with foliaceous cotyledons.

Since the publication of the Prodromus, our knowledge of the family has increased enormously, but these three groupings can still be detected in all modern classifications, though naturally they have been somewhat modified. Authors have differed in their opinions as to the relationships of Chloroxylon and Flindersia with the Meliaceae; their position is discussed more fully in a later chapter.

A still more detailed account of the Meliaceae was published in 1830 by Adrien de Jussieu. ${ }^{1}$ This thorough and painstaking work remained in use for a very long time. De Jussieu's classification which is based on a larger number of characters than any previous one, is a definite improvement. The characters used, in order of their importance, are:

I. Presence or absence of endosperm.

2. The ratio between the number of loculi in the ovary and the number of other parts of the flower.

3. Direction of the radicle relative to the hilum.

4. The situation of the anthers inside or on top of the staminal tube.

5. The form of the disk.

In circumscribing the family, A. de Jussieu returned to the practice of some earlier authors in excluding Cedrela, Swietenia, and Carapa, which he placed in a separate family Cedrelaceae, also containing Chloroxylon and Flindersia, and the new genera Khaya, Soymida, and Chukrasia. He excluded the two anomalous genera Humiria and Strigilia included in the family in the Prodromus and divided the family into two tribes.

Tribe I. Melieae, characterized by an endospermous seed, contained the new genera: Calodryum (now united with Turraea), Azadirachta (separated from Melia), and Mallea (= Cipadessa).

1. Mém. Mus. Hist. Nat. Paris 19, ?1830: 153-304; although it is dated as ' 1830 ', there is some evidence Guillemin, Bull. Sc. Nat. Geol.23, Nov. 1830: 234) that this did not appear until later, possibly I831. As Guillemin gives 2 verbatim report of de Jussieu's classification together with the diagnoses of his new genera and species we do not feel that he intended to publish the new names there. We are therefore attributing the new taxa solely to de Jussieu and continue to cite the 'Mémoire' as the original place of their publication. 
Tribe 2. Trichilieae, characterized by an exendospermous seed, also contains two new genera, Cabralea and Synoum.

During the first half of the nineteenth century, a number of botanical works, dealing with the floras of restricted geographical regions, were published, particularly for parts of Asia, in which genera of the Meliaceae were mentioned. The Meliaceae are well represented in India, and the first account for this country was by Roxburgh. A list of plants published in his Hortus Bengalensis (1814) included the names Heynea, Walsura, and Andersonia. Heynea was properly described and illustrated by Sims in the following year (Curtis' Bot. Mag. 4I), and Andersonia was described and illustrated under the new name Amoora by Roxburgh himself, in his Plants of the Coast of Coromandel (I820). Walsura was given a full description in the second edition of Roxburgh's Flora Indica (I832).

Blume (1825) gave an important account of the family in Bijdragen tot de Flora van Nederlandsch Indië, in which he described seven new genera, Aphanamixis, Chisocheton, Cipadessa, Dysoxylum, and three new genera which are now regarded as synonyms of Dysoxylum, viz. Didymocheton, Goniocheton, and Epicharis.

The first herbaceous genus of Meliaceae to be discovered, Naregamia, was described by Wight and Arnott in their Prodromus Florae Peninsulae Indiae Orientalis (1834), and five years later Wight described and illustrated a plant of similar habit, Munronia, in his Icones Plantarum Indiae Orientalis. About this time Ecklon and Zeyher described Ptaeroxylon from South Africa (Enum. Fl. Afr. Austr. Extratrop. I, 1834-35?: 54). This genus has often been placed in the Meliaceae but its exact relationships were doubtful. Following the studies of Leroy (1959, 1960a) and White and Styles (1966), it is now placed with the Malagasy genus Cedrelopsis in a separate family, the Ptaeroxylaceae. This is discussed more fully in a later chapter.

In $1846 \mathrm{M}$. J. Roemer published an account of the family in the first of his Synopses Monographicae, Hesperides. He followed A. de Jussieu in maintaining the Meliaceae and Cedrelaceae as distinct families. Fifty two genera were included in the Meliaceae, a great increase on earlier works; a few of these represented new genera, but the majority are generic splits not taken up by subsequent authors, except for one, Toona. The genus Oxleya (= Flindersia), included by Roemer in Cedrelaceae, is now placed in Flindersiaceae (Airy Shaw, 1966) or Rutaceae (Hartley, 1969).

The younger Hooker, in the Genera Plantarum of Bentham and Hooker (1862), followed A. de Candolle but differed from A. de Jussieu in uniting the Cedrelaceae and Meliaceae. All authors since then have done the same. Hooker included thirty seven genera in the Meliaceae, and all of them are fully and accurately described. Some of the genera he recognized have since been split into two or more and others have been subordinated to synonymy, but the majority are still accepted today. These genera are arranged in tribes as follows:

Tribe I. Melieae, characterized by united filaments, biovulate loculi, unwinged albuminous seeds, and plano-convex or foliaceous cotyledons, contains Quivisia, Calodryum (= Turraea), Turraea, Vavaea, Naregamia, Munronia, Melia (including Azadirachta), and Mallea (= Cipadessa).

Tribe 2. Trichilieae, characterized by united flaments, $\mathbf{r}$ - or 2 -ovulate loculi, unwinged exalbuminous seeds with thick, often fused, cotyledons, contains Dysoxylum, Chisocheton, Epicharis (= Dysoxylum), Cabralea, Sandoricum, Aglaia, Milnea (= Aglaia), Lansium, Amoora (= Aglaia), Synoum, Guarea, Dasycoleum (= Chisocheton), Ekebergia, Walsura, Heynea, Beddomea (= Aglaia), Moschoxylon (= Trichilia), Odontandra (= Trichilia), Trichilia, Owenia, Carapa (including Xylocarpus). 
Tribe 3. Swietenieae, characterized by united filaments, multiovulate loculi, fruit a septifragal capsule, many seeds with or without albumen and often winged. Swietenia, Khaya, Soymida, Chukrasia ("Chickrassia'), Elutheria (= Schmardaea).

Tribe 4. Cedreleae, characterized by free stamens, multiovulate loculi, fruit a septifragal or loculicidal capsule containing many compressed seeds, contains Cedrela, Chloroxylon, and Flindersia.

Aitonia was placed at the end of the family among 'genera affinia aut exclusa', with the comment 'ad Sapindaceas pertinet'.

In addition to a number of genera now regarded as synonyms, a considerable number have been described during the last one hundred years. The African genus Turraeanthus was described by Baillon in 1874 , who in the same year published an account of the family in his Histoire des Plantes. This account was based largely on that of the younger Hooker, but contained unorthodox views on synonymy. He rightly included Calodryum under Turraea, but mistakenly combined Vavaea under Quivisia, Walsura under Heynea, Ruagea under Guarea, and Dysoxylum under Epicharis.

Four years later (1878), Casimir de Candolle, in Monographiae Phanerogamarum, resurrected Vavaea and Walsura, but reduced Aphanamixis to Amoora. C. de Candolle's circumscription of Dysoxylum included Didymocheton and Epicharis, Guarea included Ruagea, Carapa included Xylocarpus, and Cedrela included Toona.

In 1884 Hemsley raised to generic rank the endemic Sinhalese tree Dysoxylum championii Hook. $f$. \& Thoms ex Thw. and called it Pseudocarapa; three years later he described an interesting Malayan endemic genus, Megaphyllaea. In I893 Baillon described from Madagascar Quivisianthe papinae, a species which is very isolated and whose relationships are still uncertain today. A small genus, Reinwardtiodendron, related to Aglaia and Lansium, was described by Koorders in 1898 from Celebes.

In I 896 Harms published his first account of the Meliaceae in Engler and Prantl's Die Natürlichen Pflanzenfamilien. In this work he described 4 new genera, Lovoa, Pseudocedrela, Pterorhachis, and Symphytosiphon (= Trichilia), and included the recently described Entandrophragma of C. de Candolle. Beddomea, which had been maintained by C. de Candolle, was included under Aglaia by Harms, who also combined Quivisia with Turraea, Heynea with Walsura, and Epicharis and Didymocheton with Dysoxylum. Aphanamixis was again reinstated as a genus in this work, as were Xylocarpus and Toona.

In the same year as the publication of Harms' account of the Meliaceae, Pierre described the New Caledonian genus Anthocarapa, based on two species which C. de Candolle had placed in Amoora, and in 1897 he described the West African genus Heckeldora.

An interesting South African shrub, Nurmonia, which was until 1968 known only from the type gathering, was described by Harms in 19I7. It is now considered to be synonymous with Turraea. Urbanoguarea was described by the same author in 1937.

In I940 Harms published a revised account of the Meliaceae for the second edition of Die Natïrlichen Pflanzenfamilien in which several taxa given sectional rank in the first edition were elevated to generic status. These are Heynea, Ruagea, Didymocheton, and Epicharis.

Since the publication of this important work, further genera have been described. Verdcourt (1956) described Pseudobersama, a monotypic African genus related to Trichilia, based on a plant originally placed in Bersama (Melianthaceae). Leroy, more recently, working on the rich and little known Malagasy flora, has described 6 endemic genera: Neobeguea, Calodecaryia, Capuronianthus, Malleastrum, Astrotrichilia, and Humbertioturraea, and one, Lepidotrichilia, which occurs both in Madagascar and East Africa.

Other noteworthy taxonomic works of recent years (mainly revisions of genera or 
sections of genera) include those of Pellegrin (1939) on Guarea, Earle Smith (1960) on Cedrela, and Kostermans (1966) on Lansium.

Since the publication of Bentham and Hooker's Genera Plantarum, four comprehensive classifications of the family have been published - Casimir de Candolle (1878), two by Harms ( 1896 and 1940 ), and one based on the anatomy of the secondary xylem by Kribs (1930). This last classification is discussed in Chapter 4.

The classification of C. de Candolle ( 1878 ) is closely similar to that of the younger Hooker. He divided the family into four tribes as follows:

Tribe. I. Melieae, contained those genera included by J. D. Hooker, except Vavaea which was removed to the Trichilieae. The recently described Turraeanthus was placed in the Melieae because its flowers bear a superficial resemblance to Turraea. At that time its fruit was unknown.

Tribe 2. Trichilieae, has the same circumscription as that of Hooker, except that Carapa was removed to the Swietenieae.

Tribe 3. Swietenieae, is that of Hooker, plus Carapa.

Tribe 4. Cedreleae, is the same as that of Hooker.

Harms' first account of the Meliaceae (I896) is also similar to those of Hooker and C. de Candolle but contains some important differences. Harms divided the Meliaceae into three subfamilies in the following way:

Subfamily I. Cedreloideae. This contains Cedrela and Toona and, in a separate tribe, Ptaeroxylon. Flindersia and Chloroxylon are excluded from the family.

Subfamily II. Swietenioideae, has the same content as C. de Candolle's Swietenieae, except that Carapa and Xylocarpus are removed.

Subfamily III. Melioideae, is subdivided into six tribes, the first of which, Carapeae, contains Carapa and Xylocarpus. The remaining five tribes account for all genera of C. de Candolle's Melieae and Trichilieae, plus those new genera subsequently described.

Aitonia (Nymania), which is again included by Harms in the family, is placed in the Turraeeae.

The contents of the tribes are as follows:

Tribe I. Carapeae : Carapa, Xylocarpus.

Tribe 2. Turraeeae : Cipadessa, Aitonia, Munronia, Turraea, Naregamia, Pterorhachis.

Tribe 3. Vavaeeae : Vavaea.

Tribe 4. Melieae : Melia.

Tribe 5. Azadirachtieae: Azadirachta.

Tribe 6. Trichilieae : Megaphyllaea, Sandoricum, Dysoxylum, Cabralea, Turraeanthus, Chisocheton, Lansium, Aphanamixis, Amoora, Pseudocarapa, Synoum, Aglaia, Guarea, Owenia, Walsura, Ekebergia, Odontandra (= Trichilia), Trichilia, Symphytosiphon (= Trichilia).

In the second edition of Die Natürlichen Pflanzenfamilien, Harms (I940) did not alter the circumscription of the subfamilies, except to include those genera described since I896. His division of the Melioideae into tribes remained virtually unchanged, except that Azadirachta was included with Melia in the tribe Melieae, so reducing the number of tribes to five.

During the present century, and increasingly in recent years, much information on the anatomy, structure of the pollen grain, and the chemistry of the group has been published. The taxonomic significance of characters of the secondary xylem and of pollen grain structure is discussed in later chapters. Although our knowledge of the chemistry of the Meliaceae and related families is rapidly increasing (see, for instance, Bevan et al., I962, D. A. H. Taylor, I965, and many other references cited in Grijpma and Styles, Biblio- 
grafía selectiva sobre Meliáceas, 1973) insufficient is known at present for the taxonomic value of chemical characteristics to be fully evaluated. Because of this, the chemistry of the group is not considered further.

More recently still, Styles and Vosa (1971), Styles and Khosla (in press), and Mehra et al. (1972) have published chromosome counts for most genera. Until further work is done, however, on those genera with a large number of species, the taxonomic value of this information cannot be fully assessed. Chromosome numbers are given under each relevant genus.

\section{MORPHOLOGY}

Almost all the species of Meliaceae are woody; the majority are trees, ranging from forest giants down to small treelets. In tropical Mexico and Central America they are often abundant in the upper storey of the high evergreen forest, e.g. Swietenia. In Africa the dominant high forest emergents, Khaya, Entandrophragma, and Lovoa are very important as producers of quality timber. In Malesia they form an important component of the understorey of the lowland forests, e.g. Chisocheton, Aglaia. Some members of a few genera, e.g. Turraea, are shrubs, whilst Naregamia and Munronia are small suffrutices with a woody rootstock.

The habit is often useful for field identification. Small unbranched trees with a dense terminal cluster of large pinnate leaves ('Schopfbaum') are commonly found in several genera, e.g. Chisocheton; the leaves may be as much as three metres in length and are especially large in juvenile specimens. Other species are medium or large trees with littlebranched pachycaulous twigs, as seen in Entandrophragma; the internodes are very short and the leaves produced in a dense terminal cluster, a habit easily recognizable at a distance in the field. One genus (Vavaea) has sympodial ('Terminalia') branching.

The bark configuration does not appear to be very significant at the subfamily, tribe, or generic levels; smooth, scaly, and dippled types are present in most of the larger genera. Bark characters are probably more useful at the species level.

The extent to which a milky exudate in the bark occurs in the family is uncertain, but our observations in South East Asia, Africa, and tropical America indicate that it is often characteristic of genera. Aglaia is always seen to have a certain amount of such exudate, although it may be small in quantity and slow to appear, whereas in Chisocheton and Dysoxylum a milky exudate is never present. The bark frequently emits an objectionable smell when crushed or cut, for example of onions in many species of Dysoxylum, or of garlic (Cedrela, Toona); the odour of the bark of some species of Aglaia in New Guinea and the Solomon Islands causes nausea and the sap is also very caustic. The wood of these species is not used commercially for this reason.

The buds of all species of the subfamily Swietenioideae are surrounded by a cluster of small subulate scales. This feature has not been observed in any species of the other subfamilies where the buds are naked.

The leaves are nearly always spirally inserted and very often clustered near the branch tips; they are constantly decussate only in Capuronianthus mahafalensis J. F. Leroy of the subfamily Capuronianthoideae; decussate leaves also occur very rarely in Dysoxylum and Turraea but the arrangement is usually inconstant and varies from opposite to spiral.

The majority of species have pinnate leaves. In Melia they are bipinnate. Bipinnate leaves also occur in juvenile specimens of Chukrasia and Lovoa. Those of Sandoricum are trifoliolate. Several of the genera with pinnate leaves contain species which are trifoliolate or unifoliolate. The latter differ from simple leaves by the presence of the conspicuous 
pulvinus at the insertion of the leaflet as in species of Aglaia and Walsura. A small number of genera have simple leaves (Turraea, Nymania, Calodecaryia, Vavaea). A terminal leaflet is usually present in the majority of genera with pinnate leaves, but this is not constant in occurrence and may be present or absent within a single species (Toona ciliata M. J. Roem.) Rarely it is much reduced to a vestige (some species of Cabralea and Carapa). In Amoora cucullata Roxb. it is reduced in size and converted into an hooded structure. Occasionally a genus has exclusively paripinnate leaves, e.g. Owenia and Pseudocarapa.

Chisocheton, Megaphyllaea, and Guarea are characterized by pinnate leaves which show intermittent apical growth. At the leaf apex of these genera is a small curled bud (like the apex of a fern frond). This bud has intermittent growth and produces leaflets at intervals for several years (up to II years' growth measured in Guarea rhopalocarpa Radlk. from Costa Rica, cf. Skutch, I946). Although the mature leaflets of these species are opposite, each member of a pair may develop separately. As new leaflets are produced at the leaf apex, so the older leaflets are shed from the basal portion of the rhachis. Finally the rhachis itself is shed. The leaf behaves like a shoot and has certain anatomical structures of one, e.g. a closed cambial ring. The compound leaves of many tropical plant families have a similar structure, but that of Guarea rhopalocarpa Radlk. differs in its greater thickness and in the presence of annual rings, together with the production of a corky bark. Some species of other genera, e.g. Cabralea and Dysoxylum, show a limited amount of apical growth, with the basal leaflets maturing before the apical ones, but there is no distinct terminal bud showing alternating periods of growth and dormancy. Growth is continuous, usually ending in the formation of a terminal leaflet.

Occasionally, the rhachis of a compound leaf is flattened and winglike as in Pterorhachis and Naregamia.

The leaflets are usually entire, less frequently dentate, serrate, or crenate, and very rarely with a prickly margin (a few species of Trichilia, e.g. T. cuneifolia (L.) Urb.).

Secretory cells of various shapes and sizes are found throughout the Meliaceae, usually at the boundary between the spongy and palisade mesophyll in the leaves (Metcalfe and Chalk, 1950: 351). In some genera these are visible as transparent lines or dots as in Cabralea. In some species of Trichilia, Walsura, and Ekebergia the cells of the lower leaf epidermis are produced into numerous papillae which give the undersurface a very characteristic glaucous appearance.

The indumentum is sometimes diagnostic of a genus, e.g. Aglaia is characterized by stellate hairs or peltate scales. There is no sharp distinction between these two types of indumentum and they may merge with one another within a single species. Munronia has a curious mixture of simple hairs with bifid or stellate hairs. This has not been observed elsewhere in the Meliaceae.

The inflorescence is very variable but is generally some form of panicle or thyrse. Within Aglaia alone this can vary from a large inflorescence, one-third to two-thirds of a metre long with profuse branching and an abundance of flowers, to a much reduced minute inflorescence $1-2 \mathrm{~cm}$ long. In many genera the ultimate ramifications of the inflorescence are cymose (thyrse), e.g. Melia, Cedrela, and Entandrophragma. Many genera of the Melioideae appear to be dioecious, although undoubtedly some species produce both hermaphrodite and of flowers (polygamous) on the same plant. In Melia the terminal flowers of the branchlets are hermaphrodite and the lateral ones male (Lee, 1967). All the genera of Swietenioideae appear to be monoecious (Styles, 1972). In Cedrela and Toona and probably all other genera of Swietenioideae the terminal flower of a cymule is female while the other two are male.

Sex differences in inflorescence structure are often marked in the subfamily Melioideae. 
Generally, male inflorescences are longer and more profusely-branched than the female. In some species of Aglaia, while the male inflorescence is $20-50 \mathrm{~cm}$ long and manyflowered, that of the female may be reduced to a spike $2-3 \mathrm{~cm}$ long with less than ten flowers.

In Chisocheton and Guarea the panicle branches are often greatly reduced in length and the main axis elongated. The resulting thyrsoid inflorescence may be up to a metre long, as in Chisocheton penduliflorus Planch. ex Hiern. Rarely the main axis of the inflorescence is reduced in length and branched from near the base to form a compound thyrse (Pterorhachis). In a few species of Trichilia and Turraea the inflorescence is fasciculate. Aphanamixis is characterized by a spicate female inflorescence, whilst the male inflorescence is usually paniculate with spicate branches. Both male and female inflorescences of this genus may be up to a metre long. Naregamia and Nymania have solitary or paired flowers.

The inflorescence is generally axillary, less frequently terminal. It is often borne above the axil of a leaf (supra-axillary) as in Chisocheton and Aphanamixis. Cauliflory and ramiflory occur sporadically throughout the subfamily Melioideae, e.g. in species of Dysoxylum and Chisocheton. Lansium domesticum Corr. has the inflorescence borne upon the branches. In older cauliflorous trees, the flowers are borne on large warty bulges on the trunk.

Flower size and shape vary within wide limits, from the minute globular flowers of Aglaia $0.05 \mathrm{~cm}$ in diameter to the long tubular flowers of Turraea over $10 \mathrm{~cm}$ in length. The Swietenioideae are characterized by having (in general) small flowers. In monoecious or dioecious species the male flowers are generally smaller and much more numerous than the female. The shape of the flower is characteristic for most genera, e.g. globular in Aglaia, tubular in Chisocheton. Although the flowers are usually inconspicuous in colour, being dull white, greenish-white, or pale yellow, they frequently emit a powerful scent. This is particularly noticeable in Aglaia. Other Malesian genera are also scented, though the odour varies considerably in quality and power.

Calyx form is variable and frequently important at the generic level. Free or almost free imbricate sepals are present in only a few genera, e.g. Ruagea and Cabralea. Munronia and a few species of Turraea have a deeply divided calyx with open aestivation and the lobes are distinctly foliaceous. The number of lobes varies from (2) 4 or $5(7)$. In several genera, notably part of Turraea, Chisocheton, Sandoricum, and Guarea, there occurs a calyx with the margin only very shallowly toothed or entire (truncate). A few species of Guarea, Chisocheton, Dysoxylum, and Megaphyllaea have a calyx which is entirely closed in bud and is circumscissile. In Megaphyllaea and some Chisocheton species the calyx is greatly thickened in the lower half and round the middle there is a swollen and warty band.

A single whorl of (3) 4 or $5\left(-\mathrm{I}_{4}\right)$ free petals greatly exceeding the calyx in length is the rule in the family. Gamopetalous corollas with the petals united to halfway or more occur sporadically (e.g. some species of Trichilia), but petals fused at the base are fairly frequent in Aglaia and a few other genera. Megaphyllaea is unique in having a biseriate corolla (petals 8-io in 2 whorls, fused in the lower half). In several genera, e.g. Munronia, Turraeanthus, and part of Dysoxylum, the petals are free from each other, but are fused to halfway or higher with the staminal tube. In a few species of Munronia the petals adhere to the staminal tube in the young flower, but appear to become free as it matures. In Cedrela and Toona the petals are adnate to the androgynophore by a median flap of tissue (carina), which prevents them spreading in open flowers. The aestivation is generally imbricate, usually one-fifth ('cochleardachig'), but two-fifths in some species of Aglaia. Contorted aestivation is frequent in the subfamily Swietenioideae and occasional elsewhere. Valvate aestivation occurs in several genera, e.g. Guarea, Chisocheton, Cipadessa, Malleastrum, and Xylocarpus. Aestivation of the corolla is a rather unreliable character for 
classification as it is sometimes variable even within a single specimen. The mature petals usually reflex, especially in those species with tubular flowers, this providing a useful character for field recognition. The shape of the petals varies widely from almost orbicular in Aglaia and Aphanamixis to linear or spathulate in those genera with tubular flowers (e.g. Dysoxylum, Turraea). The petals of the Meliaceae are often rather thick and fleshy (e.g. Chisocheton, Dysoxylum).

The androecium provides more characters of diagnostic importance in the classification of Meliaceae than any other structure. The characteristic feature of the family is the partial or complete fusion of the filaments to form a staminal tube. Only two genera (Cedrela, Toona) have consistently free filaments. A few species of Trichilia and Walsura have free filaments but in these they are flattened dorsoventrally, giving the impression of a complete staminal tube in the mature flower. Genera with filaments united only in the lower half are Cipadessa, Calodecaryia, Nymania, and some species of Entandrophragma. In other genera there may be great variation in the degree of fusion, as in Trichilia, which has the complete range from free filaments to a complete staminal tube. The degree of fusion may even vary within a single species, as between male and female flowers of Trichilia havanensis Jacq. However, the degree of fusion of filaments is constant within genera in certain parts of the family as in Dysoxylum and Chisocheton, which are characterized by a complete staminal tube.

The shape of the androecium ranges from globular with a minute apical pore or cupshaped as in Aglaia, to a long narrowly-cylindrical tube as in Turraea and Dysoxylum. In Naregamia and some species of Turraea the cylindrical tube is inflated at the apex.

The apex of the filaments or the margin of the staminal tube often bears filiform, lanceolate, deltate, truncate, emarginate, or bilobed appendages. In those species with a complete staminal tube, the appendages usually alternate with the anthers (or antherodes in female flowers) and equal them in number, whereas those with only partial fusion of the filaments usually have two or rarely 3-io times as many appendages as anthers. The anthers are usually double the number of the petals, most commonly 8- $\mathrm{IO}$, but in Aglaia the petals and anthers are often equal in number $(s)$ and rarely reduced to only 3 . Rarely the number of anthers is very large (up to 23 in Chisocheton macranthus (Merr.) Airy-Shaw).

The anthers may be hairy or glabrous but this character is rarely constant within a genus and often varies within single species (Vavaea amicorum Benth.). The anther connective is frequently produced to form a short or sometimes long terminal appendage as in Naregamia. In Schmardaea it is much produced and thread-like. In nearly all species of Chisocheton and in Megaphyllaea the anthers differ from those of other Meliaceae in having transverse septa (locellate). This gives the young anthers a segmented appearance before dehiscence.

The position of insertion of the anthers in the staminal tube is often a character of generic value. The anthers may be inserted apically at the end of the filaments or on the margin of the staminal tube as in Trichilia, or inside the throat of the staminal tube with the anthers completely included or only partially exserted as in Dysoxylum. Although the insertion is constant for the majority of genera, in a number of instances it varies within a genus, for example in Aglaia and Owenia.

Various structures collectively known as disks occur between the base of the ovary and the staminal tube. These are often brightly coloured and sticky and probably function as nectaries. In a number of genera, e.g. Aglaia, Aphanamixis, and Lansium, a disk is absent, and in Chukrasia and Schmardaea it is indistinct. In Guarea and some species of Chisocheton the ovary is borne on top of a short or long stipe structure (stipitate disk.) In Cedrela and 
Toona both ovary and stamens are supported on a columnar or swollen disk-like stipe or androgynophore which is partially fused to the inner face of the petals. In many species of the tribe Trichilieae (subfamily Melioideae) the disk is represented by a narrow ring of tissue surrounding the base of the ovary (annular disk). In other cases it may be a poorly developed saucer-shaped structure (patelliform disk) either free from, or fused to the base of the staminal tube or to the base of the ovary. In some species of Trichilia the patelliform disk is not only fused to the lower part of the staminal tube but is also deeply ribbed (androecial ribs). The disk reaches its greatest development in Dysoxylum, Cabralea, Sandoricum, and some species of Munronia where it is represented by a cup-shaped (cyathiform) or long tubular structure with an entire or toothed margin, often enclosing the ovary and part of the style. In most genera of the Swietenioideae the disk is prominent and well-developed and is often lobed or ridged.

The ovary is usually superior, but in Sandoricum, Aphanamixis, and Cabralea it may be partly sunken. The number of loculi varies from I-20, but is usually $2-5$. Malleastrum, which sometimes has a unilocular ovary, appears to be unilocular by abortion; the one extant loculus is markedly eccentric. The number of ovules in each locule provides an important subfamily distinction. Each locule may contain one or two collateral or superposed ovules (nearly all Melioideae) or 3- many biseriate ovules (Swietenioideae). Rarely the locules contain 2 well-developed ovules and I or 2 vestigial ovules as in Capuronianthus and Guarea thompsonii Sprague \& Hutch. The anatropous or orthotropous ovules are attached to an axile placenta or very rarely to a parietal placenta (Heckeldora).

In Aglaia and Aphanamixis and several other genera with small flowers, the style is very short or absent. In those genera with tubular flowers it is usually long and slender ( $D y$ soxylum). In Sandoricum the style is very stout and columnar. The style-head shows great variation in form and provides valuable characters for classification. In some of the genera with very small flowers, e.g. Aglaia, it is like a very small pin-head (capitate). In Aphanamixis it is expanded into a conical structure, and in most genera of the Swietenioideae it is flattened and discoid, often with a central depression and stigmatic ridges. It frequently blocks the entrance to the staminal tube. The style-head is occasionally pileate (shaped like a mushroom) as in some species of Walsura. In Melia, Azadirachta, and Sandoricum the expanded style-head bears several large stigmatic lobes. The style-head reaches its greatest development in Turraea where it is often modified to form a variouslyshaped receptaculum pollinis, surmounted by a small apical stigmatic area. Observation of the living plant shows that pollen is shed on to the style-head before the flower opens (White and Styles, 1963).

Sexual dimorphism within flowers of many genera in the Meliaceae has been fully discussed by Styles (1972).

The fruit shows wide variation in size and structure and is often a conspicuous feature in the field. The bright orange or red capsules of Trichilia and Dysoxylum, which stand out against the background of dark green foliage, contrast with the dull greyish-brown berries of Aglaia or Lansium. The fruit is most frequently a capsule, either septifragal (Swietenioideae, Capuronianthoideae) or loculicidal (Quivisianthoideae, Melioideae). The septifragal capsules of the Swietenioideae are usually woody and generally contain a central columella which is angled or ridged (rudimentary in Schmardaea, Xylocarpus, and Carapa) and to which the seeds are attached. Dehiscence of this type of capsule may be basal, apical, or from base and apex simultaneously. The loculicidal capsules of the Melioideae do not have the central columella and may be woody, leathery, membraneous, or even fleshy. Dehiscence of the loculicidal capsule is always from the apex. The capsule rarely bears simple or branched appendages; in Pseudobersama these are stout and antler-like, whereas 
in some species of Trichilia they are slender and fimbriate. Dehiscence may be slow, and difficult to observe in dried herbarium material (especially in some species of Guarea and Chisocheton). Sutures are not always visible and dehiscence may occur only after the fruit has been shed. Capuronianthus is unusual in that its endocarp dehisces regularly along the septa whereas the epi-mesocarp dehisces irregularly or not at all. Further field observations are needed in many cases to determine mode and time of dehiscence.

Indehiscent fruits are also widespread in the Melioideae. Soft berries occur in Aglaia, Lansium, Malleastrum, etc., whereas in Owenia and Astrotrichilia the fruit is drupaceous. Although the distinction between a berry and drupe is not sharp, those genera with drupaceous fruits always show some differentiation of the endocarp, though this may be only a thin cartilaginous layer, as in some species of Lepidotrichilia and Sandoricum. In Owenia and Astrotrichilia the endocarp is thick and woody. One undescribed species of Aglaia has an indehiscent fruit in which the pericarp is entirely dry and woody (nut). In Heckeldora the berry is constricted between the seeds and also rostrate.

Seeds in the Meliaceae are of two principal types. The first has a thin dry testa and a conspicuous dry wing, which may be terminal or occur all the way round or at both ends. Seeds with terminal wings are attached to the placenta or columella either by the wingor seed-end. This type of seed is characteristic of subfamilies Swietenioideae and Quivision-

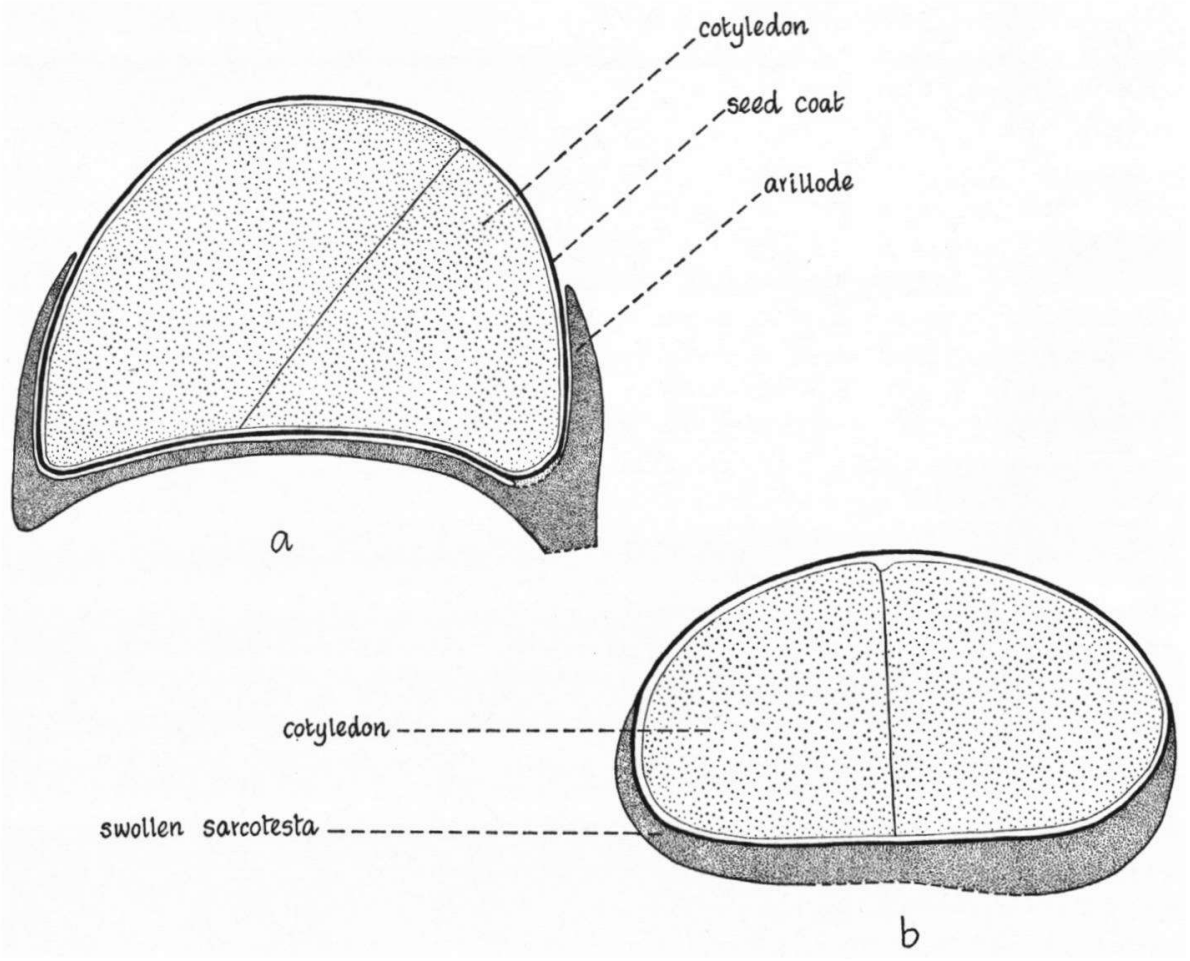

Fig. I. a. Aphanamixis grandifolia Blume, T. S. of seed, showing arillode forming a free flap of tissue, attached to seed only along a line joining micropyle-raphe-chalaza. - b. Guarea excelsa H.B.K., L.S. of seed, with fleshy sarcotesta appearing as a localized swelling of the seed coat. 
thoideae. Unwinged seeds, usually with a fleshy arillode or sarcotesta, are typical of the Melioideae. Studies of the arillode and sarcotesta may indicate that there is no fundamental morphological difference between them. They both appear to arise from localized or generalized meristematic activity in the outer integument. Meristematic activity may extend back to the funicle or occasionally as far as the placental tissue (Turraea), but as it is never confined to these areas but always includes part of the seed coat between the raphe and the micropyle, it is thought inadvisable to use the restricted term aril for this structure. In this work the fleshy outgrowth is called an arillode if it forms a partially or completely free flap of tissue surrounding a part or the whole of the seed (fig. Ia) and a sarcotesta when the fleshy part appears as a localized or general swelling of the seed coat (fig. Ib). There is no sharp distinction between the two, and they both occur within a single genus. (e.g. Trichilia).

The structure of the arillode or sarcotesta is sometimes sufficiently modified to be useful as a diagnostic generic character. Synoum is unique in having a fleshy arillode which unites the two seeds of a valve along the abaxial surface. The sarcotesta of Munronia covers the adaxial surface of the seed and before maturity the fleshy inner cells disintegrate, leaving the ripe seed with a large, hollow, membraneous structure. A similar condition occurs in Nymania. The sarcotesta of Ruagea is attached to the basal (chalazal) portion of the seed and is greatly swollen. The colour of the arillode or sarcotesta is related to dehiscence of the fruit. In species with dehiscent fruit, where the arillode or sarcotesta act as visual attractants for birds or mammals, they are red or orange, often contrasting with the black undifferentiated part of the seed coat. In species with indehiscent fruit, where they cannot act by visual attraction, they are always white or colourless.

Genera of the Turraeeae (Melioideae) are characterized by the presence of endosperm, often quite copious. Elsewhere in the family it occurs sporadically (in species of Trichilia and Astrotrichilia) and is often very thin and rather difficult to observe (Vavaea and several genera in the Swietenioideae). The shape and structure of the embryo are correlated with the presence or absence of endosperm. Those genera with endosperm usually have thin embryos with flat collateral cotyledons and a long exserted superior radicle. Those without endosperm have larger embryos with plano-convex cotyledons and included radicle. The position of the cotyledons and radicle is usually constant within genera, e.g. Aglaia has superposed cotyledons and an included radicle, Guarea usually has an abaxial radicle. Most frequently the radicle is placed at the apex of the seed (superior).

\section{WOOD STRUCTURE}

Because of the great economic importance of many genera of Meliaceae to the timber industry, their wood anatomy has been extensively studied. Moll and Janssonius (1908), Kribs (1930), Panshin (1933), and Dadswell and Ellis (1939) have discussed the characters of the secondary xylem of the Meliaceae in relation to taxonomy, but only Kribs studied the whole family and attempted to produce an anatomical classification with a key to the genera.

In his investigation, Kribs examined II2 species from 36 genera. At the time this was probably the most comprehensive anatomical investigation ever carried out on a family of tropical plants of comparable size. It is significant for several reasons. First, he constructed a key to 36 genera of the Meliaceae, based entirely on characters of the secondary xylem and thus implied that all 36 genera could be keyed out using only anatomical characters. Second, on the basis of this knowledge, supplemented by facts from gross morphology which he obtained mainly from the literature, he suggested a new arrange- 
ment of genera which differed from those of previous authors. His conclusions were as follows:

I. Cedrela (including Toona) should be transferred to the subfamily Swietenioideae.

2. Carapa and Xylocarpus should also be placed in the subfamily Swietenioideae.

3. Lovoa should be placed in a subfamily of its own, the Lovoinoideae.

4. The genera Flindersia, Chloroxylon, and Ptaeroxylon resemble the Rutaceae more closely than the Meliaceae in their wood structure.

5. The Swietenioideae is the only subfamily which forms a homogeneous group in respect of gross morphology and wood structure. Because of this he reverts to the opinion of A. de Jussieu and M. J. Roemer that it should rank as a family, to be known as the Swieteniaceae.

It was clear from the start of the present study that many of the genera recognized by previous authors and dealt with by Kribs, especially those in the subfamily Melioideae, were very closely related, so that it was necessary to view his claims with caution. Kribs used only a small sample of species in each genus, and he did not discuss the variability of the characters.

It was our intention to study as wide a range of species as possible from all genera, to test the constancy of characters, and, for selected species, to use as many samples as possible to examine the variation of characters within species. 370 slides representing about 230 species were examined during this study. $85 \%$ of the slides were correlated with herbarium specimens. At least one slide of each species was photographed in transverse, tangential, and radial section. The collection of photographs is deposited in the Forest Herbarium, Department of Forestry, University of Oxford.

In Part II will be found descriptions of the secondary xylem of the Melioideae and, where this is of some taxonomic interest, it is discussed more fully in the commentary following each genus. All genera are described except Calodecaryia, Sphaerosacme, Heckeldora, and Quivisianthe for which no material was available, and for Naregamia and Munronia which have insufficient secondary xylem for meaningful comparisons to be made. The genera in Swietenioideae have been fully dealt with in the Forest Products Research Bulletin No. 25, Identification of Hardwoods ( 1960$)$, and that information is not repeated here. New information has been added under the relevant genus.

The terms used to describe vessels, fibres, and parenchyma are defined in the International Glossary of Terms used in Wood Anatomy, Anon. (1957), and those used to describe ray tissue follow Kribs (1950).

The main conclusions concerning Kribs' work can be summarized as follows:

\section{CIRCUMSCRIPTION OF THE FAMILY}

In Chapter 5 the relationships of Cedrelopsis, Ptaeroxylon, Flindersia, and Chloroxylon with the Meliaceae are discussed in greater detail. Kribs only examined the last three genera, and concluded that they were more Rutaceous than Meliaceous. We have found that although the wood of Ptaeroxylon is definitely not Meliaceous, it is similar to that of species of both the Rutaceae and Sapindaceae; and the wood of Flindersia and Chloroxylon, in their secondary xylem, have more features in common with the Rutaceae than with the Meliaceae, but do share features of both and cannot be referred definitely to either on the basis of wood anatomy alone. 


\section{CIRCUMSCRIPTION OF THE SUBFAMIIIES}

This is discussed in detail in Chapter 5 , but the role of the secondary xylem in circumscribing the subfamilies may conveniently be summarized here. We agree with Kribs that on the basis of the structure of their secondary xylem, Cedrela and Toona, Carapa and Xylocarpus should be placed in the Swietenioideae. The following combination of characters defines this subfamily: rays nearly always broad, (2) $3-6(7)$-seriate, and heterogeneous; crystals usually present in the marginal ray cells, often absent from wood parenchyma; paratracheal parenchyma rather sparse (vasicentric or aliform); terminal wood parenchyma in regular to irregular concentric lines (frequently absent in Khaya); fibres septate (non-septate in Neobeguea).

Kribs suggested that Lovoa should be placed in a subfamily of its own, due to its anomalous wood structure which lacks the heterogeneous rays and crystals in the marginal ray cells. However, he ignored the fact that Lovoa possesses all the characteristic morphological and palynological features of the Swietenioideae, as well as some of its anatomical features. If Lovoa is removed from the Swietenioideae, then Turraeanthus, Cipadessa, and Sandoricum could equally justifiably be removed from the Melioideae where on all other grounds they clearly belong. Isolating such genera on account of their anomalous wood anatomy is an impractical solution which creates more problems than it solves. Lovoa clearly belongs in the Swietenioideae, and there is little justification for removing it.

In the present work, the recently discovered Malagasy genus Capuronianthus is placed in a subfamily of its own, the Capuronianthoideae. It is intermediate in many morphological features between the Melioideae and Swietenioideae, and wood anatomical characters support this decision as they are also intermediate between the two subfamilies. The secondary xylem of this genus has crystals in both marginal ray cells and wood parenchyma, and 2 or 3-seriate rays which are partially heterogeneous.

\section{VARIATION WITHIN SPECIES AND GENERA}

Kribs did not discuss variation of the secondary xylem within species or genera. Some other authors who have studied the wood anatomy of species of Meliaceae from restricted geographical regions have done so.

Moll and Janssonius (I908) investigated the anatomy of several South East Asian genera, and state that variation within species often exceeds that between species, especially in Aglaia. We have examined infra-specific variation in three species: Trichilia hirta $\mathrm{L}$. (six samples from the West Indies and Central America), Dysoxylum caulostachyum Miq. (six samples from New Guinea, New Britain, and the Solomon Islands), Aphanamixis grandifolia Bl. (I3 samples from Malaya, Sarawak, Sabah, New Guinea, and New Britain). This has shown that certain characters previously believed to be of value in defining genera can vary within a single species, viz. (I) the amount of paratracheal and apotracheal parenchyma can vary within wide limits; (2) apotracheal parenchyma is not always constant in occurrence and may be present or absent within the same species.

Variation between species of the same genus is frequently greater than that between species of different genera. In Aglaia there is great variation in the amount of paratracheal parenchyma; it varies from sparse vasicentric and aliform (e.g. $A$. argentea Bl.) to almost exclusively banded (e.g. A. shawiana Merr.). These differences are greater than those between $A$. shawiana Merr. and Lansium domesticum Corr.

There appears to have been some convergence in secondary xylem characters of different genera occurring in the same geographical region. Within Madagascar the secondary 
xylem of several species of Turraea, Malleastrum, and Lepidotrichilia is closely similar. It is characterized by vessels in groups of 2 or 3 with scattered distribution, and sparse vasicentric and aliform paratracheal parenchyma, and conspicuous bands of terminal apotracheal parenchyma. In contrast, certain Turraea species in East Africa may differ in all these features. T. robusta Gürke has vessels arranged in conspicuous tangential bands, aliform and confluent parenchyma, and apotracheal terminal bands are very few or absent.

\section{THE DISTINCTNESS OF THB GBNERA IN THEIR SECONDARY XYLEM}

It was found that within the subfamily Melioideae only nine of the genera treated by Kribs are distinct on characters of their wood anatomy alone. A further four, not examined by him, are also distinct. These are Nymania, Melia, Azadirachta, Vavaea, Pseudobersama, Ekebergia, Astrotrichilia, Owenia, Cipadessa, Aphanamixis, Tumaeanthus, Megaphyllaea, Sandoricum. All of these except Pseudobersama are easily separable on morphological grounds.

Kribs' key was based on insufficient observations. Inspection of a wider range of species shows that his generic characters are not constant and frequently break down. Three characters which he uses at the generic level in this group are found to be variable within genera: homogeneous versus heterogeneous ray tissue; presence of crystals in the wood parenchyma; presence of apotracheal versus diffuse parenchyma.

The subfamily Swietenioideae forms a distinct homogeneous group and none of the genera can be satisfactorily distinguished on characters of their wood anatomy alone. Even in Lovoa which, as already mentioned, was placed by Kribs in its own subfamily, all of the anomalous anatomical characters attributed to it by him are shared by other genera in the subfamily and are not diagnostic: viz. absence of terminal parenchyma is shared with Khaya, homogeneous rays with some species of Entandrophragma and with Chukrasia, and non-septate fibres with Neobeguea and some specimens of Chukrasia. Kribs' observation that the secondary xylem of Cedrela is ring porous is based on insufficient samples as all gradations between ring and diffuse porous conditions exist. On the basis of wood anatomy Carapa and Xylocarpus belong here. Furthermore there is no single feature which adequately distinguishes the secondary xylem of Carapa from that of Swietenia.

\section{CONCLUSIONS}

(I) The secondary xylem provides good characters for the delimitation of the subfamilies.

(2) Within the subfamily Melioideae, two correlated anatomical characters are important (when correlated with morphological and palynological features) in arranging the genera in tribes:

(a) non-septate fibres usually with terminal bands of apotracheal parenchyma - Turraeeae, Melieae, Trichilieae (except Cipadessa), Sandoriceae.

(b) septate fibres usually without terminal bands of apotracheal parenchyma Vavaeeae, Aglaieae, Guareeae (except Turraeanthus).

The presence or absence of fibre septa is very constant within genera; only two exceptions have been recorded (one sample in Vavaea and one in Astrotrichilia).

(3) In the Meliaceae only a few genera can be distinguished on their wood anatomy alone. They are distinct on morphological grounds.

(4) In a few cases the secondary xylem provides additional evidence for maintaining 
otherwise doubtfully distinct genera, e.g. Pseudobersama, Aphanamixis, and Ruagea. In Anthocarapa the secondary xylem helps to indicate the relationships of a genus of doubtful position.

\section{POLLEN}

The only previous comparative account of the pollen morphology of the Meliaceae is that of Erdtman in Pollen Morphology and Plant Taxonomy (1952, 1966). His account of the family is based on personal observation of twenty seven species from eighteen genera, and he cites twenty one species together with the voucher herbarium specimens from which the slides were prepared.

Although Erdtman's account is based on only a small sample of the family, he had also studied related families in a similar way. On the basis of these limited observations, he was able to draw the conclusion that pollen morphology does not support Harms' suggestion that the three subfamilies should rank as families. Otherwise he follows Harms' (1940) arrangement of the family, including such anomalous genera as Ptaeroxylon and Cedrelopsis which clearly do not belong. He concludes that the Meliaceae is a more or less stenopalynous family.

After a preliminary study of about thirty species representing a cross-section of the family, it appeared that the pollen morphology of the family was not very variable, except for Ptaeroxylon and several species of Turraea. These latter were so different from the rest that it appeared that their characteristics might be of taxonomic value. As the pollen grains of the majority of genera in the family had never been examined, it was decided to study a selection from every genus. During the course of this investigation we have examined the pollen of two hundred species from all genera of the family except Megaphyllaea. For the larger genera such as Aglaia and Trichilia, we have examined up to twenty species of each, and in others which showed a large range of variation, all variable species were examined. In addition we have seen a selection of about fifty slides from related families (Rutaceae, Sapindaceae, Burseraceae, Simaroubaceae, and Anacardiaceae) which were kindly loaned to us by the late Professor Erdtman. Formal descriptions of the pollen characteristics of the family and genera are incorporated in Part II, and where pollen is of some taxonomic value this is discussed fully in the commentary following each genus.

The palynological terms used here are principally from Erdtman (1952, 1966). The terms describing exine patterning are also from Erdtman, except that the term 'scabrous' is used to indicate a condition intermediate between 'smooth' and 'verrucose' in which the minute protuberances are less than I $\mu \mathrm{m}$ high. The sizes of grains refer to the longest axis and represent the value or range of values most frequently found in the sample examined. The pollen slides were prepared by the well-known acetolysis method.

Some general conclusions on the taxonomic value of pollen morphology in this group are given here.

\section{CIRCUMSCRIPTION OF THE FAMIIY}

On the grounds of pollen morphology Flindersia and Chloroxylon belong to the Rutaceae, and should definitely not be included in the Meliaceae. The pollen grains of Cedrelopsis and Ptaeroxylon which are closely similar, differ in several important respects from the pollen grains of all known Meliaceae. They resemble the grains of some species of Rutaceae, though not closely. The relationships of these four anomalous genera are discussed in greater detail in Chapter 5. 
At the beginning of this study, the taxonomic positions of Nymania and Pterorhachis were also doubtful. Nymania had frequently been excluded from the Meliaceae by previous authors, and Pterorhachis superficially resembles several Sapindaceous genera. The pollen grain structure of both genera confirms that they are correctly placed in the Meliaceae. Fuller details are given in the commentary following the formal descriptions of these genera.

\section{CIRCUMSCRIPTION OF THE SUBFAMILIES}

There are no significant differences in pollen structure between the subfamilies. The subprolate or prolate-spheroidal 4-colporate grain with a smooth exine is constant in the Swietenioideae (including Cedrela, Carapa, and Xylocarpus). For this reason it is not discussed further in Part II. This type of grain is also frequently found in the other three subfamilies, but in the Melioideae there are also a number of other types. Several genera, e.g. Vavaea, Aglaia, and Lansium are characterized by prolate or prolate-spheroidal 3-colporate grains; most species of Guarea and Dysoxylum have spheroidal 4-colporate grains, and the genera of the Turraeeae are characterized by oblate or oblate-spheroidal 3 -colporate grains with a verrucose exine.

\section{CIRCUMSCRIPTION OF THE TRIBES}

For morphological reasons we conclude that Pterorhachis and Cipadessa do not belong in the Turraeeae (subfamily Melioideae) where they were placed by Harms (1940). Pollen grain morphology confirms that both these genera should be excluded from this tribe. The pollen of the Turraeeae, with these two genera excluded, differs from that of the remainder of the Melioideae in several well-correlated characters. Its grains are almost consistently oblate or oblate-spheroidal, 3-colporate, with a prominently scabrous or verrucose exine, a combination of characters rarely encountered elsewhere in the family. A preliminary examination of a few species of Turraea ( $T$. cornucopia White \& Styles ined. and $T$. vogelii Hook. $f$. ex. Benth.) revealed pollen grains so extreme that we thought the genus might be wrongly placed in the Meliaceae. However, further study of a greater range of species showed that others were less extreme (e.g. T. abyssinica Hochst. ex A. Rich. and T. robusta Gürke), and the pollen of the related genus Munronia is intermediate between typical Turraeeae and the remainder of the Melioideae. The pollen grains of Munronia are usually 4-colporate, though they retain the other distinctive features of the Turraeeae. The Turraea-type pollen has been found very rarely elsewhere in the Melioideae (e.g. in Trichilia surumuensis C. DC. from British Guiana).

\section{RELATIONSHIPS OF THE GENERA}

With few exceptions, pollen characteristics are of limited value in identifying genera in the Melioideae. Occasionally pairs or groups of genera are characterized by distinctive grains (e.g. Aglaia, Lansium, Reinwardtiodendron, with very small, usually 3-colporate, prolate grains). In one case the pollen grain structure provides additional evidence for reinstating a genus given only sectional rank by Harms (Heckeldora), and in three further examples (Nymania, Pseudocarapa, and Anthocarapa), pollen structure in combination with morphological characters helps to indicate the true relationships of genera. 


\section{DELIMITATION OF THE TAXA}

There has been some degree of agreement among the different specialists who have worked on the group as to the circumscription of the Meliaceae, its subfamilies, tribes, and genera, but previous accounts are far from unanimous so that at the beginning of this investigation there were a number of taxonomic problems urgently requiring attention. In addition, since the publication of the latest comprehensive treatment (Harms, 1940), eight new genera have been described, and their positions within the family needed to be established.

With the aid of herbarium specimens borrowed from the major herbaria of the world and with many collections gathered during our own extensive fieldwork in tropical America, Africa, and South East Asia, we have been able to assemble complete material of some 300 species of Meliaceae, about 200 of which have correlated wood samples. Our taxonomic conclusions are based largely on the detailed examination of this morphologically complete material. Although this certainly represents more material than previous workers have used, it still only covers about half the total number of species suspected to occur in the family. We have also examined incomplete material of a further 50 species and this has not revealed any characters which extend the limits of variation recorded for each genus.

We have examined the pollen of 200 species, and as a result of this investigation have found that the characters of the pollen grain are chiefly of value in circumscribing the family, and in one case (Turraeeae) in delimiting a tribe, but for the most part, the differences between genera are very slight.

Our investigations of the secondary xylem revealed that it is of greater taxonomic value than the pollen grain. The secondary xylem is useful in delimiting the family and subfamilies, and to a lesser extent the tribes, and in a number of cases the genera. Separate chapters have already been devoted to a general discussion of pollen and wood structure, but further information concerning their use in solving the major taxonomic problems is given below.

By means of a critical study of all the data assembled, it has been possible to define the genera of the Meliaceae more clearly than before, and to produce improved generic keys. It is necessary to circumscribe the family, subfamilies, and tribes somewhat differently from Harms. In Part II, the gross morphology, pollen grain, and wood anatomy of the family are fully described. Keys to and formal descriptions of the genera are given with detailed discussions on the relationships, where relevant. In Part II most of our views on the taxonomy of the genera are recorded, but the more important taxonomic decisions are discussed at greater length below.

\section{THE NUMBER OF FAMILIES INVOLVED}

Should the Meliaceae be split into two or three separate families? A. H. L. de Jussieu (I830) recognizes Meliaceae and Cedrelaceae, and Harms (1940), although treating the Meliaceae as a single family, suggests that his three subfamilies, Cedreloideae, Swietenioideae, and Melioideae could equally well be treated as separate families.

There is little morphological, anatomical, or palynological evidence to support this suggestion. From the discussion below, it can be seen that the best division of the Meliaceae is into four subfamilies, but these do not deserve family rank. The Meliaceae fall naturally into two large subfamilies (Melioideae and Swietenioideae) which are clearly distinguished by several well-correlated morphological and anatomical characters, but the limits between these two groups are confused by the Malagasy genera Quivisianthe and Capu- 
ronianthus. These share some of the characteristics of both Melioideae and Swietenioideae, but are nevertheless sufficiently isolated from them and from each other to be given subfamily rank (Quivisianthoideae, Capuronianthoideae). Further discussion of these two remarkable genera is given below.

\section{CIRCUMSCRIPTION OF THE FAMILY}

\section{a. The taxonomic position of Flindersia and Chloroxylon}

Was Harms ( 1896,1940 ) correct in excluding them from the Meliaceae, where they had been frequently included by previous authors (De Candolle, I824; Hooker $f$., I862; C. de Candolle, 1878)? Although both these genera lack some of the important characters of the Meliaceae, e.g. the staminal tube, they do share other morphological and anatomical features with both Meliaceae and Rutaceae. Engler (1877) referred them to the Rutaceae on account of the presence of schizogenous secretory cavities in the leaf. Secretory cells, which are found in the leaf tissue of all Meliaceae, are absent from the leaf of Flindersia and Chloroxylon, but present in the cortical tissue of the axis, so in this respect they appear to be intermediate between the Meliaceae and Rutaceae. Morphological evidence is conflicting. Both genera lack the characteristic staminal tube of the Meliaceae, and the filaments are not flattened at the base. The leaves of Flindersia are frequently opposite, a character hardly ever found in the Meliaceae. On the other hand, Flindersia has a septifragal capsule like that of many Swietenioideae, although it is warty or prickly, a feature never found in this subfamily.

The wood structure of Flindersia has been studied in great detail by Harrar (1937) who concluded that although it was more closely related to the Rutaceae than to the Meliaceae, the anatomical evidence did not point clearly to either, as it possesses some characters of both families. The colour and scent of the wood is typical of Rutaceae except for $F$. brayleana F. Muell. which resembles that of the Meliaceae. The large, multiseriate, homogeneous rays in combination with non-septate fibres are known in only four genera of Meliaceae, whereas they are frequently present in the Rutaceae. In contrast, $F$. collina F. M. Bail. has heterogeneous rays with crystals in the marginal cells which are present in all Meliaceae subfamily Swietenioideae. Harrar therefore favoured the formation of a distinct family, the Flindersiaceae. C. T. White (193I), who was familiar with the morphological features of the genus, had already reached a similar conclusion.

The secondary xylem of Chloroxylon also possesses features of both Meliaceae and Rutaceae. The individual characters of the wood of Chloroxylon are frequently found in the Meliaceae, but the combination of vessel type and pattern, storied rays, non-septate fibres, and sparse paratracheal parenchyma are rarely seen. The secondary xylem of Pseudocedrela kotschyi (Schweinf.) Harms is the most similar, differing only in the larger vessels and partially septate fibres. In the Rutaceae, Esenbeckia leiocarpa Engl. is very close, differing only in the absence of terminal banded parenchyma and chambered crystalliferous parenchyma. After examining the wood of many genera of the Rutaceae, we conclude that the features of Chloroxylon are more commonly found in that family than in the Meliaceae, but there is not sufficient evidence either way to place this genus using characters of the secondary xylem alone.

Erdtman (1952, 1966) noted that the pollen grains of Flindersia and Chloroxylon are similar to those of the Rutaceae. Our observations confirm this opinion, as no species of Meliaceae seen by us has 3-colporate grains in combination with a rather small polar area and a reticulate or prominently scabrate exine. 
According to Price (1952) and Ritchie et al. (1963), there is strong phytochemical evidence for placing Flindersia and Chloroxylon in the Rutaceae. Both contain coumarin and the alkaloids known as furoquinolines which are absent from the Meliaceae. In the light of this evidence, Hartley in his recent monograph (1969) had no hesitation in placing Flindersia in the Rutaceae.

The above facts confirm that Harms was correct in excluding these two genera from the Meliaceae.

\section{b. The taxonomic position of Ptaeroxylon and Cedrelopsis}

Ptaeroxylon has usually been placed in either the Sapindaceae or Meliaceae. As long ago as 1860 Sonder, in Flora Capensis, gave it family rank and placed it after the Sapindaceae, though expressing doubt as to its true affinity. Hooker (1862) and many subsequent authors, have put it in the Sapindaceae. Radlkofer (I890) transferred it to the Meliaceae, where Harms (1896, 1940) allowed it to remain. Mauritzon (1936) has shown that the ovule structure of Ptaeroxylon is very similar to that of Sapindus, while Jenkin (196r) found that the secondary xylem of Ptaeroxylon was closely similar to that of Amyris (Rutaceae). Ptaeroxylon lacks the staminal tube of the Meliaceae and the filaments are not flattened at the base; the capsule does contain a central columella but this differs significantly from that of the capsule in Cedrela and genera of the Swietenioideae. It does, however, possess some of the features of the Meliaceae, e.g. the intra-staminal disk. Recently Leroy (1959, 1960a) has discussed the relationships of Ptaeroxylon and Cedrelopsis and concluded that they should constitute a separate family, close to the Sapindaceae.

From our own observations we conclude that Ptaeroxylon has a combination of anatomical features unknown in the Meliaceae. These are minute vessels in long radial multiples; short, uniseriate, homogeneous rays; presence of diffuse crystalliferous parenchyma and apotracheal terminal bands only; fibres with few septa. Examination of the entire collection of slides of the Sapindaceae and Rutaceae at the Department of Forestry, University of Oxford, indicates that, although there is a close similarity between the secondary xylem of Ptaeroxylon and that of Amyris, the features shown by these two genera are unusual in the Rutaceae. On the other hand, although the exact combination of characters could not be found in genera of the Sapindaceae, the wood of Ptaeroxylon has many features in common with this family. Uniseriate homogenous rays, partially septate fibres, and very scarce paratracheal parenchyma are all frequently found in the Sapindaceae.

The Malagasy genus Cedrelopsis is closely related to Ptaeroxylon and very similar to it in morphology and in the structure of the secondary xylem. Leroy (I960b) has shown that there are greater differences between the wood of different species of Cedrelopsis than between Cedrelopsis and Ptaeroxylon.

Ptaeroxylon and Cedrelopsis also have very similar pollen morphology, the grains of both having a reticulate exine quite unlike that of any known Meliaceous pollen grain, but similar to that of some Rutaceae (e.g. Calodendrum).

This shows that although Ptaeroxylon and Cedrelopsis definitely do not belong in the Meliaceae, there is not sufficient evidence for placing them in either the Sapindaceae or Rutaceae. The most satisfactory solution is therefore to treat them as a separate family, the Ptaeroxylaceae. White and Styles (1963), who give a full account of the genus Ptaeroxylon, have confirmed Leroy's views on this. 


\section{c. The taxonomic position of Nymania}

Nymania had formerly been placed in several other families, especially the Sapindaceae, because its external appearance is so unlike that of most other Meliaceae. The leaves are linear and sclerophyllous, the fruit is an inflated capsule, and the filaments are fused at the base and scarcely flattened. A detailed examination of its morphology, wood anatomy, and especially pollen, shows that it is closely related to Turraea and Calodecaryia in the subfamily Melioideae. A full discussion of its relationships is given after the generic description in Part II.

\section{d. The taxonomic position of Pterorhachis}

This genus is also superficially rather distinct from all other Meliaceae and resembles many Sapindaceae. The pollen structure had not been previously studied, but Heimsch (1942), who examined the secondary xylem, included it in the Meliaceae without commenting on its relationships. Any resemblance between Pterorhachis and the Sapindaceae is, however, entirely superficial, and a critical examination of morphology, wood, and pollen, shows that it definitely belongs in the Meliaceae and is closely related to Trichilia.

\section{THE NUMBER AND CIRCUMSCRIPTION OF THE SUBFAMIIIES}

De Candolle (1824) divides the Meliaceae into three tribes: Melieae, Trichilieae, and Cedreleae, the latter containing Cedrela, Swietenia, and Carapa (including Xylocarpus). The younger Hooker (1862) divides the family into four tribes: Melieae, Trichilieae which contains Carapa (including Xylocarpus), Swietenieae, and Cedreleae containing Cedrela (including Toona). C. de Candolle (1878) follows Hooker's system but removes Carapa (including $X y l o c a r p u s$ ) and places it in the Swietenieae. Kribs (1930), in an investigation of the wood structure, concludes that the Meliaceae should be divided into three subfamilies: the Swietenioideae, including Carapa, Xylocarpus, Cedrela, and Toona; the Lovoinoideae, including Lovoa; the Melioideae. Harms (1896, 1940) splits the Meliaceae into three subfamilies:

I) Cedreloideae (including Cedrela and Toona);

2) Swietenioideae;

3) Melioideae (including Carapa and Xylocarpus).

Clearly, the correct circumscription of these groups of genera is uncertain, and in particular there is great divergence of opinion as to the relationships of Cedrela and Toona, and Carapa and Xylocarpus with the rest of the family. Their status as separate genera is discussed in Part II.

\section{a. The relationships of Cedrela and Toona}

When Ptaeroxylon and Cedrelopsis are excluded from the family, Harms' first subfamily, the Cedreloideae, contains only Cedrela and Toona, and these differ from the genera of Harms' second subfamily, the Swietenioideae, in only one feature: their filaments are free, whereas those of the Swietenioideae are united. The other important morphological characters of the Swietenioideae, the multiovulate loculi and septifragal capsule, are also shared by Cedrela and Toona. The wood structure of the Swietenioideae is homogeneous, and that of Cedrela and Toona agrees with it in all important respects. It is characterized by broad heterogeneous rays, large crystals in the marginal cells of the rays, by the absence of crystals in chambered parenchyma cells, and by sparse paratracheal parenchyma. The 
pollen grains of the Swietenioideae are almost uniform, being 4-colporate, prolate, with a smooth exine. Those of Cedrela and Toona are identical with these in all important respects.

In our opinion the single morphological difference of Cedrela and Toona from the Swietenioideae does not warrant their separation from this subfamily, and they would be better included in it. The morphological difference between Cedrela and Toona and the Swietenioideae, the degree of union of the filaments, is variable within large genera of the family, e.g. Trichilia and Entandrophragma, but it must be pointed out that the filaments of Cedrela and Toona are in fact not flattened, and are fused to the disk in a manner not occurring elsewhere in the family.

\section{b. The relationships of Carapa and Xylocarpus}

Harms places Carapa and Xylocarpus in the Melioideae because they lack the dry winged seeds of the Swietenioideae and because the number of ovules in the loculus of Carapa is fewer than that of other genera of the Swietenioideae, though in general always more than two.

In our opinion Harms was mistaken in placing Carapa and Xylocarpus in Melioideae. By doing so, the distinction between two well-defined groups becomes confused. Apart from the seed character, Carapa and Xylocarpus agree in all important respects with Swietenioideae. The loculi are normally multiovulate (Harms did not realize that the flowers of these genera are unisexual and possibly based some of his observations on the 'ovary' of male flowers, which often contain fewer, abortive, ovules than the female). Furthermore, the fruit is a septifragal capsule with an, albeit rudimentary, columella. Carapa and Xylocarpus possess all the characteristic secondary xylem features as well as those of the pollen grain, of the Swietenioideae.

There are also strong biological grounds for including these two genera in Swietenioideae. The shoot borer (Hypsipyla spp.) which attacks most genera in this subfamily also attacks Xylocarpus and Carapa. This suggests that the group shares a group of similar biochemical compounds to which the insect is attracted. Genera in Melioideae are on the other hand not attacked.

These facts show clearly that Carapa and Xylocarpus were wrongly placed in the Melioideae and should be transferred to the Swietenioideae. With Cedrela, Toona, Carapa, and Xylocarpus in the Swietenioideae, the distinctions between the two major subfamilies become much clearer. They are summarized later in Part II.

\section{c. The position of Capuronianthus}

Leroy (1958a) who described the genus, placed it in a new subfamily the Carapoideae together with Carapa and Xylocarpus. Although admitting that Capuronianthus is extremely distinct from all known genera of Meliaceae, he considered it possesses all the essential characteristics of the Carapa-Xylocarpus pair. Minfray (1963, 1963a) supported this arrangement on cytological grounds, because both Carapa and Capuronianthus possess the same chromosome number, $2 \mathrm{n}=58$.

We believe, however, that there are strong reasons against a) placing Capuronianthus with Carapa and Xylocarpus in a separate subfamily and b) placing Capuronianthus in the Swietenioideae.

We have shown above that there is overwhelming evidence, both morphological and anatomical, for including Carapa and Xylocarpus in the Swietenioideae. The arguments 
against putting Capuronianthus in the Swietenioideae are equally strong. It shares with Carapa and Xylocarpus only two characters of any significance, viz. septifragal dehiscence of the capsule and the seed with a corky sarcotesta (XYlocarpus). It differs from them both in the following important characters: buds naked (protected by scales in Carapa, Xylocarpus, and all Swietenioideae); leaves decussate (spirally arranged in Carapa, Xylocarpus, and all Swietenioideae); loculi biovulate with one or two vestigial ovules (usually multiovulate in Carapa, Xylocarpus, and all other Swietenioideae); style-head capitate (discoid in Carapa, Xylocarpus, and nearly all Swietenioideae). The cytological data is inconclusive (Capuronianthus and Carapa $2 \mathrm{n}=58 ; X y$ locarpus $2 \mathrm{n}=52$ ). As Styles and Vosa (197I) point out, the Meliaceae has such a wide range of chromosome numbers that it is premature at this stage to draw any taxonomic conclusions from chromosome cytology.

Whilst acknowledging the distant relationship of Capuronianthus with Carapa and Xylocarpus, we consider that the only acceptable solution is to place this very distinct genus in a subfamily of its own, the Capuronianthoideae. This procedure emphasizes its great isolation and also preserves the unity of the Swietenioideae.

\section{d. The position of Quivisianthe}

Our knowledge of this exceptionally interesting genus from Madagascar is at present limited to a few herbarium specimens. In its floral structure it belongs in the Melioideae near Trichilia (where it was retained by Harms, 1940) or Ekebergia, though the androecium of five stamens is rarelv found. even in the Trichilieae. The fruit structure is, however, quite unique in the family, a dry loculicidal capsule, containing dry winged seeds. These distinctive fruit and seed characters, which have already been shown to be important at the subfamily level, indicate the great isolation and antiquity of Quivisianthe and we have no hesitation at this stage in placing this genus in its own subfamily, the Quivisianthoideae. Further anatomical, cytological, or chemical data may shed light on its relationships but on the basis of information available at present it does not appear to have any close relations in the family.

\section{THE NUMBER AND CONTENT OF THE TRIBES IN THE SUBFAMILY MELIOIDEAE}

In previous classifications there is a tendency for certain related genera always to occur close together, but, nevertheless, there is appreciable divergence of opinion as to the number of tribes and their exact content. In Harms' latest treatment of the family, his arrangement of the Melioideae is based, for the most part, on the progression of a few characters which he considered of great evolutionary importance: a) the position of insertion of the anthers in the staminal tube; b) the presence and form of the intra-staminal disk; c) the presence or absence of endosperm. Harms states that anthers inserted at the ends of the filaments or on the margin of the staminal tube, represents a primitive condition and that insertion within the throat of the tube is more advanced. Similarly he recognizes an evolutionary series in the form of the disk, from the small annular structure surrounding the base of the ovary (primitive) to a shallow cyathiform disk, and finally the most advanced form is the long tubular envelope surrounding the ovary and base of the style. Harms' arrangement of the tribe Trichilieae is partly based on these two series.

The character states of anther insertion and disk structure may well represent evolutionary series, but it appears that they have arisen independently several times in the Melioideae and they are not always correlated with other progressive trends. Because of 
the undue weighting of these characters, Harms' tribe Turraeeae contains genera that do not belong there (e.g. Cipadessa) and his subtribes of the Trichilieae contain artificial groups of genera. In order to obtain an improved grouping of these genera, we have subordinated the supposed evolutionary significance of individual characters in favour of a grouping based on the correlations between the maximum number of characters of use at this level of classification and on the detection of discontinuities in the variation pattern of these characters. By basing the classification on a large number of characters, the most natural grouping of the genera is obtained and artificial assemblages resulting from the weighting of a few characters are avoided. The major changes from Harms' arrangement of the Melioideae are detailed below.

Tribe I. Carapeae. This is excluded from the Melioideae for the reasons stated above.

Tribe 2. Turraeeae. As circumscribed by Harms this is heterogeneous because of the inclusion of Cipadessa and Pterorhachis. The former was included because of its endospermous seed, and the latter presumably because of the winged rhachis which it shares with Naregamia. In all other important morphological, anatomical, and palynological characters these genera are similar to various genera in the Trichilieae, where we have placed them.

Tribe 5. Trichilieae. Harms divided this into four subtribes, the contents of which are very heterogeneous.

Our new grouping of the genera, based on the principles outlined above, is summarized here. Subfamily Melioideae

Tribe I. Turraeeae: Munronia, Naregamia, Turraea, Humbertioturraea, Calodecaryia, Nymania.

Tribe 2. Melieae: Melia, Azadirachta.

Tribe 3. Vavaeeae: Vavaea.

Tribe 4. Trichilieae: Trichilia, Pseudobersama, Pterorhachis, Walsura, Lepidotrichilia, Malleastrum, Ekebergia, Astrotrichilia, Owenia, Cipadessa.

Tribe 5. Aglaieae: Aglaia, Lansium, Aphanamixis, Reinwardtiodendron, Sphaerosacme.

Tribe 6. Guareeae: Heckeldora, Cabralea, Ruagea, Turraeanthus, Guarea, Chisocheton, Megaphyllaea, Synoum, Anthocarapa, Pseudocarapa, Dysoxylum.

Tribe 7. Sandoriceae: Sandoricum.

The first three tribes correspond fairly well with those of Harms, except that Cipadessa and Pterorhachis have been removed from the Turraeeae, but his tribe Trichilieae has been subdivided into four groups, each of which is given tribal rank. Each of the above seven tribes contains a natural assemblage of genera, but the limits between the Trichilieae. Aglaieae, and Guareeae can only be defined by reference to a number of overlapping morphological, anatomical, and palynological characters. Diagnoses of each tribe are given in Part II.

\section{DELIMITATION OF THE GENERA AND THEIR RELATIONSHIPS}

An examination of Harms' generic key reveals that less than half the genera in the Melioideae appear to be distinct on the basis of the characters used. In some cases the genera are keyed out on overlapping characters so that discontinuities in the variation pattern are not revealed. Sometimes there is a verbal distinction expressed but no corresponding morphological distinction. Also, a number of genera are keyed out by reference to their geographical distribution, and Harms has not provided evidence that they are morphologically distinct.

Within recent years there has been considerable divergence of opinion as to the status 
of a number of entities in the family. For instance, Heynea, Amoora, Clemensia, Didymocheton, and Epicharis have been treated as genera by some workers and as taxa of lower rank by others.

Subsequent work to that of Harms has shown that some genera, e.g. Trichilia, are heterogeneous, partly because a number of species formerly included were known only from imperfect material. Leroy (I958b) raised the section Lepidotrichilia to generic rank and combined two others, Astrotrichilia and Peltotrichilia, to form the genus Astrotrichilia.

Chapter 2 (Morphology of the Group) shows that there is a very wide range of morphological variation within the family, especially in the subfamily Melioideae. Many of the structures vary independently and because of this, well-defined sets of characters which can be used to delimit genera clearly, are difficult to find. The variation appears to be so continuous and complicated that on superficial acquaintance it might be argued that well-defined genera scarcely exist, and that the majority of species should be merged into one huge genus. If this were done, the resulting entity would contain more variation than has ever before been allowed to exist in a single genus. At the other extreme, it would be possible to create a very large number of homogeneous genera, which are constant in most, if not all, important morphological characters. If this were done, the resulting number of genera would be enormous, and a large number of unacceptable name changes would be necessary. If such a procedure is adopted, problems arise as to which characters should be used to delimit the genera. Different people would choose different characters and instability would inevitably result as in, for instance, the Sapotaceae. It is both desirable and possible to take the middle course, but in some cases generic delimitation presents certain difficulties.

A few genera are isolated (Vavaea, Sandoricum), or form an isolated pair (Melia and Azadirachta). The other genera of the Melioideae fall into four tribes, Turraeeae, Trichilieae, Aglaieae, and Guareeae, which all show a similar variation pattern. The majority of species in each tribe fall into a single large genus (except the Guareeae, where there are three large genera) which, although it contains much variation, is still definable and because of its nature cannot be satisfactorily split. The remaining species of each tribe form a number of small satellite genera which are closely related to their respective large genera. In the Turraeeae, Turraea contains the majority of species and Humbertioturraea, Calodecaryia, and Nymania are small, closely related genera. In the Trichilieae, Trichilia accounts for the majority of species and Pterorhachis, Pseudobersama, Lepidotrichilia, Astrotrichilia, Walsura, Malleastrum, and Ekebergia are closely related satellites. Generally, the large genus possesses one or more constant features (e.g. the stellate or peltate indumentum of Aglaia) which is lacking in its satellite genera, and in addition, the satellites possess a number of differential characters not present in the large genus.

Most of the genera we recognize differ from all others in the family in at least two characters common to all species. In other cases there is a single feature so unusual that it can justifiably be used as a generic character, e.g. the biseriate corolla of Megaphyllaea. In such cases the genera defined in this way are not artificial, since the species they contain resemble each other more than they do any species in any other genus.

There are a small number of genera more difficult to define. This is because, although any species of a particular genus may differ from any species of another genus in several characters, none of the defining characters are absolutely diagnostic in the sense of White (1962), so that the genera are recognized on a number of differential characters only.

In some cases, as in separating Chisocheton and Guarea, only the combined variation of several differential characters shows a discontinuity and can therefore be used to define these genera. 
Applying these principles we have found it necessary to modify the treatment of Harms as follows:

(I) In the Trichilieae. Although we have some strong reservations, we agree with Bentvelzen (1962) that, on the basis of evidence presently available, Heynea should be reduced to Trichilia (see Part II, under the relationships of Trichilia). We have confirmed the conclusions reached by other authors that five of the sections of Harms' Trichilia should be removed from the genus. Although Hofmeyer (I925) transferred $T$. pterophylla C. DC., the type species of section Pterotrichilia, to Ekebergia, Harms (1940) allowed it to remain in Trichilia. The present work has shown this to be untenable.

We consider that Leroy (1958b) was fully justified in raising the section Lepidotrichilia to generic rank, and also in accommodating Harms' section Pterotorhachis within his recentlydescribed genus Malleastrum (1964). Leroy (1958c) was also right to combine Harms' sections Astrotrichilia and Peltotrichilia to form the new genus Astrotrichilia.

(2) In the Aglaieae. We consider that Amoora should be reduced to Aglaia. A species provisionally called Aglaia decandra by Wallich, which is included under Lansium by Harms, should be raised to generic rank and be known as Sphaerosacme.

(3) In the Guareeae. Harms' section Heckeldora of Guarea should be reinstated as a genus, as is done by Keay (r958). On the other hand, we have failed to find evidence which would justify maintaining Leplaea and Urbanoguarea as genera, as is done by Harms. They should be reduced to Guarea.

Airy-Shaw (1937) was justified in reducing Clemensia to Chisocheton. Harms maintains the genus Rhetinosperma provisionally near Chisocheton and Dysoxylum. It has since (L. S. Smith, I959) been reduced to Chisocheton, and although we have not had an opportunity of examining any material of this species, from the description of the plant it clearly belongs in this genus.

Harms (1940) maintains Didymocheton and Epicharis but we consider it is more satisfactory to include them under Dysoxylum.

In Part II the reasons for these changes are given in the discussion of the relationships of each genus.

\section{PART II. THE CONSPECTUS}

\section{MELIACEAE Vent.}

Meliaceae Vent., Tab. Règ. Vég. 3 (1799) I59-166; DC., Prod. I (1824) 6r9-626; A. Juss., Mém. Mus. Hist. Nat. Par. 19 (?1830) I 53-304; M. J. Roem., Synops. Monogr. Hesperid. I (1846) 76-1 Is; Hook. $f$. in Benth. \& Hook., Gen. Plant. I (1862) 327-340; Miq., Ann. Mus. Bot. Lugd. Bat. 4 (1868) I-64; C. DC., in A. \& C. DC., Monog. Phan. I (1878) 399-758; Harms, in Engl. \& Prantl, Nat. Pflanzenfam. 3. 4 (1896) 258-308; ed. 2, 19 bI (1940) 1-I72; Pennington, A taxonomic study of the Meliaceac; unpublished D. Phil. thesis pp. 234. Bodleian Library, Oxford, (1965).

Trees, treelets or shrubs, rarely with sympodial ('Terminalia') branching, rarely herbs with woody rootstocks. Bark sometimes with a milky exudate. Buds protected by a cluster of scale-leaves or naked. Leaves spirally arranged, very rarely decussate, usually pinnate, with or without a terminal leaflet, sometimes with a dormant terminal bud, less frequently simple, rarely trifoliolate or unifoliolate, very rarely bipinnate. Leaflets usually entire, rarely lobed, dentate, serrate, or crenate. Indumentum usually simple, less frequently of bifid or stellate hairs or of peltate scales. Inflorescence usually axillary, less frequently terminal, rarely ramiflorous, cauliflorous, or epiphyllous, usually paniculate with cymose branchlets (thyrsoid), less frequently racemose, fasciculate, or spicate, or flowers in pairs or solitary. Flowers bisexual or unisexual (plants monoecious, dioecious, or polygamous); 
rudiments of opposite sex usually well-developed in unisexual flowers. Calyx usually shallowly or deeply $(2)_{3}-5(7)$-lobed, less frequently truncate or with free sepals, rarely closed in bud and circumscissile at the base; aestivation open or imbricate. Petals 3-6(I4), free or less frequently united below, often partially fused to the staminal tube; aestivation imbricate or contorted, less frequently valvate. Filaments rarely completely free, usually partly or completely united to form a staminal tube, with or without appendages. Staminal tube $0.05-14 \mathrm{~cm}$ long, globose, urceolate, campanulate, cyathiform, or cylindrical and then sometimes curved or inflated distally, rarely ribbed; throat open or constricted; margin entire, crenate, lobed, or toothed, or bearing appendages; appendages very variable in shape, free or partly or completely united, as many as or twice as many as, rarely $3(-10)$ times as many as, the anthers. Anthers $(3) 5-10(23)$, hairy or glabrous, sometimes locellate, inserted apically on the filaments or on the margin of the staminal tube, or within the throat of the staminal tube and partially or completely included, usually alternate with the appendages, rarely opposite them; usually in a single whorl, rarely in two alternating whorls; connective sometimes produced to form a short or long appendage. Antherodes in 9 flowers smaller, not dehiscing or producing pollen. Disk intrastaminal, stipitate, patelliform, cyathiform, tubular, or absent, free from or partly or completely fused to the base of the staminal tube or ovary. Ovary (r)2-6(20)-locular; loculi uniovulate, biovulate, or multiovulate. Placentation axile or very rarely parietal. Ovules collateral, superposed, or biseriate. Style-head capitate or discoid, less frequently conical, pileate, or deeply lobed, or forming an ovoid, globose, fusiform, cylindrical, conical, or obconical receptaculum pollinis. Pistillode in of flowers narrower with a longer, more slender style, less glandular style head, and very small abortive ovules. Fruit a loculicidal or septifragal capsule, a berry, drupe, or very rarely a nut. Seed either winged and then usually attached to a large woody columella, or unwinged and then usually with a fleshy arillode or sarcotesta, rarely with a corky or woody sarcotesta, or exarillodiate and without a sarcotesta; seed sometimes endospermous, usually exendospermous. Embryo with plano-convex or flat, collateral, superposed, or rarely oblique cotyledons; radicle usually superior, less frequently abaxial, rarely adaxial; included, or extending to the surface, or long exserted.

Germination': Cotyledons emergent (phanerocotylar) or not (cryptocotylar), sometimes becoming green and photosynthetic. Hypocotyl elongating or not, sometimes swollen. Scale-leaves (cataphylls) sometimes produced before the first foliage leaves (eophylls). First foliage leaves opposite or spirally arranged, simple, pinnatisect, trifoliolate, or imparipinnate, the margin entire, toothed, or deeply lobed. Rhachis often winged.

Pollen: Pollen grains nearly always shed singly, very rarely in rhomboidal tetrads. Grains oblate-spheroidal, spheroidal, prolate-spheroidal, subprolate, or prolate, ro-80 (130) $\mu \mathrm{m}$, amb rounded or angular. Apocolpium small, medium, or large. Colpi sometimes shortly bifurcate. Ora circular, lalongate, or rarely lolongate, sometimes crassimarginate, very rarely zonorate. Exine usually smooth or minutely scabrous, less frequently verrucose, rugulose, or reticulate, usually thickened at the apertures.

Secondary Xylem: The secondary xylem is usually diffuse porous, rarely ring porous. Silica deposits are frequent in a small number of genera and occasional elsewhere. Vessels most frequently solitary and in radial groups of up to $10(-15)$, occasionally with tangential or oblique arrangement; pore clusters rare, $s-40(\mathrm{I}$ Io) per sq $\mathrm{mm}$, tangential diameter

1) In the following description of the mode of germination and morphology of the seedlings we are following the terminology in Duke (1965). 
(20) $60-\mathrm{I} 60(320) \mu \mathrm{m}$; intervascular pitting alternate, sometimes with coalescent apertures; pits $2.25-7.5 \mu \mathrm{m}$ diameter; vessel to ray pitting similar; vessel perforations exclusively simple; spiral thickening rarely present; tyloses absent; gum usually present. Ray tissue usually heterogeneous Kribs Type 3, or homogeneous Kribs Type I, or uniseriate-homogeneous or -heterogeneous, less frequently heterogeneous Kribs Type I or 2, or homogeneous Kribs Type 2; rays $\mathrm{I}-6(7)$-seriate, I5-50(100) cells high; the heterocellular with $\mathrm{I}(6)$ marginal rows; homocellular rays composed entirely of square or upright cells occasionally present. Crystals in marginal ray cells present or absent. Rays sometimes storied. Fibres septate or non-septate; fibre-pits predominantly on the radial walls, usually simple or with narrow borders, occasionally with conspicuous borders; walls thick to very thick; lumen open or plugged with gum. Parenchyma. Paratracheal: varying from sparcely scattered cells to vasicentric, aliform, confluent, and banded in various combinations; bands $\mathrm{I}-7$ (I I ) cells wide, (I) $3-7$ (I 3 ) per $\mathrm{mm}$, usually containing crystals in chambered cells. Apotracheal: terminal bands present or absent, with or without crystals in chambered cells. Diffuse parenchyma occasionally present, usually chambered and containing crystals.

A medium-sized family of woody plants in the tropics and subtropics of both hemispheres, comprising SI genera and probably no more than 550 species.

\section{FAMILY - MELIACEAE}

\section{SUBFAMILY I MELIOIDEAE}

Tribe I TURRAefae

Munronia, Naregamia, Turraea, Humbertioturraea, Calodecaryia, Nymania

Tribe 2 MELIEAE

Melia, Azadirachta

Tribe 3 vavaefae

Vavaea

Tribe 4 TRICHIIIEAE

Trichilia, Pseudobersama, Pterorhachis, Walsura, Lepidotrichilia, Malleastrum, Ekebergia, Astrotrichilia, Owenia, Cipadessa

Tribe 5 AgLaIEAe

Aglaia, Lansium, Aphanamixis, Reinwardtiodendron, Sphaerosacme

Tribe 6 GUARERAB

Heckeldora, Cabralea, Ruagea, Turraeanthus, Guarea, Chisocheton, Megaphyllaea, Synoum, Anthocarapa, Pseudocarapa, Dysoxylum

Tribe 7 SANDORICEAE

Sandoricum

SUBFAMILY II QUIVISIANTHOIDEAE

Quivisianthe

SUBFAMIIY III CAPURONIANTHOIDEAE

Capuronianthus

SUBFAMILY IV SWIETENIOIDEAE

Tribe I Cedreleat

Cedrela, Toona 
Tribe 2 SWIETENIEAE

Khaya, Neobeguea, Soymida, Entandrophragma, Chukrasia, Pseudocedrela, Schmardaea, Swietenia, Lovoa

Tribe 3 XYLOCARPEAE

Carapa, Xylocarpus

\section{SUBFAMILY I. MELIOIDEAE}

Buds naked. Leaves nearly always spirally arranged. Plants dioecious, or flowers hermaphrodite, or polygamous. Loculi uni- or bi-ovulate, or bi-ovulate with a third vestigial ovule, very rarely multi-ovulate; ovules collateral or superposed. Style-head variable. Fruit a fleshy or leathery loculicidal capsule, berry, drupe, or very rarely a nut. Seed never winged, never with a woody or corky testa, usually with a fleshy arillode or sarcotesta. Endosperm present or absent.

Secondary Xylem. Rays usually I or 2-seriate, rarely broader, homogeneous or heterogeneous. Crystals never present in marginal ray cells, usually present in wood parenchyma. Paratracheal parenchyma often abundant (confluent or banded).

\section{Tribe I. TURRAEEAE 1}

Leaves usually simple. Indumentum of simple or stellate hairs. Flowers hermaphrodite Staminal tube nearly always cylindrical, usually complete, or less frequently, filaments connate in the upper or lower half only. Anthers usually inserted on the margin of the staminal tube or apically on the filaments. Disk, when present, usually poorly developed, usually annular, patelliform and fused to the base of the staminal tube. Style-head often characteristically modified to form a receptaculum pollinis. Fruit nearly always a capsule. Seed usually with an adaxial fleshy arillode; endospermous.

Cotyledons flat, collateral; radicle superior, exserted.

P o 11 e n. Oblate to spheroidal; $3(s)$-colporate; exine usually verrucose or rugulose.

$\mathrm{S}$ e cond a r y $\mathrm{x}$ y l e m. Fibres non-septate.

I. Indumentum a mixture of simple and stellate or bifid hairs; petals fused to staminal tube below, rarely becoming free; disk, when present, tubular; sarcotesta adaxial, membraneous, swollen and hollow ............ I. Munronia

Ia. Indumentum of simple hairs; petals free from staminal tube; disk, when present, never tubular; seed usually with a fleshy arillode; sarcotesta, when present, never membraneous.

2. Filaments completely united or partly free at the apex for not more than one third of their length.

3. Fruit a capsule.

4. Leaves 3 -foliolate, leaflets shallowly lobed or entire, rhachis with a conspicuous wing to the base; staminal tube without appendages; stylehead sometimes modified to form a receptaculum pollinis; seed curved, truncate at base and apex, testa with irregular transverse ridges, puberulent; arillode fleshy, free except for attachment along raphe 2. Naregamia

1) We gratefully acknowledge the assistance of Prof. J. F. Leroy, Laboratoire de Phanérogamie, Muséum National d'Histoire Naturelle, Paris, who has provided us with much material and information on the new Malagasy genera in this and other tribes in the family. 
4a. Leaves simple (or in one species compound, but then leaflets deeply lobed to partite, rhachis unwinged at the base, and staminal tube with appendages); staminal tube appendages present or absent; style-head usually modified to form a receptaculum pollinis; seeds $0.2-0.8 \mathrm{~cm}$ long, not truncate at base and apex, nearly always smooth, glabrous; arillode fleshy, usually free except for a narrow attachment along adaxial surface below micropyle: cotyledons nearly always narrow; radicle long exserted ................. 3. Turraea 3a. Fruit indehiscent; leaves simple; staminal tube complete, with appendages; fruit large, seeds I.3-I.5 cm long; sarcotesta adaxial; hilum large; cotyledons broad; radicle very short, slightly exserted ...... 4. Humbertioturraea 2a. Filaments usually united only at the base, always free for more than half of their length.

5. Capsule not inflated, not deeply 4-lobed; anthers basifixed, not versatile; seed glabrous, smooth ........... 5. Calodecaryia

5a. Capsule inflated, deeply 4-lobed; anthers dorsifixed, versatile; seed puberulent, minutely verrucose ............ 6. Nymania

\section{MUNRONIA}

Munronia Wight, lllustr. I (1831) 147, t. 54; Icones Pl. Ind. I (1838) Explanation of plates s, t. 91; Harms in Engl. \& Prantl, Nat. Pflanzenfam., ed. 2, I9 bI (1940) 91, t. 21, fig. E, F, t. 22. - Fig. 2a, b. Philastrea Pierre, Bull. Soc. Linn. Paris I (188s) 47s.

Small shrubs or herbs with woody rootstocks. Leaves simple, trifoliolate or imparipinnate, often repand or remotely crenate or serrate. Indumentum a mixture of simple and bifid or stellate hairs. Flowers bisexual, solitary or in few-flowered axillary panicles. Calyx 5-lobed to near the base, lobes somewhat foliaceous. Petals 5, fused to the staminal tube below, rarely becoming free later. Staminal tube $1.5-5.5 \mathrm{~cm}$ long, narrowly cylindrical, the margin with Io narrow, entire or bilobed appendages, rarely with to reflexed filiform appendages arising some distance below the margin. Anthers 10, hairy, inserted on the rim of the staminal tube, alternating with the appendages; connective often produced apically to form a short or long or rarely filiform appendage. Disk tubular, free, or fused at the base to the staminal tube, or absent. Ovary 5-locular; loculi with 2 superposed ovules. Style slender; style-head capitate, sometimes with 5 minute stigmatic lobes. Fruit a s-valved loculicidal capsule; loculi I or 2-seeded. Seed plano-convex with a pergamentaceous testa and a large, membraneous, swollen sarcotesta covering the adaxial surface of the seed and surrounding the hilum. Embryo embedded in thin endosperm; cotyledons flat, collateral; radicle superior, short, exserted.

G e r m i n a t i o n: phanerocotylar; cophylls opposite, pinnatisect; metaphylls pinnate and spirally arranged (M. pumila (Moon) Wight).

Chromosome number: $2 n=50$ ( $M$. pinnata (Wall.) Harms).

Pollen: Pollen grains (3) 4 (s)-colporate, oblate-spheroidal or spheroidal $(70-85 \mu \mathrm{m}$, amb rounded). Apocolpium large. Ora circular or lalongate, sometimes crassimarginate. Exine scabrous or rugulose, thickened at the apertures.

Distribution: About to species from India eastwards to Malesia.

Type species: $M$. pumila (Moon) Wight (here chosen as lectotype).

Relationships: Munronia is a clearly defined genus, easily separable from all other genera of the Turraeeae. It differs from Turraea in the following characters: indumentum 

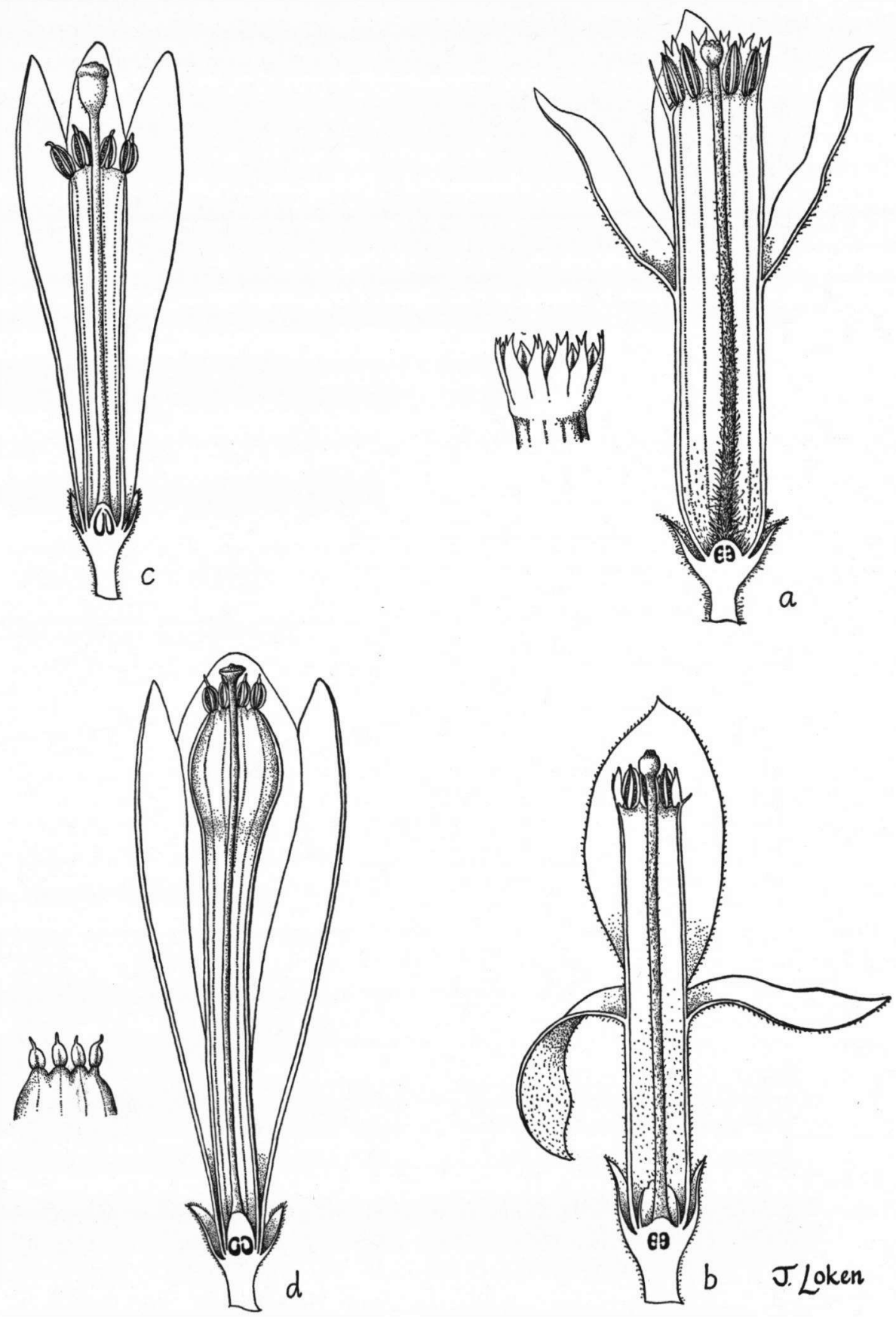

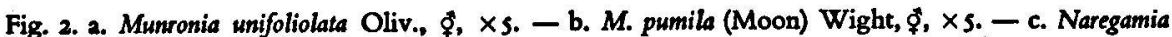
africana (C. DC.) Exell, ợ, $\times 2.5-$ d. N. alata Wight \& Arnott, \$̧, X2.5. (2. Henry 3963; b. Walker s.m; c. Gossweiler 10434; d. Johnson s.r.m.). 
a mixture of simple and bifid or stellate hairs (hairs simple in Turraea); petals fused to the staminal tube, rarely becoming free later (free in Turraea); in the shape and structure of the sarcotesta which is membraneous and covers the adaxial surface of the seed. The fleshy inner part disintegrates at maturity, leaving a hollow membraneous structure. Nymania is the only other genus in the Meliaceae with a similar adaxial sarcotesta, but in this case it is relatively poorly developed.

The characters mentioned above distinguish Munronia from all other genera of the Turraeeae and in addition, Munronia frequently has a free tubular disk and its pollen grains are nearly always 4-colporate; the former character is unknown and the latter very rare in Turraea. latter.

The relationship between Munronia and Naregamia is considered in detail under the

\section{NAREGAMIA}

Naregamia Wight \& Arn., Prod. Fl. Pen. Ind. Or. I (1834) Ir6, nom. cons.; Harms in Engl. \& Prantl, Nat. Pflanzenfam. ed. 2, 19 bI (1940) 90, t. 2I, figs. G, H. - Fig. 2 c, d.

Nelanaregam Adanson, Fam. Pl. 2 (1763) 343., nom. rejic.

Small shrubs or herbs with a woody rootstock. Leaves trifoliolate, leaflets shallowly lobed or entire, the rhachis broadly winged. Indumentum of simple hairs. Flowers bisexual, solitary or paired, axillary. Calyx 4 or 5 -lobed to the middle. Petals 4 or 5 , free, imbricate. Staminal tube $2-3.5 \mathrm{~cm}$ long, narrowly cylindrical, sometimes inflated at the apex, the margin entire or with small crenations bearing the anthers. Anthers 8 or Io, glabrous; connective produced apically to form an appendage shorter than or as long as the anther. Disk absent. Ovary 3-or 4-locular; loculi with 2 collateral ovules. Style slender; stylehead thinly discoid or modified to form an obconical to ovoid-cylindrical receptaculum pollinis.Fruit a 3- or 4-valved loculicidal capsule; loculi I- or 2-seeded. Seed curved, truncate at base and apex; testa thick and bony, with irregular transverse ridges, puberulent; arillode small, thin, fleshy, free except for attachment along the adaxial raphe. Embryo slightly curved, embedded in thick endosperm; cotyledons flat, collateral; radicle superior, long exserted, almost as long as the cotyledons.

Germination: phanerocotylar ( $N$. alata Wight \& Arn.)

Chromosome number: $2 \mathrm{n}=46$ ( $N$. alata Wight \& Am.)

Pollen: Pollen grains 3(4)-colporate, suboblate $(75-80 \mu \mathrm{m}$, amb rounded). Apocolpium large. Ora circular. Exine scabrous or verrucose, thickened at the apertures.

Distribution: Probably two species: one on the west coast of India, the other in Angola.

Type species: $N$. alata Wight \& Arn.

Relationships: Naregamia has obvious affinities with Munronia and Turraea, but is more closely related to the latter. It is, however, easily distinguished from Turraea by a number of characters.

Naregamia has trifoliolate leaves. Those of Turraea are simple, except for those of one recently discovered species (allied to Turraea pulchella (Harms) Pennington comb. nov. *) from Natal. This species has a mixture of trifoliolate and imparipinnate leaves, with deeply lobed or partite leaflets (shallowly lobed or entire in Naregamia), the rhachis unwinged at the base (broadly winged in Naregamia), a staminal tube with prominent

* Basionym : Nurmonia pulchella Harms, Ber. Deutsch. Bot. Ges. 35 (1917) 80, t. 1. 
appendages (appendages absent in Naregamia). In addition, the characteristic seed structure of Naregamia immediately separates it from Turraea. It is slender, curved, prominently truncate at the base and apex, and the thick bony testa has large, irregular, transverse ridges and is puberulent. The seed of all species of Turraea is rather swollen and rounded, not truncate at base and apex, usually with a smooth shining testa, and always glabrous.

Naregamia can be distinguished from Munronia by its simple hairs (simple and bifid or stellate in Munronia), free petals (fused to staminal tube in Munronia), glabrous anthers (hairy in Munronia), 3-or 4-locular ovary with collateral ovules (5-locular with superposed ovules in Munronia), and the characteristic shape and structure of its seed and arillode. The tubular disk, frequently present in Munronia, is not known in Naregamia.

\section{TURRAEA}

Turraea L., Mant. Pl. 2 (177I) I 50, 237; Harms in Engl. \& Prantl, Nat. Pflanzenfam., ed. 2, I9 bI (1940) 85. t. 20. - Fig. 3 a-e.

Quivisia Cav., Dissert. 7 (1789) 367; Comm. ex. Jussieu, Gen. Pl. (1789) 264.

Gilibertia J. F. Gmel., Syst. Nat. 2 (I791) 682, non Ruiz \& Pav. (1794).

Calodryum Desv., Ann. Sc. Nat. 9 (1826) 40I, t. 5 I.

Ginnania M. J. Roem., Synops. Hesp. Monogr. I (1846) 79, 9r, nom. illeg., non Scop. (1777), nec F. G. Dietr. (I804).

Scyphostigma M. J. Roem., tom. cit. 80, 94 .

Rutaea M. J. Roem., tom. cit. 80, 93.

Payeria Baill., Adansonia I (I860) 50, t. 3.

Grevellina Baill, Bull. Soc. Linn. Paris 2 (1894) 1160.

Nurmonia Harms, Ber. Deutsch. Bot. Ges. 35 (1917) 80, t.l.

Small trees or shrubs. Leaves simple, entire or less frequently with a repand, sinuate, or crenate margin, or very rarely (I species) leaves compound. Indumentum of simple hairs. Flowers bisexual, solitary, or fasciculate, or in short axillary or terminal cymes or panicles, rarely paired, very rarely ramiflorous. Calyx (3) 4 or $5(6)$-lobed or -toothed to above or below the middle, rarely almost entire, or with foliaceous lobes. Petals $(3)_{4}$ or 5 , free, imbricate or contorted, rarely valvate at the apex. Staminal tube $0.1-\mathrm{I} 4 \mathrm{~cm}$ long, complete or filaments free at the apex for one third or less of their length; tube cylindrical or rarely cyathiform, sometimes curved or inflated distally; terminated by simple or bilobed, free or partly or completely fused, often reflexed appendages, as many as or twice as many as the anthers, or margin shallowly lobed or entire. Anthers (7)8- $\mathrm{IO}(20)$, glabrous or less frequently hairy, inserted on the margin of the staminal tube or inside below the margin, opposite to or alternating with the appendages, or apically on the filaments; apiculate or connective produced apically or basally to form a long or short appendage. Disk small, annular, patelliform, cyathiform, or absent; when annular then sometimes free, when patelliform or cyathiform then always fused to the base of the ovary or staminal tube, sometimes ribbed and with the margin lobed. Ovary $(3)_{4}-\mathrm{IO}(20)-$ locular; loculi with 2 collateral, oblique or superposed ovules. Style usually expanded apically to form an ovoid, globose, fusiform, cylindrical, conical, or obconical style-head (receptaculum pollinis), surmounted by a discoid or rounded stigmatic area; less frequently only slightly or not expanded and then capitate or narrowly discoid and often with 4 or 5 small stigmatic lobes. Fruit a (3)4-1o(20)-valved, leathery or woody, usually rather thin-walled, loculicidal capsule; loculi I or 2 -seeded. Seed $0.2-0.8 \mathrm{~cm}$ long, planoconvex, slightly pointed at the apex; testa hard, shining, nearly always smooth, glabrous; arillode present, fleshy, usually free except along the narrow adaxial line of attachment to just below the micropyle, rarely partially fused to the seed. Embryo embedded in 


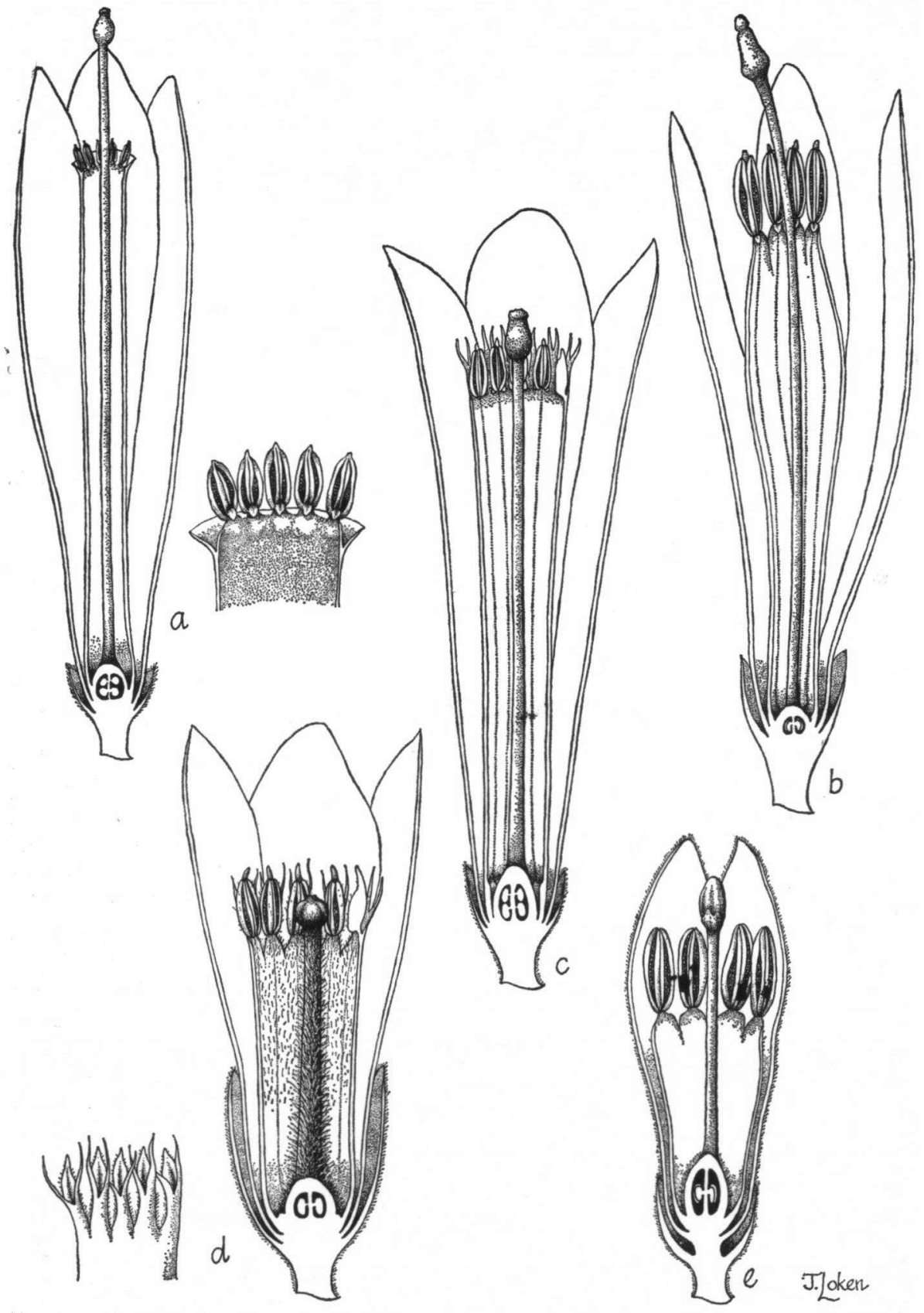

Fig. 3. 2. Turraea cabrae De Wildem. \& Th. Dur., ఫै, ×2.5. - b. T. pubescens Benth.,

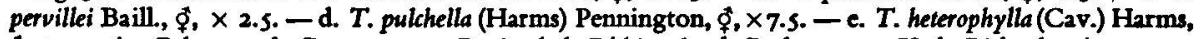
\$̆, X7.5. (a. Cabra s.n.; b. Brown s.n.; c. Perrier de la Báthie 965; d. Pegler 730; e. Herb. Richard s.n.). 
thick endosperm, straight or curved; cotyledons flat, rather narrow, collateral; radicle superior, long exserted.

Germination: phanerocotylar; eophylls spirally arranged, simple, margin sinuate to coarsely toothed (T. nilotica Kotschy \& Peyr., T. obtusifolia Hochst.).

Chromosome numbers: $2 n=50$ ( 7 species), $2 n=36$ ( $T$. $s p$. nov.).

Pollen: Pollen grains $3(4)$-colporate, oblate, suboblate, or oblate-spheroidal, very rarely spheroidal; (30-IO5 $\mu \mathrm{m}$; amb rounded or triangular). Apocolpium medium or large. Ora circular or lalongate, rarely lolongate, sometimes crassimarginate. Exine scabrous, verrucose, rugulose, or reticulate, very rarely smooth, sometimes rhickened at the apertures.

Secondary xylem: Vessels solitary and in radial groups of $2-5(15)$, sometimes with pore clusters, sometimes showing oblique or tangential patterns; tangential diameter (I5) $20-140 \mu \mathrm{m}$; intervascular pits $3-6 \mu \mathrm{m}$; gum usually absent. Ray tissue heterogeneous Kribs Type 3, homogeneous Kribs Type 1 , or uniseriate-homogeneous or -heterogeneous; rays I or $2(3)$-seriare, up to 40 cells high, the heterocellular rays with I(2) marginal rows. Fibres non-septate. Parenchyma. Paratracheal: vasicentric, aliform, confluent and banded in various combinations, rarely absent; crystals usually absent. Apotracheal: terminal bands present or absent. Diffuse cells present or absent.

Distribution: About 24 species in tropical Africa, perhaps 35 in Madagascar, Mauritius, and the Comores, and about 6 in tropical Asia and Australia.

Type species: $T$. virens $L$.

Relationships: Turraea as defined here includes four genera formerly recognized by other authors, viz. Quivisia, Calodryum, Grevellina, and Nurmonia. Harms, in his latest treatment of the Meliaceae (1940), placed all these, except Nurmonia, in synonymy with Turraea.

Typical Turraea as illustrated by the majority of African and Asiatic species, is characterized by a long, cylindrical, complete staminal tube, usually with terminal appendages, and a style-head strongly modified to form a receptaculum pollinis. The four synonymous genera mentioned above were based on the following characters:

Size of flower and shape of staminal tube (small flowers and staminal tube sometimes cyathiform in Quivisia).

Degree of fusion of the filaments (filaments free at the apex in Calodryum and Nurmonia).

Presence or absence of staminal tube appendages (no appendages in Grevellina, Calodryum, Quivisia).

Presence or absence of the receptaculum pollinis (absent in Nurmonia and Quivisia).

Leaf-shape (Grevellina has very slender leaves).

Although the extremes are different there are many intermediate conditions. The size of flower and shape of staminal tube ranges from the minute flower of Quivisia oppositifolia Cav. with its cyathiform staminal tube less than $0.5 \mathrm{~cm}$ long, through species with a shortly cylindrical staminal tube (e.g. $T$. robusta Gürke) to the other extreme of $T$. macrantha Danguy whose staminal tube is $12 \mathrm{~cm}$ long. There is no sharp discontinuity between the partly free filaments of some Quivisia or Calodryum and the complete staminal tube of typical Turraea. Among the Malagasy species there is much variation in the form of the style-head, from the pronounced receptaculum pollinis to the simple capitate stylehead of Quivisia. Grevellina is similar in all respects to typical Turraea, except for the lack of staminal tube appendages and leaf shape which is not a generic character. Apart from the characters mentioned above, Nurmonia is also unusual in having foliaceous calyx lobes, but this condition is approached in some Malagasy Turraea (e.g. Calodryum tubiflorum Desv. $=T$. lanceolata Cav.). 
The presence or absence of staminal tube appendages is the only character showing a clear discontinuity, but as this feature is not correlated sufficiently highly with any other, it cannot be used to divide Turraea in any natural way.

Turraea is a very variable genus with extreme species widely different, but linked by many intermediates. The variable characters are not correlated or are insufficiently correlated to give discontinuities between groups of species. A similar pattern of variation occurs in other large genera of the Meliaceae, e.g. Trichilia. In Turraea, as in Trichilia, there are a small number of unifying features common to all or nearly all species. These are the simple leaves (all species except one) and the structure of the fruit, seed, and embryo. The fruit is always a loculicidal capsule, generally with rather thin-walled valves. The seeds are small in proportion to the size of the fruit, have a hard, shining, glabrous testa with a fleshy adaxial arillode. The seeds of all species have copious endosperm and a straight or curved embryo with thin, rather narrow, collateral cotyledons and a long exserted radicle. It is the fruit, seed, and arillode characters which distinguish Turraea from its satellite genera Humbertioturraea, Calodecaryia, and Nymania. The relationships of these will be discussed in detail under the respective genera.

Note: Turraea breviflora Ridley. The relationships of this endemic Malayan species are uncertain. It differs from all known Turraea species in several important characters: stellate indumentum, valvate corolla, shortly tubular disk, uniovulate loculi. It also lacks the modified style-head present in most species of Turraea. The sparse field data available indicates that the species is dioecious (all known Turraea species are hermaphrodite). The 3 or 4 colporate suboblate pollen grains are similar to those of Turraea and Munronia.

The vegetative and floral structure suggests that this species has almost equal affinities with both Turraea and Munronia, but it is nevertheless quite distinct from both. Until the fruit is collected it is not possible to place it with any greater accuracy.

\section{HUMBERTIOTURRAEA}

Humbertioturraea J. F. Leroy, Compt. Rend. Acad. Sci. Paris 269 (1969) 2322. — Fig. 4a.

Small trees or shrubs. Leaves simple, entire. Indumentum of simple hairs. Flowers bisexual, solitary, paired, or in small axillary fascicles. Calyx 4- or 5-lobed to halfway. Petals 4 or $\mathrm{s}$, free, imbricate. Staminal tube $3-8 \mathrm{~cm}$ long, \pm complete, cylindrical or sometimes slightly expanded at the apex, terminated by emarginate to deeply bifid, sometimes partly fused, often reflexed appendages alternating with the anthers. Anthers 10-12, sparsely hairy or glabrous, inserted on the very short free portion of the filaments; connective produced apically or basally to form a short, sparsely hairy or glabrous appendage. Disk small, patelliform or cyathiform, partly or completely fused to the base of the staminal tube, often ribbed and the margin lobed. Ovary s-1 s-locular; loculi with 2 superposed ovules. Style expanded apically to form a globose, conical, or discoid receptaculum pollinis surmounted by a rounded or discoid, papillose stigmatic area. Fruit indehiscent with a thick leathery-fleshy pericarp, 5-IO-locular, loculi usually with 2 superposed seeds. Seed $1.3-1.5 \mathrm{~cm}$ long, plano-convex, with a thick, woody, smooth, glabrous testa; sarcotesta adaxial, hilum large. Embryo embedded in thick endosperm, almost straight; cotyledons flat, broad, collateral; radicle superior, very short, slightly exserted.

Pollen: Pollen grains 3-colporate, suboblate ( $85-90 \mu \mathrm{m}$; amb rounded or triangular). Apocolpium medium. Ora circular or lalongate. Exine scabrous.

Distribution: 3 or 4 species in Madagascar. 
Type species: $H$. seyrigii J. F. Leroy.

Relationships: In its floral features Humbertioturraea is similar in all respects to typical Turraea, but it differs in its completely indehiscent fruit. It is difficult to decide from dried material whether the fruit is a berry or drupe, but it appears to be leathery-fleshy in texture, and from field observation it is known to rot on the ground where it falls. Humbertioturraea is the only genus in the tribe with an indehiscent fruit.

It also differs from Turraea in some minor characters. The size of the seed relative to that of the fruit is far greater in Humbertioturraea than in the few species of Turraea which have an equally large fruit. The adaxial sarcotesta which leaves a large scar is unknown in Turraea which has an arillode. Here the arillode is usually free except for a narrow line along the adaxial side and leaves a narrow scar, except in a few species (Quivisia), where it may be broadened slightly. The embryo also differs from that of Turraea. It has broad flat cotyledons and a very shortly exserted radicle; the cotyledons of Turraea are slender, often parallel-sided, and the radicle is much longer in proportion to the size of the cotyledons.

\section{CALODECARYIA}

Calodecaryia J. F. Leroy, Compt. Rend. Acad. Sci. Paris 250 (1960) 4026; Journ. Agric. Trop. Bot. Appl. 7 (I960) 379. - Fig. 4b.

Small trees or shrubs. Leaves simple, entire. Indumentum of simple hairs. Flowers bisexual, in small axillary panicles or fascicles. Calyx 4- or 5 -lobed to the middle. Petals 4 or 5 , free, contorted. Filaments 0.6 - I.I cm long, connate in the lower half only, often free almost to the base, without appendages. Anthers 8-10, glabrous, basifixed. Disk annular or patelliform, often indistinct, fused to the base of the staminal tube. Ovary 4-or 5-locular; loculi with 2 collateral ovules. Style usually slightly expanded below the capitate to discoid style-head, usually with 4 or 5 minute stigmatic lobes. Fruit a 2-5valved, leathery, loculicidal capsule; loculi i or 2-seeded. Seed plano-convex to reniform, rounded at both ends; testa thick, hard, smooth, projecting inwards deeply on the adaxial side, glabrous; small fleshy sarcotesta on the adaxial surface and surrounding the minute hilum. Embryo strongly curved, surrounded by thick endosperm; cotyledons flat, slender, collateral; radicle superior, rather long, exserted.

Germination: phanerocotylar; eophylls spirally arranged, simple; axillary buds sometimes develop from the cotyledons (C. crassifolia J. F. Leroy)

Chromosome number: $2 n=36$ (C. crassifolia J. F. Leroy)

Pollen: Pollen grains 3-colporate, oblate ( $58-65 \mu \mathrm{m}$; amb triangular). Apocolpium large. Ora lalongate. Exine scabrous or smooth.

Secondary xylem: Vessels: solitary and in radial groups of up to I 5 ; tangential diameter $15-32 \mu \mathrm{m}$; intervascular pits $2-3 \mu \mathrm{m}$; gum absent. Ray tissue: uniseriate-homogeneous; rays up to is cells high. Fibres: non septate. Parenchyma: Paratracheal: absent. Apotracheal: thin terminal bands numerous. Crystals absent.

Distribution: One or two species in Madagascar.

Type species: $C$. pauciflora J. F. Leroy.

Relationships: Calodecaryia is closely related to Turraea, particularly to those species formerly included under Calodryum. It differs from Turraea in the degree of fusion of the filaments and in the characteristics of the seed and sarcotesta. In Turraea the filaments are completely or almost completely fused whereas in Calodecaryia they are never fused to more than halfway. 
The seed differs from that of Turraea in its much greater degree of curvature, so that the micropyle, hilum, and chalaza approach one another very closely. There is also a peculiar inward projection of the testa on the adaxial side which is unknown in Turraea. The hilum is surrounded by a small fleshy sarcotesta which has not been observed in any species of Turraea. The embryo is very strongly curved, resembling that of Nymania. The relationship of Calodecaryia with Nymania is discussed under the latter.

\section{NYMANIA}

Nymania S. O. Lindb., in nota sub Aitonia J. \& G. Forst., Notis. Sällsk. Fl. Fenn. Förhandl. 9 (1868) 290; Harms in Engl. \& Prantl, Nat. Pflanzenfam. ed. 2, 19 bI (1940) 94, t. 24; non Nymania K. Schum. (1905) (Euphorbiaceae) (nom. illegit.). - Fig. 4c.

Aitonia Thunb., Phys. Sällsk. Handl. Stockh. (Act. Lund.) I (1781) I66, nom. illegit; non Aytonia J. \& G. Forst., Charact. Gen. Fl. (I776) I47 (Marchantiaceae).

Aytonia L. f. Suppl. Pl. (I78I) 49, 303 (emend. Aitonia, 468) nom. illegit..

Carruthia O. Kuntze, Rev. Gen. I (189I) I4I.

Shrub with simple leaves spirally arranged and fasciculate on short lateral shoots. Indumentum of simple hairs. Flowers bisexual, solitary, axillary. Calyx 4-lobed to near the base. Petals 4, free, imbricate. Filaments $1.6-2.3 \mathrm{~cm}$ long, distinctly curved, fused near the base. Anthers 8 or 9 , glabrous, fixed dorsally towards the base, versatile. Disk thin, patelliform, partly fused to the base of the staminal tube. Ovary 4(5)-locular; loculi with 2 collateral ovules. Style long, slender, with a simple, minute, capitate style-head. Fruit an inflated, deeply 4(5)-lobed, thinly membraneous, loculicidal capsule; loculi I(2)seeded. Seed reniform, with a thick, rather woody, minutely verrucose, puberulent testa, the adaxial depression filled with a fleshy sarcotesta which surrounds the hilum. Embryo strongly curved, embedded in thin endosperm; cotyledons flat, slender, collateral; radicle superior, rather short, exserted.

Germination: phanerocotylar; eophylls opposite, simple, growth of apical shoot soon stops and axillary buds develop from first and second pairs of eophylls. Eophylls on axillary shoots spirally arranged and opposite.

Chromosome number: $2 n=40$.

Pollen: Pollen grains 3-colporate, suboblate $(65-70 \mu \mathrm{m}$; amb triangular). Apocolpium large. Ora lolongate, usually crassimarginate. Exine scabrous or rugulose.

Secondary xylem: Vessels: in radial groups of $2-8$ and with some pore clusters; tangential diameter $20-40 \mu \mathrm{m}$; intervascular pits c. $6 \mu \mathrm{m}$; gum absent. Ray tissue: homogeneous Kribs Type I; rays I or 2-seriate, up to 20 cells high. Fibres: non-septate. Parenchyma. Paratracheal: very sparse, vasicentric, consisting mainly of scattered cells; crystals absent.

Distribution: One species in South Africa.

Type species: $N$. capensis (Thunb.) Lindb.

Relationships: This genus, which was originally placed by Thunberg (178I) in the Monadelphia ' 8 -andria', and by the younger Linnaeus (1781) in Octandria Monogyna, was recognized as belonging to the Meliaceae by both De Jussieu (1789) and Ventenat (1799). Some subsequent authors have not agreed with this conclusion and it has been placed in no fewer than six families: Malvaceae (Cavanilles, I788), Hesperideae (Batsch, 1802), Rutaceae (D. Don, 1832), Z Ygophyllaceae (Harvey, 1838), Aitonieae (Harvey, 1860), Sapindaceae tribe Dodonaeae (Hook $f$. in Bentham \& Hooker, 1862), in Sapindaceae tribe Aitonieae (Baillon, 1874/s), and Aitoniaceae (Airy Shaw, 1966).

Radlkofer ( 1890 ) discusses the affinities of this genus at some length and shows con- 

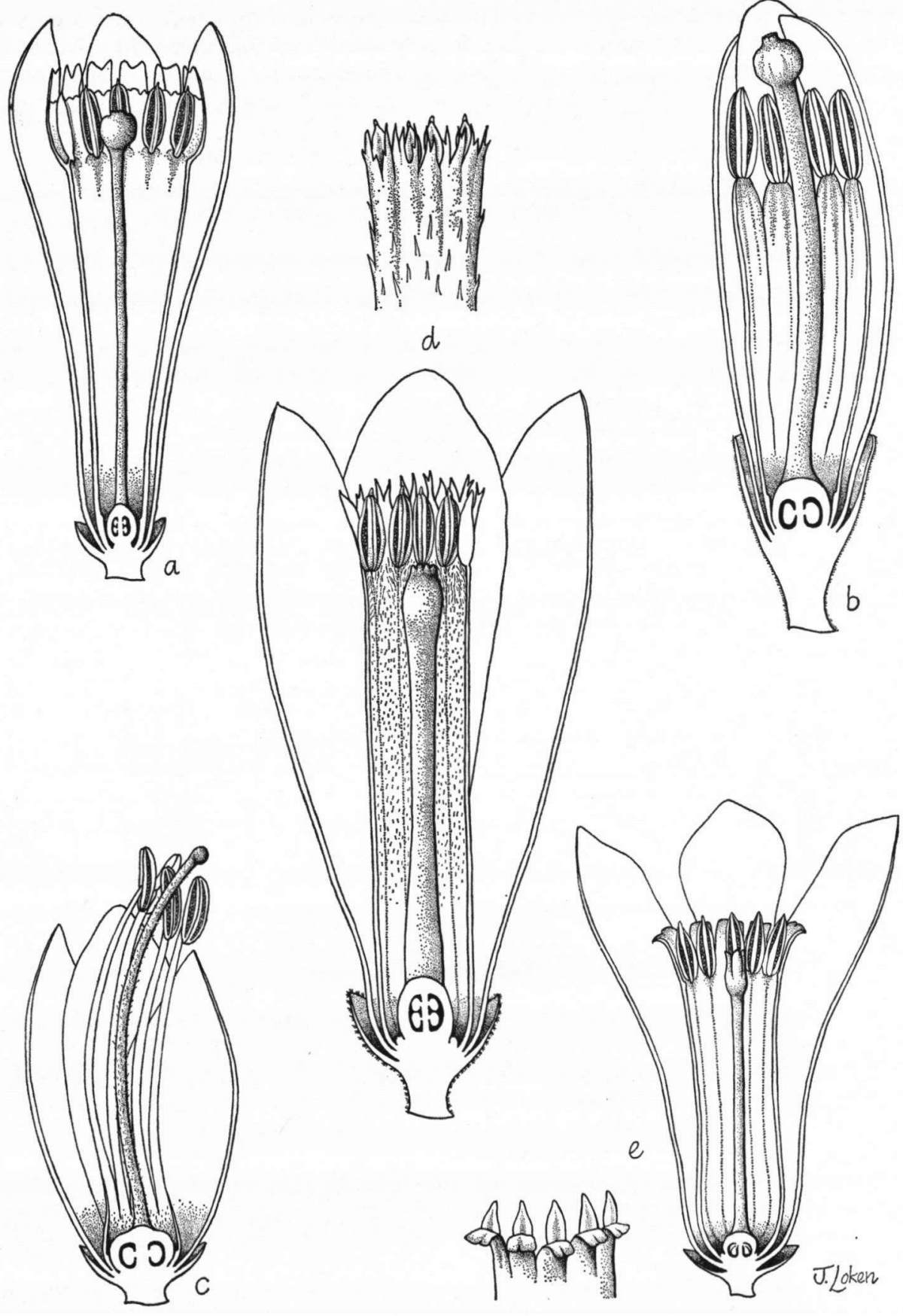

Fig. 4. 2. Humbertioturaea sp., $\$, \times 2.5 .-$ b. Calodecaryia crassifolia J. F. Leroy, $\$, \times 7.5 .-c$. Nymania

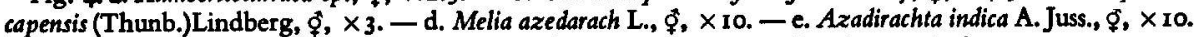
(2. R. F. 7225; b. S. F. 8194; c. von Breda 4132; d. Pennington 8099; e. Pennington 7833). 
vincingly that the relationship with the Meliaceae is very close. Although there is a superficial resemblance between the fruit of Nymania and that of Melianthus (Melianthaceae, a satellite genus of the Sapindaceae) or Dodonaea (Sapindaceae), many other characters, notably the 4-merous flowers, antisepalous position of the carpels, endospermous seed, curved embryo, and intra-staminal disk would not exclude it from the Meliaceae. Radlkofer also supports his conclusion with anatomical characters; in particular he notes that the continuous ring of sclerenchymatous tissue, which is present in the bark of the twigs of the Sapindaceae is absent from Nymania, as it is from all other Meliaceae.

In general appearance, largely because of the linear sclerophyllous leaves in fascicles on the stems and the large inflated capsule, Nymania differs markedly in appearance from other Meliaceae, except Calodecaryia and a few Malagasy species of Turraea which have similar foliage.

The inflated capsule is not known elsewhere in the Meliaceae and Nymania lacks some of the distinctive features of the family e.g. the complete staminal tube and expanded style-head. The pollen grains, which are 3-colporate with meridionally elongate pores, suboblate and with a scabrous or rugulose exine, look different from typical Meliaceae, but are similar to those of Humbertioturraea and some species of Turraea. In its morphology Nymania differs from Turraea in having staminal filaments fused only at the base, in the dorsifixed versatile anthers (basifixed and not versatile in Turraea), and in its seed structure. The seed of Nymania is strongly curved, with a minutely verrucose, puberulent testa; that of Turraea is straight or less curved, with a usually smooth, glabrous testa. The inner layer of the testa is strongly concave on the adaxial side, and the concavity filled by a fleshy sarcotesta which distintegrates when the seed is mature leaving a cavity, a condition unknown in Turraea, but approached in Calodecaryia. The latter genus provides a connecting link between Nymania and Turraea. It differs from Nymania in its basifixed nonversatile anthers, in its larger style-head, and in its capsule which is not inflated. The seed of Calodecaryia is strongly curved like that of Nymania, but with a smooth glabrous testa (verrucose and puberulent in Nymania). The testa projects inwards deeply on the adaxial side, but is not strongly concave as in Nymania.

The secondary xylem of Nymania confirms its position in the Meliaceae: it is very similar to that of Calodecaryia and some species of Turraea (Calodryum). The very small vessels and sparse or absent paratracheal parenchyma give a characteristic combination of characters not found elsewhere in the family.

\section{Tribe 2. MELIEAE}

Leaves pinnate or bipinnate. Petioles with paired sunken glands at the base. Indumentum of simple or stellate hairs. Flowers hermaphrodite or male. Staminal tube cylindrical, complete, with appendages. Disk annular. Style-head 3-8-lobed. Fruit a drupe. Seed exarillodiate, with thin endosperm. Cotyledons collateral; radicle superior, exserted.

Pollen. Prolate-spheroidal or subprolate, less frequently oblate-spheroidal; 3 or 4colporate; exine smooth or minutely scabrous.

Secondary xylem. Minute vessels present with spiral thickening; fibres non-septate; apotracheal terminal parenchyma present.

I. Leaves 2-3-pinnate; innovations with stellate indumentum; ovary 4-8-locular; loculi with 2 superposed ovules; style-head 4-8-lobed; drupe 3-8-seeded, with a thick bony endocarp . . . . . . . . . . . . . . 7. Melia Ia. Leaves pinnate; indumentum simple; ovary 3 -locular; loculi with 2 collateral ovules; style-head 3-lobed; drupe 1(2)-seeded; endocarp thin . . . . . . 8. Azadirachta 


\section{MELIA}

Melia L. [Gen. P1. ed. I. (1737) I27] Sp. PL. I (1753) 384; Harms in Engl. \& Prantl, Nat. Pflanzenfam. ed. 2, I9 bl (I940) 99, t. 26, figs. A-L, t. 27. - Fig. 4d.

Azedarach Mill., Gard. Dict. Abr. ed. 4 (1754).

Zederachia Heist. ex Fabr., Enum. Meth. Pl. (1759) 221.

Antelaea Gaertn., Fruct. Sem. Pl. I (1788) 277, t. 58.

Monopodial trees or treelets. Indumentum a mixture of simple and tufted-stellate hairs. Leaves 2-3-pinnate. Inflorescence a many-flowered axillary panicle, the ultimate branchlets often cymose. Flowers bisexual and male on the same individual (polygamous). Calyx 5(6)-lobed to near the base, sepals sometimes imbricate at the base. Petals $5(6)$, free, imbricate. Staminal tube $0.4-\mathrm{I} \mathrm{cm}$ long, narrowly cylindrical, slightly expanded at the mouth, ro-r2-ribbed, terminated by slender, filiform, truncate, or 2-4-lobed appendages, as many as or up to twice as many as the anthers. Anthers Io(I2), hairy or glabrous, apiculate or acute; inserted on the margin of the staminal tube or just inside, alternate with or opposite to the appendages. Disk small, annular or patelliform, free, surrounding the base of the ovary. Ovary 4-8-locular; loculi with 2 superposed ovules. Style-head capitate to coroniform, with 4-8 short erect or incurved stigmatic lobes. Fruit a 3-8-locular drupe; endocarp thick, bony, hollowed out at base and apex; loculi I(2)-seeded. Seed oblong, laterally compressed, exarillodiate; testa leathery, sometimes slightly swollen and fleshy round the hilum. Embryo embedded in thin endosperm; cotyledons flat, collateral; radicle superior, short, projecting from the cotyledons.

Germination: phanerocotylar; eophylls opposite, pinnatisect or trifoliolate $(M$. azedarach L.).

Chromosome numbers: $n=14,2 n=28$ ( 5 species).

Pollen: Pollen grains (3) 4-colporate, prolate-spheroidal, subprolate, or oblate-spheroi$\mathrm{dal}$ ( $50-60 \mu \mathrm{m}$; amb rounded). Apocolpium medium. Ora circular. Exine smooth or minutely scabrous, thickened at the apertures.

Secondary xylem: ring porous. Vessels: in clusters; minute vessels with spiral thickening are also present, often in more or less tangential rows; tangential diameter 40$240 \mu \mathrm{m}$; intervascular pits $6 \mu \mathrm{m}$; gum present. Ray tissue: homogeneous Kribs Type 2; rays 5-7-seriate, up to 40 cells high, a few heterocellular with I marginal row. Fibres: non-septate. Parenchyma. Paratracheal: vasicentric and confluent. Apotracheal: terminal bands present with crystals. Diffuse crystalliferous cells abundant.

Distribution: $c$. $s$ confused species in the Old World tropics. Introduced elsewhere. Type species: $M$. azedarach L.

Relationships: Melia and Azadirachta are closely related both morphologically and anatomically. The morphological differences are enumerated in the key.

Jacobs (I96I) mentions a useful field character for separating sterile specimens of these two genera. Both have glands at the base of the petiole. In Melia there is a pair of orbicular glands, while in Azadirachta there is in addition a pair of linear glands below these. This is a good field character, but the glands are often difficult to observe in herbarium material.

Both genera share a number of interesting anatomical characters not recorded elsewhere in the Meliaceae, in particular the clusters of minute vessels with spiral thickening of the walls. Melia differs anatomically from Azadirachta in having ring porous secondary xylem. 


\section{AZADIRACHTA}

Azadirachta A. Juss., Mém. Mus. Hist. Nat. Par. 19 (?1830) 220, t. 2, n. 5; Harms in Engl \& Prantl, Nat. Pflanzenfam. ed. 2, 19 bI (1940) 102, t. 26, figs. M-S. - Fig. 4e.

Antelaea auct., non Gaertn.: Adelb., Blumea 6 (1948) 315.

Trees with pinnate leaves. Indumentum of simple hairs. Panicles axillary, many-flowered. Flowers bisexual and male on the same individual (polygamous). Calyx s-lobed to the lower half, the lobes imbricate. Petals 5 , free, imbricate. Staminal tube $0.3-0.5 \mathrm{~cm}$ long, cylindrical, slightly expanded at the mouth, terminated by ro rounded, truncate, emarginate, or bilobed appendages, often partially united to form a frill. Anthers ro, glabrous, tapering to a short point, inserted at the base of, and opposite to, the appendages. Disk annular, fused to the base of the ovary. Ovary 3-locular; loculi with 2 collateral ovules. Style-head expanded to form a ring bearing 3 acute, partially fused, papillose stigmatic lobes. Fruit a I(2)-seeded drupe with a thin cartilaginous endocarp. Seed ovoid, pointed above, with a thin membraneous testa; exarillate, with a small adaxial sarcotesta. Embryo surrounded by very thin endosperm; cotyledons plano-convex, collateral; radicle superior, short, projecting from the cotyledons.

Germination: phanerocotylar; cophylls opposite, trifoliolate, leaflets deeply incised, pinnatifid, or partite.

Ch r o m o s o m e $\mathrm{n} \mathrm{u} \mathrm{m} \mathrm{ber} \mathrm{s:} 2 \mathrm{n}=28,30 ; \mathrm{n}=\mathrm{I}_{4}$ ( $A$. indica A. Juss.).

P oll e n: Pollen grains 3- or 4-colporate, prolate-spheroidal or subprolate ( $55-65 \mu \mathrm{m}$; amb rounded). Apocolpium medium. Ora circular. Exine smooth, slightly thickened at the apertures.

S e c o n d a r y x y l e m: Vessels: solitary and in radial pairs, with pore clusters; minute vessels with spiral thickening also present; tangential diameter $40-240 \mu \mathrm{m}$; intervascular pits 4.5-7.5 $\mu \mathrm{m}$; gum present. Ray tissue: heterogeneous Kribs Type 3, or homogeneous Kribs Type 2; rays 2-7 seriate, up to 20 cells high, the heterocellular with I marginal row. Fibres: non-septate. Parenchyma: Paratracheal: vasicentric. Apotracheal: terminal bands present with crystals. Diffuse crystalliferous cells present or absent. Silica deposits present or absent.

$\mathrm{D}$ is $\mathrm{t} \mathrm{r}$ i b u $\mathrm{t}$ i o $\mathrm{n}$ : Two species in the Indo-Malesian region.

T y pe s pe ci e s: $A$. indica A. Juss.

$\mathrm{Re}$ lat i o $\mathrm{sh}$ i p s: The affinites of this genus with Melia are discussed in detail under the latter.

\section{Tribe 3. VAvakeAB}

Trees or treelets with sympodial('Terminalia') branching. Leaves simple. Indumentum of simple hairs. Flowers mostly bisexual. Staminal tube cylindrical or cyathiform; filaments partly free; appendages absent. Disk poorly developed or absent. Loculi uniovulate, biovulate, or multiovulate. Fruit a berry. Seed with a thin sarcotesta; sometimes with thin endosperm. Cotyledons plano-convex, collateral.

P oll e n: Prolate, subprolate, or prolate-spheroidal; 3(4)-colporate; ora lalongate to zonorate.

S e c on dary x y le m: Vessels solitary or paired; rays very heterogeneous (Kribs Type I, 2, or 3); fibres nearly always septate.

\section{VAVAEA}

Vavaea Benth. in Hook., Lond. Journ. Bot. 2 (1843) 212; Harms in Engl. \& Prantl, Nat. Pflanzenfam. ed. 2, I9 bI (1940) 97, t. 21, fig. J, K, t. 25; Pennington, Blumea 17 (1969) 351. — Fig. 5a, b.

Lamiofrutex Lauterbach, Nova Guinea 14 (1924) 147. 
Trees or treelets with sympodial ('Terminalia') branching. Leaves simple, clustered at the ends of branchlets. Inflorescence usually axillary, rarely extra-axillary, a panicle or less frequently a cyme. Plants sometimes polygamous. Calyx shallowly or deeply 4 or $5(7)-$ lobed, with open or rarely imbricate aestivation. Petals $(3)_{4}-6$, free, imbricate or rarely contorted. Filaments $0.2-6.7 \mathrm{~cm}$ long, fused in the lower half or beyond, the staminal tube cyathiform, shortly tubular or long tubular and then sometimes slightly curved; appendages absent, rarely represented by a pair of short rounded lobes. Anthers 9-23, hairy or glabrous, attached at the ends of the filaments. Disk patelliform or cyathiform, fused to the base of the staminal tube, or forming androecial ribs, or absent. Ovary 2-6locular, loculi uniovulate or with $2(3)$ collateral ovules or with 4-Io ovules in 2 rows. Style-head capitate or discoid. Fruit a berry with a thin and fleshy or thick and rather woody pericarp,c ontaining I-3(7) seeds. Seed ovoid or plano-convex; seed coat cartilaginous, surrounded by a thin sarcotesta. Embryo sometimes surrounded by a thin layer of residual endosperm; cotyledons plano-convex, rather thick, collateral; radicle superior, small, included or extending to the surface.

Germin a t i on: cryptocotylar; eophylls opposite, simple ( $V$. amicorum Benth.).

P olle n: Pollen grains 3(4)-colporate, prolate-spheroidal, subprolate, or prolate (longest axis $45-130 \mu \mathrm{m}$; amb rounded to triangular). Apocolpium medium to large. Ora lalongate to zonorate. Exine usually scabrous, less frequently smooth, thickened at the apertures.

$\mathrm{S}$ e c o n d a r y $x$ y l e m: Vessels : solitary and in radial pairs, rarely with pore clusters,
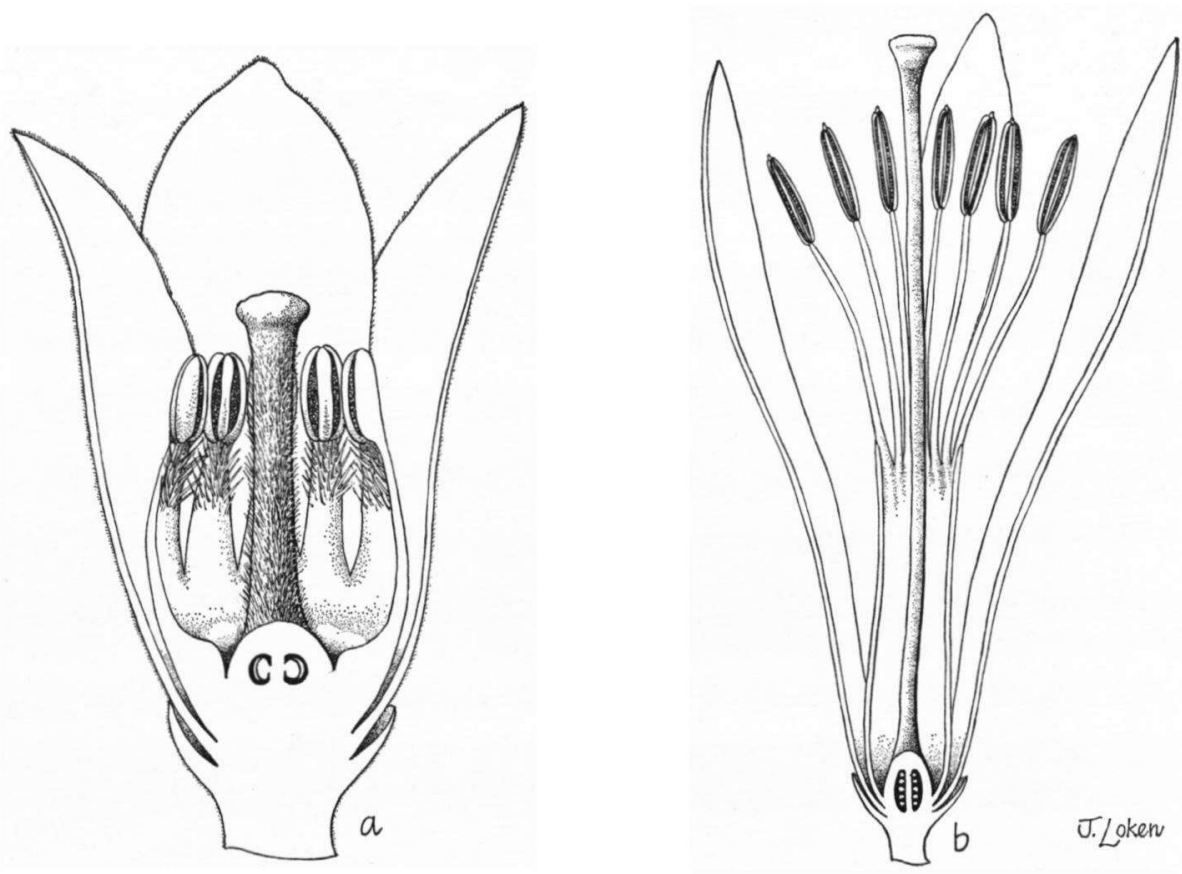

Fig. 5. 2. Vavaea amicorum. Benth., ఫุ, XI5. - b. V. papuana F. M. Bail,, q, XI.5. (a. Pennington 8122; b. Brass 25848 ). 
rarely showing local oblique patterning; tangential diameter $40-160 \mu \mathrm{m}$; intervascular pits 3.75-6 $\mu \mathrm{m}$; gum absent. Ray tissue: heterogeneous Kribs Type 1, 2, or 3; rays I- or 2-seriate, up to 40 cells high, the heterocellular with $\mathrm{I}-3$ marginal rows. Fibres: septate or partially septate, very rarely non-septate. Parenchyma: Paratracheal; vasicentric, aliform, confluent, with crystals. Apotracheal: terminal bands rarely present. Diffuse crystalliferous parenchyma frequent.

D is t ributio n: 4 species from Sumatra eastwards through Malesia to northern Australia, Melanesia, and Polynesia.

Ty pe species: $V$. amicorum Benth.

Relationships: Vavaea occupies an isolated position within the Melioideae (Pennington, l.c.). It possesses most of the individual morphological, anatomical, and palynological characters of the subfamily but in a distinctive combination enabling it to be easily distinguished from all other genera. Its relationships are with the Turraeeae and Trichilieae, especially the latter. It has the simple leaves of the Turraeeae, but has the baccate fruit, seed with sarcotesta, and embryo structure of some Trichilieae. The poorly developed disk is present in both these tribes.

The wood anatomy of Vavaea is very distinct and unlike that of the Turraeeae or Trichilieae. It resembles that of Sandoricum (Sandoriceae), sharing with this genus the predominantly solitary vessels and very heterogeneous ray tissue. It differs, however, in having narrower rays and septate fibres.

The 3-colporate pollen grains differ from those of the majority of genera in the Meliaceae which are 4-colporate. Only Vavaea, Aglaia, Sandoricum, and certain species of a few other genera have 3-colporate, prolate to prolate-spheroidal grains. The pollen grains of $V$. papuana F. M. Bail. and $V$. tubiflora Pennington differ from all others in the Meliaceae in being zonorate.

\section{Tribe 4. TRICHIIIEAB}

Leaves usually pinnate, rarely trifoliolate or unifoliolate. Indumentum of simple or stellate hairs. Either flowers hermaphrodite or plants dioecious. Staminal tube usually complete, or filaments connate in the upper or lower half or rarely free. Anthers nearly always inserted apically on the margin of the staminal tube or on the filaments. Disk poorly developed, usually annular or patelliform. Fruit a capsule, berry, or drupe. Seed usually arillodiate or with a sarcotesta; usually without endosperm. Cotyledons usually plano-convex and collateral, with superior radicle.

P o 11 e n: Usually prolate-spheroidal or prolate; $3-5$-colporate; exine nearly always smooth or scabrous.

Se c ondary xylem: Fibres nearly always non-septate; apotracheal terminal parenchyma usually present; paratracheal parenchyma usually vasicentric, aliform and confluent.

I. Fruit a capsule.

2. Filament appendages $(3)_{4}-6$ (го) times as many as the anthers in male flowers, $2-3(4)$ times as many in the female; leaf-rhachis winged; indumentum stellate; filaments free in upper half; anthers hairy; disk thick, fleshy, annular

12. Pterorhachis

2a. Filament appendages absent or not more than twice as many as the anthers:

3. Capsule (4) 5 -valved; valves thick, woody, rugulose, bearing branched antler-like appendages; petals free, imbricate; filaments partly free, without appendages; seed small, with thin endosperm. . . . . I I. Pseudobersama 
3a. Capsule 2 or 3(4)-valved without antler-like appendages; petals free or united at the base, imbricate or valvate; staminal tube complete, or filaments partly or completely free, with or without appendages; seed usually without endosperm. . .............. Io. Trichilia

Ia. Fruit a berry (see also Ib. below).

4. Style-head well-developed, capitate, truncate, or pileate; petiolules usually pulvinate; petals usually imbricate; filaments partly or completely free; ovary 2-4-locular, loculi uniovulate or with 2 collateral ovules; seed usually arillodiate

I3. Walsura

4a. Style-head minute, capitate; petiolules not pulvinate; petals valvate; staminal tube complete, or filaments partly free; ovary often unilocular, rarely 2- or 3locular, loculi with 2 superposed ovules; seed exarillodiate and without a sarcotesta ................. Is. Malleastrum

Ib. Fruit a drupe.

5. Indumentum stellate.

6. Corolla valvate; loculi uniovulate; style-head capitate; endocarp thin, membraneous or cartilaginous . . . . . . . . . I4. Lepidotrichilia

6a. Corolla imbricate; loculi bi -ovulate; style-head thick, discoid; endocarp very thick and woody . . . ........ I7. Astrotrichilia

5a. Indumentum simple.

7. Corolla with imbricate aestivation.

8. Staminal tube with lobes or appendages; sepals free, imbricate; loculi uniovulate; style-head discoid, bearing a large, conical, 2 or 3 -lobed stigma; endocarp very thick and woody; seed with thin sarcotesta

18. Owenia

8a. Staminal tube without appendages; calyx shallowly lobed; loculi with 2 superposed ovules; style-head capitate or thick discoid, without a conical stigma; endocarp thin; seed exarillodiate, without a sarcotesta 16. Ekebergia

7a. Corolla with valvate aestivation; filaments united only near the base, with appendages; endocarp bony; seed exarillodiate, without a sarcotesta

19. Cipadessa

\section{I0. TRICHILIA}

Trichilia P. Browne, Hist. Jamaica (1756) 278; Harms in Engl. \& Prantl. Nat. Pflanzenfam. ed. 2, I9 bI (1940) 104, t. 28, figs. H-S; t. 31 E, F; J. J. F. E. De Wilde, Revision of the species of Trichilia on the African Continent, (1968) 207 pp. - Fig. 6a-f.

Barbilus P. Browne, Hist. Jamaica (1756) 216.

Barola Adans., Fam. Pl. 2 (1763) 344, 524, nom. illeg.

Elcaja Forsk., Fl. Aegypt.-Arab. (1775) 127.

Portesia Cav., Diss. 7 (1789) 369, t. 215, 216.

Heynea Roxb. ex Sims in Curt., Bot. Mag. 41 (I8Is) t. 1738; Harms in Engl. \& Prantl, Nat. Pflanzenfam. ed. 2, 19 bI (1940) I17, t. 3I, figs E, F.

Odontandra Willd. ex M. J. Roem. \& Schultes, Syst. Veg. 5 (I819) SI1.

Moschoxylum A. Juss., Mém Mus. Hist. Nat. Par. I9 (?1830) 237.

Trichilia sect. Torpesia Endl., Gen. Pl. (1840) rosI.

[Geniostephanus Fenzl, Flora 27 (1844) 312, nom. nud.]

[Heynichia Kunth, Index Sem. Hort. Berol. (1844) 8; Linnaea I8 (1844) 504, nom. nud.]

Odontosiphon M. J. Roem., Synops. Monog. Hesperid. I (1846) 85, 106.

Torpesia (Endl.) M. J. Roem., tom. cit. 86, 116.

Rochetia Delile in Rochet, Sec. Voy. Adels et Choa (1846) 344.

Mafureira Bertol., Mem. Accad. Sci. Bologna 2 (I850) 269. 
Acrilia Griseb., Fl. Brit. West Ind. Isl. (1864) 129.

Pholacilia Griseb., loc. cit.

Symphytosiphon Harms, Bot. Jahrb. 23 (1896) 165.

Trichilia sect. Acanthotrichilia Urb., Symb. Antill. I (1899) 328.

Acanthotrichilia (Urb.) Cook \& Collins, Contrib. U.S. Nat. Herb. 8 (1903) 65, 258.

Ailantopsis Gagnep.. Not. Syst. II (1944) I63.

Picroderma Thorel ex Gagnep., tom. cit. 165.

Trees, treelets, or rarely suffrutices. Indumentum usually of simple, rarely of stellate hairs. Leaves pinnate, rarely trifoliolate or unifoliolate. Flowers unisexual (plants dioecious), in axillary or rarely terminal panicles, rarely fasciculate or cymose. Calyx shallowly or deeply 4 or $5(7)$-lobed, rarely entire or of free imbricate sepals. Petals 4 or $5(7)$, free or united below, imbricate or valvate. Filaments $0.1-2 \mathrm{~cm}$ long, completely united to form a cyathiform, urceolate, globose, or cylindrical staminal tube, the margin entire, toothed, lobed, or with simple or bilobed appendages; or filaments partly (rarely completely) free, and then with or without 2 terminal appendages. Anthers S-Io(13), hairy or glabrous, inserted between the teeth or appendages on the margin of the staminal tube, or apically on the filaments; antherodes narrower than the anthers, not dehiscing, without pollen. Disk a fleshy annulus surrounding the base of the ovary, or broadly stipitate, or patelliform, or cyathiform, free from, or partly or completely fused to, the base of the staminal tube or ovary, or forming androecial ribs, or absent; often less distinct in the female flower. Ovary 2-4(6)-locular, loculi with I or 2 collateral or less frequently superposed ovules; pistillode smaller but often with well-developed abortive ovules. Stylehead capitate or rarely annular, surmounted by a conical or deeply 2-6-lobed stigmatic area. Fruit an ellipsoid, ovoid, or globose 2 or $3(4)$-valved loculicidal capsule; valves leathery or woody, loculi I or 2-seeded. Seed plano-convex, partly or completely surrounded by a thin or fleshy arillode, or occasionally with a partial or complete sarcotesta; exendospermous or occasionally with thick endosperm. Embryo with plano-convex or less frequently flat, collateral cotyledons; radicle superior, included or occasionally exserted; rarely with oblique or superposed cotyledons and abaxial radicle.

$\mathrm{G}$ e r $\mathrm{m}$ in a $\mathrm{t}$ i o $\mathrm{n}$ : cryptocotylar or phanerocotylar; eophylls opposite, soon becoming spirally arranged, simple, entire; cataphylls present in $T$. connaroides (Wight \& Arn.) Bentv., followed by spirally arranged, simple eophylls.

Chrom os o m e numbers: $n=14,2 n=24,28,46,50,92$, c. 360 .

P o ll e n: Pollen grains 3 or 4(5)-colporate, prolate-spheroidal, subprolate, or prolate, rarely spheroidal or oblate-spheroidal (30- $55 \mu \mathrm{m}$; amb rounded or rarely quadrangular). A pocolpium large or medium. Ora circular or lalongate. Exine smooth or rarely scabrous or verrucose, thickened at the apertures.

$\mathrm{S}$ e c o n d a r y $x$ y l e m: Vessels: solitary and in radial groups of $2-4(8)$, very rarely with pore clusters; tangential diameter $(20) 40-220 \mu \mathrm{m}$; intervascular pits $2.25-4.5(6)$ $\mu \mathrm{m}$; gum present or absent. Ray tissue: heterogeneous Kribs Type 3, uniseriate homogeneous or heterogeneous, rarely homogeneous Kribs Type I; rays I or $2(s)$-seriate, up to 3s(so) cells high, the heterocellular with I marginal row. Fibres: non-septate. Parenchyma: Paratracheal: vasicentric, aliform, and confluent, sometimes with bands, in various combinations. Apotracheal: terminal bands usually present, with crystals. Diffuse cells often present, usually crystalliferous. Silica deposits present or absent.

$\mathrm{D}$ is $\mathrm{t} \mathbf{r}$ i b u $\mathrm{t}$ i o $\mathrm{n}$ : Tropical America (c. so species) and Africa (c. $\mathrm{I}_{4}$ species) with two species in the Indo-Malayan region.

Ty pe species: $T$. hirta $L$.

$\mathrm{R}$ el a t i o $\mathrm{s}$ h i p s: Harms divided Trichilia into ten sections, some of which were 
based on imperfect material and do not show the generic characters. Thus section Pterotrichilia contained one species which has been justifiably transferred to Ekebergia; section Pterotorhachis is now accommodated within the recently described Malagasy genus Malleastrum; section Lepidotrichilia has been elevated to generic rank by Leroy; the section Astrotrichilia is also treated as a genus by Leroy who includes in it section Peltotrichilia. In all these cases the fruit is indehiscent. When they are removed, Trichilia is a much more natural entity, still variable, but the fruit is always a capsule and the seed always has an arillode or sarcotesta. The remaining five sections of Harms are unsatisfactory. They are based on the degree of fusion of the staminal filaments, the structure of the disk, and the presence or absence of stellate hairs, all characters which are variable within the genus but uncorrelated. The degree of fusion of the filaments can vary within wide limits in a single species (e.g. between male and female flowers of $T$. havanensis Jacq.) and there is no clear-cut distinction between the condition with partially fused filaments and that with completely fused filaments.

In the first edition of Die Natïrlichen Pflanzenfamilien ( 1896 ) Harms, following Kurz, combined Heynea with Walsura, but kept it separate in the second edition (1940). More recently (1962) Bentvelzen has combined it with Trichilia, an opinion we would provisionally accept. Since, however, both Heynea and Walsura have a haploid chromosome number of $\mathrm{I}_{4}$ (Rao, 1969, and Mehra et al, 1969), which is so far unknown in Trichilia, we believe the matter is worthy of further study.

\section{PSEUDOBERSAMA}

Pseudobersama Verdcourt, Journ. Linn. Soc., Bot. Lond. 55 (1956) 504, t. I, - Fig. 6g.

Trees with pinnate leaves. Indumentum of simple hairs. Flowers unisexual (plant dioecious), in axillary thyrses. Calyx s(6)-lobed to the middle. Petals 5 , free, imbricate. Filaments c. $0.35 \mathrm{~cm}$ long, connate at the base for one-third to two-thirds of their length; without appendages. Anthers II or 12, hairy, inserted at the end of the filaments; antherodes not dehiscing, without pollen. Disk patelliform, partly fused to the base of the ovary. Ovary (4)s-locular; loculi with 2 collateral ovules; pistillode much narrower, 3-locular, sometimes with vestigial ovules. Style-head scarcely broader than the style, capitate, obscurely 4-or 5-lobed. Fruit a (4) S-valved loculicidal capsule; the very thick, woody, valves prominently rugulose, the ridges in places developed into branched antlerlike appendages; loculi 2-seeded. Seed small, ovoid to globose, partly surrounded by a fleshy arillode. Embryo surrounded by thin endosperm; with collateral, plano-convex cotyledons; radicle superior, slightly exserted or extending to the surface.

Germin a ti on: cryptocotylar; eophylls opposite, simple, entire; subsequent eophylls become spirally arranged, with a deeply and irregularly toothed margin:

Chromosome n u m e r: $2 n=46$.

P oll e n: Pollen grains 4-colporate, subprolate (45-50 $\mu \mathrm{m}$; amb rounded). Apocolpium medium. Ora circular. Exine smooth or scabrous, thickened at the apertures.

$S$ e c o n d a r y $x$ y l e m: Vessels: solitary and in radial rows of $2-5$, with occasional pore clusters; tangential diameter $20-40 \mu \mathrm{m}$; intervascular pits $3 \mu \mathrm{m}$; gum present. Ray tissue: uniseriate-homogeneous or -heterogeneous; rays up to 30 cells high, the heterocellular with I marginal row. Fibres: non-septate. Parenchyma: Paratracheal: aliform and confluent. Apotracheal: terminal bands present, with crystals.

$D$ i s $r$ i b u t i o n: One species on the East coast of Africa, from Kenya to Natal.

T y p e s p e c i s: $P$. mossambicensis (Sim) Verdcourt. 

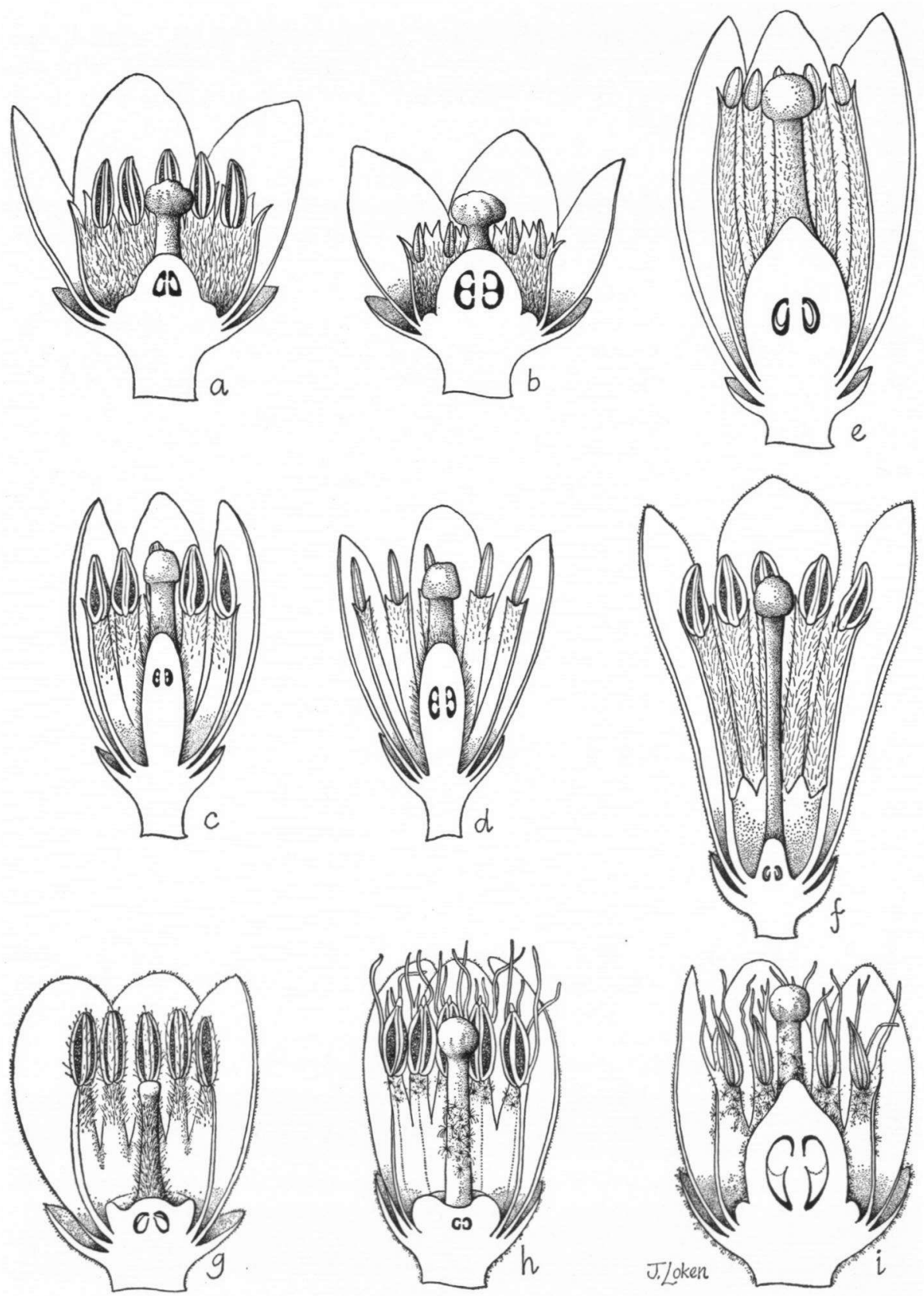

Fig. 6. a. Trichilia havanensis Jacq., $\delta, \times 7$; b. ditto, $9, \times 7 .-$ c. T. hirta L., §, $\times 7$; d. ditto, $9, \times 7 .-$ c. T. martineaui Aubrév. \& Pellegrin, ㅇ, $\times 5$; f. ditto, $\delta, \times 4 .-$ g. Pseudobersama mossambicensis (Sim) Verdcourt, 6 , $\times 7$. - h. Pterorhachis zenkeri Harms, $7, \times 7 ;-$ i. ditto, $9, \times 7$. (a. Pennington $\mathcal{E}$ Sarukhán 9546; b. Pennington $\&$ Sarukhán 9571; c. Scott Gentry 1647; d. Pringle 6394; e. de Wilde 3620-A; f. King 299; g, h. Cult. Wageningen s.n.; i. de Wilde s.n.). 
Relation sh i ps: This monotypic genus differs from Trichilia in possessing a very woody 5 -valved capsule bearing conspicuous ridges which are in places developed into short antler-like appendages. The fruit contains seeds which are rather small in relation to the size of the capsule.

The secondary xylem of Pseudobersama can be readily distinguished from that of African species of Trichilia by the very large number ( $80-110$ per sq $\mathrm{mm}$ ) of small (20-40 $\mu \mathrm{m}$ diameter) vessels arranged in radial rows of $2-5$ and the rather sparse aliform and confluent parenchyma. African species of Trichilia have up to 30 vessels per sq $\mathrm{mm}$ with a tangential diameter ranging from $40-220 \mu \mathrm{m}$. However, several American species of Trichilia, e.g. T. surumuensis C. DC., T. trifolia L., have sparse parenchyma, combined with more numerous vessels per sq $\mathrm{mm}(50-70)$ than the African species, but fewer than Pseudobersama.

In our opinion Pseudobersama can be maintained as a genus distinct from Trichilia, but only just. The type species, based on fruiting material, was first described as a Bersama (Melianthaceae). Verdcourt, who recognized it as Meliaceae, placed it in a new genus. Of the characters which serve to distinguish Pseudobersama from the African species of Trichilia, some occur sporadically in American species. Had Verdcourt studied the whole of Trichilia before creating the genus, he might equally have justifiably placed it in Trichilia.

\section{I2. PTERORHACHIS}

Pterorhachis Harms, Bot. Jahrb. 22 (1895) I5s; in Engl. \& Prantl, Nat. Pflanzenfam., ed. 2, 19 bI (1940) 94, t. 23. - Fig. 6h, i.

Treelet with stellate indumentum. Leaves imparipinnate or trifoliolate; rhachis winged. Inflorescence axillary, thyrsoid. Flowers unisexual (plant dioecious). Calyx 5 -lobed to near the base, with open or slightly imbricate aestivation. Petals 5 , free, imbricate. Staminal tube $0.35-0.45 \mathrm{~cm}$ long, urceolate or shortly cylindrical, filaments free in the upper half and terminated by (3) $4-6$ (ro) unequal filiform appendages, the outer pair longer than the others and I.5-3 times as long as the anthers. Anthers (9)ro, with a few hairs on the back, inserted just below the terminal appendages; connective produced to form a point or short slender appendage. Filament appendages in female flowers 2 or $3(4)$; antherodes very slender, not dehiscing, without pollen. Disk a swollen annulus fused to the base of the ovary. Ovary 3-locular; loculi with I or 2 superposed ovules; style-head capitate with $3(4)$ minute obtuse lobes. Pistillode very slender, scarcely expanded at the base, 3(4)-locular, loculi with I or 2 vestigial ovules. Fruit a $3(4)$-valved loculicidal capsule; loculi I(2)-seeded. Seed plano-convex with a flattened base; testa leathery. Arillode thinfleshy, surrounding the basal $\frac{1}{3}$ to $\frac{1}{2}$ of seed. Endosperm absent. Embryo with plano-convex, collateral cotyledons; radicle superior, included or extending to the surface.

C h r o m os om e n u m b r: $\mathrm{n}=14$ ( $P$. zenkeri Harms).

P o 11 e n: Pollen grains 3 or $4(5)$-colporate, oblate-spheroidal or spheroidal (c. $60 \mu \mathrm{m}$; amb rounded). Apocolpium large. Ora circular. Exine smooth.

$S$ e c o n d a r y $x$ y l e m: solitary and in radial rows of $2-6$, with a few pore clusters; tangential diameter $20-60 \mu \mathrm{m}$; intervascular pits $3 \mu \mathrm{m}$; gum present. Ray tissue: heterogeneous Kribs Type 3, but some rays are homocellular; rays I- or 2-seriate, up to 25 cells high, the heterocellular with I marginal row. Fibres: non-septate. Parenchyma: Paratracheal: vasicentric. Apotracheal: terminal bands present.

$\mathrm{D}$ i s $\mathrm{tr}$ i b u t $\mathrm{i}$ o n: One or possibly two species in Cameroun and Gabon.

Ty p e s e ci es: $P$. zenkeri Harms. 
Relationships: Harms, who had not examined mature fruit, unaccountably placed Pterorhachis in the Turraeeae next to Cipadessa. The only important morphological feature Pterorhachis shares with true members of this tribe is the winged rhachis (shared by Naregamia which is, however, different in all other respects). In gross morphological features Pterorhachis is very similar to Trichilia from which it differs principally in having more numerous filament appendages. The appendages are more numerous in the male Howers than in the female, but in the latter a high proportion of the filaments of every flower bears 3 appendages. This immediately distinguishes Pterorhachis from Trichilia whose filaments never have more than two appendages.

The secondary xylem of Turraea, Pterorhachis, and Trichilia is so similar that it is of no assistance in determining their relationships. However, the pollen of Pterorhachis is quite different from that of the Turraeeae, and in all essential features confirms its close relationship with Trichilia. Pterorhachis does, however, differ from most species of Trichilia in its spheroidal grains, but this feature occurs occasionally in Trichilia, as in T. hirta L.

\section{WALSURA}

Walsura Roxb. [Hort. Beng. (1814) 32, nom. nud.], Fl. Ind. ed. 2, 2 (1832) 387; Harms in Engl. \& Prant, Nat. Pflanzenfam., ed. 2, 19 bI (1940) I18, t. 31, figs. A-D. - Fig. 7a, b.

[Monocyclis Wall. ex Voigt, Hort. Suburb. Calc. (1845) 135, nom. nud.]

Surwala M. J. Roem., Synops. Hesp. Monogr. I (1846) 85, 108.

[Scytalia Ham. ex Wall., Cat. (1847) 8048 E, nom. nud., non Gaertn. (1788).]

[Melospermum Scortech. ex King, Journ. As. Soc. Bengal 64 (2) (1895) 83, nom. nud.]

Napeodendron Ridley, Journ. Roy. As. Soc. Straits Branch 82 (1920) 179.

Trees or treelets. Indumentum of simple hairs. Leaves imparipinnate, trifoliolate, or unifoliolate; lower epidermis usually papillose; petiolules usually pulvinate. Inflorescence either axillary, or subtended by a small caducous scale-leaf and then crowded and apparently terminal, or borne on short axillary or lateral shoots; panicles usually large, rarely much reduced and subfasciculate; ultimate ramifications often cymose. Flowers bisexual and male or unisexual (then plants dioecious). Calyx deeply (4) $5(6)$-lobed or of free sepals, aestivation imbricate or open. Petals $(4)_{5}(6)$, free, usually imbricate, less frequently valvate, rarely contorted. Stamens $0.1-0.4 \mathrm{~cm}$ long, filaments usually fused in the lower half or to half or three quarters of their length, less frequently free; often terminated by a pair of lanceolate or deltate appendages or teeth. Anthers (7)10(14), hairy or glabrous, inserted apically on the filaments between the appendages (when present); connective often produced to form a short acute appendage; antherodes smaller, not dehiscing, without pollen. Disk in male and hermaphrodite flowers annular or patelliform; in female flowers represented by a small swelling at the base of the enlarged ovary. Ovary 2(3)-locular, loculi with 2 collateral ovules, or incompletely 4 -locular and then the loculi uniovulate, ovoid and swollen in female and hermaphrodite flowers; style very short or absent; stylehead capitate, or stout and truncate, or pileate, often with 2 or 3 short apiculi. Pistillode with a small flattened ovary immersed in the disk containing vestigial ovules, style present, style-head broader than in the female and hermaphrodite flowers. Fruit 2 I or 2-seeded berry with a fleshy or fibrous-fleshy pericarp. Seed partially or completely surrounded by a fleshy arillode, or exarillodiate. Endosperm absent. Embryo with plano-convex, collateral cotyledons; radicle superior, included or extending to the surface.

G e r m in a t i o n: cryptocotylar; cataphylls minute, followed by spirally arranged, simple, entire eophylls.

Chrom os om e numbers: $n=14,2 n=28$.

Pollen: Pollen grains 4(s)-colporate, prolate-spheroidal, subprolate or prolate 
(35-85 $\mu \mathrm{m}$; amb rounded or quadrangular). Apocolpium small to medium. Ora circular or lalongate. Exine smooth or scabrous, thickened at the apertures.

$\mathrm{S}$ e c o nd a r y x y l e m: Vessels: solitary or in radial groups of $2(3)$; tangential diameter $60-120 \mu \mathrm{m}$; intervascular pits $3 \mu \mathrm{m}$; gum present or absent. Ray tissue: heterogeneous Kribs Type 3, or homogeneous Kribs Type I or 2, or uniseriate heterogeneous; rays I-4-seriate, up to 40 cells high, the heterocellular with I(2) marginal rows. Fibres: non-septate. Parenchyma: Paratracheal: vasicentric, aliform, confluent, and sometimes banded; crystals present or absent. Apotracheal: terminal bands present or absent. Diffuse cells present or absent. In some cases the parenchyma cells in radial section are partially storied and very short (only $\mathrm{I}-3$ times as tall as broad).

$\mathrm{D}$ i s $\mathrm{t} \mathbf{r}$ i b u $\mathrm{t}$ i o $\mathrm{n}$ : About seven species in the Indo-Malesian region.

T y pe s peci es: $W$. piscidia Roxb. (equals $W$. trifolia (A. Juss.) Harms).

Relations h i s: The relationships of Walsura with Trichilia, Malleastrum, and Cipadessa are discussed under these genera.

\section{LEPIDOTRICHIIIA}

Lepidotrichilia (Harms) J. F. Leroy, Comp. Rend. Acad. Sci. Paris, 247 (1958) ro25; Journ. Agr. Trop. Bot Appl. 5 (1958) 673. - Fig. 7c.

Trichilia sect. Lepidotrichilia Harms in Engl. \& Prantl, Nat. Pflanzenfam. ed. 1, 3 (4) (1896) 306; ed. 2, IgbI (1940) I12, t. 28, figs. T-V.

Trees with imparipinnate leaves. Indumentum stellate. Flowers bisexual or sometimes unisexual, in axillary thyrses. Calyx shallowly s(6)-lobed. Petals 5, free, valvate. Filaments $0.3-0.7 \mathrm{~cm}$ long, connate in the lower half or to above half way, terminated by a pair of narrowly lanceolate to deltate-acuminate appendages, or completely fused to form a shortly cylindrical staminal tube with a toothed margin. Anthers 10, hairy or glabrous, inserted between the teeth or appendages. Antherodes similar, rather slender, not dehiscing, without pollen. Disk absent. Ovary 2-5-locular; loculi uniovulate. Style-head capitate, surmounted by 3-5 obscure or erect stigmatic lobes. Fruit a I-5-seeded drupe with a thin membraneous or cartilaginous endocarp. Seed oblong to globose, exarillodiate; testa thin and membraneous or slightly fleshy. Endosperm absent. Embryo with plano-convex, collateral or oblique cotyledons; radicle superior or abaxial, included or slightly projecting.

Germination: cryptocotylar; eophylls opposite, simple, entire, becoming trifoliolate.

Chromosome n u m b e r: $2 \mathrm{n}=38$ (L. volkensii (Harms) Leroy).

P oll e n: Pollen grains 4-colporate, prolate-spheroidal (33-45 $\mu \mathrm{m}$; amb rounded or quadrangular). Apocolpium medium. Colpi often shortly bifurcate; short colpi transversales sometimes present. Ora circular or lalongate. Exine medium or thick, smooth thickened at the apertures.

$S$ e c on d a r y x y l e m: Vessels: solitary and in radial rows of $2-5$; tangential diameter $40-140 \mu \mathrm{m}$; intervascular pits $3-4.5 \mu \mathrm{m}$; gum present or absent. Ray tissue: a mixture of uniseriate-homogeneous and -heterogeneous; rays rarely partly biseriate, up to 20 cells high, the heterocellular with I marginal row. Fibres: non-septate. Parenchyma: Paratracheal: vasicentric, often of scattered cells, sometimes aliform. Apotracheal: bands present, with crystals.

$\mathrm{D}$ is $\mathrm{t} \mathrm{r}$ ib u $\mathrm{t} \mathrm{i}$ o $\mathrm{n}$ : One species in east Africa and three in Madagascar.

T y pe s p e ci es: L. convallariaeodora (Baill.) J. F. Leroy.

$\mathrm{R}$ el a t i o n sh i ps: Lepidotrichilia may be distinguished from all species of Trichilia by its fleshy indehiscent fruit. Valvate aestivation of free petals is known from only one 

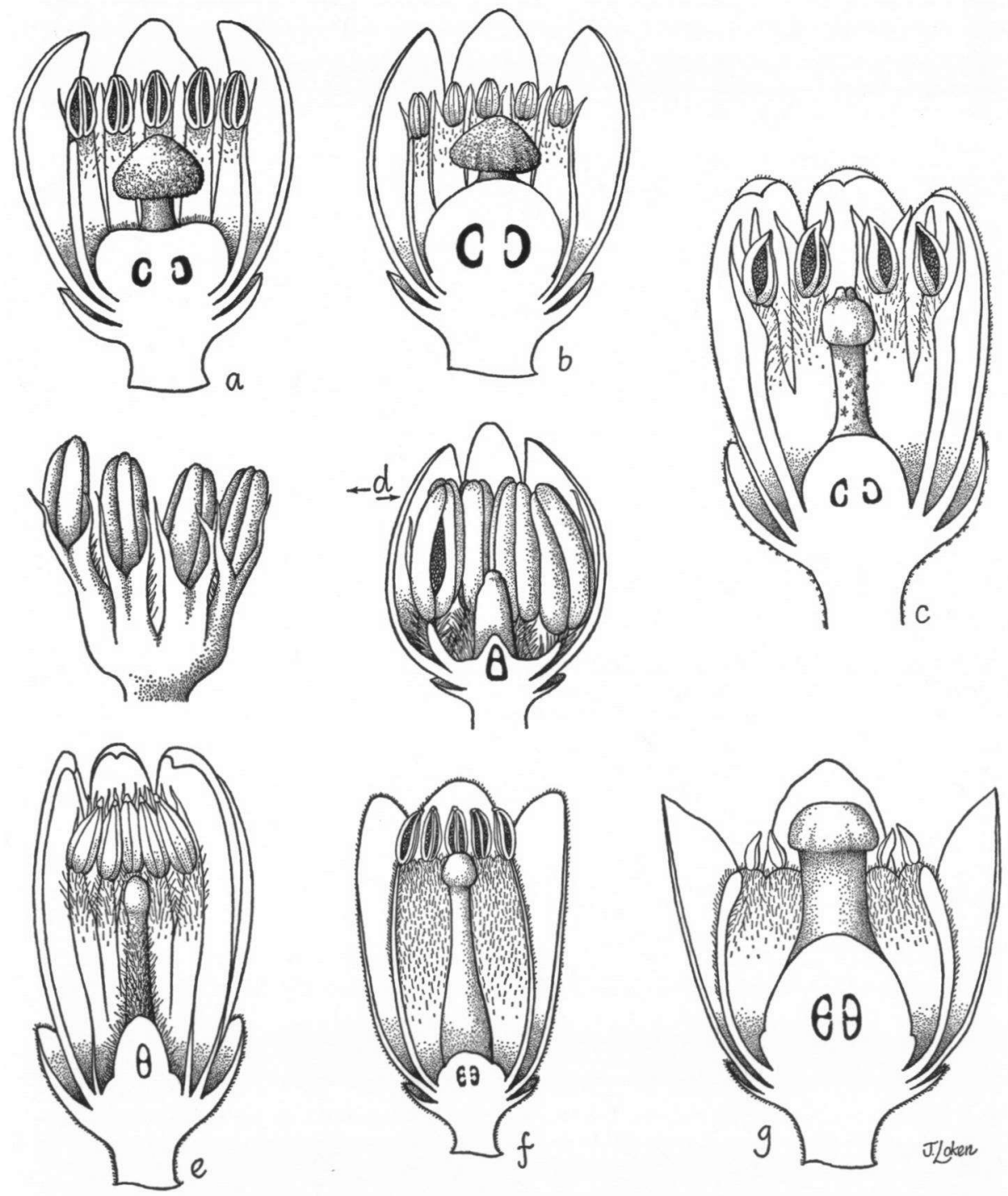

Fig. 7. 2. Walsura chrysogyne (Miq.) Bakh., $\sigma^{\circ} \times$ 10; b. ditto, $+9 \times$ 10. - c. Lepidotrichilia volkensii (Gürke) J. F. Leroy, 우, $\times$ 10. - d. Malleastrum gracile J. F. Leroy, ơ, $\times 20$. - e. M. sp. + , $\times 1$ s. - f. Ekebergia capensis Sparrm., \$, X7.5; g. ditto, 9 , $\times$ Is. (a. Pennington 7907; b. Pennington 7831; c. Styles 180; d. Decary 1573; e. R.N. 2930; f. White 8212; g. White 8146). 
species of Trichilia, T. cuneifolia (L.) Urb. from the West Indies, and stellate indumentum occurs in only a few species of Trichilia.

The relationship of Lepidotrichilia with Astrotrichilia is discussed under the latter.

\section{MALLEASTRUM}

Malleastrum (Baill.) J. F. Leroy, Journ. Agr. Trop. Bot. Appl. II (1964) 128. - Fig. 7d, e. Cipadessa sect. Malleastrum Baill., Adansonia II (1874) 256.

Trichilia sect. Eutrichilia C. DC., Bull. Herb. Boiss. II, I (I90I) 563 , pro parte, quoad T. mocquersii C. DC., T. obtusifolia C. DC. tantum.

Trichilia sect. Pterotorhachis Harms in Engl. \& Prantl, Nat. Pflanzenfam. ed. 2, 19 bI (I940) 116.

Trees or shrubs. Indumentum of simple hairs. Leaves imparipinnate, trifoliolate, or unifoliolate, the rhachis sometimes winged. Flowers bisexual or unisexual, in small axillary panicles. Calyx 4-6-lobed to halfway or below, or almost truncate. Petals (3)s or 6, free, valvate. Filaments $0.125-0.7 \mathrm{~cm}$ long, connate in the lower half or to above halfway, terminated by a pair of narrowly lanceolate or filiform appendages, or completely fused to form a cyathiform or shortly cylindrical staminal tube, the margin with (8) Io lanceolate, filiform, or shallowly to deeply bifid appendages alternating with the anthers. Anthers (8) ro, hairy or glabrous, inserted between the appendages. Antherodes narrower, rather shrunken, not dehiscing, without pollen. Disk annular, hairy or rarely glabrous, fused to the base of the ovary, or absent. Ovary I-3(s)-locular; loculi with 2 superposed or slightly oblique ovules. Style-head capitate, surmounted by a minute stigma with an apical depression. Fruit a $\mathrm{I}-3$ (s)-locular berry, often asymetrical, the loculi I-seeded; pericarp thin-fleshy. Seed oblong or spheroidal, exarillodiate. Testa thin and membraneous or sometimes thickened and rather hard. Endosperm absent. Embryo with plano-convex, collateral or oblique cotyledons. Radicle superior, included or extending to the surface.

P oll e n: Pollen grains (3)4-colporate, spheroidal, prolate-spheroidal, or subprolate $(30-40 \mu \mathrm{m}$; amb rounded or quadrangular). Apocolpium medium to large. Short colpi transversales sometimes present. Ora circular or lalongate. Exine thick or medium, smooth to slightly scabrous, thickened at the apertures.

$S$ e c o n d a r y $x$ y l e m: Vessels: solitary and in radial rows of 2-s; tangential diameter $20-60 \mu \mathrm{m}$; intervascular pits $3 \mu \mathrm{m}$; gum present. Ray tissue: uniseriate-homogeneous or -heterogeneous; rays up to 20 cells high, the heterocellular with I marginal row. Fibres: non-septate. Parenchyma. Paratracheal: vasicentric, of mainly scattered cells, occasionally aliform. Apotracheal: bands present, with crystals. Diffuse cells present, usually crystalliferous.

$\mathrm{D}$ i $\mathrm{t} \mathrm{rib}$ u $\mathrm{t}$ i o $\mathrm{n}$ : About $\mathrm{I2}$ species in Madagascar and the Comores.

T y p e s pe ci es: $M$. boivinianum (Baill.) J. F. Leroy.

Relationships: Baillon (I874), who was unaware of the nature of the fruit, placed the first two species to be described, $M$. boivinianum (Baill.) Leroy and $M$. depauperatum (Baill.) Leroy, in the section Malleastrum of Cipadessa. C. de Candolle (1878) followed Baillon, but later described three further species under Trichilia. In the first edition of Die Natürlichen Pflanzenfamilien (I 896) Harms followed Baillon, but in the second (1940) largely followed De Candolle, although he created a new section Pterotorhachis for Trichilia ramiflora $\mathrm{C} \cdot \mathrm{DC}$.

Malleastrum differs from Cipadessa in the following characters: loculi with superposed ovules (loculi uniovulate or rarely with 2 collateral ovules in Cipadessa); the fruit is a I-3(s)-seeded berry with a thin fleshy pericarp (a drupe with $s$ pyrenes, endocarp bony, in Cipadessa); the seed is exendospermous (endospermous in Cipadessa); the embryo has 
plano-convex cotyledons with a short included radicle (cotyledons thin, flat; radicle long exserted in Cipadessa). In addition to these diagnostic characters, Malleastrum differs in the structure of the disk, when present, and the ovary, which is usually I-3-locular compared with s-locular in Cipadessa; the fruit of Malleastrum is generally I-seeded, (5 pyrenes, each I(2)-seeded in Cipadessa).

Cipadessa has very distinct secondary xylem and differs from Malleastrum in having very heterogeneous ray tissue (rays with $I-6$ rows of marginal cells), septate fibres, and no diffuse parenchyma cells.

Malleastrum can be distinguished from Trichilia by its baccate fruit with an exarillodiate seed. The free valvate corolla lobes, constant in Malleastrum, are known only from one species of Trichilia (T. cuneifolia (L.) Urb.).

In gross morphology this genus appears to be closer to Lepidotrichilia, from which it differs in the simple indumentum and two superposed ovules in each locule (locule uniovulate in Lepidotrichilia). Differential characters often occurring in Malleastrum but never in Lepidotrichilia are the usually unilocular ovary and well marked annular disk. The structure of the secondary xylem also confirms that Malleastrum is closely related to Lepidotrichilia.

Malleastrum differs from Walsura in having loculi with 2 superposed ovules (loculi uniovulate or with two collateral ovules in Walsura). A character often present in Malleastrum but never in Walsura is the unilocular ovary. Malleastrum always has valvate aestivation of the corolla, whereas in Walsura it is imbricate or rarely contorted except in $W$. robusta Roxb. and very rarely in $W$. pinnata Hassk. The style-head of Malleastrum is always minute-capitate, usually no broader than the style, whereas that of Walsura is more developed and generally truncate or pileate. The seed of Malleastrum is always exarillodiate, while that of Walsura usually has an arillode. All species of Walsura except $W$. chrysogyne (Miq.) Bakh. $f$. have pulvinate petiolules, a character never present in Malleastrum.

\section{I6. EREBERGIA}

Ekebergia Sparrm., Svenska Vet. Akad. Handl. Stockh. 40 (1779) 282, t. 9; Harms in Engl. \& Prantl, Nat. Pflanzenfam. ed. 2, 19 bI (1940) 119, t. 29. - Fig. 7 f, g.

Charia C. DC., Bull. Soc. Bot. France Mém. 8 (1907) 9.

Trichlia sect. Pterotrichilia Harms in Engl. \& Prantl, Nat. Pflanzenfam. ed. I, 3(4) (1896) 307.

Trees or shrubs. Indumentum of simple hairs. Leaves imparipinnate. Flowers unisexual (plant dioecious), in axillary or supra-axillary thyrses.Calyx 4-or $5(6)$-lobed in the upper half. Petals 4-6, free, imbricate. Staminal tube $0.15-0.5 \mathrm{~cm}$ long, urceolate to shortly cylindrical, filaments completely fused or connate just below the apex; margin of staminal tube without appendages. Anthers 8- $\mathrm{IO}\left(\mathrm{r}_{3}\right)$, hairy or glabrous, inserted on the rim of the staminal tube; antherodes very slender, not dehiscing, without pollen. Disk in male flowers annular or patelliform, partially fused to the base of the staminal tube and ovary; in female flowers represented by a small swelling fused to the base of the swollen ovary. Ovary 2-5(6)-locular; loculi with 2 superposed ovules; style short and stout; style-head capitate or thick discoid, with $2-5(6)$ small incurved stigmatic lobes and a central depression; pistillode with a slender vestigial ovary containing loculi and small ovules; style longer. Fruit a drupe with 2-5(6) pyrenes, each I(2)-seeded; endocarp thin, woody or cartilaginous. Seed shaped like the segment of an orange; exarillodiate; testa thin. Embryo surrounded by fleshy endosperm or seed exendospermous; cotyledons plano-convex, collateral; radicle superior, short, slightly exserted.

$\mathrm{G}$ e $\mathrm{r} \mathbf{m}$ i n a $\mathrm{t}$ i o $\mathrm{n:}$ : phanerocotylar or cryptocotylar; eophylls opposite, trifoliolate or pinnate, the rhachis winged. 
Chromosome numbers: $2 n=46,50$.

P o 11 e n: Pollen grains 4(s)-colporate, oblate-spheroidal, spheroidal, prolatespheroidal, or subprolate (25-40 $\mu \mathrm{m}$; amb rounded). Apocolpium medium to small. Colpi often shortly bifurcate. Ora circular or lalongate. Exine smooth to scabrous, slightly thickened at the apertures.

S e c ondar y x y l e m: Vessels: solitary and in radial groups of $2(3)$; tangential diameter 100-140 $\mu \mathrm{m}$; intervascular pits $7.5 \mu \mathrm{m}$; gum present. Ray tissue: homogeneous Kribs Type I; rays 2 or 3-seriate, up to 30 cells high. Fibres: non-septate. Parenchyma. Paratracheal: vasicentric. Apotracheal: terminal bands present. Diffuse crystalliferous cells present. The amount of apotracheal parenchyma varies from widely spaced, narrow terminal bands to abundant broad bands.

$\mathrm{D}$ is $\mathrm{t} \mathbf{r} \mathrm{i}$ b u $\mathrm{t}$ i o $\mathrm{n:}, 4$ species in Africa.

$T$ y pe s p e c i es: $E$. capensis Sparrm.

Relationships: Ekebergia differs from Trichilia in its indehiscent drupaceous fruit which contains exarillodiate seeds without a sarcotesta. Ekebergia may be distinguished from Lepidotrichilia by the simple indumentum (stellate in Lepidotrichilia); imbricate aestivation of the corolla (valvate in Lepidotrichilia); annular or patelliform disk (disk absent in Lepidotrichilia); biovulate loculi (uniovulate in Lepidotrichilia.)

The secondary xylem of Ekebergia differs from that of Trichilia and Lepidotrichilia in its large intervascular pits (7.5 $\mu \mathrm{m}$ diameter). The rays are also broader (2- or 3-seriate) than in these two genera except for those of the two Asiatic species of Trichilia.

\section{I7. ASTROTRICHILIA}

Astrotrichilia (Harms) J. F. Leroy, Compt. Rend. Acad. Sci. Paris 247 (1958) 1889; Journ. Agr. Trop. Bot" Appl. 5 (1958) 861. - Fig. 8a.

Trichilia sect. Astrotrichilia Harms in Engl. \& Prantl, Nat. Pflanzenfam. ed I, 3 (4) (1896) 306.

Trichilia sect. Peltotrichilia Harms, op. cit. ed. 2, 19 bl (1940) III.

Trees with stellate indumentum at least on the young parts. Leaves pinnate or trifoliolate. Flowers bisexual or unisexual, in axillary thyrses or panicles. Calyx shallowly to deeply s-lobed; aestivation open or imbricate. Petals 5 , free, imbricate. Staminal tube $0.05-0.15 \mathrm{~cm}$ long, cyathiform, the margin almost entire or with $10(\mathrm{II})$ narrow lanceolate teeth bearing the anthers. Anthers Io(I I), hairy or glabrous. Antherodes similar, not dehiscing, without pollen. Disk patelliform, fused to the base of the staminal tube, or absent. Ovary 2-5-locular; loculi with 2 usually superposed or rarely collateral ovules. Style-head thick, discoid. Fruit a I-3-locular drupe; loculi I-seeded; mesocarp thin and fleshy; endocarp thick, woody, with a cartilaginous inner face, sometimes with loculicidal dehiscence. Seed radially compressed, exarillodiate, with an indistinct sarcotesta. Embryo surrounded by thick endosperm; cotyledons thin, flat, collateral; radicle abaxial, small, slightly projecting.

P oll e n: Pollen grains $4(5)$-colporate, prolate-spheroidal or subprolate (c. $45 \mu \mathrm{m}$; amb rounded or angular). Apocolpium medium to large. Ora lalongate. Exine smooth or scabrous, thickened at the apertures.

S e c ondar y x y l e m: Vessels: solitary and in radial rows of 2-4(7); tangential diameter 40-160 $\mu \mathrm{m}$; intervascular pits $4.5-6 \mu \mathrm{m}$; gum present. Rays tissue: homogeneous Kribs Type I or uniseriate homogeneous; rays I or 2-seriate, up to 25 cells high. Fibres: non-septare or occasionally septate; with prominent bordered pits in the radial walls. Parenchyma: Paratracheal: sparse vasicentric, consisting entirely of scattered cells. Apotracheal: bands present with abundant crystals. Diffuse crystalliferous cells present. 
$\mathrm{D}$ is $\mathrm{t} \mathrm{r}$ i b u t i o n: About $\mathrm{r}_{4}$ species in Madagascar.

T y p e s p e ci es: $A$. asterotricha (Radlk.) J. F. Leroy.

$\mathrm{Re}$ lat $\mathrm{i}$ o $\mathrm{n}$ s $\mathrm{h}$ i s: In its morphology and anatomy this genus is most closely allied to the endemic Australian genus Owenia, under which the relationships are discussed. It is also related to Ekebergia and Lepidotrichilia, though not so closely. It differs from Ekebergia in its stellate indumentum (simple in Ekebergia); thick woody endocarp (thin in Ekebergia), and its radially compressed seeds with a sarcotesta (seeds shaped like the segment of an orange and without a sarcotesta in Ekebergia). The embryo is surrounded by copious endosperm, which is known for only one species of Ekebergia. All these characters except the stellate indumentum, also distinguish Astrotrichilia from Lepidotrichilia, and in addition the latter genus has valvate aestivation of the corolla.

The secondary xylem of Astrotrichilia is similar to that of Lepidotrichilia, but can be distinguished by the large bordered pits in the radial walls of the fibres. The broader rays and larger intervascular pits of Ekebergia are sufficient to distinguish this genus.

\section{OWENIA}

Owenia F. Muell. in Hook. Kew Journ. Bot. 9 (1857) 303; Harms in Engl. \& Prantl, Nat. Pflanzenfam. ed. 2, I9 bI (1940) I22 - Fig. 8b, c.

Trees with paripinnate leaves. Indumentum of simple hairs. Flowers unisexual (plant dioecious), in axillary panicles. Caly $x$ of 5 free imbricate sepals. Petals 5 , free, imbricate. Staminal tube $0.1-0.3 \mathrm{~cm}$ long; margin irregularly lobed, the lobes forming a frill, or filaments free in the upper half and terminated by 2 narrowly lanceolate appendages. Anthers ro, glabrous, inserted inside the margin of the staminal tube or apically between the filament appendages; antherodes slender, indehiscent, without pollen. Disk small, annular, fused to base of ovary. Ovary 2- or 3(4)-locular; loculi uniovulate; in male flowers ovary smaller, not at all swollen, with vestigial ovules. Style abruptly expanded at the apex to form a shallow disk bearing a large conical 2- or 3-lobed stigma. Fruit a 2- or 3-locular drupe; mesocarp thin, leathery or fleshy, endocarp very thick, hard, and woody. Seed shaped like the segment of an orange, depressed or ovoid, exarillodiate, with a complete thin sarcotesta. Embryo surrounded by thin endosperm; cotyledons plano-convex, collateral; radicle superior, short, slightly exserted or extending to the surface.

G e rm in a t i o $n^{\star}$ : phanerocotylar; eophylls opposite, pinnate; rhachis winged (O. reticulata F. Muell., O. vernicosa F. Muell.).

Chromosome n u m ber: $2 n=28$ (O. acidula F. Muell.) (Styles \& Khosla, in press).

P oll e n: Pollen grains 4- or 5 -colporate, subprolate or prolate $(30-40 \mu \mathrm{m}$; amb rounded). Apocolpium large or medium. Ora circular or lalongate. Exine smooth or scabrous, usually slightly thickened at the apertures.

S e c ond a r y $x$ y l e m: Vessels: solitary and in radial rows of 2 or $3(8)$, sometimes with pore clusters; tangential diameter $60-160 \mu \mathrm{m}$; intervascular pits $3.75-4.5 \mu \mathrm{m}$; gum present. Ray tissue: heterogeneous Kribs Type 3 or homogeneous Kribs Type 1 or 2; rays (1)2-5-seriate, up to 35 cells high, the heterocellular with I marginal row; sometimes the rays are almost storied. Fibres: non-septate. Parenchyma: Paratracheal: vasicentric and aliform, sometimes confluent. Apotracheal: terminal bands present, with crystals. Diffuse crystalliferous cells abundant.

^Information kindly supplied by David Symon Esq., Waite Agricultural Research Institute, Glen Osmond, S. Australia. 


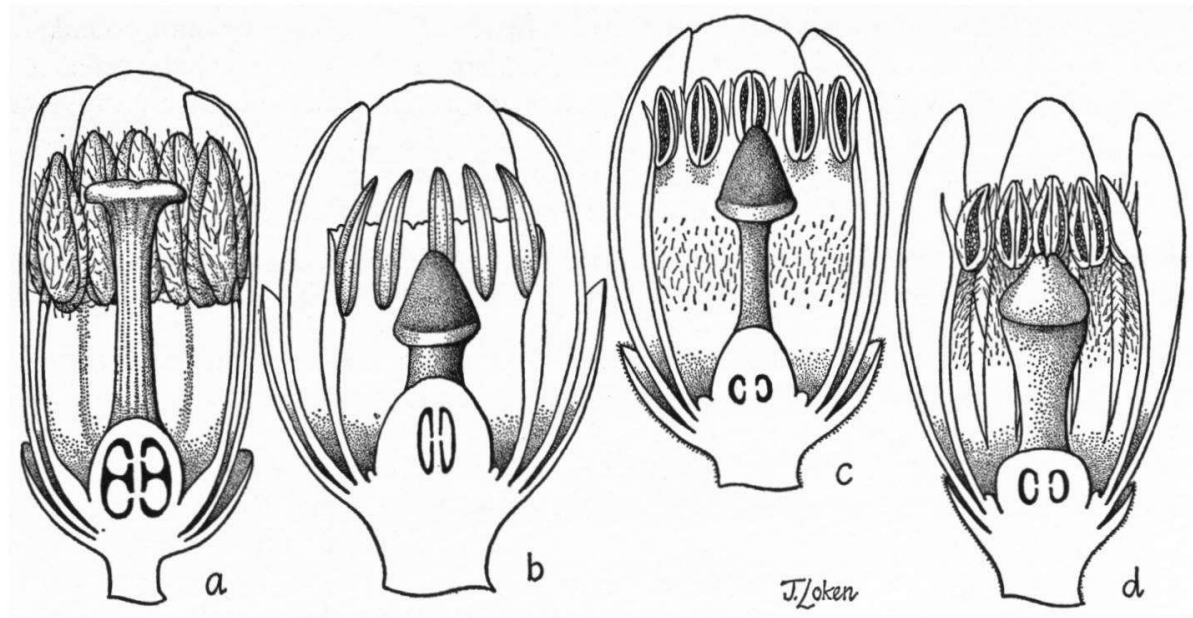

Fig. 8. a. Astrotrichilia sp., ㅇ, $\times$ Is.- b. Owenia acidula F. Muell., ㅇ, $\times 1$ s. - c. O. reticulata F. Muell., đँ. $\times 15 .-$ d. Cipadessa fruticosa Bl., §ิ, X25. (a. Capuron 11319; b. Smith s.n.; c. Borden s.n.; d. Rao 18604).

$\mathrm{D}$ is $\mathbf{t} \mathbf{r}$ i b u t i o n: About six species in eastern Australia.

T y pe s p e ci es: $O$. acidula F. Muell. (here chosen as lectotype).

$\mathrm{Rel}$ a tions hips: This genus is closest to Astrotrichilia. It can, however, be distinguished on a number of characters. These are the simple indumentum, the form of the staminal tube with appendages, the uniovulate loculi, the form of the stigmatic lobes, and the plano-convex fleshy cotyledons with a superior radicle. The shape of the disk also provides distinction between these two genera.

The seeds of species in the genus have proved almost impossible to germinate.

\section{I9. CIPADESSA}

Cipadessa Blume, Bijdr. (1825) 162; Harms in Engl. \& Prantl, Nat. Pflanzenfam., ed. 2, 19 bI (1940) 93. t. 21, figs. A-D. - Fig. 8d.

Mallea A. Juss., Mém. Mus. Hist. Nat. Par. 19 (1830) 221.

Small trees or treelets with imparipinnate leaves. Indumentum of simple hairs. Flowers bisexual and unisexual on the same individual (polygamous), in axillary panicles. Calyx 5 -lobed in the upper half. Petals 5 , free, valvate. Filaments $0.15-0.25 \mathrm{~cm}$ long, connate near the base, terminated by a pair of narrowly lanceolate to filiform appendages. Anthers 1o, hairy, acute or apiculate, inserted between the appendages. Disk patelliform, fused to the base of the staminal tube. Ovary $5(6)$-locular; loculi with $\mathrm{I}(2)$ collateral ovules. Style short, stout, columnar, terminated by a swollen capitate style-head with $s$ small, stigmatic lobes. Fruit a small globular drupe with 5 pyrenes, each I(2)-seeded. Endocarp bony. Seed shaped like the segment of an orange, exarillodiate; testa thin, membraneous. Embryo surrounded by copious endosperm; cotyledons thin, flat, collateral; radicle superior, long exserted.

Germination: phanerocotylar; eophylls opposite or subopposite, ternate or trifoliolate. (C. baccifera (Roth) Miq.)

Chrom os om nu m bers: $2 n=28,56$. 
P o ll e n: Pollen grains 4(5)-colporate, prolate-spheroidal ( $30-40 \mu \mathrm{m}$; amb rounded). Apocolpium large. Ora lalongate. Exine smooth, slightly thickened at the apertures.

$S$ e c o n d a r y x y l e m: Vessels: in radial rows of 2-4; tangential diameter 60-120 $\mu \mathrm{m}$; intervascular pits $3.75 \mu \mathrm{m}$; gum present. Ray tissue: uniseriate-heterogeneous; rays $I(2)$-seriate, up to 30 cells high, the heterocellular with $I-6$ marginal rows; often composed entirely of upright cells. Fibres: septate. Parenchyma: Paratracheal: sparse vasicentric. Apotracheal: terminal bands present, with crystals.

$\mathrm{D}$ i s $\mathrm{t} \mathbf{r}$ i b u $\mathrm{t}$ i o $\mathrm{n}$ : One or two species in the Indo-Malayan region.

T y p e s p e ci es: C. fruticosa Bl. (equals C. baccifera (Roth.) Miq.).

R e lat i ons h i ps: Harms placed Cipadessa in the tribe Turraeeae next to Munronia, on account of the endospermous seed and embryo with exserted radicle. Endospermous seeds are now known to occur sporadically in other genera of the Melioideae, e.g. in Ekebergia pterophylla (C.DC.) Hofm. and some species of Trichilia. This fact alone would not provide sufficient ground for removing Cipadessa from the Turraeeae, but other vegetative, floral, fruit, and pollen characters indicate that it is incorrectly placed there and that it is more closely related to Ekebergia, Astrotrichilia, and Walsura in the Trichilieae.

The secondary xylem, however, is very distinctive and unlike that of any other member of the Trichilieae in having septate fibres correlated with very heterogeneous ray tissue, and in this respect it is similar to Vavaea.

Walsura is similar to Cipadessa in the structure of the androecium, but differs in the annular disk surrounding the 2-4-locular ovary and in the fruit which is a fleshy berry.

Ekebergia differs in several characters. These are the imbricate aestivation of the corolla, the entire staminal tube without appendages, and the superposed ovules.

Both Owenia and Astrotrichilia differ in having imbricate corolla lobes, filaments which are fused in the upper half or completely, in the shape of the style-head, and in the extremely thick bony endocarp of the fruit.

The relationships of Cipadessa with Malleastrum are discussed under the latter.

Tribus Aglaieae, tribus nova.

Tribe s. AgLATEAE

Folia fere pinnata. Indumentum fere stellatum vel ex squamis peltatis constans. Tubus stamineus fere globularis vel cyathiformis, semper appendicibus carens. Discus nullus. Fructus fere baccatus. Semina fere sarcotesta, rarius arillodio praedita; endospermium nullum. Cotyledones fere superpositae; radicula inclusa.

Typus tribus: Aglaia.

Leaves usually pinnate, rarely trifoliolate or unifoliolate. Indumentum usually of stellate or simple hairs or of peltate scales. Flowers hermaphrodite or unisexual (plants dioecious). Staminal tube usually globular or cyathiform, always without appendages. Disk absent. Fruit usually a berry. Seeds usually with a sarcotesta, less frequently arillodiate; without endosperm. Cotyledons usually superposed; radicle included.

P o 11 e n: Usually subprolate or prolate, very small (Io-30 $(35) \mu \mathrm{m}$ ); usually 3-colporate; exine usually smooth.

S e c o n d a r y x y l e m. Fibres septate; apotracheal terminal bands usually absent; paratracheal parenchyma aliform, confluent, and banded.

1. Anthers in a single whorl; indumentum of stellate or simple hairs or peltate scales.

2. Cotyledons free, nearly always superposed.

3. Indumentum of stellate hairs or peltate scales; inflorescence nearly always axillary, usually a panicle; petals $3-6$; ovary I-3(4)-locular; style very short or absent, style-head small, capitate, clavate, or conical, sometimes lobed; fruit usually a berry, less frequently a nut or capsule . . . . 20. Aglaia 
3a. Indumentum of simple hairs; flowers cauliflorous or ramiflorous; inflorescence nearly always a simple or compound spike, rarely a raceme; petals s; ovary s-locular; style long and broad-columnar, gradually tapering to the truncate style-head; fruit a berry . . . . . . . . . . 21. Lansium Cotyledons completely fused, collateral; indumentum usually of simple hairs (stellate in one species); inflorescence nearly always a long spike or panicle with spicate branches; petals 3; ovary 3(4)-locular, loculi mostly biovulate; fruit a capsule .............. 22. Aphanamixis 1a. Anthers in 2 alternating whorls of $s$; indumentum of simple hairs.

4. Fruit a berry; petals fused to staminal tube at the base; anthers of lower whorl with short acute connective appendages; seed exarillodiate, usually with a sarcotesta; cotyledons superposed, free . . . . . . 23. Reinwardtiodendron

4a. Fruit a capsule; petals free from staminal tube; anthers without connective appendages; seed arillodiate; cotyledons collateral, completely fused 24. Sphaerosacme

\section{AGLAIA}

Aglaia Lour., Fl. Cochinch. (1790) 173, nom. conserv. (Aglaia Lour. is conserved against Aglaia Allamando Nova Act. Acad. Leop. - Carol 4, 1770, 93, Cyperaceae); Harms in Engl \& Prantl, Nat. Pflanzenfam., ed, 2, 19 bI (1940) 140, t. 31, figs. A-Q - Fig. 9a-f.

Camunium Rumph. [Herb. Amb. $s$ (1747) 26, t. I8 E. I] ex Roxb., Fl Ind. 2 (1824) 425, non Adans. (1763) (=Murraya Koen. ex L.).

Amerina Noronha, Verh. Bat. Gen. $5(2)$ (1790) 64, nom. nud., non Rafin. (1838) nec DC. (1840).

Andersonia Roxb., Hort. Beng. (1814) 87, nom. nud., pro parte quoad A. cucullata Roxb. tantum; Fl. Ind. ed. 2, 2 (1832) 212, pro parte., non R. Br. (1810) nec Willd. ex Roem. \& Schult. (1819).

Milnea Roxb. [op. cit. (1814) 18, nom. nud.] Fl. Ind. ed. Carey \& Wall. 2 (1824) 430, non Rafin. (1838). ?Nyalelia Dennst., Schluissel Hort. Malabar. (1818) 30.

Amoora Roxb., Pl. Coromandel 3 (1819) 54, t. 258; Harms tom. cit. 128.

Nemedra A. Juss., Mém. Mus. Hist. Nat. Par. I9 (?1830) 223.

Argophilum Blanco, Fl. Filip. (1837) I86 ('Argopyilum'), non Argophyllum Forst. (1776).

Selbya M. Roem., Synops. Hesp. Monogr. I (1846) 89, 126.

Nimmoia Wight, Calc. Joum. Nat. Hist. 7 (1847) 13, non Wight (1837).

Euphora Griff., Notul. 4 (1854) 547.

Oraoma Turcz., Bull. Soc. Nat. Mosc. 31 (1858) 411.

Beddomea Hook. $f$. in Benth. \& Hook. $f$, Gen. Pl. I (1862) 336.

Hearnia F. Muell., Fragm. 5 (1865) 55.

Aglaiopsis Miq., Ann. Mus. Bot. Lugd. Batav. 4 (1868) 58.

Lepiaglaia Pierre, Fl. Forest. Cochinch. sub t. 334 (1895), sub t. 352 (1896).

Merostela Pierre, op. cit. sub t. 334 (1895), sub t. 342 (1896).

Trees or treelets with pinnate or rarely trifoliolate or unifoliolate leaves. Indumentum of stellate hairs or peltate scales at least on the young parts. Flowers unisexual (plants dioecious), usually in axillary panicles, rarely cauliflorous; male inflorescence large and manyflowered, female smaller, fewer-flowered and sometimes reduced to a short spike. Female flowers often much larger than the male. Calyx shallowly or deeply (2) 3 -5-lobed; aestivation open or imbricate. Petals $3-6$, free or united below, free from the staminal tube or partially united to it, imbricate. Staminal tube $0.05-0.55 \mathrm{~cm}$ long, globose, urceolate, campanulate, cyathiform, or rarely shortly cylindrical, the throat open or constricted, with an entire or crenate or rarely lobed margin. Anthers (3) 5 - Io(I9), glabrous or rarely hairy, inserted in a single whorl in the lower or upper half of the staminal tube or on the margin. Antherodes similar, without pollen. Disk absent. Ovary I-3(4)locular; loculi with I or 2-collateral or superposed ovules. Style short or absent. Stylehead usually small, capitate, conical, or clavate, sometimes with 3 or 4 small lobes. Pistillode usually minute, ovules very small or absent. Fruit a $\mathrm{I}-4(6)$-seeded berry, nut, or 
less frequently a 2- or 3-valved loculicidal capsule. Seed arillodiate or less frequently with a sarcotesta; arillode fleshy, free or partly fused, partly or completely surrounding the seed; sarcotesta fleshy, often vascularized. Embryo with thick, plano-convex, superposed or very rarely oblique to collateral, free cotyledons; radicle included.

Germin a t i on: cryptocotylar, eophylls usually opposite, sometimes spirally arranged, simple or trifoliolate, margin entire ( $A$. sp., KEP FRI. 15187, Malaya; $A$. odoratissima B1., A. eusideroxylon Koord. \& Valet. (Burger, 1972)).

Ch r o m o s o m e n u m bers: $\mathrm{n}=20,40 ; 2 \mathrm{n}=92$.

P o ll e n: Pollen grains 3(4)-porate or-colporate, subprolate or prolate, rarely spheroi$\mathrm{dal}$ (10-30 $\mu \mathrm{m}$; amb rounded or triangular). Apocolpium large. Ora circular or lalongate, rarely crassimarginate. Exine smooth or rarely minutely scabrous, thickened at the apertures.

$S$ e c o n d a r y x y l e m: Vessels: solitary and in radial groups of 2-8, rarely showing an oblique pattern; tangential diameter $40-300 \mu \mathrm{m}$; intervascular pits $1.5-4.5 \mu \mathrm{m}$; gum present or absent. Ray tissue: usually heterogeneous Kribs Type 3, homogeneous Kribs Type I, or uniseriate-heterogeneous, more rarely heterogeneous Kribs Type 2, homogeneous Kribs Type 2 or uniseriate homogeneous; rays I or $2(4)$-seriate, up to 40 cells high, the heterocellular with I(3) marginal rows. Fibres: septate. Parenchyma. Paratracheal: vasicentric, aliform, confluent and often banded, with crystals (the latter very rarely absent). Apotracheal: terminal bands usually absent, very rarely present. Diffuse crystalliferous cells occasionally present.

$\mathrm{D}$ i s $\mathrm{t} \mathrm{r}$ i b u t i o n: About 100 species in the Indo-Malesian region, Australia, Melanesia, and Polynesia.

T y pe s p e ci es: $A$. odorata Lour.

$\mathrm{Re}$ l a t i on sh i ps: Aglaia has more synonyms than most genera in the Melioideae, due to the considerable variation within it. The majority of species are similar to the type $A$. odorata Lour. in having the following combination of characters: 5 petals; 5 anthers inserted within the throat of the staminal tube; a bilocular ovary; a baccate fruit. Since Loureiro described the type species, a number of closely related genera have been described which differ from typical Aglaia in single features, e.g. Milnea has a 3-locular ovary; Hearnia has the anthers inserted on the margin of the staminal tube; Beddomea has a capsular fruit. It can be easily demonstrated that intermediates exist, e.g. many species have a 2 or 3-locular ovary, and that there is no justification for maintaining these genera.

The type of Amoora, A. cucullata Roxb., differs from typical Aglaia in more respects; it has 3 petals, $6-8$ anthers, a 3-locular ovary, and a capsular fruit. Since $A$. cucullata was described, other, less extreme species have been discovered which provide connecting links, so that it is now impossible to recognize Amoora as a distinct entity. Various authors have maintained Amoora on the basis of single characters. C. de Candolle (1878) emphasized the number of anthers, King (1895) the number of petals, and Harms (I940) considered dehiscence of the fruit to be most important. Because these characters are not completely correlated, the circumscription of Amoora differs according to which character is emphasized, and none is satisfactory. Pellegrin (1909), one of the few authors who has united Amoora with Aglaia, gives a detailed account of the gradation of morphological characters between the two groups, though later (1946: 48) he apparently had second thoughts, again without stating his reasons.

Characters of the secondary xylem show similar intergradation. Typical Aglaia has I or 2-seriate rays and a mixture of confluent and banded parenchyma, whereas typical Amoora has 2- or 3-seriate rays with vasicentric and aliform parenchyma. Aglaia argentea Bl. has 2-seriate rays with aliform parenchyma; Amoora cucullata Roxb. has I- or 2-seriate rays with aliform and confluent parenchyma. 
The relationships of Aglaia with Lansium, Reinwardtiodendron, and Aphanamixis are discussed under those genera.

\section{LANSIUM}

Lansium Rumph. [Herb. Amb. I (I74I) I5I, t. 54] ex Corr., Ann. Mus. Hist. Nat. Paris Io (I807) I57, t. Io fig. I; Harms in Engl. \& Prantl, Nat. Pflanzenfam., ed. 2, I9 bI (I940) 123, t. 30, figs. J-P, pro parte quoad sectio Eulansium tantum. - Fig. $9 \mathrm{~g}$, h.

[Plutea Noronha, Verh. Batav. Gen. 5 (2) (1790) 64, nom. nud.]

[Lachanodendron Reinw. ex Blume, Cat. Gew. Buitenzorg (1823) 70, nom. nud.]

Aglaia sect. Lansium (Corr.) Kosterm., Reinwardtia 7 (1966) 221 pro parte.

Trees with pinnate leaves. Indumentum of simple hairs. Ramiflorous; or occasionally cauliflorous, the flowers in spikes, or slender racemes, or panicles branched from the base with spicate branches. Flowers unisexual (plants dioecious) and bisexual, perfect flowers, larger than the male. Calyx deeply 5-lobed; lobes imbricate. Petals 5, free from each other, but fused to the staminal tube in the lower half; imbricate. Staminal tube $0.2-0.4$ $\mathrm{cm}$ long, globular to cyathiform, with an undulate or crenate margin. Anthers (8) ro, glabrous, inserted in a single whorl inside the throat of the tube and scarcely exserted beyond the rim. Disk absent. Ovary 5-locular; loculi uniovulate. Style long and broadcolumnar, not or only slightly expanded at the truncate style-head, the margin ribbed with the impression of the surrounding anthers. Pistillode more slender, (3) s-locular; ovules smaller. Fruit a I-5-seeded berry with soft pericarp. Seeds with a thick, fleshy, whitish arillode closely applied but not fused to the testa. Embryo with thick, planoconvex, superposed, free cotyledons; radicle included.

Ch rom os om e n u m b e r: $\mathrm{n}=72$ ( $L$. domesticum Corr.)

P o 11 e n: Pollen grains $3-5$-colporate, oblate-spheroidal ( $20-28 \mu \mathrm{m}$; amb rounded). Apocolpium large. Ora circular. Exine smooth or finely scabrous, thickened at the apertures.

S e condary x y l e m: Vessels: solitary and in radial rows of 2 or 3; tangential diameter $60-\mathrm{r} 20 \mu \mathrm{m}$; intervascular pits $3.75 \mu \mathrm{m}$; gum absent. Ray tissue: heterogeneous Kribs Type 3; rays I- or 2-seriate, up to 20 cells high, the heterocellular with I marginal row. Fibres: septate. Parenchyma. Paratracheal: confluent and banded, with crystals.

$D$ i s $t r$ i b u $t$ i o n: Probably $I-S$ variable species in western Malesia.

T y pe s pe c i es: $L$. domesticum Corr.

$\mathrm{Relat}$ i o n s ips: Lansium as accepted by Harms is heterogeneous, and his first section Eulansium, containing $L$. domesticum Corr. and its varieties, occupies an isolated position within it. Harms' second section, Neolansium (containing L. humile Hassk., L. cinereum Hiern, $L$. anamallayanum Bedd., and $L$. dubium Merr.) differs from Eulansium in the following characters: inflorescence axillary (ramiflorous or cauliflorous in Eulansium); anthers in two alternating whorls of five, the lower whorl with a short connective appendage (one whorl of 10 anthers without appendages in Eulansium); style very short with a small, capitate, and obscurely-lobed style-head (style long, columnar, not or only slightly expanded at the truncate style-head in Eulansium); corolla fused to the staminal tube at the base only (corolla fused for almost half its length to the staminal tube in Eulansium). As all the characteristics of section Neolansium mentioned above are shared by the genus Reinwardtiodendron, the species of this section are therefore transferred to the latter genus.

Harms' third section Pseudolansium contains the single species $L$. decandrum (Wall.) Harms which differs from the type in many floral and fruiting characters. In the present 

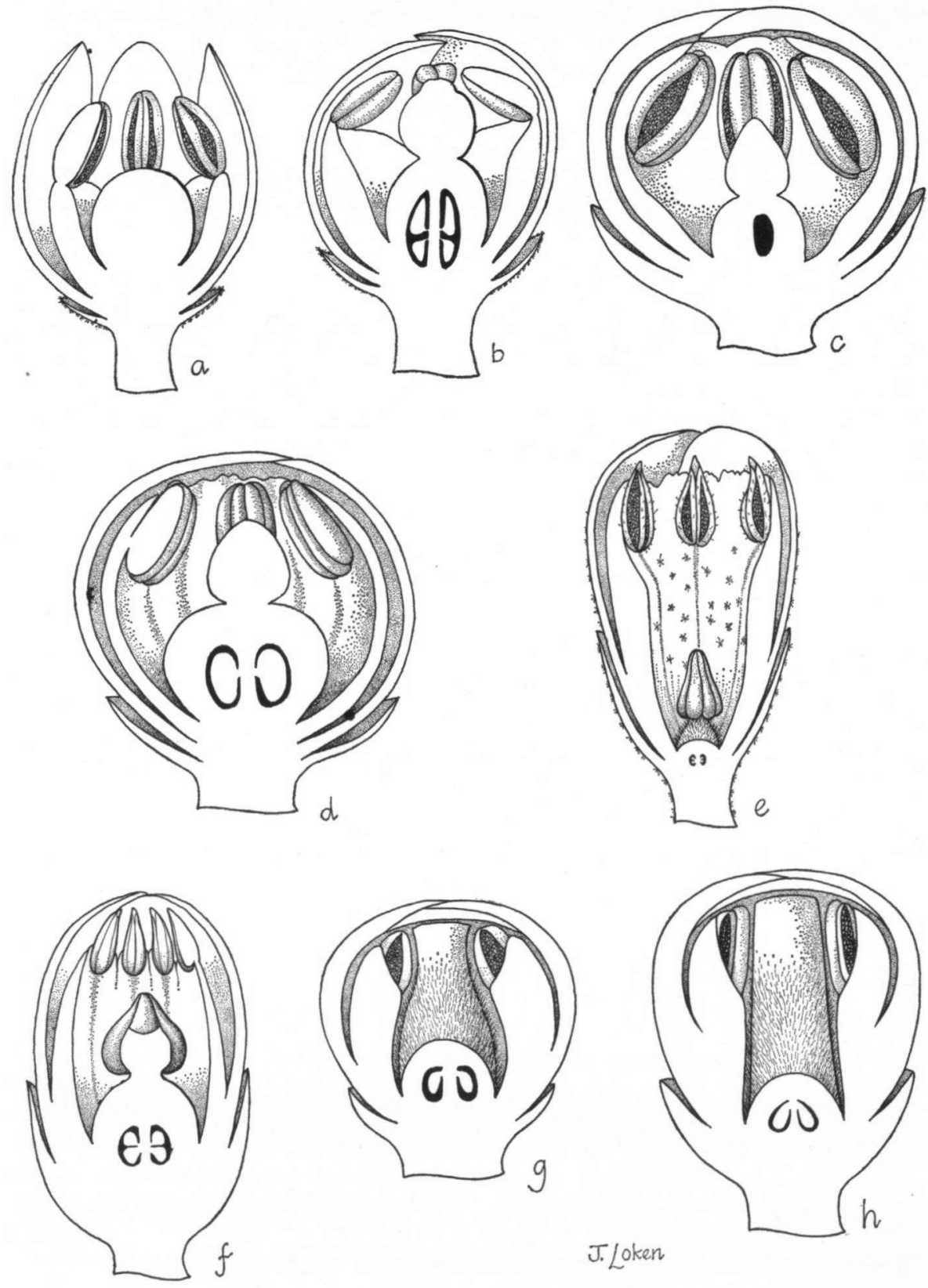

J.Loken

Fig. 9. 2. Aglaia sapindina (F. Muell.) Harms, $\sigma^{*}, \times 35$; b. ditto,, , $\times 25-c$. A. elaeagnoidea (A. Juss.) Benth.,

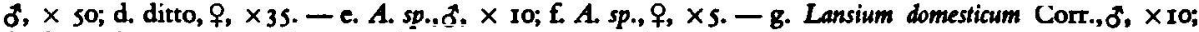
b. ditto, \&, $\times 7.5$. (2. Hollrung 25; b. N.G.F. 3133; c. Rahman 2694; d. Pennington 8130; e. Pennington 7903; f. Pennington 7902; g. Pennington 7972; h. Pennington 7989). 
work it is elevated to generic rank (Sphaerosacme). Its relationships are discussed in detail after the description.

Aglaia section Lansium of Kostermans (I966) is also heterogeneous and those species of it whose floral characters are known, can be confidently placed in either Lansium ( $A$. steenisii Kosterm., $A$. aquea (Jack) Kosterm., $A$. dookkoo Griff., $A$. domestica (Corr.) Pellegr., $A$. sepalina (Kosterm.) Kosterm. or Reinwardtiodendron (A. reinwardtiana Kosterm., $A$. pseudolansium Kosterm., A. kinabaluensis Kosterm., A. dubia (Merr.) Kosterm., A. anamallayana (Bedd.) Kosterm.). Flowering material is needed before the remaining five species described in Kosterman's monograph can be placed with certainty.

Lansium, as defined in the present work, is distinguished from Aglaia by its simple indumentum (not stellate or peltate); its 5-locular ovary ( $1-4$-locular in Aglaia), and by the structure of its style and style-head. Other features of Lansium which are rarely found in Aglaia are the ramiflory or cauliflory and the spicate inflorescence.

The secondary xylem of Lansium cannot be distinguished from that of some species of Aglaia. Its pollen morphology is, however, quite distinct, the 3-5-colporate, oblatespheroidal pollen grains differ from those of all known Aglaia species which are 3(4)colporate and nearly always prolate or prolate-spheroidal.

\section{APHANAMIXIS}

Aphanamixis Blume, Bijdr. (I825) I65; Harms in Engl. \& Prantl, Nat. Pflanzenfam., ed. 2, I9 bI (1940) 126 t. 30, fig. Q - Fig. Ion, b.

Andersonia Roxb. [Hort. Beng. (1814) 87 nom. nud., pro parte quoad A. rohituka Roxb. tantum] Fl. Ind. 2, (1832) 212, non R. Br. (1810) nec Willd. ex R. \& S. (1819).

[Sphaerosacme Wall., Num. List (I829) n. 1277 nom. nud., pro parte quoad S. polystachya Wall. tantum.] Aphanomyxis DC., Prod. 7 (2) (1839) 766.

[Chuniodendron Hu, Journ. Roy. Hort. Soc. 63 (1938) 387 in obs., nom. nud.]

Trees or treelets with pinnate leaves. Indumentum of simple or very rarely stellate hairs. Flowers unisexual (plant dioecious) or bisexual. Inflorescence axillary or supra-axillary, the male flowers in large panicles with spicate or rarely racemose branches, the female and hermaphrodite ones in long spikes or rarely in large panicles with spicate branches. Male flowers smaller than female and hermaphrodite. Calyx deeply 5-lobed; lobes imbricate. Petals 3, free, fused in the lower half to the staminal tube, imbricate. Staminal tube 0.15$0.45 \mathrm{~cm}$ long, globose or deeply cyathiform, the throat narrow or wide; margin entire or slightly crenate. Anthers $3-8$, glabrous, inserted within the throat in the upper or lower half of the staminal tube, completely included or partly exserted; connective sometimes produced to form a short terminal appendage. Antherodes indehiscent, without pollen. Disk absent. Ovary 3(4)-locular; loculi with (I)2 collateral to superposed ovules. Style very short and broad, terminated by a large, conical, 3-angled stigma, or style longer, stout, and then terminated by a truncate stigma, the margin ribbed with the impression of the surrounding anthers. Pistillode with rudimentary ovules present or absent. Fruit a 2 or 3(4)valved loculicidal capsule; loculi I- or 2-seeded. Seeds partly or completely surrounded by a free fleshy arillode. Embryo with plano-convex, collateral, fused cotyledons; radicle small, superior, included.

$\mathrm{G}$ e $\mathrm{r} \mathrm{m}$ in a $\mathrm{t}$ i o $\mathrm{n:}$ cryptocotylar, eophylls opposite, simple, toothed ( $A$. polystachya (Wall.) R. N. Parker)

Chromos om e numbers: $n=18,2 n=76$, c. r so.

P oll e n: Pollen grains 4-colporate, subprolate or prolate $(20-35 \mu \mathrm{m}$; amb rounded or quadrangular). Apocolpium large. Ora circular or lalongate. Exine smooth or more frequently scabrous, thickened at the apertures. 
S e c on d a r y x y le m: Vessels: solitary and in radial rows of 2-4(s), rarely with some pore clusters; tangential diameter $60-\mathrm{I} 80 \mu \mathrm{m}$; intervascular pits $(4.5) 6-7.5 \mu \mathrm{m}$; gum present or absent. Ray tissue: heterogeneous Kribs Type 3 or uniseriate-heterogeneous or -homogeneous; rays I- or 2-seriate, up to 35 cells high, the heterocellular with I marginal row. Fibres: septate. Parenchyma. Paratracheal: confluent and banded, often exclusively banded, with or without crystals. Diffuse crystalliferous cells present or absent. Silica deposits were present in the ray tissue of all species examined.

$\mathrm{D}$ i s $\mathrm{t} \mathrm{r}$ i b u $\mathrm{t}$ i o $\mathrm{n}$ : About four species from the Indo-Malayan region to New Guinea and the Solomon Islands.

T y p e s peci es: $A$. grandifolia $\mathrm{Bl}$.

$\mathrm{Rel}$ a t i on $\mathrm{sh}$ i ps: This genus is allied to Aglaia, but is easily distinguished from it by a number of morphological, palynological, and anatomical characters. The embryo of Aphanamixis has cotyledons which are fused throughout their length, a condition unknown elsewhere in the subfamily, except in Sphaerosacme. A differential character never occurring in Aglaia is the simple indumentum, present in all species of Aphanamixis except A. cumingiana (C. DC.) Harms. Other characters found in Aphanamixis but very rarely in Aglaia are the long spicate inflorescence and collateral cotyledons. In the field, the characteristic long, spicate female inflorescence enables Aphanamixis to be identified without difficulty.

The pollen of Aphanamixis differs from that of Aglaia in being consistently 4-colporate, a feature recorded in only one species in Aglaia. In addition, the pollen grains of Aphanamixis are frequently distinctly scabrous while those of Aglaia are always smooth.

In its secondary xylem Aphanamixis is homogeneous and distinct from Aglaia. It differs in the presence of silica deposits in the ray tissue, from Aglaia sensu stricto by the larger intervascular pits $(4.5-7.5 \mu \mathrm{m})$, and from those species of Aglaia formerly included in Amoora by the confluent and banded paratracheal parenchyma, in addition to the usually larger intervascular pits.

Aphanamixis is also fairly close to Lansium and Reinwardtiodendron but may be readily distinguished from them by its corolla of 3 petals ( 5 in Lansium and Reinwardtiodendron), its capsular fruit, and the structure of the seed. The large intervascular pits and presence of silica deposits also distinguish the wood anatomy of Aphanamixis from that of Lansium and Reinwardtiodendron.

In view of the very distinct morphology, palynology, and wood anatomy of this genus, it is surprising that Aphanamixis has so frequently been confused with other members of the Aglaieae.

\section{REINWARDTIODENDRON}

Reinwardtiodendron Koord., Meded. van s'Lands Plantentuin Buitenzorg I9 (I898) 389; Harms in Engl. \& Prantl, Nat. Pflanzenfam., ed. 2, I9 bI (1940) I25. - Fig. Ioc.

Lansium sect. Neolansium Harms in Engl. \& Prantl, Nat. Pflanzenfam., ed, 2, 19 bI (1940) I24. Aglaia sect. Lansium (Corr.) Kosterm., Reinwardtia 7 (I966) 221 pro parte.

Trees with pinnate, trifoliolate, or unifoliolate leaves. Indumentum of simple hairs. Flowers bisexual, in axillary spikes or panicles with spicate branches. Calyx deeply 5lobed; lobes imbricate. Petals 5 , free from each other but fused to the staminal tube at the base. Staminal tube $0.15-0.3 \mathrm{~cm}$ long, globose, cyathiform, or ovoid, with an undulate or toothed margin. Anthers Io, glabrous, in 2 whorls of 5 , the upper partly exserted, the lower alternating with the upper and completely included; anthers of the lower whorl with connective produced to form a short acute appendage. Disk absent. Ovary (3)s-locu- 

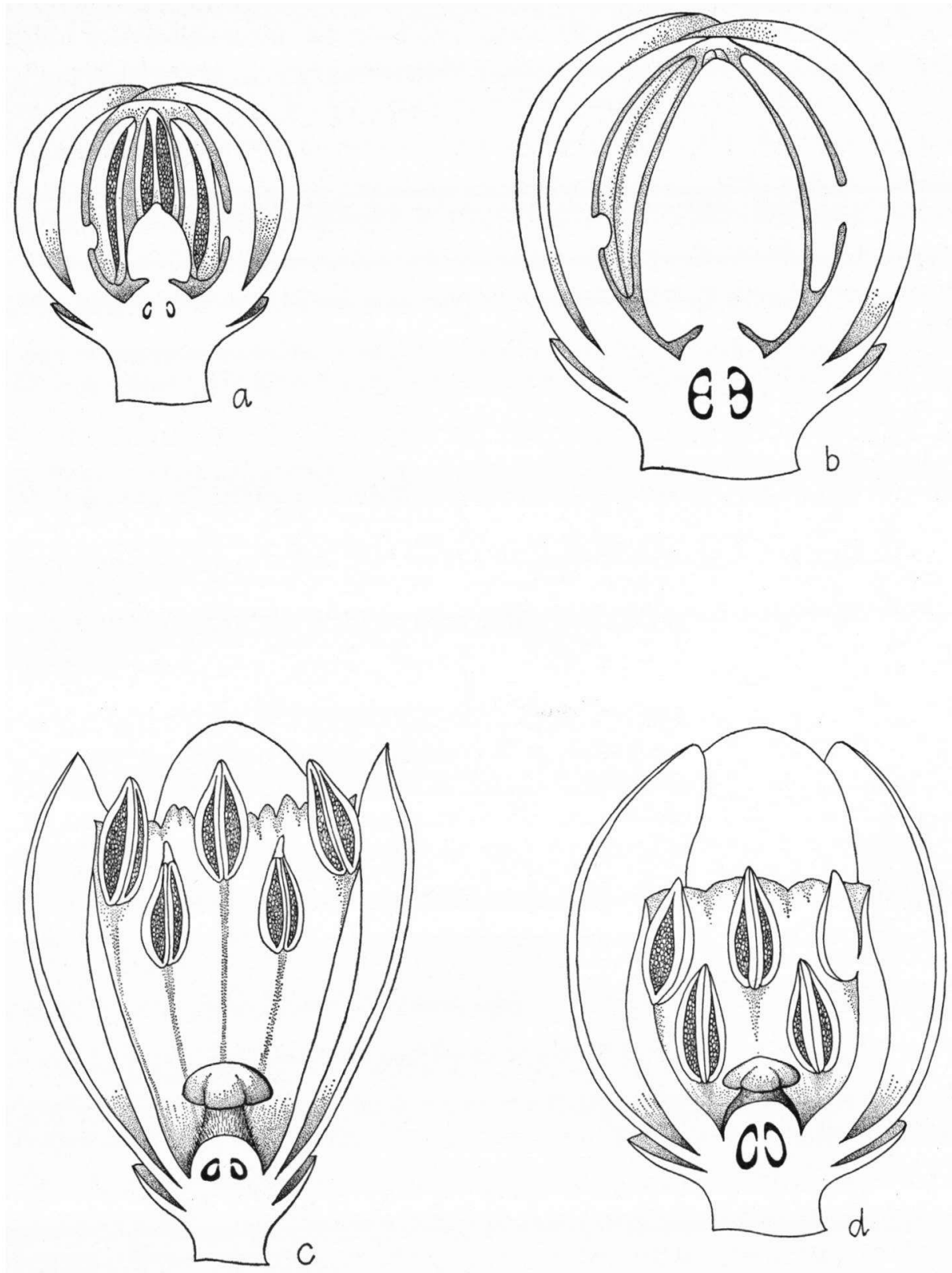

J.Loken

Fig, I0. a. Aphanamixis grandifolia Blume, ${ }^{\star}, \times 8$; b. ditto, $9, \times 8 .-$ c. Reinwardtiodendron sp., d. Sphaerosacme decandra (Wall.) Pennington, $\delta, \times 15$. (a. Pennington 7868 ; b. Pennington 7868 ; c. Pennington 7876; d. Wallich s.n.). 
lar; loculi with I(2) collateral ovules. Style very short, with a small capitate or pileate and obscurely lobed style-head. Fruit a I- or 2 -seeded berry. Seed exarillodiate, usually with a sarcotesta. Embryo with thick, plano-convex, superposed, free cotyledons; radicle included.

P o l l en: Pollen grains 3- or 4-colporate, prolate-spheroidal or subprolate $(22-26 \mu \mathrm{m}$; amb rounded). Apocolpium medium. Ora circular or lalongate. Exine smooth, thickened at the apertures.

S e c ond a r y x y l e m: Vessels: solitary and in radial rows of 2 or 3(5), rarely with some pore clusters; tangential diameter $40-100 \mu \mathrm{m}$; intervascular pits $2.25 \mu \mathrm{m}$; gum present. Ray tissue: homogeneous Kribs Type I or uniseriate-homogeneous; rays I- or 2-seriate, up to 20 cells high. Fibres septate. Parenchyma. Paratracheal: aliform, confluent and banded, with crystals.

$\mathrm{D}$ is $\mathrm{t} \mathrm{r}$ i b u $\mathrm{t}$ i o n: 4 or $\mathrm{s}$ species in the Indo-Malesian region.

Ty p e s pecies: $R$. celebicum Koord.

$\mathrm{R}$ el at i o n s i p s: Reinwardtiodendron is related to Aglaia and Lansium but can be distinguished from both these genera by a number of characters. It differs from all species of Aglaia in its simple indumentum and in its anthers which are arranged in 2 alternating whorls of 5 , the anthers of the lower whorl with the connective produced to form a short acute appendage (anthers of Aglaia in a single whorl without appendages). In addition, the ovary of Reinwardtiodendron is usually s-locular ( $\mathrm{I}-4$-locular in Aglaia). The spicate inflorescence is rarely found in Aglaia.

Reinwardtiodendron is very similar to Aglaia in its pollen morphology and in the structure of its secondary xylem.

It can be distinguished from Lansium by its axillary inflorescence (ramiflorous or cauliflorous in Lansium), the corolla free from the staminal tube almost to the base (fused almost to half way in Lansium), its anthers arranged in 2 whorls of 5, the lower whorl with a connective appendage ( $\mathrm{I}$ whorl of 10 without connective appendages in Lansium).

The pollen grains of Reinwardtiodendron are 3- or 4-colporate, prolate-spheroidal or subprolate, differing from those of Lansium which are 3-s-colporate, oblate-spheroidal.

The secondary xylem of both genera is very similar, but the ray tissue of Lansium (heterogeneous Kribs Type 3) is slightly more heterogeneous than that of Reinwardtiodendron (homogeneous Kribs Type I or uniseriate homogeneous).

N o t e: Lansium humile Hassk. This species, placed by Harms with some reservations in his section Neolansium, cannot be placed with certainty until the nature of the fruit is known. The floral structure is similar in all respects to that of Reinwardtiodendron. Its pollen morphology and the structure of its secondary xylem also agree very closely with that of Reinwardtiodendron. Although Hasskarl described the fruit as a berry, some later authors (e.g. Koorders) have mentioned a loculicidal capsule. Kostermans (I966) has described a large capsular fruit collected by Koorders with 5 large exarillate seeds. Until mature fruit correlated with leaves and flowers is obtained, it is not possible to place this species with certainty, but the floral, pollen, and wood characters alone are sufficient to exclude it from Aglaia, Lansium, Aphanamixis, and Sphaerosacme, but indicate a close relationship with Reinwardtiodendron.

\section{SPHAEROSACME}

Sphaerosacme Wall. [in Roxb., Fl. Ind. (ed. Carey) 2 (1824) 429, in obs., nomen provisorium] ex M. J. Roem., Synops. Monog. Hesperid. I (I846) 98. - Fig. rod.

Lansium sect. Pseudolansium Harms in Engl. \& Prantl, Nat. Pflanzenfam. ed. 2, 19 bI (1940) 125. 
Trees with imparipinnate leaves. Indumentum of simple hairs. Flowers unisexual (plant dioecious). Inflorescence axillary or supra-axillary; male flowers (female flowers not seen by us) in panicles with racemose branches. Calyx deeply 4- or 5-lobed; aestivation open or imbricate. Petals 5, free, imbricate. Staminal tube c. $0.2 \mathrm{~cm}$ long, almost globose, margin undulate. Anthers ro, glabrous, lacking connective appendages, in 2 whorls of 5 , the upper partly exserted, the lower alternating with the upper and completely included. Disk absent. Ovary with 5 uniovulate loculi. Style absent; style-head broad, pileate, 5-lobed. Fruit a 2-5-valved loculicidal capsule. Seed partly or completely surrounded by an arillode. Embryo with plano-convex, collateral, completely fused cotyledons; radicle small, superior, included.

P o 11 e n: Pollen grains 4-colporate, prolate (25-30 $\mu \mathrm{m}$; amb quadrangular). Apocolpium large. Ora lalongate. Exine smooth or scabrous, thickened at the apertures.

Secondary x y lem: not seen.

$\mathrm{D}$ is $\mathrm{t} \mathbf{r} \mathrm{i}$ b u $\mathrm{t}$ i o n: One species in Sikkim, Bhutan, and Nepal.

T y pe s p e ci es: S. decandra (Wall.) Pennington. comb. nov. (Basionym: Aglaia? decandra Wall. in Roxb., Fl. Ind. (ed. Carey) 2 ( 1824 ) 427).

$\mathrm{Re}$ lat i o $\mathrm{sh}$ i ps: The rank and relationships of this plant have been in doubt since it was first described. Wallich tentatively placed it in Aglaia as Aglaia? decandra (I 824). He did not have ripe fruiting material available for study and in his observation after the description states "the fruit is decidedly s-seeded. I have not had the opportunity of examining the latter in the ripe state and have therefore preferred placing the tree here, to forming it into a new genus. Should it prove the latter, the name which I originally gave it, Sphaerosacme, might be adopted." Wight and Arnott (1834) and Hooker $f$. (I862) referred it to Lansium on account of the Io stamens in 2 whorls of 5 , but Hiern (I875), who saw the ripe capsular fruit, placed it in Amoora.

It appears that this genus has almost equal affinities with Reinwardtiodendron and Aphanamixis but is quite distinct from both, and that Roemer (1846) was fully justified in taking up Wallich's provisional name. It possesses the floral characters of Reinwardtiodendron and the fruit and seed characters of Aphanamixis. The following characters separate it from Aphanamixis: petals 5 , free from the staminal tube; anthers 10, in 2 whorls; ovary 5 -locular with a single ovule in each locule.

The differences from Reinwardtiodendron are: petals free from the staminal tube; fruit a loculicidal capsule; seed with a free arillode; cotyledons collateral, fused.

The pollen grains are similar to those of Aphanamixis being 4-colporate with a scabrous exine.

Sphaerosacme is less closely related to Lansium, and differs from it in floral, fruit, and seed characters. It may be distinguished by its petals which are free from the staminal tube (fused in the lower half in Lansium), its anthers in 2 whorls of 5 ( 1 whorl of 10 in Lansium), the fruit which is a loculicidal capsule (berry in Lansium), and its fused collateral cotyledons (free, superposed in Lansium). In addition the prolate pollen grains of Sphaerosacme differ from those of Lansium which are oblate-spheroidal.

\section{Tribe 6. guareeae}

Tribus Guareeae, tribus nova.

Folia pinnat. Tubus stamineus integer, paene semper cylindricus, cum vel sine appendicibus. Antherae paene semper intra fauces insertae. Discus fere evolutus, stipitatus, cyathiformis vel tubularis. Caput styli fere discoideum. Fructus paene semper capsularis, loculicide dehiscens. Semen arillodio vel sarcotesta praeditum, sine endospermio.

Typus tribus: Guarea. 
Leaves pinnate. Indumentum of simple or rarely stellate hairs. Flowers hermaphrodite or unisexual (plants dioecious). Staminal tube complete, nearly always cylindrical, with or without appendages. Anthers nearly always inserted within the throat. Disk usually well-developed, stipitate, cyathiform or tubular. Style-head usually discoid, rarely capitate. Fruit nearly always a loculicidal capsule. Seed arillodiate or with a sarcotesta, exendospermous. Cotyledons plano-convex, collateral or superposed, rarely oblique.

P oll e n: Usually suboblate, oblate-spheroidal, or spheroidal, $3-5$-colporate, exine usually smooth.

Secondar y x y l e m: Fibres nearly always septate; apotracheal terminal bands of parenchyma usually absent; paratracheal parenchyma usually confluent and banded.

I. Disk cyathiform or tubular.

2. Leaflets with pellucid lines and dots; calyx lobed, with imbricate aestivation; petals imbricate, free from the staminal tube; seed arillodiate. . . . . 26. Cabralea

2a. Leaflets without pellucid lines or dots; calyx entire or lobed, aestivation open or imbricate; petals imbricate or valvate, free from, or fused to, the staminal tube; seed arillodiate or with a sarcotesta ......... 35. Dysoxylum

Ia. Disk annular or stipitate, rarely patelliform or absent.

3. Sarcotesta surrounding the base of the seed, greatly swollen; disk short, stipitate; fruit a capsule; cotyledons collateral . . . . . . . . 27. Ruagea

3a. Sarcotesta absent or, when present, not swollen or basal.

4. Ovary unilocular with 2(3) parietal placentas; disk long, slender, stipitate, expanded at the apex; fruit a narrow rostrate berry; seed with a vascularised sarcotesta; cotyledons collateral . . . . . . . 25. Heckeldora

4a. Ovary bi- or multi-locular, with axile placentas; fruit a capsule.

5. The two seeds of a locule united by a common arillode; petals imbricate, free; staminal tube cyathiform; disk a swollen annulus; cotyledons collateral ................... 32. Synoum

sa. Seeds not united by a common arillode.

6. Petals fused to the staminal tube for the greater part of its length, valvate; staminal tube long cylindrical; disk absent; seed with a nonvascularised sarcotesta; cotyledons superposed . 28. Turraeanthus

6a. Petals free from or rarely fused at the base to the staminal tube; disk mostly present.

7. Leaves paripinnate.

8. Petals 3 or 4 , valvate at least in the lower half; staminal tube cylindrical; loculi with 2 collateral ovules; seed with an arillode . . . . . . . . 34. Pseudocarapa

8a. Petals 5, imbricate; staminal tube cyathiform; loculi uniovulate; fruit a capsule; seed with a non-vascularised sarcotesta

33. Anthocarapa

7a. Leaves with a dormant terminal bud or more rarely a terminal leaflet.

9. Petals in 2 whorls, united below; seed with a sarcotesta

9a. Petals in a single whorl.

31. Megaphyllaea

I0. Anthers nearly always locellate; style-head often capitate; seed often scutiform (ovules orthotropous), arillodiate or with a sarcotesta, the latter often mealy white

30. Chisocheton 
roa. Anthers never locellate; style-head always discoid; seed never scutiform, exarillodiate, with a fleshy, mealy, or vascularised sarcotesta . . . . . 29. Guarea

\section{HECKELDORA}

Heckeldora Pierre, Bull. Soc. Linn. Paris 2 (1897) 1286. - Fig. Ir a.

Guarea sect. Heckeldora (Pierre) Harms in Engl. \& Prantl, Nat. Pflanzenfam., ed. 2, 19 bI (1940) I35.

Small trees or treelets with imparipinnate leaves. Indumentum of simple hairs. Leaflets without pellucid lines or dots. Flowers unisexual (plants dioecious) in narrow axillary panicles or racemes. Calyx shallowly 3-5-lobed. Petals 4, free, imbricate. Staminal tube $0.65-0.9 \mathrm{~cm}$ long, cylindrical, the margin with shallow, rounded lobes. Anthers 8 , glabrous, inserted within the throat of the staminal tube and sometimes partly exserted. Disk long, slender, stipitate, expanded at the apex to form a collar beneath the constricted base of the ovary. Ovary unilocular with $2(3)$ parietal placentas, each with 2 collateral ovules. Style-head discoid, flat or with a slight central depression. Fruit a narrow, rostrate, 2-4-seeded berry, with conspicuous constrictions between the seeds. Seed with a vascularised sarcotesta. Embryo with thick, plano-convex, collateral cotyledons; radicle superior, extending to the surface.

Poll e n: Pollen grains 3 or $4(5)$-colporate, oblate-spheroidal $(40-45 \mu \mathrm{m}$; amb rounded). A pocolpium large. Ora circular, crassimarginate. Exine scabrous to verrucose.

$\mathrm{D}$ is $\mathbf{t} \mathbf{r}$ i b u t i o n: One very variable species in tropical West Africa.

T y pes pecie s: $H$. latifolia Pierre (here chosen as lectotype); equals $H$. staudtii (Harms) Staner (Guarea staudtii Harms).

Relationships: Harms treated this genus as a section of Guarea, which is surprising as it differs significantly from that genus in several respects. The unilocular ovary with parietal placentas is a condition unique in the family. Other differences from Guarea are the berry and the embryo with collateral cotyledons and superior radicle, though the latter does occur rarely in Guarea.

The pollen grains of Heckeldora also show several differences from those of all species of Guarea examined so far. The pores protrude (crassimarginate) and the exine is prominently scabrous or verrucose, whereas in Guarea the pores do not protrude and the exine is smooth and rarely scabrous.

\section{CABRALEA}

CabraleaA. Juss., Mém. Mus. Hist. Nat. Par. I9 (?1830) 229, t. I6; Harms in Engl. \& Prantl,Nat. Pflanzenfam., ed. 2, 19 bI (1940) I58, t. 35 figs R, S. - Fig. Irb.

Trees or shrubs. Indumentum of simple hairs. Leaves pinnate with limited apical growth; leaflets with pellucid lines and dots. Flowers unisexual (plants dioecious), in axillary panicles. Calyx deeply s-lobed, lobes imbricate. Petals 5 , free, imbricate. Staminal tube $0.3-0.5 \mathrm{~cm}$ long, cylindrical, terminated by $9-12$ short truncate, emarginate, or bilobed appendages. Anthers glabrous, alternate with the appendages, inserted within the throat of the staminal tube and completely included. Disk cyathiform. Ovary 4 or s-locular; loculi with 2 superposed ovules, placentation axile. Style-head discoid, with a small central depression. Fruit a tardily dehiscent 4 - or 5 -valved loculicidal capsule, pericarp rather fleshy; loculi I- or 2-seeded. Seed partly or completely surrounded by a thin arillode. Embryo with thick collateral cotyledons; radicle superior, slightly projecting or extending to the surface. 
P oll e n: Pollen grains (3) 4(s)-colporate, spheroidal or prolate-spheroidal (35-5o $\mu \mathrm{m}$; amb rounded or quadrangular, rarely triangular). Apocolpium large or rarely medium. Ora circular. Exine smooth or rarely scabrous.

S e c o n d a r y $x$ y l e m: Vessels solitary and in radial groups of 2 or 3; tangential diameter 80-160 $\mu \mathrm{m}$; intervascular pits $4.5 \mu \mathrm{m}$; gum present. Ray tissue heterogeneous Kribs Type 2 or 3 or uniseriate heterogeneous; rays I- or 2-seriate, up to 30 cells high, the heterocellular with I or 2 marginal rows. Fibres: septate. Parenchyma. Paratracheal: vasicentric, aliform, confluent and sometimes banded, in various combinations; crystals present or absent.

$\mathrm{D}$ is $\mathrm{t} \mathrm{r}$ i b u $\mathrm{t}$ i o $\mathrm{n}$ : About 6 species in southern Brazil and neighbouring countries in S. America.

Ty pe species: $C$. polytricha A. Juss.

Relationsh ips: Harms, on the basis of morphological information alone, considered Cabralea to be most closely related to the Asiatic genus Didymocheton (included under Dysoxylum in the present work) on account of the free cyathiform disk surrounding the ovary, a structure to which he attached great importance. It also shares many features with the South American genus Ruagea, and the secondary xylem of the latter has a combination of characters very close to that of Cabralea.

Cabralea differs from Didymocheton in the following characters: leaves with pellucid lines or dots; in Cabralea the petals are always free whereas in Didymocheton they are generally fused to the staminal tube.

The leaves with pellucid lines and dots also distinguish Cabralea from Ruagea. Cabralea also has a cyathiform disk (not stipitate); 4- or s-locular ovary (not 3 or 4-locular); an arillodiate seed (not a basal swollen sarcotesta).

The secondary xylem of Cabralea more closely resembles that of Ruagea than that of Didymocheton. It lacks the exclusively banded paratracheal parenchyma of Didymocheton. The following combination of characters - thin-walled fibres, small number of vessels per sq $\mathrm{mm}(8-\mathrm{I} 2)$, and sparse parenchyma - is characteristic of Ruagea.

\section{RUAGEA}

Ruagea Karsten, Fl. Columb. 2 (1863) 51, t. 126; Harms in Engl. \& Prantl, Nat. Pflanzenfam., ed. 2, 19 bI (1940) 137, t. 31 fig. Z. - Fig. IIC.

Guarea sect. Ruagea C. DC. in A. \& C. DC., Monog. Phan. I (1878) 577.

Trees with imparipinnate leaves. Indumentum of simple hairs. Leaflets sometimes with pellucid lines or dots. Flowers ?bisexual, in axillary panicles or occasionally ramiflorous. Caly $x$ deeply s-lobed, lobes imbricate. Petals s, free, imbricate. Staminal tube $0.175-0.9 \mathrm{~cm}$ long, cylindrical, margin undulate, crenate, or with shallow emarginate lobes. Anthers 9 or Io, glabrous, inserted within the throat of the staminal tube, included or partly exserted. Disk short, broad, stipitate, sometimes expanded to form a collar at the base of the ovary. Ovary 3(4)-locular; loculi with 2 superposed ovules, placentation axile. Stylehead discoid with a small central depression. Fruit a I-3-valved loculicidal capsule, loculi I(2)-seeded; pericarp thin and leathery or rather woody. Seed with a large, swollen, fleshy, basal sarcotesta. Embryo with thick, plano-convex, collateral cotyledons; radicle superior, included or extending to the surface.

P olle n: Pollen grains 4-colporate, suboblate, oblate-spheroidal, spheroidal, or prolate-spheroidal (45- $55 \mu \mathrm{m}$; amb rounded). Apocolpium large or medium. Ora circular or lalongate. Exine smooth, thickened at the apertures.

Secondary x y le m: Vessels solitary and in radial pairs; tangential diameter 

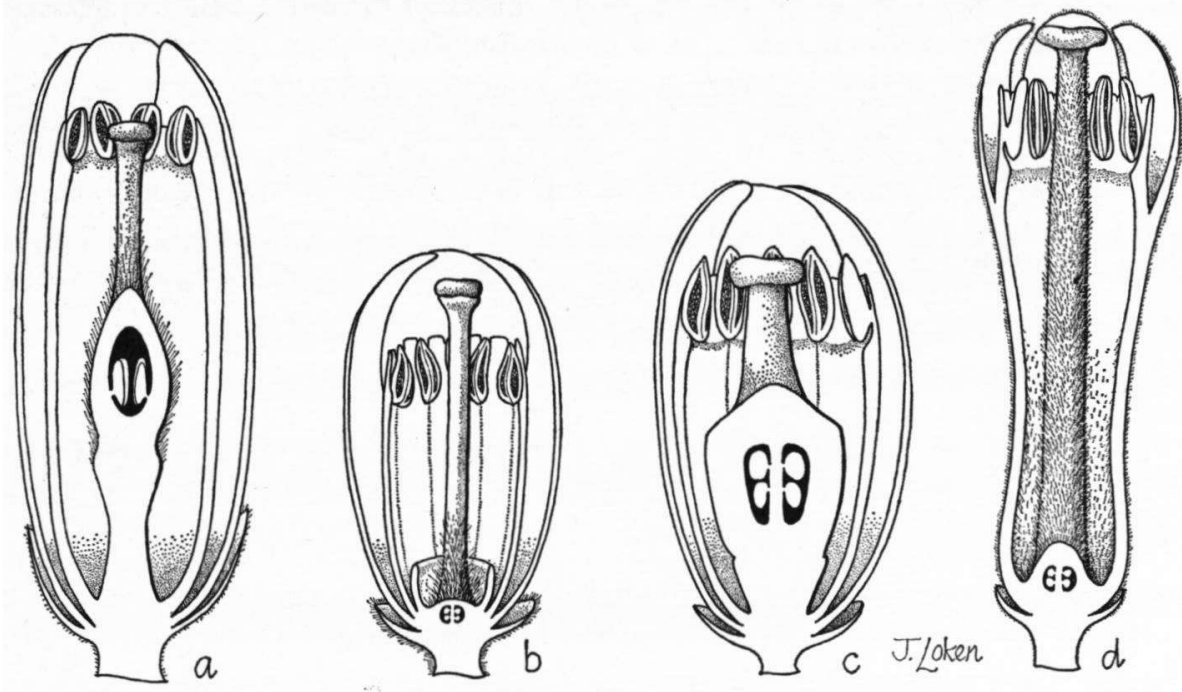

Fig. II. 2. Heckeldora staudtii (Harms) Staner, đ, ×7.5. - b. Cabralea polytricha A. Juss., đ, X7.5. - c. Ruagea pubescens Karst., \&, $\times$ 7.5. - d. Tumaeanthus zenkeri Harms, סै. X5. (2. FHI 30772; b. Glaziou 20815; c. Steyermark 55048; d. Zenker 2155).

80-120 $\mu \mathrm{m}$; intervascular pits $4.5 \mu \mathrm{m}$; gum present. Ray tissue heterogeneous Kribs Type 3; rays I- or 2-seriate, up to so cells high, the heterocellular with I marginal row; some rays homocellluar with all cells procumbent. Fibres septate. Parenchyma. Paratracheal: aliform and confluent.

D is t $\mathrm{r}$ i b u $\mathrm{t}$ i o $\mathrm{n}$ : One species in Costa Rica, C. America, and about five in western South America from Bolivia and Peru to Venezuela.

T y p e species: $R$. pubescens Karst.

Rel a ti o n s i ps: Ruagea is separable from Guarea by two diagnostic characters. These are the imbricate (not open) calyx-lobes and the peculiar, greatly swollen, basal sarcotesta which is quite unlike that of Guarea or Chisocheton.

Other characters constant in Ruagea but occurring only sporadically in Guarea are the $S$-merous flowers and the embryo with collateral cotyledons and superior radicle.

Only one slide of the secondary xylem of Ruagea has been examined ( $R$. silviandina Cuatrec.). This shows the main features of Guarea, but the paratracheal parenchyma is rather sparse and only aliform or confluent. This feature, combined with the rather thinwalled fibres, produces an overall pattern which could not be confused with that of Guarea.

\section{TURRAEANTHUS}

Turraeanthus Baill. [Adansonia 11 (1874) 261 sine descr. gen.] Hist. PL. 5 (1874/s) s00; Harms in Engl. \& Prantl, Nat. Pflanzenfam., ed. 2, I9 bI (1940) 147, t. 30 figs. A-D; t. 32. - Fig. IId. [ Turraeopsis Baill., Hist. P1. 5 (1874/5) 483, nom. nud.]

Bingeria A. Chev., Veg. Util. Afr. Trop. Franç. s (1909) t89.

Trees or treelets with pinnate leaves. Indumentum of simple hairs. Leaflets without pellucid lines or dots. Flowers unisexual (plants dioecious), in axillary panicles or ramiflorous. Calyx almost entire or shallowly and irregularly lobed. Petals 4 or s(6), valvate, 
fused in the upper half to the staminal tube. Staminal tube $\mathrm{I}-3 \mathrm{~cm}$ long, cylindrical, slightly expanded at the mouth, margin crenate or shallowly lobed. Anthers 8-r2, glabrous, in a single irregular whorl inserted within the throat of the staminal tube, completely included or partly exserted. Disk absent. Ovary 4- or 5-locular; loculi with 2 superposed or oblique ovules, placentation axile. Style-head discoid with a slight central depression. Fruit a somewhat fleshy, 3-5-valved, loculicidal capsule, the loculi I-seeded. Seed with a fleshy non-vascularized sarcotesta. Embryo with thick, plano-convex, superposed cotyledons; radicle included, usually near the abaxial surface.

Germination: cryptocotylar; cataphylls present; eophylls spirally arranged, simple, entire ( $T$. africanus (Welw. ex C. DC.) Pellegr.).

Ch rom os o m e n u m b e r: $2 n=c .280$ (T. africanus (Welw.ex. C. DC.) Pellegr.).

P oll e n: Pollen grains 4- or 5-colporate, suboblate, oblate-spheroidal, or spheroidal ( $55-65 \mu \mathrm{m}$; amb rounded). A pocolpium large. Ora lalongate, sometimes crassimarginate. Exine smooth, thickened at the apertures.

$\mathrm{Sec}$ ond a r y $x$ y l e m: Vessels solitary and in radial groups of 2 or 3; rangential diameter 80- $140 \mu \mathrm{m}$; intervascular pits $3.75 \mu \mathrm{m}$; gum present or absent. Ray tissue heterogeneous Kribs Type 3; rays (I)2(3)-seriate, up to 20 cells high, the heterocellular with I marginal row. Fibres non-septate. Parenchyma. Paratracheal: vasicentric, crystals present.

$\mathrm{D}$ i s $\mathrm{t} \mathbf{r}$ i b u t $\mathrm{i}$ o $\mathrm{n}$ : Possibly three species in tropical West Africa.

T y p e s p e ci es: $T$. longipes Baill. (here chosen as lectotype).

$\mathrm{Re}$ lat i onsh i ps: Turraeanthus is closely related to both Chisocheton and Guarea. It differs from both in having the corolla fused for the greater part of its length to the staminal tube. Further differences are the lack of the dormant terminal bud on the leaf present in most species of both genera, of the locellate anthers present in most species of Chisocheton, and of the stipitate disk characterizing most species of Guarea.

In its secondary xylem, Turraeanthus is quite distinct from both Guarea and Chisocheton in having non-septate fibres and very sparse vasicentric paratracheal parenchyma (not confluent or banded). The deposits of silica so characteristic of Chisocheton and occasionally found in Guarea are absent from the ray tissue of Turraeanthus.

\section{GUAREA}

Guarea ('Guara') Allamand ex L., Mant. (177I) I 50, 228, nom. cons.; Harms in Engl. \& Prantl, Nat. Pflanzenfam., ed. 2, I9 bI (1940) I29, t. 31, figs. R-X. - Fig. I2a, b.

Samyda L., Sp. Pl. (I753) 443, nom. rejic., non Jacq. (1760) nom. cons.

Guidonia Mill., Gard. Dict. abridg. ed. 4 (1754).

Elutheria P. Browne, Hist. Jamaica (1756) 369 , non Elutheria M. J. Roem. (1846)=Schmardaea Karst. (1861).

Plumea Lunan., Hort. Jam. 2(2) (1814) 77.

Sycocarpus Britton, Bull. Torrey Bot. Club 14 (1887) 143.

Leplaea Vermoesen, Revue Zoolog. Afric. 9(2) (r921) 37; Harms in Engl. \& Prantl., ed. 2, I9 bI (1940) I37.

Urbanoguarea Harms, Notizbl. Bot. Gart. Berl. 13 (1937) 507 in obs. 10; in Engl. \& Prantl, Nat. Pflanzenfam., ed. 2 , 19 bI (1940) 136.

Trees or treelets. Indumentum of simple hairs. Leaves pinnate, with a dormant terminal bud or more rarely a terminal leaflet. Leaflets sometimes with pellucid lines or dots. Inflorescence axillary or ramiflorous or cauliflorous, usually racemose or spicate, more rarely paniculate. Flowers unisexual (plants dioecious). Calyx with an almost entire margin, or shallowly or deeply (2) 3- or $4(6)$-lobed, aestivation open; rarely closed in bud and circumscissile at the base. Petals $4(6)$ in a single whorl, free, imbricate or valvate, rarely fused at the base to the staminal tube. Staminal tube $0.4-1.3 \mathrm{~cm}$ long, cylindrical, the margin shallowly 
toothed, crenate, or entire, or with emarginate or truncate appendages. Anthers 8(-12), glabrous, inserted within the throat of the staminal tube, completely included or partly exserted, alternate with the lobes or appendages. Antherodes similar, smaller, without pollen. Disk short- or long-stipitate, sometimes expanded to form a collar at the base of the ovary, rarely absent. Ovary (2) $4-6$ (Io)-locular; loculi with 1 or 2 superposed ovules, placentation axile. Style-head discoid, usually with a small central depression. Pistillode smaller, less swollen, with well-developed ovules. Fruit a 2-8-valved loculicidal capsule, sometimes very slow to dehisce; loculi I- or 2-seeded; pericarp leathery or woody with the endocarp sometimes distinguished as a cartilaginous layer. Seed often shaped like the segment of an orange, with a fleshy, sometimes vascularised, or mealy sarcotesta, usually thickened on the adaxial surface. Embryo with thick, plano-convex, superposed or more rarely oblique or collateral cotyledons; radicle abaxial, extending to the surface, or rarely central or lateral and then included.

G e r m i n a t i o n: cryptocotylar, cophylls opposite or spirally arranged, trifoliolate, sometimes becoming simple (G. cedrata (A. Chev.) Pellegr., G. mayombensis Pellegr.).

Chromosome n u m bers: $2 n=72$ (3 spp.).

P oll e n: Pollen grains 3-5-colporate, oblate-spheroidal or spheroidal (30-50 $\mu \mathrm{m}$; amb rounded). Apocolpium large. Ora circular or rarely lalongate. Exine smooth or rarely scabrous, thickened at the apertures.

S e c o n d a r y $x$ y le m: Vessels solitary and in radial rows of 2 or 3 (4); tangential diameter $40-240 \mu \mathrm{m}$; intervascular pits $2.25-5.25 \mu \mathrm{m}$; gum present or absent. Ray tissue usually homogeneous Kribs Type I, rarely heterogeneous Kribs Type 3, or uniseriate-homogeneous; rays I or $2(4)$-seriate, up to so cells high, the heterocellular with I marginal row. Fibres septate. Parenchyma. Paratracheal: confluent and banded, rarely with some aliform as well; with crystals. Diffuse crystalliferous cells very rarely present. Deposits of silica are occasionally present.

$\mathrm{D}$ is $\mathrm{t} \mathrm{r}$ i b u $\mathrm{t}$ i o $\mathrm{n}$ : Five species in tropical Africa and perhaps 30 in tropical America.

T y pe s peci es: G. trichilioides L. = G. guidonia (L.) Sleumer.

Rel a ti on sh i ps: On the basis of this study, we have not been able to agree with Harms' circumscription of Guarea, in that he includes one genus that clearly does not belong here, and gives generic rank to two others which in our opinion are congeneric.

The reasons for excluding Heckeldora from Guarea are given in the commentary following the account of the former genus.

Harms maintains the genus Urbanoguarea, based on Guarea sphenophylla Urban from Santo Domingo, on account of the distinctive form of the calyx and leaflets. We have not had an opportunity of studying flowering material of this species, but the original description of Urban fits that of Guarea. The calyx is deeply divided, but this feature is known elsewhere in Guarea, and it appears that the leathery texture of the calyx lobes and leaves is merely an adaptation to a dry habitat. A comparable condition is found in the section Acanthotrichilia Urban of Trichilia from the same country. Harms also states that the juvenile form has deeply divided leaflets, a condition known to occur sporadically in several other genera, e.g. Dysoxylum. On the basis of the available evidence, Urbanoguarea does not merit generic rank.

Harms (1940) gives Leplaea generic rank on account of the indehiscent fruit. We have examined mature fruit preserved in spirit. These have not dehisced but the inner surface of the pericarp is split along the centre of each loculus and it is clear that this fruit would dehisce into four valves on falling to the ground, if not before. Uncorrelated, dehisced, fallen fruits have been reported by field workers (Hallé, in Herb. Paris). It is often difficult to decide from dried herbarium material whether the fruit of several species of Guarea 


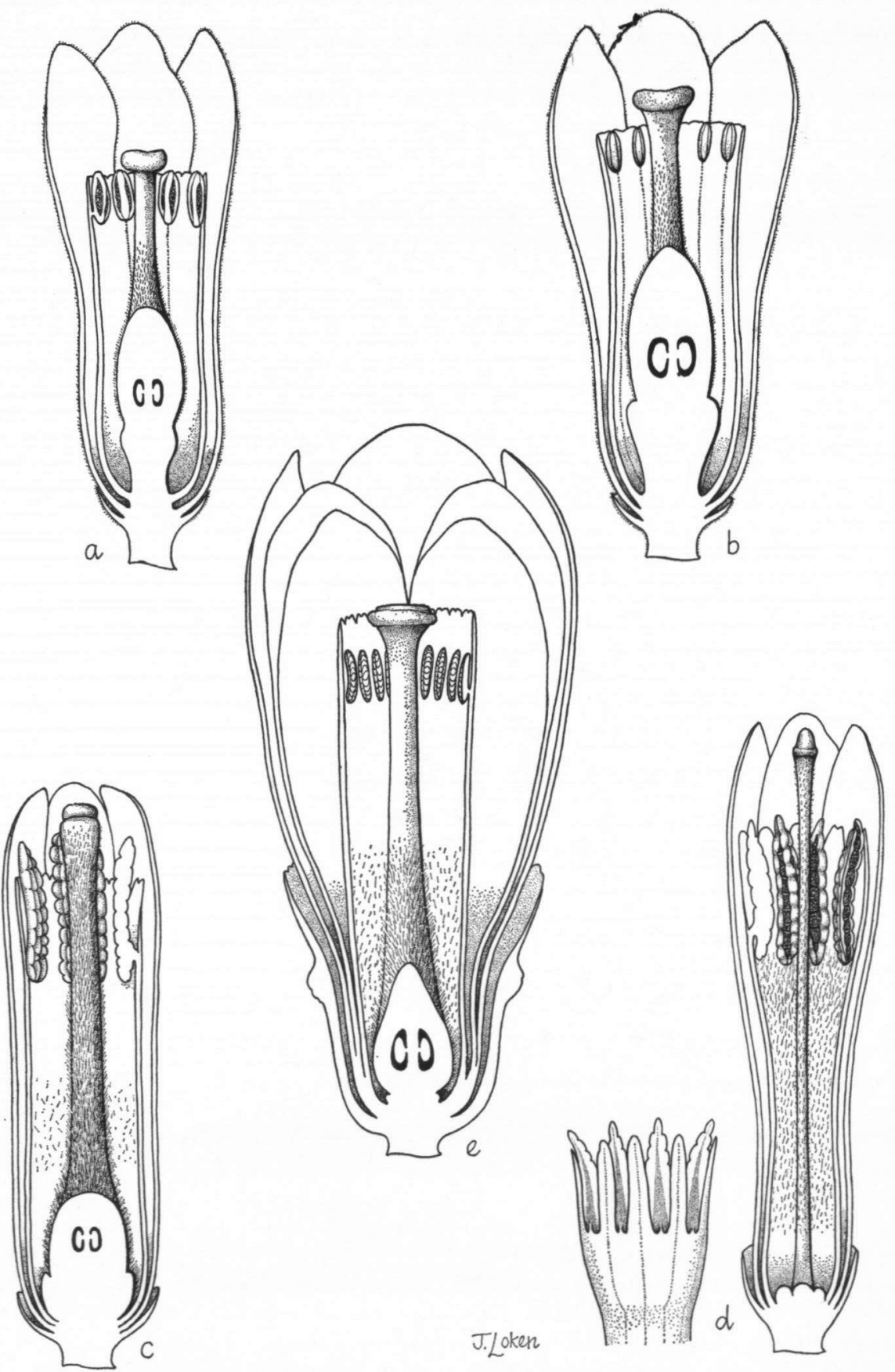

Fig. 12. 2. Guarea guidonia (L.) Sleumer, $\delta, \times 10 ;$ b. ditto, $ᄋ, \times$ ro. $-c$. Chisocheton divergens Blume,, ,

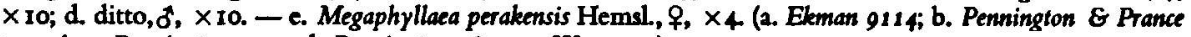
1337A; c. Pennington 7995; d. Pennington 7830; c. Wray s.n.). 
is dehiscent, and field observation of the related genus Chisocheton shows that, although there may be no sutures evident on the mature fruit, dehiscence may take place, though sometimes after the fruit has fallen As Leplaea resembles Guarea in all other characters of gross morphology, wood anatomy, and pollen grain structure, it seems better to reduce it to this genus. Indeed in its vegetative features $L$. mayombensis (Pellegr.) Staner much more closely resembles the African species Guarea cedrata (A. Chev.) Pellegr. than the latter resembles the only other tree species in Africa, G. thompsonii Sprague \& Hutch. Sterile and flowering specimens of Leplaea and $G$. cedrata have been confused by herbarium taxonomists.

The relationships of Guarea with Ruagea, Heckeldora, Turraeanthus, Chisocheton, Pseudocarapa, Anthocarapa, Synoum, and Dysoxylum are discussed under the respective genera.

\section{CHISOCHETON}

Chisocheton Blume, Bijdr. (1825) 168; Harms in Engl. \& Prantl, Nat. Pflanzenfam. ed. 2, 19 bI (1940) I so, t. 30 figs. E-H, t. 33. - Fig. 12c, d.

Schizochiton Spreng., Syst. 4(2) cur. post. (1827) 251 .

Dasycoleum Turcz., Bull. Soc. Nat. Mosc. 3I(I) (1858) 414.

Melio-Schinzia K. Schum. in Schum. \& Hollrung., Fl. Kaiser Wilh. Land. (1889) 62.

Rhetinosperma Radlk in Engl. \& Prantl, Nat. Pflanzenfam. Nachtrag 3, Ergänzungsheft 2(3) (1907) 204; Harms, tom. cit. 166.

Clemensia Merrill, Philipp. Journ. Sci. 3 (1908) 143; Harms, tom. cit. 155, tab. 34, non Schlecht. (1915),

Trees or treelets. Indumentum usually of simple, rarely of stellate hairs. Leaves pinnate with an intermittently growing terminal bud, very rarely with a terminal leaflet. Leaflets without pellucid lines or dots. Flowers unisexual (plants dioecious), in axillary or supraaxillary panicles, often long and narrow and thyrsoid or almost racemose, rarely cauliflorous, very rarely epiphyllous. Calyx usually with an almost entire margin, rarely 3-6-lobed to the middle, sometimes closed in bud and splitting to produce an irregular margin, and then circumscissile at the base. Petals (3) 4 or s(I4) in a single whorl, free, imbricate or valvate, rarely united below or fused at the base to the staminal tube. Staminal tube $0.6-3 \mathrm{~cm}$ long, cylindrical, sometimes expanded at the mouth, with an entire or crenate margin, or terminated by 4- $\mathrm{IO}(23)$ emarginate, truncate, narrowly lanceolate, or bilobed appendages. Anthers hairy or glabrous, nearly always locellate, alternate with the lobes or appendages, usually attached within the throat of the staminal tube and then completely included or partly exserted, rarely inserted on the margin. Antherodes very slender, indehiscent, without pollen. Disk narrowly or broadly stipitate, annular, patelliform, or absent. Ovary 2-7-locular; loculi with I or 2 collateral or superposed ovules, placentation axile. Style-head small, capitate, clavate, or discoid. Pistillode very slender, the unexpanded base of the style sunk in the disk; ovules minute or absent. Fruit a 2-s(7)valved loculicidal capsule, often stipitate or rostrate, the loculi I(2)-seeded; pericarp usually leathery, or almost woody throughout, occasionally with a soft spongy mesocarp. Seed scutiform or shaped like the segment of an orange, arillodiate or with a sarcotesta; arillode adaxial or partly surrounding the seed, partly fused to the testa or free; sarcotesta partly or completely thickened and fleshy; hilum often very large, mealy white and strongly vascularised, covering up to $\frac{1}{2}$ or $\frac{1}{2}$ of the seed. Embryo with thick, collateral, oblique or superposed cotyledons; radicle abaxial or included.

G e r m in a $t$ i o n: cryptocotylar; eophylls spirally arranged, simple, entire.

Chrom os om e n m bers: $n=23,2 n=46,92$.

P oll e n: Pollen grains 3-s-colporate, oblate-spheroidal or spheroidal (3s-10s $\mu \mathrm{m}$; 
amb rounded). Apocolpium large. Ora circular or lalongate, sometimes crassimarginate. Exine smooth or scabrous, thickened at the apertures.

$S$ e c on d a r y $x$ y $1 \mathrm{em}$ : Vessels solitary and in radial rows of $2-4(5)$; tangential diameter $60-\mathrm{r} 80 \mu \mathrm{m}$; intervascular pits $3.5-6 \mu \mathrm{m}$; gum present or absent. Ray tissue heterogeneous Kribs Type 3, rarely Kribs Type 2; rays $I-3(5)$-seriate, up to 60 cells high, the heterocellular with I or rarely several marginal rows. Fibres septate. Parenchyma. Paratracheal: exclusively banded or rarely confluent and banded, crystals usually present. Deposits of silica, often abundant, are found in the great majority of species.

$\mathrm{D}$ is tribution: About 30 species from the Indo-Malayan region to Australia, New Guinea, and the Solomon Islands.

$\mathrm{T}$ y p e s p e c i es: $C$. divergens $\mathrm{Bl}$.

$\mathrm{R}$ elations hips: The only differences which separate Clemensia from Chisocheton sensu stricto are quantitative. The flowers are larger, with more petals (7-I4 compared with $4-6$ ), with more anthers ( $15-23$ compared with 4-15), and the ovary with more loculi (6 or 7 compared with 2-6). In all other important respects, Clemensia does not differ from Chisocheton. In 1937 Airy-Shaw demoted Clemensia to sectional rank within Chisocheton, but Harms (1940) retained it as a genus. In our opinion there can be no doubt that Airy-Shaw's view is the more acceptable. The pollen grains of Clemensia are larger than those of Chisocheton sensu stricto (100-I05 $\mu \mathrm{m}$ compared with $40-80 \mu \mathrm{m}$ ), but are otherwise similar. The secondary xylem shows no difference. Both species of Clemensia were described as having indehiscent fruit, but our own field observation has shown that the fruits of Chisocheton medusae Airy-Shaw are tardily dehiscent.

There are no absolutely diagnostic characters that can be used to distinguish Chisocheton from Guarea, but nevertheless all species of Chisocheton differ from Guarea at least in two or three differential characters, so that, although the genera are indeed closely related, no practical difficulties arise in their separation.

All except two species of Chisocheton studied by us have locellate anthers, a character not seen in any other genus except Megaphyllaea. Chisocheton frequently has a capitate style-head and arillodiate seed, whereas in Guarea the style-head is always discoid and the seed always has a sarcotesta. Generally the staminal tube of Chisocheton is longer and narrower - ratio of length to breadth (2.I)6(21.5) - than that of Guarea - ratio (I.4)2 (3.75).

The secondary xylem of these two genera also shows great similarity. They are alike in most features, but Chisocheton generally has more heterogeneous ray tissue and exclusively banded paratracheal parenchyma, whereas in Guarea there is a mixture of confluent and banded parenchyma. Silica deposits occur in both genera, but much more frequently in Chisocheton.

The relationships of Chisocheton with Megaphyllaea and Dysoxylum are discussed under the respective genera.

\section{MEGAPHYLLAEA}

Megaphyllaea Hemsl. in Hook. Ic. Pl. (I887) 18 t. 1708; Harms in Engl. \& Prantl, Nat. Pflanzenfam., ed. 2, 19 bI (1940) I55. - Fig. I2e.

Small trees. Indumentum of simple hairs. Leaves pinnate, with a dormant terminal bud. Leaflets without pellucid lines or dots. Flowers (male not seen) unisexual (plants dioecious) in lax axillary or supra-axillary panicles. Calyx much thickened in the lower half and with a warty swollen band round the middle; closed in bud and splitting to produce an irregular margin and then circumscissile at the base. Petals 8-10, in 2 whorls united below 
and fused at the base to the staminal tube, imbricate. Staminal tube c. I.2 cm long, cylindrical, with an almost entire, crenate, or shallowly toothed margin. Antherodes 10-16, glabrous, locellate, inserted within the throat of the staminal tube, completely included, slender, not dehiscing, without pollen. Disk short, broad, stipitate, obscurely lobed. Ovary 7-9-locular; loculi uniovulate, placentation axile. Style-head discoid. Fruit (immature studied only) a 7-9-valved loculicidal capsule with a thick leathery pericarp. Seed with a fleshy sarcotesta. Embryo with thick superposed cotyledons; radicle included.

P o ll e n: Not seen.

Secondar y x y l e m: Vessels solitary and in radial groups of 2 or 3, tangential diameter $\mathrm{I}_{40}-320 \mu \mathrm{m}$; intervascular pits $6 \mu \mathrm{m}$; gum present. Ray tissue: homogeneous Kribs Type I; rays 2- or 3-seriate, up to Ioo cells high. Fibres: septate. Parenchyma. Paratracheal: banded; crystals present.

$\mathrm{D}$ is t r i b u t i o n: One or two species in the Malay Peninsula.

T y p e s p e ci es: $M$. perakensis Hemsl.

$\mathrm{R}$ el a $\mathrm{t}$ i o $\mathrm{n} \mathrm{sh}$ i ps: This genus can be distinguished from Chisocheton by its biseriate corolla. Other characters rarely found in Chisocheton are the much thickened calyx and the multilocular ovary (the latter only in section Clemensia of Chisocheton).

We have seen only one (uncorrelated) slide of the secondary xylem of Megaphyllaea which is similar to that of Chisocheton but has homogeneous ray tissue (Kribs Type I) and slightly broader bands of paratracheal parenchyma (7-i I cells wide compared with 6-8 in C. macrophyllus King). Silica deposits, present in the majority of species of Chisocheton, are absent.

\section{SYNOUM}

Synoum A. Juss., Mém. Mus. Hist. Nat. Par. I9 (?I830) 226, t. Is; Harms in Engl. \& Prantl, Nat. Pflanzenfam. ed. 2, 19 bI (1940) 138. t. 30 figs. R, S. - Fig. 13a.

Small trees with imparipinnate leaves. Indumentum of simple hairs. Leaflets without pellucid lines or dots. Flowers probably unisexual (plants dioecious), in short axillary panicles. Calyx deeply 4(s)-lobed. Petals $4(5)$, free, imbricate. Staminal tube c. $0.35 \mathrm{~cm}$ long, cyathiform, the margin irregularly and shallowly lobed. Anthers 8(Io), glabrous, inserted just inside the throat of the staminal tube and partly exserted. Disk represented by the swollen basal portion of the ovary. Ovary 2- or 3-locular; loculi with 2 collatera] ovules, placentation axile. Style-head discoid, with a slight depression in the centre. Fruit a 2- or 3-valved loculicidal capsule, the loculi (I)2-seeded; the 2 collateral seeds partly surrounded by a common thick and fleshy arillode which is fused to each seed along the abaxial surface, but is otherwise free. Embryo with thick plano-convex, collateral cotyledons; radicle superior, extending to the surface.

Germin a t i on: phanerocotylar; eophylls spirally arranged, simple, entire or remotely toothed.

Ch rom os om e $\mathrm{n} \mathrm{u} \mathrm{m} \mathrm{ber:} 2 \mathrm{n}=84$ (S. glandulosum (Smith) A. Juss.)

P oll e n: Pollen grains 4-colporate, prolate-spheroidal (40-45 $\mu \mathrm{m}$; amb rounded). Apocolpium large. Ora lalongate. Exine smooth, thickened at the apertures.

S e c o nd a r y x y l e m: Vessels in radial rows of $(2)_{3}$ or $4(6)$, tangential diameter $60-\mathrm{I} 60 \mu \mathrm{m}$; intervascular pits $4.5 \mu \mathrm{m}$; gum present. Ray tissue heterogeneous Kribs Type 3; rays I- or 2-seriate, up to Is cells high, the heterocellular with I marginal row. Fibres septate. Parenchyma ${ }^{\star}$. Paratracheal: confluent and banded; crystals absent. Apotracheal: terminal bands present.

\footnotetext{
* Note: The parenchyma is very abundant, and it is difficult to distinguish between that associated with the vessels and that which is unassociated.
} 
D i s t r i b u t i o n: One or two species in eastern Australia.

T y p e s p e ci es: $S$. glandulosum (Smith) A. Juss.

Relat i o n s i ps: Synoum is closely related to Guarea and Dysoxylum but may be distinguished from both by the presence of the arillode which unites the two seeds of each locule, a situation unknown elsewhere in the family. Synoum has leaves bearing a terminal leaflet and flowers which lack a stipitate disk. These features are rarely encountered in Guarea. The staminal tube of Guarea is often shortly cylindrical, never cyathiform as in Synoum.

Synoum differs from all species of Guarea examined by us in having prolate-spheroidal pollen grains ( $100 \mathrm{P} / \mathrm{E}=108)$. Those of Guarea are oblate-spheroidal or spheroidal ( $100 \mathrm{P} /$ $E=93-100)$. The pollen grains of Synoum also differ in having equatorially elongate pores; those of Guarea are circular.

The secondary xylem of Synoum also shows a number of differences from that of Guarea. These are: the absence of crystals in chambered parenchyma cells and the presence of apotracheal banded parenchyma. In addition, heterogeneous ray tissue, characteristic of Synoum, is only rarely found in Guarea.

Synoum differs from all species of Dysoxylum known to us in lacking a cyathiform or tubular disk. The staminal tube of Dysoxylum is rarely shortly cylindrical, never cyathiform as in Synoum. The pollen grains of these two genera are not significantly different. The secondary xylem of the two genera is similar except that the absence of crystals in the parenchyma of Synoum distinguishes the latter from all species of Dysoxylum but for $D$. acufangulum Miq., which differs in other respects.

The relationships of Synoum with Pseudocarapa and Anthocarapa are discussed under the respective genera.

\section{ANTHOCARAPA}

Anthocarapa Pierre, Fl. Forest. Cochinchine s (1897) sub t. 343; Harms in Engl, \& Prantl, Nat. Pflanzenfam., ed. 2, 19 bI (1940) 166. - Fig. 13b, c.

Amoora sect. Pseudo-Guarea C. DC. in A. \& C. DC., Monogr. Phan. I (1878) 590 pro parte quoad A. nitidula Benth., $A$. balanseana C. DC. et $A$. vieillardii C. DC. tantum.

Trees with paripinnate leaves. Indumentum of simple hairs. Leaflets without pellucid lines or dots. Flowers unisexual (plants dioecious), in axillary panicles. Calyx 4- or 5-lobed to the middle or below. Petals 5 , free, imbricate. Staminal tube $0.2-0.25 \mathrm{~cm}$ long, cyathiform; margin with IO-I2 truncate or emarginate appendages. Anthers glabrous, alternate with the appendages, inserted within the throat of the staminal tube and partly exserted; antherodes similar, without pollen, not dehiscing. Disk in male flowers thick, fleshy, annular or patelliform, surrounding the pistillode; in female flowers small, annular, and confined to the base of the ovary. Ovary (2)3-locular; loculi uniovulate, placentation axile. Style-head discoid. Pistillode slender, immersed in the disk; vestigial ovules present. Fruit a tardily dehiscent, 2- or 3-valved, loculicidal capsule; pericarp thick and rather woody. Seed with a non-vascularised sarcotesta. Embryo with thick collateral cotyledons; radicle superior, included.

P o 11 e n: Pollen grains $4(5)$-colporate, prolate-spheroidal $(35-40 \mu \mathrm{m}$, amb rounded to quadrangular). Apocolpium medium. Ora lalongate. Exine smooth, thickened at the apertures.

$\mathrm{S}$ e c o n d a r y $x$ y $1 \mathrm{e} \mathrm{m:} \mathrm{Vessels} \mathrm{solitary} \mathrm{and} \mathrm{in} \mathrm{radial} \mathrm{groups} \mathrm{of} 2-4(8)$; tangential diameter 40-100 $\mu \mathrm{m}$; intervascular pits $3 \mu \mathrm{m}$; gum absent. Ray tissue homogeneous Kribs Type I or heterogeneous Kribs Type 3; rays I or 2(3)-seriate, up to 30 cells high, the 

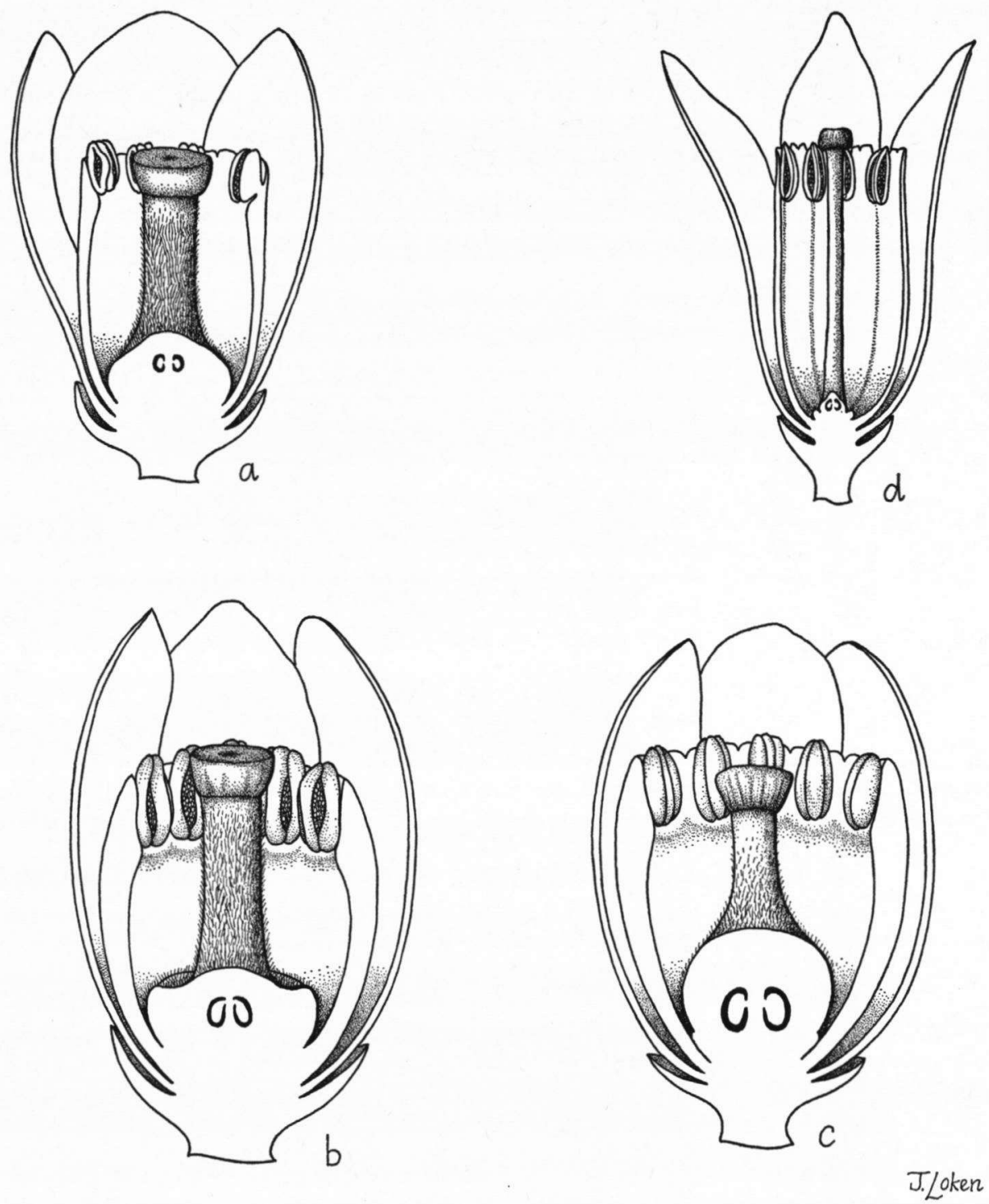

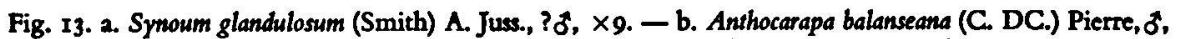
$\times$ Is. - c. A. sp., \&, XIs. - d. Pseudocarapa championii (Hook. f. \& Thoms. ex. Thwaites) Hemsl., \$, X9. (2. Constable s.r.; b. Pennington 8136; c. White 12867; d. Walker s.n.). 
heterocellular with I marginal row. Fibres: septate. Parenchyma. Paratracheal: banded, with crystals.

$\mathrm{D}$ is $\mathrm{tr} \mathrm{ib}$ u $\mathrm{t}$ i on: Two or three species in Australia, New Guinea, and New Caledonia.

T y pe s p e ci es: $A$. balanseana (C. DC.) Pierre (here chosen as lectotype).

$\mathrm{R} \mathrm{e} \mathrm{lat} \mathrm{i} \mathrm{o} \mathrm{s} \mathrm{h}$ i p s: All three species of this genus were originally placed in Amoora, where they remained until 1897 when Pierre transferred the two New Caledonian species ( $A$. balanseana C. DC. and $A$. vieillardii C. DC.) to his new genus Anthocarapa. The third species, $A$. nitidula Benth. from Australia, was left in Amoora by Pierre, but it was removed, in our opinion mistakenly, to Pseudocarapa by Merrill and Perry in 1940. In the same year Harms followed Pierre's circumscription of Anthocarapa, but also suggested that Amoora nitidula Benth. should be placed there, without expressing a firm opinion.

It is clear to us that these three species should belong to the same genus, since they share the following important characters: a corolla with imbricate aestivation, a cyathiform staminal tube, an annular or patelliform disk, uniovulate loculi, and a capsular fruit containing a seed with a sarcotesta.

Anthocarapa differs from Amoora in many characters. The indumentum is simple (not stellate); the staminal tube is terminated by appendages; it has an annular or patelliform disk (absent in Amoora); it has a long style surmounted by a discoid style-head (style short or absent, style-head never discoid in Amoora).

The morphological evidence shows it to be much more closely related to Guarea, Synoum, Dysoxylum, and Pseudocarapa. The characters that separate it from Guarea are the absence of the dormant terminal bud or terminal leaflet on the leaves and the annular or patelliform disk (not stipitate).

It may be distinguished from Synoum by the paripinnate leaves, the staminal tube appendages, the uniovulate loculi, and exarillate seeds. Characters constant in Anthocarapa but rarely seen in Synoum are: number of petals 5 (nearly always 4 in Synoum); number of anthers io (nearly always 8 in Synoum).

Anthocarapa differs from all species of Dysoxylum in having an annular disk (not cyathiform or tubular), and the staminal tube of Anthocarpa differs from that of all species of Dysoxylum in being cyathiform (not tubular).

The pollen grain characteristics of Anthocarapa exclude it from Amoora, but the 4colporate prolate-spheroidal grains are similar to those of many species of Dysoxylum and to those of Synoum.

The secondary xylem provides additional evidence for discounting Amoora as a closely related genus. Amoora characteristically has sparse, vasicentric and aliform parenchyma, but in Anthocarapa it is abundant and exclusively banded, very similar to that of Dysoxylum or Guarea.

The differences between Anthocarapa and Pseudocarapa are discussed in detail under the latter.

\section{PSEUdocarapa}

Pseudocarapa Hemsl. in Hook. Ic. Pl. (1884) t. 1458; Harms in Engl. \& Prantl, Nat. Pflanzenfam., ed. 2, 19 bI (1940) I39. - Fig. I3d.

Amoora sect. Pseuda-Guarea C. DC. in A. \& C. DC., Monogr. Phan. I (1878) 591 pro parte quoad $A$. championii (Hook. f. et Thoms.) C. DC. tantum.

Trees with paripinnate leaves. Indumentum of simple hairs. Leaflets without pellucid lines or dots. Flowers bisexual, in axillary panicles. Calyx 4 -lobed to the middle. Petals 3 or 4, 
free, valvate at least in the lower half, sometimes imbricate at the apex. Staminal tube $0.4-0.6 \mathrm{~cm}$ long, cylindrical, the margin with 8 short emarginate appendages. Anthers glabrous, alternate with the appendages, inserted within the throat of the staminal tube and partly exserted. Disk annular or patelliform, fused to the base of the ovary. Ovary (2)3- or 4-locular; loculi with 2 collateral ovules, placentation axile. Style-head narrowly discoid, with a central depression. Fruit a 3- or 4-valved loculicidal capsule, the loculi (I) 2 -seeded. Pericarp rather hard. Seed with a fleshy arillode on the adaxial side. Embryo with thick collateral cotyledons; radicle superior, extending to the surface.

P o 11 e n: Pollen grains in rhomboidal tetrads. Individual grains 3-colporate, ? spheroidal (30-35 $\mu \mathrm{m}$; amb rounded). Apocolpium large. Ora circular. Exine smooth, thickened at the apertures.

S e cond a r y x y lem: Vessels solitary and in radial groups of 2 or 3(4); tangential diameter 80- $140 \mu \mathrm{m}$; intervascular pits $4.5 \mu \mathrm{m}$; gum absent. Ray tissue heterogeneous Kribs Type 3; rays $\mathrm{I}-3$-seriate, up to 30 cells high, the heterocellular with I marginal row. Fibres: septate. Parenchyma. Paratracheal: vasicentric, aliform and confluent, without crystals.

$\mathrm{D}$ is $\mathrm{t} \mathbf{r} \mathrm{ib}$ u $\mathrm{t}$ i o n: One species in Ceylon, with perhaps one in New Guinea, and one undescribed species in the Philippines.

Ty pe speci es: $P$. championii (Hook. $f$. \& Thoms. ex Thwaites) Hemsl.

$\mathrm{Rel}$ ation ships: The type species of this genus has been placed in three genera. It was originally described as Dysoxylum championii by Hooker $f$. and Thomson (I864), but C. de Candolle (1878) transferred it to section Pseudo-Guarea of Amoora. Six years later, Hemsley, who was dissatisfied with both these treatments, suggested that it belongs in a distinct genus, Pseudocarapa. Harms accepted Hemsley's view, and placed Pseudocarapa in the Guareinae next to Synoum.

This genus is most closely related to Dysoxylum from which it differs in having an annular or patelliform disk (not cyathiform or tubular). Its pollen differs from that of Dysoxylum in being shed in rhomboidal tetrads. Pollen shed in tetrads is unknown elsewhere in the Meliaceae.

It differs from Amoora in many features: its simple indumentum (not stellate); its valvate corolla (not imbricate); its cylindrical staminal tube bearing appendages (not cyathiform or globose); its disk (Amoora has no disk); its long style and discoid style-head (style short or absent, style-head never discoid in Amoora).

Pseudocarapa is also related to Guarea, Synoum, and Anthocarapa. The following characters distinguish it from Guarea: leaves without a terminal bud or leaflet, disk annular or patelliform (not stipitate), ovules collateral (not superposed), seed arillodiate (no sarcotesta as in Guarea.)

It may be separated from Synoum by the paripinnate leaves, valvate petals, appendages on the staminal tube, and the absence of the common arillode uniting two seeds in each loculus.

Pseudocarapa differs from Anthocarapa in a number of characters, which may be referred to in the key.

The wood anatomy of Pseudocarapa is of a type rarely found in Dysoxylum and allied genera. The rather sparse paratracheal parenchyma has been observed in only two species of Dysoxylum, $D$. acutangulum Miq. and the species represented by Pennington 7881 from Sabah. It is, however, quite frequently present in species of Amoora, but this cannot be regarded as significant as there are so many morphological differences between these two genera.

N o te s: (I) The taxonomic position of $P$. papuana Merr. and Perry is uncertain. Harms 
(1942) transferred it to Aglaia on account of the minute flowers, but it differs from that genus in the simple indumentum, valvate corolla, the presence of a disk, and the discoid style-head. The pollen grains are also larger than those of most species of Aglaia and 4-colporate; those of Aglaia are almost consistently 3-colporate.

The minute unisexual flowers, densely hairy cyathiform staminal tube, uniovulate loculi, and pollen grains which are shed singly are also quite distinct from Pseudocarapa. In the latter character it resembles the genus Anthocarapa.

Until fruits of this species are collected it is not possible to place it with any certainty.

(2) We have not been able to examine any material of $P$. inopinata Harms, the third species of this genus..

(3) The species represented by Loher 255 from the Philippine Islands possibly belongs in Pseudocarapa. The specimen, which bears male flowers only, shares the majority of the leaf and flower characters of the genus, but female flowers and fruit are needed to confirm its relationships. The pollen grains of this species are shed singly, not in tetrads as in $P$. championii.

\section{DYSOXYLUM}

Dysoxylum Blume, Bijdr. (1825) 172; Harms in Engl. \& Prantl, Nat. Pflanzenfam. ed. 2, 19 bl (1940) I 60 t. 35 figs. F-J. - Fig. Isa-d.

? Ricinocarpodendron Boehm. in Ludwig, Definit. Gen. P1, ed. Boehmer (1760) 512.

Alliaria [Rumph., Herb. Amb. 2 (174I) 8I, t. 20] O. Kuntze, Rev. Gen. I (189I) 108; non Fabricius (1759), nec Scopoli (1760).

[? Harpagontia Noronha, Verh. Batav. Gen. s(2) (1790) 64, nom. nud.]

Epicharis Blume, op. cit. I66; Harms, tom. cit. 167, t. 35 figs. K, N-Q.

Didymocheton Blume, op. cit. I77; Harms, tom. cit. I56, t. 35 figs. L-M.

Hartigshea A. Juss., Mém. Mus. Hist. Nat. Par. I9 (1830) 227.

Cambania Comm. ex M. J. Roem., Synops. Monogr. Hesperid. I (1846) 83, 102.

Prasoxylon M. J. Roem., tom. cit. 83, 101.

Macrochiton M. J. Roem., tom. cit. 84, 104.

Disyphonia Griff., Not. 4 (1854) 504, in obs., nomen provisorium.

[Meliadelpha Radlk., Sitzungsber. Bayer. Akad. 20 (1890) 33I, in obs., nom. nud.]

Trees or treelets. Indumentum of simple hairs. Leaves pinnate, rarely with limited apical growth. Leaflets without pellucid lines or dots. Flowers bisexual or unisexual (plants dioecious), in axillary panicles, often narrow and racemose or thyrsoid, more rarely spicate, occasionally ramiflorous or cauliflorous; flowers sometimes subtended by several imbricate bracts. Calyx rarely entire, usually shallowly or deeply $3-5(6)$-lobed, or sepals free, or calyx closed in bud, splitting to produce an irregular margin and then circumscissile at the base; aestivation open or imbricate. Petals $3-6$, free or fused to the lower or upper half of the staminal tube, imbricate or valvate. Staminal tube $0.2-2.3 \mathrm{~cm}$ long, cylindrical, margin entire, crenate, irregularly toothed, or terminated by $6-\mathrm{IO}\left(\mathrm{I}_{3}\right)$ short, obtuse, truncate, emarginate, or rarely bilobed appendages. Anthers glabrous or rarely hairy, alternate with the appendages, inserted within the throat of the staminal tube, completely included or partly exserted. Disk free, long- or short-tubular, less frequently cyathiform, the margin often crenate or lobed. Ovary 2-5-locular; loculi with I or 2 collateral or superposed ovules, placentation axile. Style-head discoid, less frequently small and capitate. Fruit a 2-5-valved loculicidal capsule, the loculi I- or 2- seeded. Seed arillodiate or with a sarcotesta; arillode fleshy, partly or completely surrounding the seed, partly fused to the testa or free; sarcotesta adaxial or completely surrounding the seed. Embryo with thick, collateral, oblique or superposed cotyledons; radicle superior or adaxial, extending to the surface or included. 
G e r m in a t i o n: cryptocotylar or less frequently phanerocotylar, cotyledons often fugaceous; cataphylls sometimes present; eophylls usually opposite, rarely spirally arranged, simple, trifoliolate, or pinnate, entire or toothed (personal observations and Burger, 1972).

Chrom os ome numbers: $n=10,40,42 ; 2 n=80,84$.

P oll e n: Pollen grains (3) $4(5)$-colporate, oblate-spheroidal, spheroidal, or prolatespheroidal (30-60 $\mu \mathrm{m}$, amb rounded). Apocolpium large or medium. Ora circular or lalongate, rarely crassimarginate. Exine smooth or scabrous, thickened at the apertures.

$\mathrm{Se}$ c o n d a $\mathrm{r}$ y $x$ y l e m: Vessels solitary and in radial rows of $2-4(6)$, with rare pore clusters; tangential diameter $40-240 \mu \mathrm{m}$; intervascular pits $3.5-7.5 \mu \mathrm{m}$; gum usually present. Ray tissue usually heterogeneous Kribs Type 3 or homogeneous Kribs Type 1, rarely heterogeneous Kribs Type 2 or uniseriate-homogeneous or -heterogeneous; rays I-3(4)-seriate, up to 70 cells high, the heterocellular with I-6 marginal rows. Fibres: septate. Parenchyma. Paratracheal: rarely vasicentric, occasionally aliform, usually confluent and banded, in various combinations; crystals usually present. Apotracheal: terminal bands rarely present. Diffuse crystalliferous cells occasionally present. Silica deposits are rarely present.

$\mathrm{D}$ i st $\mathrm{r}$ ib u tion: About 60 species from the Indo-Malayan region eastwards to Australia, New Guinea, and Polynesia. One species in New Zealand.

T y p e s p e c i es: $D$. alliaceum Bl.

$\mathrm{Rel}$ a t i o n s h i s: The genera Didymocheton Bl. and Epicharis Bl. have been treated as sections of Dysoxylum Bl. by several previous authors, including C. de Candolle ( 1878 ) and Harms ( 1896 ), but they were raised to generic rank by the latter in the second edition of Die Natïrlichen Pflanzenfamilien (I940).

Didymocheton was defined by the free sepals with imbricate aestivation and the flowers frequently subtended by a number of densely overlapping bracts. The calyx characters are not sufficiently clear-cut, as there are a number of borderline cases, e.g. Dysoxylum pilosum A. C. Smith and Dysoxylum spectabile Hook. $f$. where the calyx may be deeply divided or with free sepals and the aestivation open or imbricate. As these two characters do not appear to be correlated with any of the other variables - for example the fusion of the corolla to the staminal tube, presence or absence of an arillode, valvate or imbricate corolla lobes - there does not seem to be sufficient justification for keeping these species as a separate genus.

Epicharis was distinguished from Dysoxylum by Harms because its calyx is closed in bud and circumscissile at the base. However, some species, e.g. E. hierniana Harms (Dysoxylum cauliflorum Hiern) have been included in Epicharis although the calyx is neither closed in bud nor circumscissile at the base. Since other genera, e.g. Guarea and Chisocheton, may contain a few species which differ from the others in having a closed circumscissile calyx but do not differ in other respects, there seems to be no reason why Epicharis should not be united with Dysoxylum. If Epicharis is given generic rank, it would be logical to separate the circumscissile species of Chisocheton and Guarea also into segregate genera. In our opinion this would be unwise.

No additional evidence for maintaining Didymocheton or Epicharis as genera is obtained from the wood anatomy. Didymocheton and Dysoxylum sensu stricto are indistinguishable. Banded apotracheal parenchyma, which is rarely seen in Dysoxylum sensu stricto, occurs in the two species of Epicharis which we have examined, but an investigation of several samples of Epicharis caulostachya (Miq.) Harms revealed that this type of parenchyma was not always present.

Dysoxylum (including Didymocheton and Epicharis) differs from Chisocheton in one 

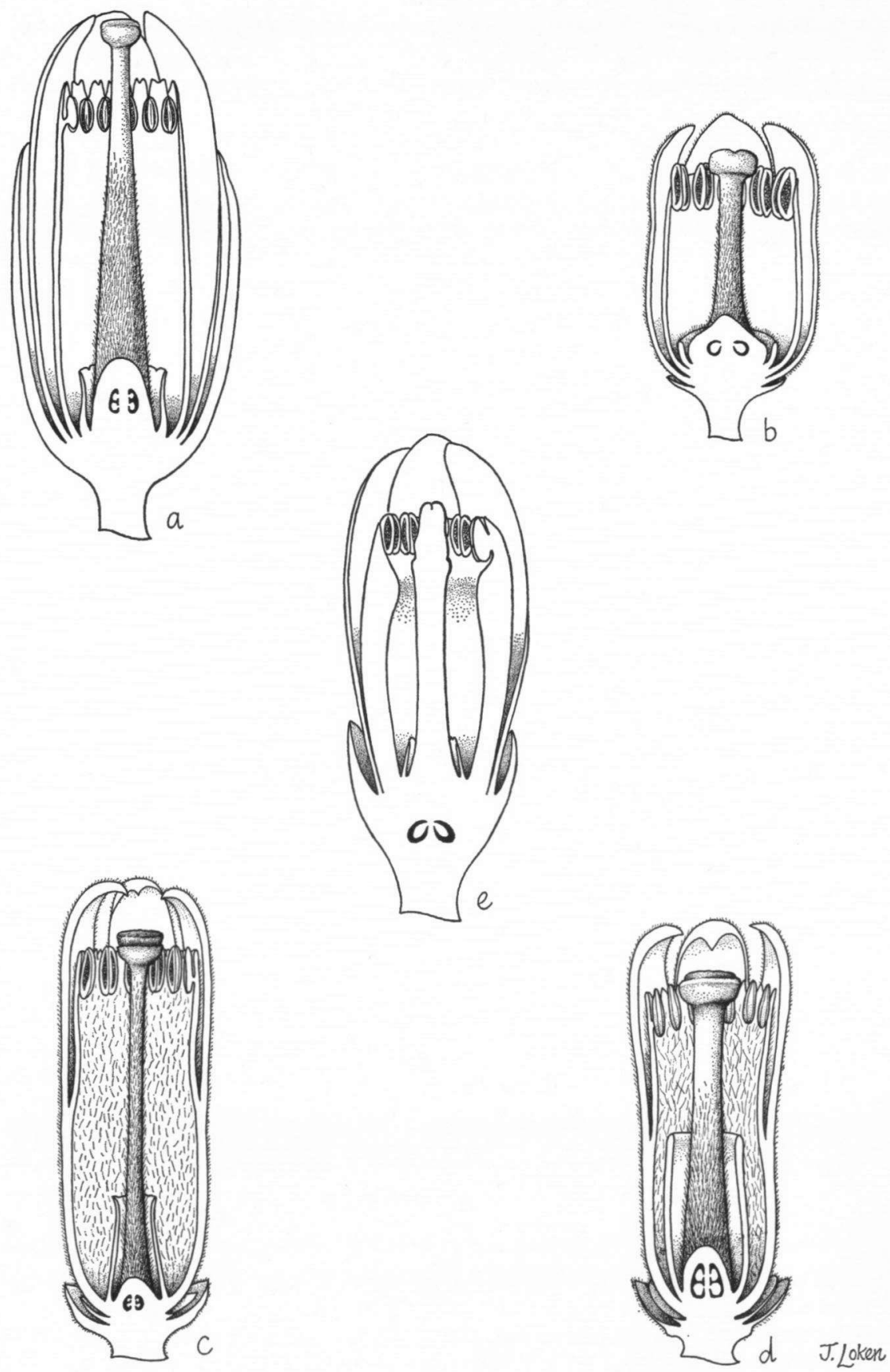

Fig. 14. a. Dysoxylum caulostachyum Miq., $\delta, \times 3 .-$ b. D. arborescens (Blume) Miq.,

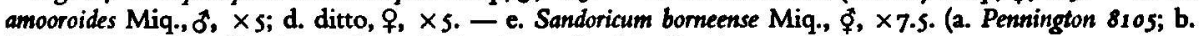
Pennington 7818; c. Pennington 8054; d. Pennington 8116; e. Pennington 7894). 
character: the presence of a cyathiform or tubular disk. The disk of Chisocheton, when present, is never more developed than stipitate or patelliform. This difference is supported by a few good differential characters, viz. absence of dormant terminal bud from the leaf and anthers which are not locellate, both of which exclude nearly all species of Chisocheton. Some species of Dysoxylum have the corolla fused to the staminal tube to half way or beyond, a condition never found in Chisocheton, and the seed of Dysoxylum is never scutiform with a large mealy-white hilum as it often is in Chisocheton.

Dysoxylum is closely related to Guarea but may be distinguished from it by one absolutely diagnostic character. In Guarea the disk is never cyathiform or tubular. Two additional characters support this distinction. Most species of Guarea have a dormant terminal bud on the leaf, a feature never present in Dysoxylum. In Guarea the corolla is nearly always free from the staminal tube, and only rarely fused to it at the base, whereas in Dysoxylum the corolla and staminal tube are often fused to halfway or above.

Silica is rarely found in the wood of Dysoxylum whereas it is nearly always present in Chisocheton and occasionally in Guarea. No other distinguishing features were discovered from the wood structure or pollen morphology.

The differences between Dysoxylum and Anthocarapa, Pseudocarapa, Cabralea, Synoum, and Sandoricum are discussed under the respective genera.

\section{Tribe 7. SANDORICEAE}

Tribus Sandoriceae, tribus nova.

Folia trifoliolata. Tubus stamineus cylindricus, supra costatus. Antherae intra fauces tubi staminei insertae. Discus tubularis. Caput styli stigmate profunde 4-vel 5 -lobato praeditum. Fructus drupaceus. Semen sine arillodio, sarcotesta praeditum, sine endospermio.

Typus tribus: Sandoricum.

Leaves trifoliolate. Indumentum of simple hairs. Flowers hermaphrodite. Staminal tube cylindrical, ribbed above. Anthers inserted within the throat of the staminal tube. Disk tubular. Style-head bearing a deeply $4^{-}$or 5 -lobed stigma. Fruit a drupe. Seed exarillodiate, with a sarcotesta, exendospermous. Cotyledons plano-convex, collateral.

P oll e n. Subprolate; $3(4)$-colporate; exine smooth or scabrous.

$\mathrm{S}$ e c o n d a r y $x$ y $1 \mathrm{em}$. Vessels solitary and paired; fibres non-septate; apotracheal terminal parenchyma absent; paratracheal parenchyma vasicentric to aliform.

\section{SANDORICUM}

Sandoricum Rumph. [Herb. Amb. I (1741) 167, t. 64] ex Cav., Dissert. 7 (1789) 359, t. 202, 203; Harms in Engl. \& Prantl, Nat. Pflanzenfam. ed. 2, 19 bI (1940) 170, t. 35 figs. A-E. - Fig. 140.

Trees. Flowers in axillary panicles, sometimes with cymose branching. Calyx almost truncate or shallowly 4 - or 5 -lobed. Petals (4) 5 , free, imbricate. Staminal tube $0.45-0.7$ cm long, terminated by ro short bilobed appendages. Anthers 10, glabrous, inserted opposite the appendages, completely included. Disk free, the margin coarsely toothed. Ovary slightly sunken in the calyx, 4- or s-locular; loculi with 2 collateral ovules. Style columnar, expanded above into a narrow annular style-head, bearing a 4- or s-lobed stigma on a thick cylindrical base. Fruit I-s-locular; the pyrenes I(2)-seeded; outer mesocarp rather dry-fleshy or rather soft and fibrous, inner mesocarp fleshy or spongyfibrous; endocarp thin and cartilaginous. Seeds bean-shaped, laterally compressed, with a 
sarcotesta; sarcotesta small and confined to the apex of the seed, or completely surrounding the seed and then thickened on the adaxial surface. Embryo with thick cotyledons; radicle superior, extending to the surface or slightly exserted.

$\mathrm{G}$ e r m i n a t i o n: phanerocotylar; eophylls opposite, trifoliolate.

Chromosome numbers: 2 n $=28$ ( $S$. radiatum King: Styles \& Khosla, unpublished); $2 n=16,32$ (S. indicum Cav.); $n=11,22$ (S. koetjape (Burm. f.) Merr.).

Poll e n: Pollen grains $3(4)$-colporate, subprolate $(45-60 \mu \mathrm{m}$; amb rounded to triangular). Apocolpium large or medium. Ora circular or lalongate, sometimes crassimarginate. Exine smooth or scabrous, thickened at the apertures.

S e c ond a r y x y l e m: Vessels solitary and in radial pairs; tangential diameter 40- $180 \mu \mathrm{m}$; pit size 3-4.5 $\mu \mathrm{m}$; gum present or absent. Ray tissue heterogeneous Kribs Type 2 or 3; rays I- 5 -seriate, up to 45 cells high, with I-4 marginal rows. Fibres nonseptate. Parenchyma. Paratracheal: vasicentric to aliform. Diffuse crystalliferous cells present or absent.

D istribution: Three to five rather variable species from the Indo-Malayan region to New Guinea.

T y p e s p e ci es: $S$. indicum Cav. $=S$. koetjape (Burm. $f$.) Merr.

$\mathrm{Re}$ a t i o n s h i s: Sandoricum is a very distinct genus placed after Dysoxylum by Harms on account of its free tubular disk. It has little else in common with this genus, and is at once identified by the trifoliolate leaves, the ribbed staminal tube, characteristic style-head with divided stigma, and the indehiscent drupaceous fruit.

The secondary xylem is also unlike that of Dysoxylum or of any other genus in the Guareeae. The very heterogeneous ray tissue, non-septate fibres, and sparse vasicentric or aliform parenchyma distinguish Sandoricum immediately.

The pollen grains are also distinctive by being almost consistently 3-colporate, a feature unknown in Dysoxylum and its related genera.

$N$ o t e: According to Harms, $S$. harmandii Pierre has $\mathbf{I}-5$-foliolate leaves. This species was described from fruiting material and the flowers are not known. Its position is uncertain.

\section{SUBFAMILY II. QUIVISIANTHOIDEAE}

Subfamilia Quivisianthoideae, subfamilia nova.

Gemmae nudae. Foliz spiraliter disposita. Planta dioecia vel flores hermaphrodita. Loculi (I) 2 ovulis praediti. Caput styli capitatum. Fructus capsularis, siccus, loculicide dehiscens; semen alatum.

Typus subfamiliae: Quivisianthe.

Buds naked. Leaves spirally arranged. Plants dioecious or flowers hermaphrodite. Loculi (I)2-ovulate, ovules collateral. Style-head capitate. Fruit a dry, loculicidal capsule; seed winged. Endosperm present.

\section{QUTVISIANTHE}

Quivisianthe Baill. in Grandidier, Hist. phys. natur. Madag. 33, tom. 3 (A tlas 2), fasc. 34 (1893) t. 25I; Harms in Engl. \& Prantl, Nat. Pflanzenfam., ed. 2., 19 bI (1940) 117. - Fig. I5a, b.

Trees with pinnate leaves. Flowers in short axillary panicles. Calyx s-lobed to halfway. Petals 5, free, valvate. Staminal tube $0.3-0.6 \mathrm{~cm}$ long, shortly cylindrical or urceolate, with an entire or shallowly lobed margin. Anthers 5 , hairy or glabrous, inserted on the margin of the staminal tube; antherodes much smaller, not dehiscing, without pollen. Disk annular or patelliform, fused to the base of the ovary and staminal tube, or absent 
and then the ovary and staminal tube on a short thick stipe. Ovary $3(4)$-locular. Pistillode similar. Style-head surmounted by a small obscurely 3-lobed stigma. Fruit 3(4)-valved, deeply $3(4)$-angled; loculi (I)2-seeded, thin but woody. Seed with a dry testa, flat, with a large wing at the upper end, attached to the placenta near the base of the wing; thin endosperm present. Embryo with flat collateral cotyledons; radicle superior, long, exserted.

P o 11 e n: Pollen grains 4(5)-colporate, spheroidal to prolate-spheroidal (35-45 $\mu \mathrm{m}$, amb rounded). Apocolpium small to medium. Colpi sometimes shortly bifurcate. Ora circular. Exine medium, smooth, not or only slightly thickened at the apertures.

S e condary y y le m: Not seen.

$\mathrm{D}$ is $\mathbf{t} \mathbf{r}$ b u t i o n: One or two species in Madagascar.

$T$ y pe species: $Q$. papinae Baill.

$\mathrm{Rel}$ at i o $\mathrm{nh}$ i ps: This genus, though occupying a very isolated position in a subfamily of its own, is similar in its floral structure to some genera in the tribe Trichilieae of the subfamily Melioideae. Harms (1940), who had not examined the fruit, placed it provisionally in the genus Trichilia. The complete staminal tube without appendages and with the anthers or antherodes inserted on the margin is also very similar to that of Ekebergia. However, the presence of the dry loculicidal capsule containing dry winged seeds immediately distinguishes it from these genera and indeed from all other members of the subfamily Melioideae.

\section{SUBFAMILY III. CAPURONIANTHOIDEAE}

Subfamilia Capuronianthoideae, subfamilia nova.

Gemmae nudae. Folia decussata. Planta monoecia. Loculi duobus ovulis evolutis et I vel 2 ovulis vestigialibus praediti.Caput styli capitatum. Fructus siccus pro parte septifrage dehiscens; semen sarcotesta corticosa.

Typus subfamiliae: Capuronianthus.

Buds naked. Leaves decussate. Plants monoecious. Loculi with 2 fully developed and I or 2 vestigial \pm superposed ovules. Style-head capitate. Fruit dry, with partial septifragal dehiscence; seed with a corky sarcotesta. No endosperm.

Se cond a r y x y l e m. Rays 2- or 3-seriate, partly heterogeneous. Crystals present in marginal ray cells. Paratracheal parenchyma sparse (vasicentric).

\section{CAPURONIAN'THUS}

Capuronianthus J. F. Leroy, Compt. Rend. Acad. Sci. Par. 247 (1958) I 374; Journ. Agric. Trop. Bot. Appl. S (1958) 762. - Fig. Isc, d.

Trees with pinnate leaves. Flowers unisexual in short axillary racemes or panicles. Calyx deeply 4 -lobed or of 4 free imbricate sepals. Petals $4(5)$, free, usually contorted, less frequently imbricate. Staminal tube $0.3-0.35 \mathrm{~cm}$ long, urceolate or shortly cylindrical, the margin with 8 deltate, ovate, or sometimes shortly bifid appendages alternating with the anthers. Anthers 8, glabrous, inserted on the margin of the staminal tube between the appendages, the base inside the throat, the apex exserted slightly beyond the appendages; antherodes much smaller, very slender, not dehiscing, and without pollen. Disk in male flowers a conspicuous swollen annulus fused to the base of the ovary; in female flowers reduced to an indistinct swelling round the base of the enlarged ovary, or absent; both sexes with a thin, patelliform, extra-staminal swelling fused to the base of the staminal tube. Ovary 2-4-locular; pistillode slender, with 3 or 4 ovules, either all vestigial or with 2 somewhat larger and better developed. Style very short or absent; style-head small. Fruit a 3- or 4-valved, shortly rostrate capsule with a short stipe; each valve I- or 

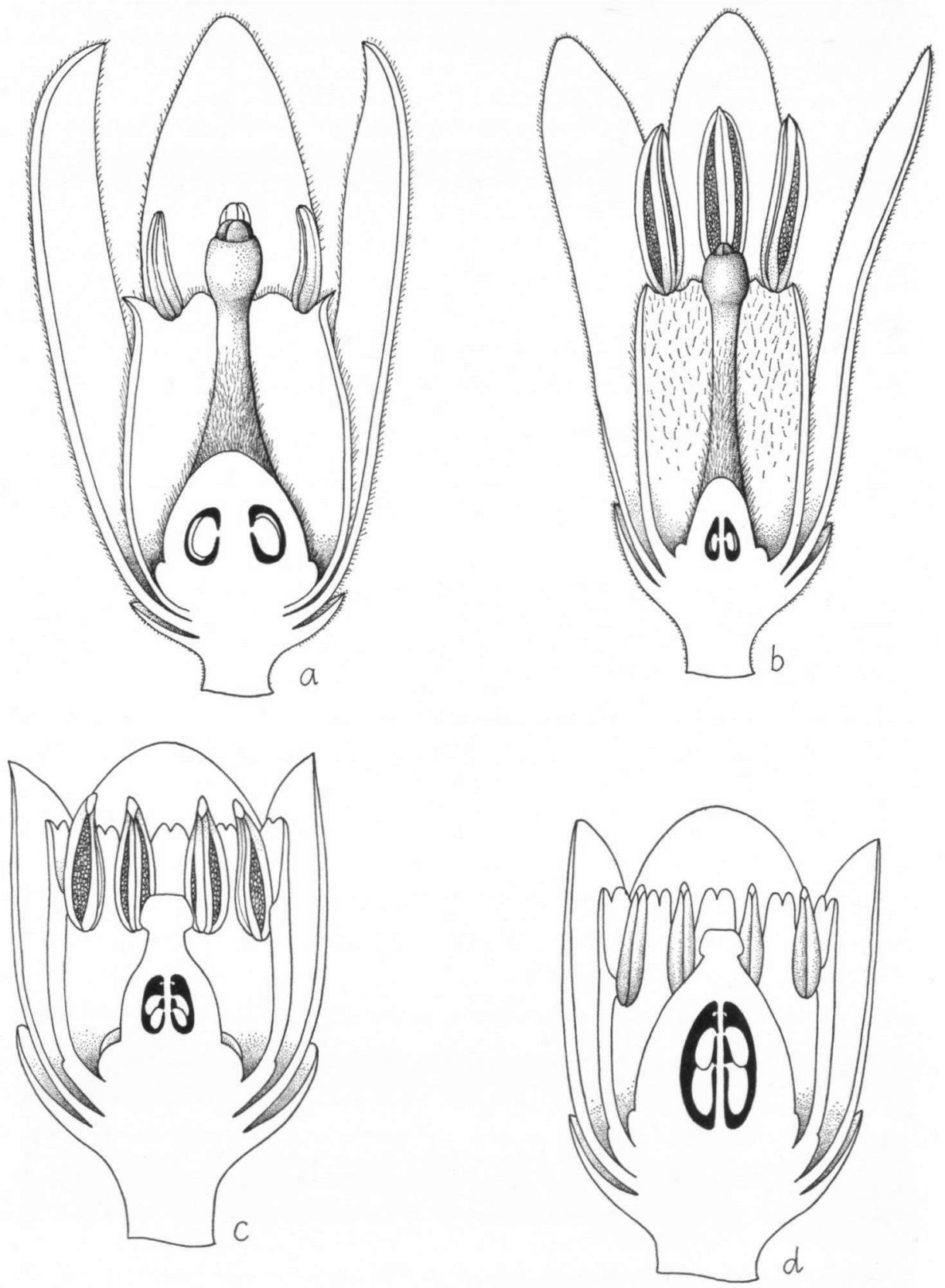

Fig. I5. a. Quivisianthe sp., $,+\times 12.5,-$ b. Q.sp., đ̊, $\times$ 12.5. - c. Capuronianthus mahafalensis J. F. Leroy, S., $\times 12.5$; d. ditto, $9 . \times 12.5$. (a. McWhirter 169; b. Capuron 9214; c, d. Capuron 27258). 
2-seeded; epicarp and mesocarp dry-fleshy and fibrous, dehiscing irregularly or indehiscent; endocarp cartilaginous, regularly dehiscent along the septa. Seed with a thick testa. Embryo with plano-convex collateral or oblique cotyledons; radicle superior or adaxial, extending to the surface or slightly projecting.

Ch r om os om e number: $2 \mathrm{n}=58$.

P oll e n: Pollen grains 4-colporate; subprolate (27-35 $\mu \mathrm{m}$; amb rounded). Apocolpium medium. Ora circular. Exine medium, smooth, unthickened or occasionally slightly thickened at the apertures.

$\mathrm{S}$ e c o n d a ry $\mathrm{x}$ y $1 \mathrm{e} \mathrm{m}$ : Vessels solitary and in radial rows of $2-4$, with some clusters. Tangential diameter $20-80 \mu \mathrm{m}$; intervascular pits $3-4.5 \mu \mathrm{m}$ : gum present. Ray tissue heterogeneous Kribs Type 3; rays 2- or 3-seriate, up to 25 cells high, the heterocellular with I marginal row. The marginal ray cells contain conspicuous crystals. Fibres nonseptate. Parenchyma. Paratracheal: vasicentric. Diffuse crystalliferous cells abundant.

$\mathrm{D}$ i s $\mathrm{tr}$ i b u t i o n: One species in Madagascar.

T y p e s pecies: C. mahafalensis J. F. Leroy.

Relationships: Although Capuronianthus is an isolated genus in the Meliaceae it appears to be distantly related to Carapa and Xylocarpus in the Swietenioideae. It shares with them both the partial septifragal dehiscence of the fruit, and the seed has the corky sarcotesta of $X y$ locarpus. Its chromosome number is the same as that of Carapa $(2 \mathrm{n}=58)$. However, in all other characters of subfamily importance it differs from these genera; moreover, in some floral characters it resembles very closely genera in the tribe Trichilieae of the subfamily Melioideae. The xeromorphic habit of the plant and the floral structure are similar to those of the endemic Australian genus Owenia. The loculi containing only 2 fully developed ovules and the capitate style-head are characteristic of many members of the Melioideae, although it must be pointed out that the presence of an additional vestigial ovule in the loculus rarely occurs in the latter subfamily.

In its secondary xylem Capuronianthus is intermediate between the Swietenioideae and the Melioideae. It possesses the crystals in the marginal ray cells of the former and the abundant crystals in chambered parenchyma cells and narrower rays of the latter. It is thus intermediate between the two subfamilies, but nevertheless quite distinct from both.

\section{SUBFAMILY IV. SWIETENIOIDEAE}

Buds nearly always protected by a cluster of scale-leaves. Leaves spirally arranged. Monoecious. Loculi nearly always with 3 or more ovules, these biseriate. Style-head discoid or very rarely capitate. Fruit a woody septifragal capsule, with a central columella; seed winged; capsule less frequently subwoody or leathery and then with a rudimentary columella and seed unwinged with a woody or corky sarcotesta.

P oll e n: subprolate or prolate-spheroidal; 4-colporate; exine smooth.

S e cond a r y x y l e m: Rays nearly always broad, (2) $3-6(7)$-seriate, and heterogeneous. Crystals usually present in marginal ray cells, often absent in wood parenchyma. Paratracheal parenchyma rather sparse (vasicentric or aliform).

\section{Tribe I. CEDRELEAE}

Flowers with an androgynophore (? disk) (very short in Toona); base of petals adnate to the androgynophore by a carina. Stamens 5 , free, sometimes together with a whorl of staminodes (Toona); appendages absent. Capsule woody or rarely membranaceous, with a soft columella; seeds winged at one or both ends; cotyledons flat, leaflike; residual endosperm present. 
P oll en and S e c ond a r y x y lem as for the subfamily.

I. Seeds winged below, attached by the seed towards the apex (distal end) of the central columella; androgynophore column-shaped, longer than the ovary; first leaflets of seedlings entire ................. 39. Cedrela

ra. Seeds winged at both ends, or if with one wing only then attached by the seed-end towards the base of the central columella (proximal end) and winged above; androgynophore cushion-shaped, shorter than or equalling the ovary; first leaflets of seedlings lobed or toothed

40. Toona

\section{CEDRELA}

Cedrela P. Browne, Hist. Jamaica (1756) 158, t. 1o fig. I; L., Syst. Nat. ed. ro (1759) 940; Harms in Engl. \& Prantl, Nat. Pfanzenfam. ed. 2, 19 bI (1940) 40, t. 2 A-C, K.; Earle Smith, Fieldiana, Botany 29 (I960) 295-34I. - Fig. I6a, b.

Cedrus Mill., Gard. Dict. ed. 7 (1759) (without pagination); non Trew (1757) nom. cons., nec Duham. (1755) nom. rejic.

Johnsonia Adans., Fam. PL. 2 (1763) 343. 564; non Mill. (1754) (=Callicarpa L.) nom. rejic., nec R. Br. (1810) nom. cons.

Pterosiphon Turcz., Bull. Soc. Nat. Mosc. 36 (1863) 589.

Deciduous trees. Leaves paripinnate (very rarely imparipinnate), leaflets entire, glabrous or with simple hairs. Flowers s-merous, unisexual, but with well-developed vestiges of the opposite sex present, borne in much-branched thyrses. Calyx lobed \pm to the base, shallowly dentate, or cup-shaped and split down one side. Petals 5 , free, longer than the calyx in bud, imbricate and adnate for $\frac{1}{2}$ of length to a long columnar androgynophore (? disk) by a median carina (thereby preventing their spreading in open flowers). Stamens $s$, free, adnate to the androgynophore below; anthers in $\delta$ flowers yellow and dehiscing, antherodes in of flowers shrivelled, brownish, and not producing pollen. No staminodes. Ovary 5-locular, borne at the apex of the gynophore, each loculus with 6-12 ovules; style short, style-head discoid with glandular stigmatic papillae. Pistillode in of flowers more slender, with well-developed loculi and a longer style, vestigial ovules very small. Fruit a pendulous (erect in one species, fide Earle Smith), thinly or thickly woody, obovoid or claviform, septifragal capsule, opening from the apex by 5 valves. Columella woody, sharply 5-angled, extending to the apex of the capsule, seed scars conspicuous. Seeds with a terminal wing attached by the seed-end to the distal part (apex) of the columella and winged towards the base of the capsule; with residual endosperm. Cotyledons collateral, flattened and leaf-like; radicle laterally exserted.

G e r m in a t i o n: phanerocotylar; eophylls opposite, trifoliolate, the leaflets sinuate, entire.

Chrom os om e numbers: $2 n=50,56$.

$\mathrm{D}$ is $\mathrm{t} \mathrm{r}$ ibution: About $\mathbf{s}$ poorly-defined species in the New World tropics, from Mexico to Argentina and in the Caribbean.

T y pe species: C. odorata L.

$\mathrm{Rel}$ a t i o n s $\mathrm{i}$ ps: The relationships of this genus with Toona are discussed after the latter.

\section{TOONA}

Toona (Endl.) M. J. Roem., Synops. Monog. Hesper. I (1846) 131, 139; Harms in Engl. \& Prantl, Nat. Pflanzenfam. ed. 2, I9 bI (1940) 44, t. 2 D-H, L. - Fig. I6c, d.

Cedrela sect. Toona Endl, Gen. P1. 2 (1840) ross.

Cuveraca Jones, Asiat. Res. 4 (1790) 281.

Surenus Rumph. [Herb. Amb. 3 (1743) 66, t. 39] ex O. Kuntze., Rev. Gen. I (I89I) IIo. 
Deciduous or semi-evergreen trees. Leaves paripinnate, sometimes imparipinnate, leaflets entire, serrate, or dentate; glabrous or with simple hairs. Flowers 5-merous, unisexual, but with well-developed vestiges of the opposite sex present, borne in muchbranched thyrses. Calyx free or (4)s-lobed. Petals 5 , free, longer than the calyx in bud, imbricate, adnate at the base by a carina to a short cushion-shaped androgynophore (? disk). Stamens 5 , free, arising from the androgynophore; anthers in oflowers yellow and dehiscing, antherodes in $\%$ flowers brown and shrivelled, not producing pollen; $\mathrm{I}-5$ thread-like staminodes sometimes present. Ovary s-locular, at the apex of the androgynophore, each loculus with 6-10 ovules; style short, style-head discoid with glandular stigmatic papillae. Pistillode in $\delta$ flowers more slender, with well-developed loculi and a longer style; vestigial ovules very small. Fruit a pendulous, membranaceous or thinly woody, ellipsoid or obovoid, septifragal capsule, opening from the apex by 5 valves. Columella softly woody, s-angled, extending to the apex of the capsule. Seeds either winged at both ends and attached towards the apex (distal end) of the columella or, if with a single wing, then attached by the seed-end to the base (proximal part) of the columella and winged above; with residual endosperm. Cotyledons collateral, flattened, and leaflike; radicle laterally exserted.

G e r m in a t i o n: phanerocotylar; eophylls opposite, trifoliolate, the leaflets deeply lobed or dentate.

C h r o m o s o m e n u m b e rs: $n=26,28,39 ; 2 n=46,52,56$.

Distribution: Approximately 6 poorly-defined species in the Old World eastwards from India to Australia.

T y p e s pecies: $T$. ciliata $M$. J. Roem.

$\mathrm{R}$ el a t i o n h i p s: Cedrela and Toona are clearly distinct from all other genera in the Swietenioideae and from almost all others in the family in possessing 5 free stamens and an androgynophore (? disk) to which they and the petals are attached. We believe that Roemer was justified in raising Endlicher's section Toona of Cedrela, containing the Old World species to generic rank, and most monographers have followed him. Although the two are closely related, they can be separated easily by a number of sound morphological characters. The androgynophore (? disk) is considerably longer (columnar) in Cedrela than in Toona and both stamens and petals are adnate to it for up to trd their length. In Toona it is patelliform and strongly resembles the disk in some other genera in Meliaceae, although the stamens appear to arise directly from it. A whorl of staminodes, which are never present in Cedrela, also occurs in some species. The capsules of Cedrela are always more strongly woody than in Toona, in which they tend to be delicate and membraneous. One species of Toona, T. microcarpa C. DC. does, however, have capsules with fairly thick woody valves with warty excrescences on the surface, reminiscent of $C$. odorata $\mathrm{L}$. Germination is identical in both genera, although the leaflets of the first leaves in Cedrela spp. are always entire; those of Toona are dentate, lobed, or variously divided. Chromosomal evidence suggests different evolutionary histories for the two genera.

\section{Tribe 2. SWIETENIEAB}

Flowers with or without a gynophore; petals free; stamens 8-ro, filaments partly or completely united into a cylindrical, urceolate, or bowl-shaped tube with or without appendages. Capsule woody, nearly always with a well-developed columella; the valves sometimes separating into an outer woody and an inner membranous layer. Seeds variously winged; cotyledons collateral, flattened; (residual) endosperm present.

Pollen and Secondar y x y lem as for the subfamily. 

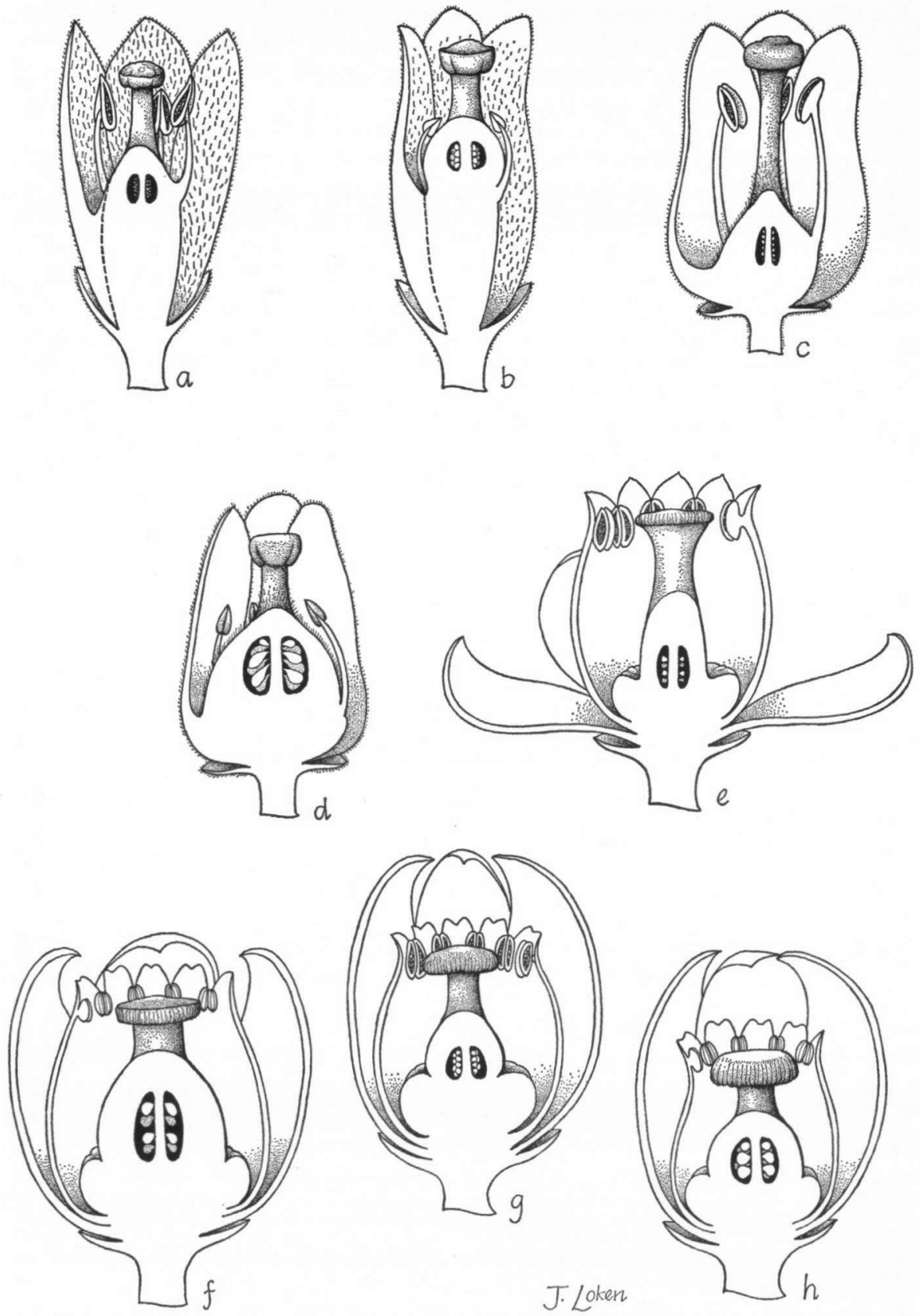

Fig. I6. a. Cedrela odorata L., ठే; b. ditto, ㅇ. - c. Toona ciliata M. J. Roem., ठే; d. ditto,

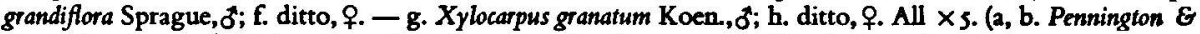
Sarukhdin 9650; c, d. Styles 266; e, f. Styles 177; g. Faulkner 1512; h. Hoogland 4302). 
I. Capsule globose, subglobose, or trigonous, not or scarcely longer than broad; seeds orbicular to suborbicular, winged all the way round.

2. Capsule globose or subglobose, dehiscing by $4-6$ valves which remain joined together at the base; wing of seed narrow, opaque . . . . . 4 4I. Khaya 2a. Capsule \pm trigonous, the valves falling separately at dehiscence; wing of seed broad and transparent ............ 42. Neobeguea

ra. Capsule elongate, at least twice as long as broad, ovoid, obovoid, ellipsoid, claviform, or fusiform; seeds with a single terminal wing or with a wing at both ends.

3. Seed with a wing at both ends, the upper (distal) wing the longer; anthers or antherodes inserted between the deltate teeth of the lobes of the staminal tube ................. 43. Soymida

3a. Seed with a single terminal wing.

4. Seeds very numerous, arranged laterally in tiers in each locule; margin of staminal tube entire or crenulate . . . . . . 45. Chukrasia

4a. Seeds up to 20 per locule, attached by the seed-or wing-end towards the proximal (base) or distal (apex) part of the columella; staminal tube with appendages or variously divided, very rarely entire.

5. Seeds attached by the seed-end towards the distal end (apex) of the columella (i.e. seed winged below).

6. Leaflets entire; capsule pendulous; valves lacking a fibrous network; staminal tube lacking appendages 44. Entandrophragma

6a. Leaflets undulately-lobed, crenate, serrate, or dentate; capsule erect, valves held together at dehiscence by a fibrous network.

7. Capsule claviform or oblong; anthers or antherodes inserted between the bifid teeth of the lobes of the staminal tube; connective not produced ..... 46. Pseudocedrela

7a. Capsule ellipsoid or fusiform; anthers or antherodes inserted between the lobes of the staminal tube; connective produced, much elongated and threadlike .. 47. Schmardaea

5a. Seeds attached by the wing-end towards the distal end (apex) of the columella (i.e. seed winged above).

8. Capsule large, erect, very woody, ovoid, oblong, or obovoid; flowers mostly s-merous . . 48. Swietenia

8a. Capsule pendulous, small, thinly-woody, ellipsoid or tetragonal; flowers 4-merous ..... 49. Lovoa

\section{I. KHAYA}

Khaya A. Juss., Mém. Mus. Hist. Nat. Par. I9 (?1830) 249. - Harms in Engl. \& Prantl, Nat. Pflanzenfam. ed. 2, I9 bl (1940) 49, t. 4 A-I, t. S. - Fig. 17a, b.

Garretia Welw., Apont. Phytog. (1859) 587; non Garrettia Fletcher (1937).

Deciduous trees. Leaves paripinnate, leaflets entire, glabrous. Flowers 4- or 5-merous, unisexual, but with very well-developed vestiges of the opposite sex present, borne in large, much-branched, axillary thyrses. Calyx 4- or 5-lobed almost to the base, the lobes subcircular, imbricate. Petals 4 or 5 , free, much longer than the calyx in bud, contorted, erect in open flowers, somewhat hooded. Staminal tube urceolate or cup-shaped, bearing 8-10 included anthers or antherodes towards the apex and terminated by 8-io subcircular, emarginate or irregularly lobed, overlapping appendages alternating with the anthers or antherodes. Disk in of flowers cushion-shaped, fused to the base of the pistillode, 
but free from the staminal tube; in 9 flowers \pm reduced to an indistinct swelling at the base of the ovary. Ovary 4- or 5-locular, each loculus with 12-16(-18) ovules. Stylehead thick, discoid with crenulate margin, almost completely blocking the entrance of the staminal tube, upper surface with minute receptive papillae and 4 or 5 radiating stigmatic ridges. Pistillode similar to the pistil but more slender and with a longer style; loculi well-developed, but vestigial ovules very small. Fruit an erect, (sub)globose woody, septifragal capsule, opening by 4 or $s(6)$ valves from the apex; valves remaining joined at the base; margins of valves often with rough fibrous strands. Columella not extending to the apex of the capsule, with 4 or $s(6)$ sharp, hard, woody ridges; seed scars white, conspicuous. Seeds 8-I8 per loculus, broadly transversely ellipsoid to suborbicular, narrowly winged all round the margin, residual endosperm present. Embryo with flattened collateral cotyledons; radicle lateral, slightly exserted.

G e r m in a t i o n: cryptocotylar; eophylls opposite, simple and entire, apex often long acuminate; later ones spirally arranged, trifoliolate or imparipinnate, often red.

Chrom os om e $\mathrm{n} \mathrm{umbers:} 2 \mathrm{n}=$ so ( 6 species).

$\mathrm{D}$ is $\mathrm{t} \mathbf{r}$ i b u $\mathrm{t}$ i o n: About 7 species, $s$ in tropical Africa and two in Madagascar and the Comores.

T y p e s p e ci es: $K$. senegalensis (Desr.) A. Juss.

Relationships: The relationships of this genus with Neobeguea are discussed under that genus.

\section{NEOBEGUEA}

Neabeguea J. F. Leroy, Compt. Rend. Acad. Sci. Paris (1958) 2641; Journ. Agr. Trop. Bot. Appl. 5 (1958) 594 [nom. illegit., gallice tantum descripta]; Journ. Agr. Trop. Bot. Appl. 17 (1970) 232. - Fig. 17c, d.

Deciduous trees. Leaves paripinnate, leaflets entire, crenate, or serrate, glabrous or with simple or dendroid glandular hairs. Flowers $4(5)$-merous, unisexual, but with well developed vestiges of the opposite sex present, borne in clustered thyrses either terminally or on short, lateral shoots. Calyx 4 -lobed to about the middle or less. Petals $4(5)$, free, contortedimbricate, much longer than the calyx in bud, reflexed in open flowers. Staminal tube urceolate or cup-shaped, bearing 8(10) included or slightly exserted anthers or antherodes on the inner surface towards the apex and terminated by 8-1o bifid appendages. Disk in $\delta$ flowers cushion-shaped, fused to the base of the pistillode, but free from the staminal tube; in of flowers reduced to an indistinct swelling at the base of the ovaray. Ovary 3locular, each loculus with $4-6$ ovules. Style-head thick, discoid with a swollen receptive surface. Pistillode similar to the pistil but more slender and with a longer style; receptive surface not differentiated; loculi well-developed but vestigial ovules very small. Fruit an erect (fide Leroy), \pm trigonous, 3-valved, woody, septifragal capsule, opening from the apex, valves falling singly. Columella woody, with 3 sharp ridges, extending to the apex of the capsule; seed scars inconspicuous. Seeds 3 or 4 per loculus, subcircular, flattened and broadly winged round the margin; residual endosperm present. Embryo with flattened somewhat collateral cotyledons; radicle obliquely superior or slightly laterally exserted.

G e r $\mathbf{m}$ in a $\mathbf{t}$ i o n: phanerocotylar, the cotyledons cordate, becoming green; eophylls simple, opposite, with a serrate margin; hypocotyl somewhat swollen.

Ch r o m os o m e n u m be r s: $2 \mathrm{n}=50,52$ ( $N$. mahafalensis J. F. Leroy).

$\mathrm{D}$ is $\mathrm{t} \mathbf{r}$ i b u t i o n: 3 species in Madagascar.

T y p e s p e ci es: $N$. ankaranensis J. F. Leroy.

$\mathrm{Re}$ la $\mathrm{t}$ i o $\mathrm{n}$ h i p s: Neobeguea is clearly closely related to Khaya. It demonstrates an interesting reduction from the latter in the number of its floral parts (flowers 4- or 5- 

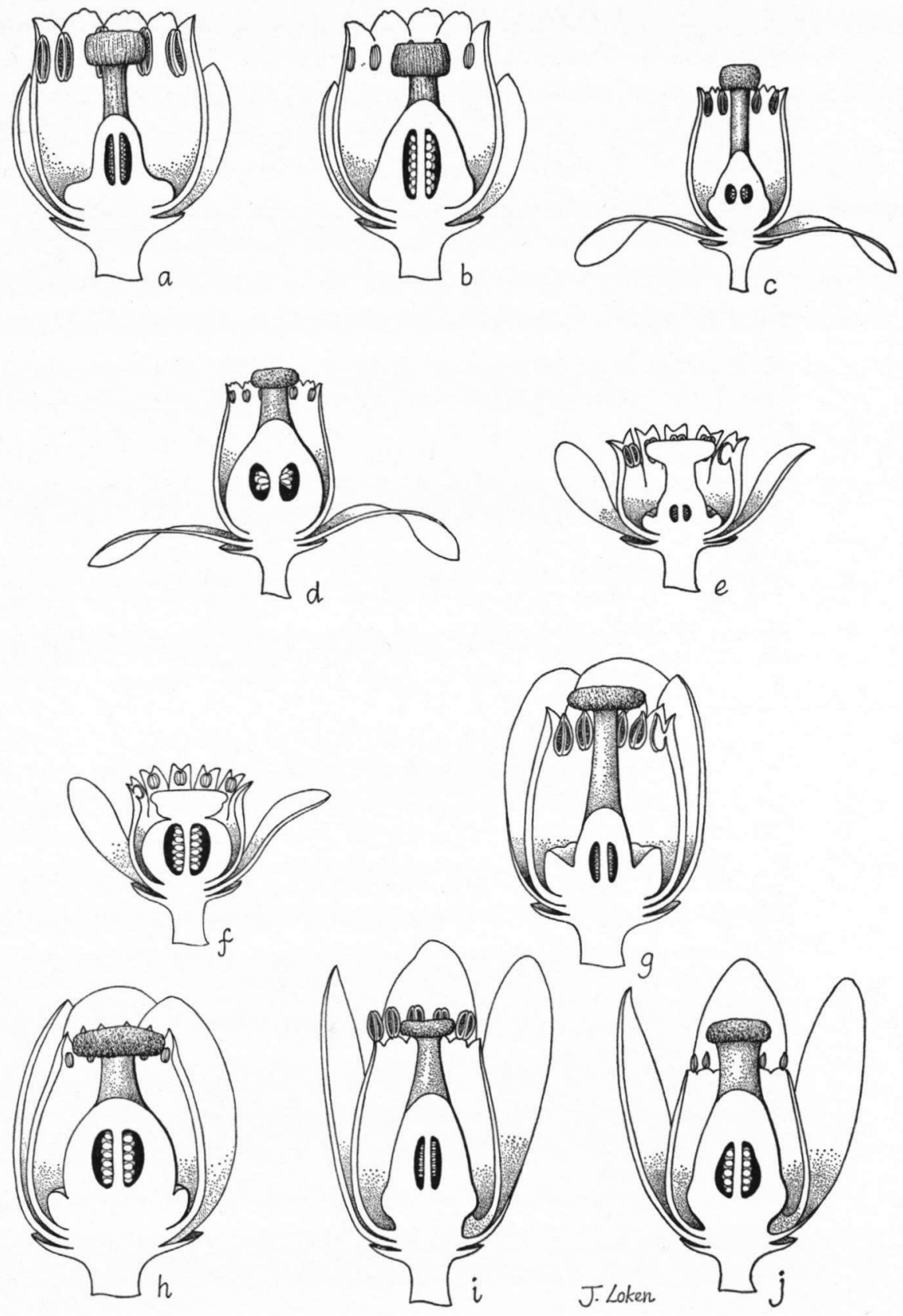

Fig. 17. 2. Khaya anthotheca (Welw.) C.D., ठ; b. ditto, 9. - c. Neobeguea mahafalensis J. F. Leroy, ơ; d. ditto, ․ - - e. Soymida febrifuga (Roxb.) A. Juss., ơ; f. ditto, +. - g. Swietenia humilis Zucc., ö; h. ditto, ‥ i. Entandrophragma excelsum (Dawe \& Sprague) Sprague, $\delta^{*} ;$ j. ditto, + . All $\times$ s. (a, b. Styles 399; c. d, McWhirter a44; e, f. Beddome s.n.; g. h, Styles 91; i, j. Styles 252). 
merous in Khaya, 4-merous in Neobeguea); in the number of locules and ovules in the ovary (4-6 locules with up to 18 ovules per loculus in Khaya, 3 locules each with up to 6 ovules in Neobeguea); and in the greater degree of fusion of the sepals (free in Khaya, fused \pm to the middle in Neobeguea). Seed structure is more specialized than in Khaya, the seed of Neobeguea having a broader, diaphanous wing and smaller embryo.

The pollen of Neobeguea is similar to that of other members of the Swietenioideae and the characters of its secondary xylem are shared by related genera.

\section{SOYMIDA}

Soymida A. Juss., Mém. Mus. Hist. Nat. Paris 19 (?1830) 25I t. 22; Harms in Engl. \& Prantl, Nat.Pflanzenfam. ed. 2, 19 bI (1940) 54 , t. 4 K-M. - Fig. I7e, f.

Deciduous trees. Leaves paripinnate; leaflets entire, glabrous. Flowers 5-merous, unisexual, but with well-developed vestiges of the opposite sex present, borne in muchbranched terminal or axillary thyrses. Calyx 5 , the sepals \pm free to the base, imbricate. Petals 5, with a short claw, contorted, spreading in open flowers. Staminal tube urceolate or cup-shaped, somewhat thickened towards the apex, and terminated by Io bifid spreading lobes; the anthers or antherodes inserted between the deltate teeth of the lobes. Disk in o flowers shallowly patelliform, fused to the base of the pistillode; in of flowers reduced to an indistinct swelling below the ovary. Ovary 5-locular, each loculus with 12-16 ovules; style absent; style-head discoid, much expanded, \pm completely blocking the entrance to the staminal tube; receptive surface differentiated into 5 lobes. Pistillode similar to the pistil but with a slender style and less glandular style-head; loculi well-developed, vestigial ovules very small. Fruit an erect, woody, ovoid, oblong, or obovoid, s-valved, septifragal capsule, opening from the apex, the valves separating into two layers. Columella woody, with 5 sharp ridges, extending to the apex of the capsule; seed scars inconspicuous. Seeds up to I2 per loculus, oblong or slightly curved, unequally winged at both ends and attached to the apex (distal end) of the columella by the longer wing; endosperm present as a residual layer. Embryo with flattened foliaceous cotyledons; the radicle obliquely superior.

G e rm in a t i o n: phanerocotylar; the cotyledons cordate at the base, becoming green; eophylls simple, opposite or spirally arranged; the margin minutely serrate; later ones trifoliolate.

Chromosome number: $2 n=56$.

$\mathrm{D}$ is $\mathrm{t} \mathbf{r} \mathrm{ib}$ u $\mathrm{t}$ i on: One species in India and Ceylon.

T y p e s p e ci es: $S$. febrifuga (Roxb.) A. Juss.

$\mathrm{Rel} \mathrm{at} \mathrm{i} \mathrm{o} \mathrm{n} \mathrm{h} \mathrm{i} \mathrm{p} \mathrm{s:} \mathrm{Soymida} \mathrm{is} \mathrm{extremely} \mathrm{similar} \mathrm{to} \mathrm{some} \mathrm{species} \mathrm{of} \mathrm{Khaya} \mathrm{in} \mathrm{its} \mathrm{leaf}$ morphology. The flowers also appear similar except that the petals are spreading (erect in Khaya) and the appendages of the staminal tube are regularly bifid (subcircular or irregularly lobed in Khaya). The seed is also very similar. In Soymida the wing is unequally elongated at each end, whereas in Khaya the seed is winged \pm equally all the way round the circumference. The bilamellate structure of the capsule is perceptible in Khaya although the valves do not separate into two distinct layers as in Soymida.

\section{ENTANDROPHRAGMA}

Entandrophragma C. DC., Bull. Herb. Boiss. 2 (1894) 582, fig. 21, 55, t. 6-10; Harms in Engl. \& Prantl, Nat. Pflanzenfam. ed. 2, 19 bI (1940) 55, fig. 6. - Fig. 17i, j.

Wulfhorstia C. DC., Mém. Herb. Boiss. Io (1900) 77.

Leioptyx Pierre ex De Wild., Ann. Mus. Congo Belge, Bot. 5 (2) (1908) 258.

Heimodendron Sillans, Bull. Soc. Bot. France 100 (1953) 263. 
Deciduous trees. Leaves paripinnate, leaflets entire, glabrous or with simple hairs. Flowers 5-merous, unisexual, but with well-developed vestiges of the opposite sex present, borne in much-branched thyrses. Calyx \pm entire and cupular or 5-lobed to half-way or almost to the base, the lobes acute; aestivation open. Petals 5 , free, contorted, much longer than the calyx in bud, reflexed or patent in open flowers. Staminal tube urceolate or bowl- or goblet-shaped, the margin entire, shallowly or deeply lobed, with Io anthers or antherodes borne on short filaments on the margin of the tube or its lobes; appendages absent. Disk in of flowers cushion-shaped, fused to the base of the ovary or pistillode but free from the staminal tube and connected to it by 10 or 20 short ridges or partitions (sometimes obscure in $q$ flowers). Disk in $q$ flowers \pm reduced to an indistinct swelling at the base of the ovary. Ovary 5-locular, each loculus with 4-I2 ovules. Style-head discoid with 5 radiating stigmatic lobes, \pm completely blocking the entrance to the staminal tube. Pistillode similar to the pistil but more slender and with a longer style, style-head often projecting from the apex of the tube; loculi well-developed, but vestigial ovules very small. Fruit a pendulous, elongate, woody, cigar-shaped, fusiform, cylindrical or claviform, septifragal capsule opening by $s$ valves from the apex or base or from the apex and base simultaneously. Columella softly woody, extending to the apex of the capsule, 5-angled or 5-ridged, deeply indented with the imprints of the seeds; seed-scars conspicuous or inconspicuous. Seeds with a terminal wing, 3-9 per loculus, attached by the seed-end to the distal part of the columella and winged towards the base of the capsule; residual endosperm present as a thin layer. Embryo with thin cotyledons; radicle laterally exserted.

$\mathrm{G}$ e r $\mathrm{m}$ i $\mathrm{n}$ a $\mathrm{t}$ i o $\mathrm{n:}$ : phanerocotylar, the cotyledons becoming green; eophylls opposite, simple, entire; later ones becoming trifoliolate and imparipinnate. In E. bussei Harms and E. caudatum (Sprague) Sprague the hypocotyl becomes much enlarged and swollen.

Ch r o m os om e n u m b e s: $2 \mathrm{n}=36,72$ (7 species).

$\mathrm{D}$ i s $\mathrm{t} \mathbf{r}$ ibut $\mathrm{t}$ o n: Ir species in tropical Africa.

T y pe species: $E$. angolense (Welw.) C. DC.

$\mathrm{Rel}$ a $\mathrm{t}$ i o $\mathrm{sh}$ i p s: A very distinct genus. The long-pendulous fruits and the ridges which connect the staminal tube to the disk in the flower are features not seen in any other genus in the family. The capsules of some species of Cedrela are strikingly similar to those of Entandrophragma but those of the former genus are shortly stipitate at the base.

\section{CHUKRASIA}

Chukrasia A. Juss., Mém. Mus. Hist. Nat. Paris 19 (?1830) 251, fig. 22.; Harms in Engl. \& Prantl, Nat. Pflanzenfam. ed. 2, 19 bI (1940) 65, fig. 4 S, T. - Fig. 18c, d.

Plagiotaxis Wall. [Catal. No. 1269, 1270 (1829) nom. nud.] ex O. Kuntze, Rev. Gen. Pl. I (189I) 110. Chickassia Wight \& Arn., Prodr. Fl. Penins. Ind. Or. I (1834) 122.

Deciduous trees. Leaves imparipinnate; leaflets entire, unequally-sided; leaves of young trees mostly bipinnate with incised or lobed leaflets; glabrous or with simple hairs. Flowers large, 4 or 5-merous; unisexual, but with well-developed vestiges of the opposite sex present; thyrses axillary, usually shorter than the leaves. Calyx shallowly and irregularly divided or 4- or 5-lobed. Petals 4 or 5 , free, contorted, much longer than the calyx in bud, reflexed in open flowers. Staminal tube broadly cylindrical, narrowing towards the apex, or globet-shaped, entire or with a crenulate margin; anthers or antherodes attached to the margin. Disk in of flowers stipitate, scarcely distinguishable from the base of the pistillode; in o flowers narrowly cushion-shape. Ovary flask-shaped, 3-5-locular, each loculus with numerous ovules; style slender, style-head capitate with $3-5$ stigmatic ridges. Pistillode 
scarcely distinguishable from the pistil, loculi and rudimentary ovules well-developed; style-head thinner and less glandular. Fruit an erect, woody, ovoid or ellipsoid, septifragal capsule, opening by $3-5$ valves from the apex; the valves separating into an outer and an inner layer, the margin of the outer layer with coarse fibrous strands, the apex of the inner ones deeply bifid. Columella with 3-5 sharply-angled ridges, extending to the apex of the capsule; seed scars conspicuous. Seeds with a terminal wing, 80-100 per loculus, arranged laterally in tiers in the valve; endosperm present. Embryo with flattened subcircular cotyledons; radicle obliquely exserted.

Germ in a t i o n: phanerocotylar; cotyledons unequally-sided; eophylls opposite, irregularly imparipinnate, the leaflets lobed or irregularly-toothed; later leaves bipinnate.

Chrom os ome numbers: $n=13 ; 2 n=26$.

$\mathrm{D}$ is tribution: One or two species in India eastwards to Malesia and southern China.

T y pe species: C. tabularis A. Juss.

R e l a t i o n s h i p s: A very distinct genus easily distinguishable from other members of the Swietenioideae by its large flowers with a \pm entire staminal tube. The type of arrangement and number of seeds in each valve of the fruit are unique features in the subfamily.

\section{PSEUDOCEDRELA}

Pseudocedrela Harms, Bot. Jahrb. 22 (1895) I53; in Engl. \& Prantl, Nat. Pflanzenfam. ed. 2, I9 bI (1940) 67, t. II. - Fig. 18a, b.

Deciduous trees. Leaves pari- or imparipinnate, leaflets opposite or subopposite, sometimes \pm alternate, undulately lobed or dentate; indumentum of simple hairs. Flowers unisexual, but with well-developed vestiges of the opposite sex present, borne in short axillary thyrses. Calyx (4) 5-lobed almost to the base; lobes ovate or subcircular. Petals (4) 5 free, slightly contorted, much longer than the calyx in bud, boat-shaped and spreading in open flowers. Staminal tube urceolate, terminated by $8(\mathrm{ro})$ bifid reflexed lobes, the anthers or antherodes inserted between the deltate teeth of the lobes. Disk in $\delta$ flowers patelliform, fused to the base of the pistillode, but free from the base of the staminal tube; in $q$ flowers reduced to a ridge round the base of the ovary. Ovary 4- or 5-locular, each loculus with 4-6 ovules. Style-head large, discoid, almost completely blocking the entrance of the staminal tube, upper surface with 4 or 5 stigmatic lobes or ridges. Pistillode similar to the pistil but more slender and with a longer style; loculi well-developed, vestigial ovules minute. Fruit an erect, elongate, narrowly claviform, woody, septifragal capsule opening from the apex by 4 or 5 reflexing valves, the valves remaining firmly attached at the base connected by a fibrous network. Columella woody, sharply 4- or 5angled and extending to the apex of the capsule, indented with the imprints of the seeds; seed-scars inconspicuous. Seeds 4 or $s$ per loculus, with a terminal wing, attached by the seed-end to the distal part of the columella; endosperm present as a very thin layer. Embryo with thickened collateral cotyledons; radicle slightly exserted.

G e r m in a t i on: cryptocotylar; cophylls simple, opposite or spirally arranged, entire or with a sinuate margin.

Ch r om os ome number: $2 n=56$.

$\mathrm{D}$ is t r i b u t i o n: A single species in the Sudan zone of tropical Africa.

T y p e s p e cie s: $P$. kotschyi (Schweinf.) Harms.

Relationships: A very distinct genus and one of the few in the family with lobed leaflets. When first described it was placed by Schweinfurth (I868) in Cedrela, the 
fruit of which it resembles when unopened. Another specimen of the type species was placed by the same author in Soymida.

The curious fibrous network which holds the valves of the fruit together at dehiscence is seen again in the Andean genus Schmardaea.

\section{SCHMARDAEA}

Schmardaea Karsten, Fl. Columb. I (1861) 187, t. 93; Harms in Engl. \& Prantl, Nat. Pflanzenfam. ed. 2, 19 bl (1940) 69 t. 12, 13. - Fig. 18e, f.

Elutheria M. J. Roem., Synops. Monog. Hesperid. I (1846) 87, 122; non P. Browne (1756) nom. rejic. (= Guarea), nec Steud. (I 82I) nom. nud. (=Croton).

Small, much-branched, deciduous trees or shrubs. Leaves pari- or imparipinnate; leaflets with crenate, serrate, or coarsely dentate margins; indumentum of simple hairs. Flowers large, 4-merous, unisexual, but with well-developed vestiges of the opposite present; borne in very short, few-flowered, axillary thyrses. Calyx lobed \pm to the base, imbricate. Petals linear, contorted and much longer than the calyx in bud. Staminal tube broadly cylindrical, terminated by 8 shortly bifid or \pm entire appendages; the anthers or antherodes \pm included and alternating with the appendages; anthers large, the connective produced into a long thread-like appendage. Disk ridged, shortly stipitate, resembling a gynophore. Ovary 4-locular, each loculus with up to 25 ovules; style long and slender. Style-head narrowly discoid with 4 stigmatic lobes. Pistillode similar to the pistil but with a longer style and less differentiated style-head; loculi well-developed but vestigial ovules very small. Fruit an erect, thin-woody, fragile, ellipsoid or fusiform, septifragal capsule opening from the apex by 4 valves, the valves separating into two layers, the inner one membraneous, and remaining held together by a fibrous network. Seeds up to 20 per loculus with a terminal wing attached by the seed-end to the distal part of the central axis (? rudimentary columella); endosperm present as a thick layer. Embryo with thin, collateral cotyledons; radicle laterally exserted.

D istribution: Probably one species only in northern South America from Venezuela to Peru (Andean region).

T y p e s p e ci es: $S$. microphylla (Hook. f.) Karsten.

$\mathrm{Rel}$ a t i o n s h i p s: When the type of this little-known genus was first described by Hooker he placed it provisionally in Guarea as he had not then seen the distinctive fruit. Even now complete material in the form of undamaged capsules is not available for study. For this reason the nature and structure of the central columella is not known with certainty. Published drawings by Karsten and Harms also do not illustrate this satisfactorily. The woody, ridged columella so typical of the Swietenieae seems to be poorly developed in Schmardaea and the seeds are apparently attached to the dissepiments which become woody. In all other respects Schmardaea is typical of the tribe, although the large flowers and much-elongated thread-like connectives of the anthers are striking features rarely seen elsewhere in the family.

\section{SWIETENIA}

Swietenia Jacq., Enum. Pl. Carib. (1760) 4; Harms in Engl. \& Prantl, Nat. Pflanzenfam. ed. 2, 19 bI (1940) 70, t. 14. - Fig. 17g, h.

Mahagoni Adans., Fam. P1. 2 (1763) 343.

Roia Scopoli, Introd. (1777) 226.

Suitenia Stokes, Bot. Mat. Med. 2 (1812) 479. 

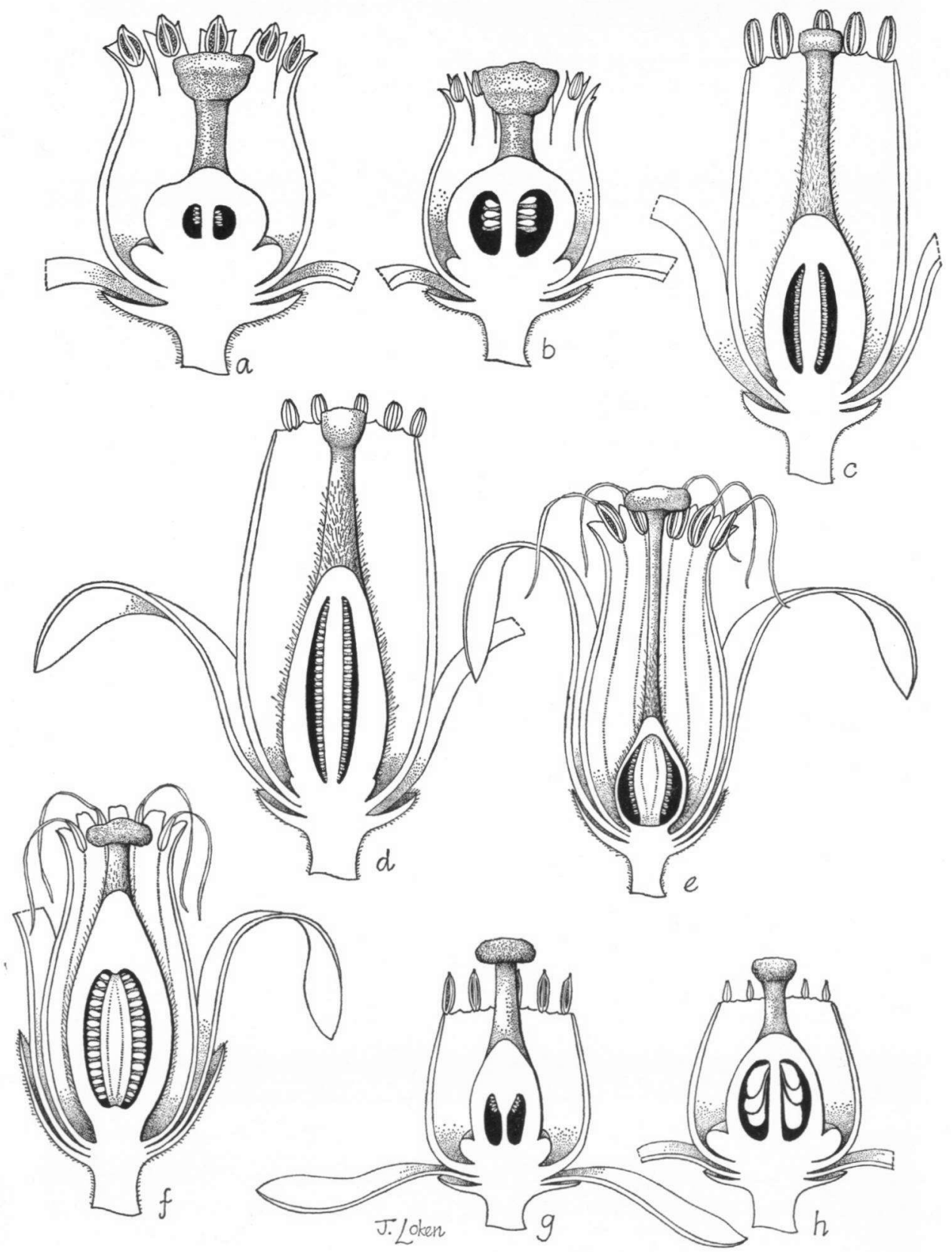

Fig. 18. a Pseudocedrela kotschyi (Schweinf.) Harms, 0 , $\times$ ro; b. ditto, $+9, \times$ ro. $-c$. Chukrasia tabulais A. Juss., $\delta, \times 5$; d. ditto, $\$, \times 5$. - e. Schmardaea microphylla (Hook.) Karst., $\delta, \times s ;$ f. ditto,, , $\times 5 .-$ g. Lovoa trichilioides Harms, J, $\times 5$; h. ditto, $9, \times$ s. (a, b. Styles 278; c. K. N. Bahadur s.n.; d. Kerr 19,631; e. Hooker s.n.; f. Sandeman s.n.; g, h. Styles 15). 
Deciduous trees. Leaves paripinnate, very rarely imparipinnate, leaflets entire, glabrous. Flowers unisexual, but with well-developed vestiges of the opposite sex present; borne in short, little-branched, axillary thyrses. Calyx s-lobed to about the middle, the lobes obtuse, imbricate. Petals (4) 5 , much longer than the calyx in bud, contorted, reflexed in open flowers. Staminal tube cup-shaped or urceolate, bearing on the inside 8-1o partially exserted apiculate anthers or antherodes and terminated by 8-ro deltate-acuminate or bluntly acuminate, non-overlapping appendages, alternating with the anthers or antherodes. Disk in $\delta$ flowers patelliform, fused to the base of the staminal tube, forming an annulus around the pistillode; in $q$ flowers reduced to a swelling at the base of the ovary. Ovary 5-locular, each loculus with I2-I6 ovules. Style-head discoid, \pm completely blocking the entrance to the staminal tube, the upper surface with s-stigmatic lobes. Pistillode similar to the pistil, but more slender, with a longer style and thinner style-head; the loculi well-developed but rudimentary ovules minute. Fruit an erect, strongly woody, oblong, ovoid, or obovoid, septifragal capsule, opening by 5 valves from the base or base and apex simultaneously, the valves separating into an outer thickly woody and an inner thinner layer. Columella woody, 5-angled, extending to the apex of the capsule; seed scars conspicuous. Seeds 9-I6 per loculus, attached by the wing-end to the apex (distal part) of the columella; the seed-body hanging towards the base of the capsule; endosperm present as a thin layer. Embryo with thin cotyledons; radicle slightly exserted.

Germination: cryptocotylar, cataphylls present; eophylls opposite, simple, entire; later ones trifoliolate or imparipinnate.

Ch r o m o s o m e $\mathrm{n}$ u m b e r s: $2 \mathrm{n}=48,54,56$ (3 species).

$\mathrm{D}$ is $\mathrm{trib}$ ution: 3 poorly defined species in tropical America (from Mexico to Brazil) and the Caribbean.

T y p e s p e ci e s: $S$. mahagoni (L.) Jacq. (see Styles, 1968).

Relationships: Most of the genera of the Swietenioideae when first described were placed in Swietenia, possibly because of the great similarity in overall structure of their fruits. The woody septifragal capsule with a central columella and winged seeds is characteristic of almost all genera in the Swietenieae. The secondary xylem of Swietenia is very similar to that of Khaya but there is no justification for uniting these genera as proposed by Lamb (I966).

\section{LOVOA}

Lovoa Harms in Engl. \& Prantl, Nat. Pflanzenfam. 3(4) (1896) 307; Bot. Jahrb. 23 (1896) I65.; in Engl. \& Prantl, Nat. Pflanzenfam. ed. 2, Ig bI (1940) 74, fig. I5. - Fig. 18g, h.

Litosiphon Pierre ex Harms in Dalla Torre \& Harms, Gen. Siphonog. (1901) 262; A. Chev., Vég. util. Afr. Trop. Franç. 9 (I9I7) I24.

Deciduous trees. Leaves paripinnate, leaflets entire, glabrous or with simple hairs. Flowers 4-merous, unisexual, but with well-developed vestiges of the opposite sex present, borne in large, showy, much-branched thyrses. Calyx lobed almost to the base, the lobes in an inner and outer whorl of $2+2$, imbricate. Petals 4 , free, imbricate, much longer than the calyx in bud; reflexed or spreading in open flowers. Staminal tube cup-shaped or shortly cylindrical, the margin entire or with very short teeth with 8 anthers or antherodes on the margin, or with paired deltate-acuminate appendages alternating with the anthers or antherodes. Disk short, broadly cushion-shaped, enveloping the base of the ovary or pistillode, but free from the staminal tube. Ovary 4-locular, each loculus with $4-6(-8)$ ovules. Style-head narrowly discoid or capitate, obscurely 4-lobed, \pm blocking the entrance of the staminal tube. Pistillode similar to the pistil but more slender, with a longer style and thinner style-head, the loculi well-developed, but vestigial ovules very 
small. Fruit a pendulous, elongate, tetragonal or ellipsoid, thinly woody, septifragal capsule, dehiscing from the apex or from base and apex simultaneously, the valves thinly woody. Columella softly woody, extending to the apex of the capsule, 4-ridged, each face shallowly indented with the imprints of $\mathrm{I}$ or 2 seeds. Seeds c. 2 per loculus, attached to the apex (distal part) of the columella by the wing-end, leaving inconspicuous scars on falling, the body of the seed hanging towards the base of the capsule; endosperm present as a very thin layer. Embryo with flat thin cotyledons; radicle slightly exserted.

G e r m in a t i o n: phanerocotylar; cataphylls present; eophylls opposite, pari- or imparipinnate, sometimes bipinnate; leaflets entire with a sinuous margin, reddish; rhachis broadly winged.

Ch r o m o s ome number: $2 n=50,52,56$ (Styles \& Khosla, unpublished).

$\mathrm{D}$ is $\mathrm{t} \mathbf{r} \mathrm{i}$ b u $\mathrm{t}$ i o n: 2 species in tropical Africa.

T y p e s p e ci es: L. trichilioides Harms.

Relationships: The position of Lovoa in the Swietenioideae has already been discussed (Chapt. 3). Although it differs from the majority of the genera in its wood structure it shares with these all the morphological (floral and fruit) characters found in this subfamily.

\section{Tribe 3. XYLOCARPEAE*}

Flowers without a gynophore. Petals free. Stamens 8-10, filaments completely united to form an urceolate or cup-shaped tube with appendages on the margin. Capsule subwoody or leathery with a rudimentary columella; seeds unwinged with a corky or woody sarcotesta; cotyledons large, fused together; endosperm absent.

Polle $\mathrm{n}$ and $\mathrm{S}$ e c ond a $\mathrm{r}$ y y $\mathrm{lem}$ as for the subfamily.

I. Inflorescence much-branched, many-flowered, $>25 \mathrm{~cm}$ long; sepals imbricate, \pm free to the base; leaflets $6-12(-18)$ pairs; seed with a woody sarcotesta 50. Carapa

Ia. Inflorescence little-branched, few-flowered, $<25 \mathrm{~cm}$ long (often very short); sepals valvate, united in the lower half; leaflets $(\mathrm{I}-)_{2}-3(-4)$ pairs; seed with a corky sarcotesta . . . . . . . . . . . . . sI. Xylocarpus

\section{CARAPA}

Carapa Aublet, Hist. Pl. Guian. Franç. 2 (1775) Suppl. 32, t. 387; Harms in Engl. \& Prantl, Nat. Pflanzenfam. ed. 2, 19 bI (1940) 77, t. 16, 17, 18; Noamesi, A revision of the XYlocarpeae, unpublished thesis Univ. of Wisconsin (1958) rs5 pp. - Fig. I6e, f.

Persoonia Willd., Sp. Pl. 2 (1799) 33 I; non Smith (1798) (Proteaceae), nec Michx. (1803) (= Marshallia Schreb. Compositae).

[Amapa Steud., Nom. ed. I (182I) 69, nom. nud.]

Zurloa Tenore in Atti 32 Riun. Sc. Ital. (184I) 504.

Touloucouna M. J. Roem., Synops. Monog. Hesper. I (1846) 123.

Racapa M. J. Roem. loc. cit.

Granatum Rumph. [Herb. Amb. 3 (1743) 92, tab. 61, 62] ex O. Kuntze, Rev. Gen. P1. I (1891) 110, p.p. (not. including the type).

Deciduous or? evergreen trees or treelets. Leaves paripinnate with a dormant glandular leaflet at the apex, or exceptionally imparipinnate, leaflets $6-12(-18)$ pairs, entire, glabrous or with simple hairs. Flowers $4^{-}$or 5-(6-)merous; unisexual, but with well-devel-

* In the present work we are following Noamesi (1958) in using the name Xylocarpeae (M. J. Roem., 1846) as the tribal name rather than the more usually accepted Carapear (Harms, I896). This is in accordance with Article II of the current edition of the International Code of Botanical Nomenclature (1972). 
oped vestiges of the opposite sex present, borne in large, much-branched, many-flowered, axillary thyrses. Calyx 4 - or 5 -lobed \pm to the base, the lobes rounded or broadly ovate, imbricate. Petals 4- or 5-(6), slightly contorted, longer than the calyx in bud, spreading in open flowers. Staminal tube cup-shaped, cylindrical, or urceolate, divided at the apex into 8-io entire, shortly bifid, or crenellately lobed appendages, and bearing on the inside alternately with the appendages $8-\mathrm{IO}(-\mathrm{I} 2) \pm$ sessile anthers or antherodes. Disk well-developed, cushion-shaped, surrounding the ovary and free from the staminal tube. Ovary 4 or $s(6)$-locular, partially sunk in the disk, with (2) $3-8$ ovules in each loculus; style short, style-head discoid, \pm blocking the entrance to the staminal tube, the receptive surface thickened and glandular. Pistillode similar to the pistil, but with a longer more slender style and thinner style-head; loculi well-developed, but rudimentary ovules small. Fruit a large, pendulous, sub-woody, sub-globose or oblong-cylindrical, septifragal capsule, opening by 4 or 5 valves from the base and apex simultaneously, the valves becoming leathery on drying; columella reduced, ultimately breaking down. Seeds large, 8-35, angular due to mutual compression, with the outer surface opposite the hilum rounded; sarcotesta woody, thick, smooth; endosperm absent. Embryo with the large cotyledons fused together; the radicle lying above the hilum.

G e r m in a t i o n: cryptocotylar; cataphylls spirally arranged; eophylls simple, entire; later ones trifoliolate, bright red.

Chromosome number: $2 n=58$ ( 2 species).

$\mathrm{D}$ is $\mathrm{t} \mathbf{r}$ ib u $\mathrm{t}$ i o n: A small genus of $c .3$ or 4 species in the Neotropics and west and central Africa.

Ty pe s p e cies: C. guianensis Aubl.

$\mathrm{Re}$ lationsh ips: These are discussed under Xylocarpus.

\section{XYLOCARPUS}

Xylocarpus Koen., Naturforscher 20 (I784) 2; Harms in Engl. \& Prantl, Nat. Pflanzenfam. ed. 2, 19 bI (I940) 81, t. 19; Noamesi, A revision of the XYlocarpeae, unpublished thesis Univ. of Wisconsin (1958) I55 pp.. Fig. $16 \mathrm{~g}, \mathrm{~h}$.

Carapa sensu Lam., Encycl. I (1785) 621 .

Monosoma Griff., Notul. 4 (1854) 502.

Granatum Rumph. [Herb. Amb. 3 (1743) 92, tab. 61, 62] ex O. Kuntze, Rev. Gen. I (1891) IIo p.p.; non St. Lag. (I880).

Semi-evergreen trees or shrubs. Leaves paripinnate, leaflets (I) 2 or $3(4)$ pairs, entire, glabrous. Flowers unisexual, but with well-developed vestiges of the opposite sex present, borne in short, little-branched, axillary thyrses. Calyx 4-lobed to about the middle, valvate. Petals 4, free, much longer than the calyx in bud, spreading or reflexed in open flowers; contorted in bud. Staminal tube urceolate or bowl-shaped, bearing 8 included anthers or antherodes towards the apex and terminated by 8 subcircular, retuse or shallowly and irregularly-lobed appendages alternating with the anthers or antherodes. Disk large, red, cushion-shaped, situated beneath, or surrounding and fused to, the ovary and free from the staminal tube. Ovary 4-locular, each loculus with 3 or $4(-6)$ ovules; style short, style-head discoid almost blocking the entrance to the staminal tube, margin crenellate, upper surface with 4 radiating stigmatic grooves. Pistillode similar to the pistil but with longer more slender style and thinner style-head; loculi well-developed, but rudimentary ovules small. Fruit a large, pendulous, almost spherical, leathery, septifragal capsule, tardily dehiscing by 4 valves from base and apex simultaneously; columella rudimentary, septa thin, ultimately breaking down. Seeds 8-20, large, pyramidal or tetrahedral, with angular margins due to mutual compression, outer side somewhat 
rounded, attached by the apex to the columella forming a spherical mass; testa corky, inlaid with fibres, smooth; endosperm absent. Embryo with the large cotyledons fused together; the radicle lying above the hilum.

Germin a t i o n: cryptocotylar, the numerous subulate cataphylls in whorls or spirally arranged; eophylls simple, entire, becoming trifoliolate later.

Chromos om e number: $2 n=52$ (2 species).

$\mathrm{D}$ is $\mathrm{t} \mathrm{r}$ i b u $\mathrm{t}$ i o $\mathrm{n}$ : An Old-World genus of two or three species in mangrove swamps or coastal scrub.

T y p e s p e ci es: $X$. granatum Koen.

Relati onships: Carapa and Xylocarpus are very closely related and have been combined by Lamarck ( 1785 ). They are, however, easily separable on a number of differential characters, the most important being the aestivation of the calyx and the nature of the sarcotesta. Biologically they represent a clear case of ecological specialization and generic allopatry in that Carapa occurs in forests of the Neotropics and in west and central Africa, whereas the more specialized Xylocarpus occurs in mangrove swamps and coastal scrub in the Old World. The corky testa of the seed in Xylocarpus represents an adaptation to dispersal by water.

The morphology of the seedlings of both is similar and specialized. There is an interesting difference in diploid chromosome numbers. 


\section{ANALYTICAL KEY TO THE IDENTIFICATION OF GENERA OF THE MELIACEAE}

Ia. Loculi I- or 2-ovulate (rarely with I or 2 additional vestigial ovules) . . . . 2

b. Loculi multiovulate. . . . . . . . . . . . . . . . \$2

2a. Leaves decussate; capsule with partial septifragal dehiscence 38. Capuronianthus

b. Leaves nearly always spirally arranged or fasciculate, very rarely decussate but then the capsule with loculicidal dehiscence

3a. Fruit dry; seed winged . . . . . . . . . . . . 37. Quivisianthe

b. Fruit fleshy or leathery, rarely woody; seed never winged . . . . . . . 4

4a. Fruit dehiscent. . . . . . . . . . . . . . s 5

b. Fruit indehiscent ......................... 36

sa. Disk free, cyathiform or tubular ............... 6

b. Disk annular, patelliform, stipitate, or absent, rarely cyathiform but then fused to the base of the staminal tube.

6a. Anthers inserted apically on the filaments or on the margin of the staminal tube 7

b. Anthers inserted within the throat of the staminal tube . . . . . . 8

7a. Staminal tube $1.5-3.0(-4.0) \mathrm{cm}$ long; ovary 5-locular; petals partly fused to the staminal tube; sarcotesta membraneous . . . . . . . . . I. Munronia

b. Staminal tube $0.25-0.5(-\mathbf{I} .2) \mathrm{cm}$ long; ovary 2- or 3-locular; petals free from staminal tube; sarcotesta, if present, not membraneous ..... Io. Trichilia

8a. Leaves with transparent gland dots and/or lines . . . . . . 26. Cabralea

b. Leaves without gland dots or lines . . . . . . . . . . 35. Dysoxylum

9a. Anthers inserted apically on the filaments or on the margin of the staminal tube .................... Io

b. Anthers inserted within the throat of the staminal tube . . . . . . . 22

roa. Anthers locellate; leaves showing limited apical growth or with a dormant apical bud ................ 30. Chisocheton

b. Anthers not locellate; leaves not showing limited apical growth; dormant apical bud absent . . . . . . . . . . . . . . . . . I I

Ira. Indumentum of stellate hairs or peltate scales, or a mixture of simple with bifid and/or stellate hairs ................... I2

b. Indumentum of simple hairs . . . . . . . . . . . . . . is

I2a. Filaments completely united . . . . . . . . . . . . . . I3

b. Filaments partly or completely free . . . . . . . . . . . . I4

r3a. Staminal tube long tubular . . . . . . . . . . . I. Munronia

b. Staminal tube short, globular or cyathiform . . . . . . . . . 20. Aglaia

I4a. Staminal tube appendages 3-ro times as many as filaments . I2. Pterorhachis

b. Staminal tube appendages not more than twice as many as filaments or absent

10. Trichilia

Isa. Leaves simple . . . . . . . . . . . . . . . . . . . . I6

b. Leaves trifoliolate or pinnate, rarely unifoliolate (with a pulvinus) . . . . I8

I6a. Filaments fused for two-thirds of their length or completely united 3. Turraea

b. Filaments usually fused only at the base, always free for more than half their length I7

17a. Capsule not inflated; filaments 0.6-I.I cm long, anthers basifixed 5. Calodecaryia

b. Capsule inflated; filaments $1.6-2.3 \mathrm{~cm}$ long, anthers dorsifixed 6. Nymania

I8a. Leaves trifoliolate, rarely unifoliolate . . . . . . . . . . . . I9

b. Leaves pinnate. . . . . . . . . . . . . . . 20 
19a. Staminal tube $2-3.5 \mathrm{~cm}$ long; filaments completely united, without appendages 2. Naregamia

b. Staminal tube not more than $0.6 \mathrm{~cm}$ long; filaments often free in the upper half and terminated by short appendages ............. I0. Trichilia

20a. Leaflets deeply lobed to partite . . . . . . . . . . 3. Turraea

b. Leaflets entire . . . . . . . . . . . . . . . . 2I

2ra. Capsule (4) S-valved, valves thick, woody, rugulose, bearing branched antler-like appendages . . . . . . . . . . . . II. Pseudobersama

b. Capsule 2 or $3(4)$-valved, valves usually thinner, less woody, sometimes warty but never with antler-like appendages ............ I0. Trichilia

22a. Style-head modified to form a receptaculum pollinis . . . . . . 3. Turraea

b. Style-head not modified to form a receptaculum pollinis . . . . . . . 23

23a. Anthers in 2 alternating whorls within the staminal tube. . 24. Sphaerosacme

b. Anthers in a single whorl . . . . . . . . . . . . . . . . 24

24a. Indumentum of stellate hairs or lepidote scales . . . . . . . . . 25

b. Indumentum of simple hairs . . . . . . . . . . . . . . 28

25a. Filaments free in the upper half and terminated by $(3)_{4}-6(-10)$ unequal filiform appendages ................ I2. Pterorhachis

b. Filaments completely united; appendages, if present fewer . . . . . . . 26

26a. Leaves with a dormant apical bud; staminal tube cylindrical 30. Chisocheton

b. Leaves without a dormant apical bud; staminal tube cyathiform or globular . 27

27a. Inflorescence a long spike or panicle with spicate branches; cotyledons fused, collateral ............... 22. Aphanamixis

b. Inflorescence paniculate, branches thyrsoid or indeterminate, rarely some female inflorescences reduced to a short spike; cotyledons free, nearly always superposed

20. Aglaia

28a. Sarcotesta greatly swollen, surrounding the base of seed . . . . . 27. Ruagea

b. Sarcotesta absent, or if present then not basal and swollen . . . . . . . 29

29a. The 2 seeds of a valve united by a common arillode. . . . . . . 32. Synoum

b. Seeds not united by a common arillode . . . . . . . . . . . . . 30

30a. Petals fused to the staminal tube for the greater part of its length 28 . Turraeanthus

b. Petals free from the staminal tube or fused only at the base. . . . . . . . 3 I

3Ia. Petals 3, imbricate; staminal tube globose or deeply cyathiform; style-head usually with large, conical, 3-angled stigma; cotyledons fused . . . 22. Aphanamixis

b. Petals $(3)_{4}-6(10)$, imbricate or valvate; staminal tube usually cylindrical; style-head discoid or capitate; cotyledons free . . . . . . . . . . . 32

32a. Leaves paripinnate . . . . . . . . . . . . . . . . . . 33

b. Leaves with a dormant terminal bud, or more rarely a terminal leaflet . . . 34

33a. Petals 3 or 4, valvate at least in the lower half; staminal tube cylindrical; loculi with 2 collateral ovules . . . . . . . . . . . 34. Pseudocarapa

b. Petals 5, imbricate; staminal tube cyathiform; loculi uniovulate 33. Anthocarapa

34a. Petals in 2 whorls, united below . . . . . . . . . 31. Megaphyllaea

b. Petals in a single whorl . . . . . . . . . . . . . . . 35

35a. Anthers nearly always locellate; style-head often capitate; seed often scutiform (ovule orthotropous), arillodiate or with a sarcotesta . . . 39. Chisocheton

b. Anthers never locellate; style-head discoid; seed never scutiform (ovule anatropous), exarillodiate, with a fleshy, mealy, or vascularised sarcotesta . . . 29. Guarea

36a. Disk tubular. . . . . . . . . . . . . . 36. Sandoricum

b. Disk annular, patelliform, stipitate, or absent . . . . . . . . . . . 37 
37a. Placentation parietal; berry rostrate . . . . . . . . 25. Heckeldora

b. Placentation axile; fruit not rostrate. . . . . . . . . . 38

38a. Anthers in 2 alternating whorls of $s$.... 23. Reinwardtiodendron

b. Anthers in a single whorl . . . . . . . . . . . . . . 39

39a. Leaves simple . . . . . . . . . . . . . . . . . 40

b. Leaves 2- or 3-pinnate, pinnate, trifoliolate, or rarely unifoliolate . . . . . . 42

40a. Style-head expanded to form a receptaculum pollinis; flowers long tubular

b. Style-head small; flowers small, cyathiform ..... . . . . . . 4I

4ra. Petals valvate; filaments or staminal tube bearing terminal appendages; loculi with 2 superposed ovules . . . . . . . . . . . 15. Malleastrum

b. Petals imbricate; filaments without appendages; loculi uniovulate or with 2 (3) collateral ovules ................. 9. Vavaea

42a. Leaves 2- or 3-pinnate ............. 7. Melia

b. Leaves not 2- or 3 -pinnate . . . . . . . . . . . . . 43

43a. Indumentum of stellate hairs or peltate scales ........... 44

b. Indumentum of simple hairs . . . . . . . . . . . . 46

44a. Corolla with valvate aestivation ......... I4. Lepidotrichilia

b. Corolla with imbricate aestivation . . . . . . . . . . . . . 45

45a. Style-head thick discoid; fruit a drupe with thin fleshy mesocarp and thick woody endocarp; seed with thick endosperm . . . . . . . . 17. Astrotrichilia

b. Style-head small, not discoid; fruit a berry or nut; seed without endosperm

20. Aglaia

46a. Fruit a berry. . . . . . . . . . . . . . . . 47

b. Fruit a drupe . . . . . . . . . . . . . . . . . 49

47a. Anthers inserted within the throat of the staminal tube; margin of staminal tube without appendages . . . . . . . . . . . 21. Lansium

b. Anthers inserted apically on filaments or on margin of staminal tube, these mostly with appendages . . . . . . . . . . . . . . . . . . 48

48a. Style-head minute, capitate; petals valvate; loculi with 2 superposed ovules

15. Malleastrum

b. Style-head well-developed, capitate, truncate, or pileate; corolla usually imbricate; loculi uniovulate or with 2 collateral ovules . . . . . . . 13. Walsura

49a. Corolla with valvate aestivation ... . . . . . . . . 19. Cipadessa

b. Corolla with imbricate aestivation .............. . so

soa. Loculi uniovulate . . . . . . . . . . . . . I8. Owenia

b. Loculi biovulate . . . . . . . . . . . . . . . . . . sI

51a. Style-head capitate or thick discoid; ovules superposed . . . . I6. Ekebergia

b. Style-head 3-lobed; ovules collateral .......... 8. Azadirachta

52a. Fruit indehiscent . . . . . . . . . . . . . 9. Vavaea

b. Fruit a septifragal capsule with a central columella (sometimes rudimentary) - $\$ 3$

53a. Stamens free . . . . . . . . . . . . . . . 54

b. Stamens partly or completely united into a staminal tube . . . . . . . . ss

54a. Seeds winged below, attached by the seed towards the apex (distal end) of the central columella; androgynophore column-shaped, longer than the ovary; first leaflets of seedlings entire.

39. Cedrela

b. Seeds winged at both ends, or if with one wing only then attached by the seed-end towards the base of the central columella (proximal end) and winged above; androgynophore cushion-shaped, shorter than or equalling the ovary; first leaflets of seedlings lobed or toothed. . . . . . . . . . . 40. Toona 
55a. Seeds without a wing. . . . . . . . . . . . . . . 56

b. Seeds winged . . . . . . . . . . . . . . . . . . $s 7$

56a. Inflorescence much-branched, many-flowered, $>25 \mathrm{~cm}$ long; sepals imbricate, \pm free to the base; leaflets $6-12(-18)$ pairs; seed with a woody sarcotesta 50. Carapa

b. Inflorescence little-branched, few-flowered, $<25 \mathrm{~cm}$ long (often very short); sepals valvate, united in the lower half; leaflets $(\mathrm{I}) 2$ or $3(4)$ pairs; seed with a corky sarcotesta

51. Xylocarpus

57a. Capsule globose, subglobose, or trigonous, not or scarcely longer than broad; seed orbicular to suborbicular, winged all the way round . . . . . . . . . 58

b. Capsule elongate, at least twice as long as broad, ovoid, obovoid, ellipsoid, claviform, or fusiform; seed with a single terminal wing or with a wing at both ends 59

58 . Capsule globose or subglobose, dehiscing by $4-6$ valves which remain joined together at the base; wing of seed narrow, opaque . . . . . . 4r. Khaya

b. Capsule \pm trigonous, the valves falling separately at dehiscence; wing of seed broad and transparent .............. 42. Neobeguea

59a. Seeds with a wing at both ends, the upper (distal) wing the longer 43. Soymida

b. Seeds with a single terminal wing . . . . . . . . . . . . . 60

6oa. Seeds very numerous, arranged laterally in tiers in each valve; margin of staminal tube entire or crenulate . . . . . . . . . . 45. Chukrasia

b. Seeds up to 20 per locule, attached by the seed- or wing-end towards the proximal (base) or distal (apex) part of the columella; staminal tube with appendages or variously divided, rarely entire . . . . . . . . . . . . . 6I

6ra. Seeds attached by the seed-end towards the distal end (apex) of the columella (i.e. seed winged below) . . . . . . . . . . . . . . . . . 62

b. Seeds attached by the wing towards the distal end (apex) of the columella (i.e. seed winged above) . . . . . . . . . . . . . . . . 64

62a. Leaflets undulately-lobed, crenate, or dentate; capsule erect, valves held together at dehiscence by a fibrous network . . . . . . . . . . . . 63

b. Leaflets entire; capsule pendulous, valves lacking a fibrous network; staminal tube lacking appendages .......... 44. Entandrophragma

63a. Capsule claviform or oblong; anthers or antherodes inserted between the bifid teeth of the lobes of the staminal tube; connective not produced 46. Pseudocedrela

b. Capsule ellipsoid or fusiform; anthers or antherodes inserted between the lobes of the staminal tube; connective produced, much elongated and threadlike

47. Schmardaea

64a. Capsule erect, large, very woody, ovoid or oblong; flowers mostly $s$-merous

48. Swietenia

b. Capsule pendulous, small, thin-woody, ellipsoid or tetragonal; flowers 4-merous

49. Lovoa

\section{SYNOPTIC KEY TO THE GENERA IN MELIACEAE}

The numbers correspond to those allocated in the codification list at the end of this key. Genera, cited under one lead only, are printed in bold type.

I. Bud scales

a. present: 39.40.41.42.43.44.45.46.47.48.49.50.5I.

b. absent: $1.2 .3 \cdot 4-5.6 .7 .8 .9 .10 .11 . I 2.13 .14 .15 .16 .17 .18 .19 .20 .21 .22 .23 .24 .25 .26 .27$. 28.29.30.31.32.33.34.35 -36.37.38. 
2. Leaf arrangement

a. spiral: I.2.3.4.5.6.7.8.9.I0.II.I2.I3.14.I5.I6.I7.I8.19.20.21.22.23.24.25.26.27

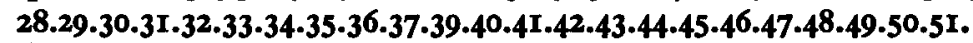

b. decussate: 38 .

3. Leaf type

a. simple: 1 .3.4.5.6.9.15.

b. unifoliolate: I0.13.15.20.23.

c. trifoliolate: I.2.10.12.13.15.17.20.23.36.

d. imparipinnate: I.3.8.IO.II.I2.I3.I4.I5.I6.I7.I9.20.2I.22.23.24.25.26.27.28.29.30. 31.32.35-37.38.39.40.45.46.47.48.50.

e. paripinnate: 8.IO.II.I7.18.20.2I.22.23.26.28.29.30.3 I.33-34-35.37.38.39.40.41.42. 43.44.46.47.48.49.50.5I.

f. terminal bud present: $29 \cdot 30.3 \mathrm{I}$.

g. bipinnate: 7 .

4. Indumentum type

a. simple: $2.3 \cdot 4 \cdot 5.6 .8 .9 .10 .11 .13 .15 .16 .18 .19 .21 .22 .23 .24 .25 .26 .27 .28 .29 \cdot 30.31 .32$. $33 \cdot 34 \cdot 35 \cdot 36.37 \cdot 38 \cdot 39 \cdot 40.4 I \cdot 42 \cdot 43 \cdot 44 \cdot 45 \cdot 46 \cdot 47 \cdot 48.49 \cdot 50.5 I$.

b. stellate hairs or peltate scales: I.7.I0.12.I4-17.20.22.30.

c. mixture of simple and bifid hairs: $\mathbf{I}$.

5. Leaflets with gland dots or lines

a. present: 10. 26. 27.29.

b. absent: $1.2 .3 \cdot 4 \cdot 5 \cdot 6.7 .8 .9 .10 .11 .12 .13 .14 \cdot 15.16 .17 .18 .19 .20 .21 .22 .23 .24 .25 .27$.

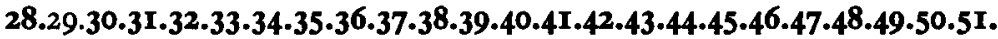

6. Sex distribution

a. monoecious: ?27.38.39.40.4I.42.43.44.45.46.47.48.49.50.5I.

b. dioecious: ?9.10.II.I2.I3.?14.?I5.16.? I 7.r8.20.21.22.24.25.26.?27.28.29.30.31.32. 33.35.37.

c. polygamous: 7.8.?9.13.19.

d. bisexual: I.2.3-4.5.6.9.14.15.17.21.22.23.?27.34-35.36.37.

7. Fusion of sepals

a. free: $4 \cdot 10.13 .18 .21 .22 .23 .24 \cdot 26.27 \cdot 35 \cdot 38.39 \cdot 40.41 .43 \cdot 44 \cdot 46.47 \cdot 49.50$.

b. partially united: 1.2.3.5.6.7.8.9.10.II.I2.I3.I4.I 5.I6.17.19.20.21.22.23.24.25.26.

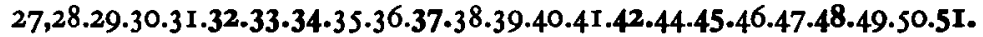

c. completely united: $3 \cdot 9.10 .15 .28 .29 .30 .31 .35 .36$.

8. Sepals foliaceous or not

a. foliaceous: I.3.

b. not foliaceous: 2.3 .4 .5 .6 .7 .8 .9 .10 .11 .12 .13 .14 .15 .16 .17 .18 .19 .20 .21 .22 .23 .24 .25 . 9. Calyx 26.27.28.29.30.31.32.33-34-35-36.37-38.39-40.4I.42.43-44-45.46.47.48.49-50.5I.

a. circumscissile at base: 29.30 .31 .35 .

b. not circumscissile at base: $1.2 .3-4-5.6 .7 .8 .9 .10 .11 .12 .13 .14 .15 .16 .17 .18 .19 .20 .21$. 22.23.24.25.26.27.28.29.30.32.33-34-35.36.37.38.39.40.4I.42.43.44.45.46.47.48. 49.50.51.

I0. Aestivation of calyx

a. valvate: $\mathbf{5 I}$.

b. not valvate (either imbricate, contorted, open or closed in bud): 1 .2.3.4.5.6.7.8.9. I0.11.12.13.I4.15.16.17.18.19.20.21.22.23.24.25.26.27.28.29.30.31.32.33-34-35. 36.37.38.39.40.41.42.43.44.45.46.47.48.49.50. 
II. Aestivation of corolla

a. imbricate: $1.2 .3 \cdot 4 \cdot 6.7 .8 .9 .10 .11 .12 .13 . I 6.17 .18 .20 .21 .22 .23 .24 .25 .26 .27 .29 \cdot 30.31$. 32.33-34.35.36.38.39.40.42.49.

b. valvate: $3 \cdot 10.13 .14 \cdot 15 \cdot 19 \cdot 28.29 \cdot 30.34 \cdot 35 \cdot 37$.

c. contorted: $3 \cdot 5 \cdot 9 \cdot 13 \cdot 38.41 .42 .43 \cdot 44 \cdot 45 \cdot 46.47 \cdot 48.50 .51$.

12. Corolla whorls
a. petals in a single whorl: 1 .2.3.4.5.6.7.8.9.I0.II.12.I3.I4.I5.16.17.18.19.20.2I.22. 23.24.25.26.27.28.29.30.32.33.34.35.36.37-38.39.40.4I.42.43.44-45.46.47.48.49. 50.51 .
b. petals in 2 whorls: 3 I.

13. Petal number
a. 3: 3.9.15.20.22.30.34.35.
b. 4: $2.3 .4 .5 .6 .9 .10 .13 .16 .20 .25 \cdot 28.29 \cdot 30.32 .34 \cdot 35 \cdot 36.38 .41 .42 .45 \cdot 46.47 \cdot 48.49 \cdot 50.51$.
c. more than 4: 1.2.3.4.5.7.8.9.10.II.12.13.I4.I5.I6.17.18.19.20.21.23.24.26.27.28. 29.30.31.32.33-35-36.37-38.39.40.4I.42.43-44-45.46.48.50.

14. Fusion of petals

2. petals fused to staminal tube or androgynophore: $1.20 .21 .22 .23 .28 .29 \cdot 30.31 \cdot 35.39$. 40.

b. petals free from staminal tube but gamopetalous (fused to halfway or more): 10.20 . 30.3I.

c. petals free from staminal tube, polypetalous or fused only at base: 1 .2.3.4.5.6.7.8.9. IO.II.I2.I3.I4-I5.16.17.18.I9.20.24.25.26.27.29.30.32.33.34-35.36.37.38.41.42. 43.44.45.46.47.48.49.50.5I.

I5. Union of filaments
a. filaments completely free from each other: IO.I 3.39-40.
b. filaments partially united: 3.5.6.9.I0.II.I2.I3.I4.I 5.I6.I8.19.44.
c. filaments completely united: $1.2 .3 .4 \cdot 7.8 .10 .14 .15 .16 .17 .18 .20 .21 .22 .23 .24 .25 .26$. 27.28.29.30.31.32.33.34.35.36.37.38.4I.42.43.44.45.46.47.48.49.50.5I.

16. Shape of androecium if filaments united
a. globose: 10.20 .21 .22 .23 .24 .
b. cyathiform: 3.5.6.9.I0.II.I3.I4.I S.I6.I7.I8.I9.20.21.22.23.24.32.33-38.4I.42.43 44.45.48.49.50.5I.
c. urceolate: IO.I2.I3.I4.I5.I6.I8.I9.20.21.22.23.37.38.4I.42.43.44.45.46.48.50.5I.
d. cylindrical: I.2.3.4.5.6.7.8.9.10.12.I4.I 5.I6.20.25.26.27.28.29.30.31.34-35.36.37. 38.45.47.49.50.

17. Filament appendages
a. apex of filaments or staminal tube bearing appendages, equalling the anthers in number or twice as many: 1.3.4.7.8.ro.13.14.15.18.19.26.29.30.33.34-35.36.38.41. 42.43.46.47.48.49.50.5I.
b. apex of filaments or staminal tube bearing appendages 3-Io times as many as anthers: $\mathbf{1 2 .}$
c. apex of filaments or staminal tube without appendages: 2.3.5.6.9.10.11.13.16.17. 20.21.22.23.24.25.27.28.29.30.31.32.35.37.39.40.44.45.49.

18. Ratio of anther number to petal number
a. anthers equalling petals in number: $10.20 .22 .30 .31 .35 .37 \cdot 39.40$.
b. anthers more than petals: 1 .2.3.4.5.6.7.8.9.10.I1.12.13.I4.15.16.17.18.19.20.21. $22.23 .24 \cdot 25.26 .27 \cdot 28.29 \cdot 30.31 .32 .33 \cdot 34 \cdot 35 \cdot 36.38 .41 .42 .43 \cdot 44 \cdot 45 \cdot 46.47 \cdot 48.49 .50$. 5 .


19. Anthers inserted

2. on ends of filaments or margin of staminal tube: 1 .2.3.4-5.6.7.8.9.ro.r1.12.13.1415.16.17.18.19.20.30.37.38.39.40.43.44.45.46.47.49.

b. within throat of staminal tube: $3.7 .8 .20 .21 .22 .23 \cdot 24 \cdot 25 \cdot 26.27 \cdot 28.29 \cdot 30.31 .32 .33$. 34.35.36.41.42.48.50.5I.

20. Number of whorls of anthers

a. a single whorl: 1.2.3.4.5.6.7.8.9.10.II.I2.I3.I4.15.I6.I7.18.19.20.21.22.25.26.27. 28.29.30.31.32.33.34-35.36.37-38.39.40.41.42.43.44-45.46.47.48.49.50.51.

b. two alternating whorls: 23.24 .

21. Anther connective

a. produced to form appendage: 1 .2.3.4.12.13.19.22.23.47.48.

b. not produced: I.3.5.6.7.8.9.10.II.I2.13.I4.15.16.I7.18.19,20.2I.22.24.25.26.27 28.29.30.31.32.33-34-35-36.37.38.39.40.4I.42.43.44-45.46.48.49.50.51.

22. Anthers

a. locellate: $\mathbf{3 0 . 3 1}$.

b. not locellate: 1.2.3.4.5.6.7.8.9.I0.II.I2.I3.I4.I5.I6.I7.I8.I9.20.21.22.23.24.25 23. Disk

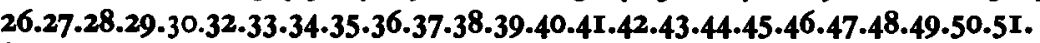

a. absent: I.2.9.I0.I4.I $5.17 .20 .21 .22 .23 \cdot 24 \cdot 28.29 \cdot 37 \cdot 38$.

b. patelliform, free from staminal tube: 7.10.13.30.33.

c. patelliform, fused to base of staminal tube or ovary: 3.4.5.6.9.10.11.16.17.19.34.37. 43.46.48.

d. stipitate: $10.25 \cdot 27 \cdot 29 \cdot 30.31 .45 .47$.

e. androgynophore: 39.40 .

f. cyathiform, fused to base of staminal tube or ovary: 3.4.9.10.35.

g. cyathiform, free: 10.26 .

h. tubular: 1.35.36.

i. annular or cushion shaped: 3.5.7.8.10.12.13.I5.I6.18.30.32.33.34.37-38.41.42.43. 44.45.46.48.49.50.5I.

24. Number of locules

a. I: 15.20 .25 .

b. 2 or 3: 2.3.8.9.10.12.I3.I4.I5.I6.I7.18.20.22.23.27.29.30.32.33-34-35.37.38.42.45

c. 4 or S: I.2.3.4.5.6.7.9.10.II.I3.I4.I 5.I6.I7.I8.19.20.2I.22.23.24.26.27.28.29.30.34 $35 \cdot 36.37 \cdot 38.39 \cdot 40.41 \cdot 43 \cdot 44 \cdot 45 \cdot 46 \cdot 47 \cdot 48 \cdot 49 \cdot 50.51$.

d. more than $5: 3.4 \cdot 7 \cdot 9.10 .16 .19 .29 .30 .31 .35 .50$.

25. Number of ovules per locule

a. locules all uniovulate: $9.13 .14 .18 .19 .20 .21 .23 .24 \cdot 30.31 .33$.

b. at least some locules with 2 collateral ovules: 2 .3.5.6.8.9.Io.II.I3.I7.19.20.22.23 25.30.32.34.35.36.37.

c. at least some locules with 2 superposed ovules: 1.3.4.7.10.12.15.16.17.20.22.26.27 28.29.30.35.

d. 2 and a vestigial one: 9.38 .

e. 3 to many ovules, ovules biseriate: $9.39 \cdot 40.41 .42 .43 \cdot 44 \cdot 45 \cdot 46.47 \cdot 48.49 \cdot 50.51$.

26. Style-head type

a. capitate, without conspicuous lobes: 1.3.5.6.9.I0.II.I2.I3.I4-I5.I6.I9.20.23.30.35. 37.38.45.49.

b. conical: 10.18.20.22.

c. discoid: $2.3 \cdot 5 \cdot 9.16 .17 .25 .26 .27 .28 .29 \cdot 30.31 .32 .33 \cdot 34-35 \cdot 39 \cdot 40.41 .42 .43 \cdot 44 \cdot 45.46$. 47.48.49.50.5I. 

d. pileate: 13.23 .24 .
e. bearing large stigmatic lobes: 7.8.10.36.
f. receptaculum pollinis: $\mathbf{2 . 3 . 4}$.
g. truncate: 21.22 .

27. Fruit
a. loculicidal capsule: 1 r.2.3.5.6.10.II.I2.20.22.24.25.26.27.28.29.30.31.32.33-34.35 37.
b. septifragal capsule: $38.39 \cdot 40.41 .42 .43 \cdot 44 \cdot 45 \cdot 46.47 \cdot 48.49 \cdot 50.5 I$.
c. berry: 4.9.13.15.20.21.23.25.
d. drupe: 7.8.14.16.17.18.19.36.
e. nut: 20.

28. Dehiscence of capsule, sometimes tardily
a. from apex: I.2.3.5.6.I0.II.12.20.22.24-26.27.28.29.30.31.32.33-34-35-37.38.39. 40.41.42.43.44.45.46.47.49.
b. from base: 44.48 .
c. from base and apex simultaneously: $44 \cdot 48.49 \cdot 50.5 \mathrm{I}$.

29. Fruit
a. inflated: 6.
b. not inflated: $1.2 .3 \cdot 4-5 \cdot 7.8 .9 .10 .11 .12 .13 .14 \cdot 15.16 .17 .18 .19 .20 .21 .22 .23 .24 .25 .26$. 27.28.29.30.31.32.33.34.35.36.37.38.39.40.4I.42.43.44.45.46.47.48.49.50.51.

30. Columella
a. present: $39 \cdot 40.41 .42 \cdot 43 \cdot 44 \cdot 45 \cdot 46 . ? 47.48 \cdot 49 . ? 50 . ? 51$.
b. absent: I.2.3.4-5.6.7.8.9.I0.II.I2.I3.I4.I5.I6.I7.I8.I9.20.21.22.23.24.25.26.27. 28.29-30.31-32-33-34-35-36.37-38.?47.?50.?51.

31. Fruit
a. with warts or appendages: I0.II.29.35.
b. without appendages: $1.2 .3 .4-5.6 .7 .8 .9 .10 .12 .13 .14 .15 .16 .17 .18 .19 .20 .21 .22 .23 .24$. 25.26.27.28.29.30.3I.32.33 -34-35.36.37.38.39.40.41.42.43 -44.45 •46.47.48.49.50. 51.

32. Seed
a. unwinged: 1 .2.3.4.5.6.7.8.9.10.I1.I2.I3.I4.15.16.17.18.19.20.21.22.23.24.25.26. 27.28.29.30.31.32.33-34-35.36.38.50.51.
b. winged: $37 \cdot 39 \cdot 40.4 \mathrm{I} \cdot 42 \cdot 43 \cdot 44 \cdot 45 \cdot 46.47 \cdot 48.49$.

33. Arillode and sarcotesta
a. arillode present: 2.3.IO.II.I2.13.20.21.22.24.26.30.32.34.35.
b. fleshy sarcotesta present: $4 \cdot 5 \cdot 6.8 .9 \cdot 10.17 \cdot 18.20 .23 .25 .27 .28 .29 \cdot 30.31 .33 \cdot 35.36$.
c. corky or woody sarcotesta present: 38.50 .5 I.
d. sarcotesta membraneous: $\mathbf{I}$.
e. arillode and sarcotesta absent: 7.13.I4.15.16.19.23.37-38.39.40.41.42.43.44.45.46. 47.48.49.

34. Union of arillodes
a. two collateral seeds united by common arillode: $\mathbf{3 2}$.
b. seeds not united by common arillode: 1.2.3-4.5.6.7.8.9.I0.II.I2.I3.I4.I5.I6.I7. I8.19.20.21.22.23.24.25.26.27.28.29.30.31.33-34·35.36.37.38.39.40.41.42.43. 44.45.46.47.48.49.50.5I.

35. Presence of swollen basal sarcotesta
a. seed with swollen basal sarcotesta (chalaza): 27. I8.r9.20.21.22.23.24.25.26.28.29.30.3I.32.33-34-35.36.37.38.39.40.4I.42.43.44. 45.46.47.48.49.50.5I.
b. seed without swollen basal sarcotesta: 1.2.3-4.5.6.7.8.9.10.Ir.r2.13.r4.15.16.17. 
36. Endosperm
a. present: I.2.3.4-5.6.7.8.9.10.II.I6.I7.I8.19.37.39.40.41.42.43-44.45.46.47.48.49.
b. absent: $9.10 .12 .13 \cdot 14 \cdot 15 \cdot 16.20 .21 .22 .23 \cdot 24 \cdot 25 \cdot 26.27 \cdot 28.29 \cdot 30.31 \cdot 32 \cdot 33 \cdot 34 \cdot 35 \cdot 36$. 38.50.5 r.

37. Cotyledons
a. flat: 1.2.3.4.5.6.7.10.17.19.37-39.40.41.42.43.44.45.47.48.49.
b. planoconvex: 8.9.10.II.I2.I3.I4.I5.16.18.20.21.22.23.24.25.26.27.28.29.30.3I. 32.33-34-35.36.38.46.50.5I.

38. Cotyledons, position
a. free, superposed: $20.21 .23 .28 .29 \cdot 30.31 .35$.
b. free, oblique: 14.15.20.29.30.35.38.
c. free, collateral: $1.2 .3 \cdot 4 \cdot 5 \cdot 6.7 .8 .9 .10 .11 .12 .13 .14 \cdot 15.16 .17 .18 .19 .20 .25 .26 .27 .29 .30$. 32.33-34-35.36.37-38.39.40.41.42.43.44.45.46.47.48.49.
d. completely fused together: $22.24 \cdot 50.51$.

39. Radicle, position

a. superior, exserted:1.2.3.4.5.6.7.8.10.11.12.I3.I4.15.16.18.19.26.27.36.37-38.39.40. 41.42.43.44-45.46.47.48.49.?50.?5I.

b. superior, included: 9.IO.II.I2.I3.I4.I 5.I 8.22.24.25.26.27.32.33-34.35.36.38.?50. ?51.

c. abaxial, exserted: 14.17.

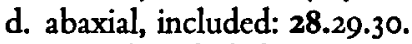

e. central, included: $20.21 .23 \cdot 29 \cdot 30.31$.

f. adaxial, included: $35 \cdot 38$.

Codification of the genera:

I =Munronia; $2=$ Naregamia; $3=$ Turraea; $4=$ Humbertioturraea; $5=$ Calodecaryia; $6 \Rightarrow$ Nymania; $7=$ Melia; 8=Azadirachta; 9 =Vavaea; $10=$ Trichilia; $11=$ =seudobersama; $12=$ Pterorhachis; $13=$ Walsura; I4 =Lepidotrichilia; I5 =Malleastrum; I6=Ekebergia; I7=Astrotrichilia; $18=O$ wenia; 19=Cipadessa; 20=Aglaia; $21=$ Lansium; $22=$ Aphanamixis; $23=$ Reinwardtiodendron; $24=$ Sphaerosacme; $25=$ Heckeldora; $26=$ Cabralea; $27=$ Ruagea; $28=$ Turraeanthus; $29=$ Guarea; $30=$ Chisocheton; $3 \mathrm{I}=$ Megaphyllaea; $32=$ Synoum; $33=$ Anthocarapa; $34=$ Pseudocarapa; $35=$ Dysoxylum; $36=$ Sandoricum; $37=$ Quivisianthe; $38=$-Capuronianthus; $39=$ Cedrela; $40=$ Toona; $41=$ Khaya; $42=$ Neobeguea; $43=$ Soymida; $44=$ Entandrophragma; $45=$ Chukrasia; $46=$ Pseudocedrela; $47=$ Schmardaea; $48=$ Swietenia; $49=$ Lovoa; $50=$ Carapa; $s I=X$ ylocarpus.

\section{ACKNOWLEDGEMENTS}

We would like to record our grateful thanks to Mr. F. White for introducing us to this botanically exciting and economically important plant family, and who has been one of the few modern exponents of the need for long term monographic studies of large families of tropical plants.

We are most grateful to the Directors of the following Herbaria and/or Institutions who have loaned us specimens or provided facilities for study:

The Forest Herbarium (BKF), Bangkok;

Herbarium of the University of California (UC), Berkeley;

Department of Botany (BM), British Museum (Nat. Hist.), London;

Jardin Botanique de l'Etat (BR), Brussels;

Central National Herbarium (CAL), Calcutta;

Arnold Arboretum (A), Cambridge;

Chicago Natural History Museum (F), Chicago;

Forest Research Institute (DD), Dehra Dun;

Royal Botanic Garden (E), Edinburgh;

Forestry Department (BSIP) Honiara;

Bernice P. Bishop Museum (BISH), Honolulu;

L. H. Bailey Hortorium (BH), Ithaca;

Forest Research Institute (KEP), Kepong; 
Royal Botanic Gardens (K), Kew;

Sarawak Museum (SAR), Kuching;

Rijksherbarium (L), Leiden;

Philippine National Herbarium (PNH), Manila;

The New York Botanical Garden (NY), New York;

Fielding Herbarium (OXF), Oxford;

Division of Botany, Department of Forests (LAE) Lae;

Muséum National d'Histoire Naturelle (P), Paris;

The East African Herbarium (EA), Nairobi;

Forest Department (SAN), Sandakan;

Herbarium of the Botanic Gardens (SING), Singapore;

Botanical Department Naturhistoriska Riksmuseum (S), Stockholm;

Botany Laboratory \& Herbarium, Department of Agriculture (SUVA), Suva;

U.S. National Herbarium, Smithsonian (US), Washington;

Laboratory for Plant Taxonomy \& Geography (WAG), Wageningen.

Thanks are due to Mr. F. White and Dr.D. J. Mabberley who have read this work in manuscript and who have offered much constructive criticism; to Dr. R. K. Brummitt for assistance with the nomenclature; to Mr. R. C. Palmer for help with the Latin diagnoses; to Mrs. J. Loken and Mrs. Rosemary Wise who have skilfully drawn the figures from our crude dissections; to Mrs. K. M. Conolly and our wives Hazel and Cynthia for their painstakingly typing of the several drafts of a difficult manuscript. Finally to Mrs. S. Dolan for much routine help in the preparation of the work for the final typing and for proof-reading.

One of us (TDP) gratefully acknowledges the receipt of a travel grant from the Leverhulme Trust Fund which enabled him to spend six months studying the Meliaceae in S. E. Asia and the Pacific Islands. The former Department of Scientific and Industrial Research provided financial support during the early stages of this study.

\section{REFERENCES}

AIRY-Shaw, H. K. 1937. In Hooker, Ic. Plant. 34 sub. t. 3333.

- 1966. In J. C. Willis; A Dictionary of the Flowering Plants \& Ferns; Ed. 7: I214.

ANON. 1957. International Glossary of Terms used in Wood Anatomy. Trop. Woods I07: I-36.

BAIIION, H. ?1874. Stirpes Exoticae Novae. Adansonia 11 : 239-273.

BatsCH, A. J. G. C. I802. Tabula affinitatum Regni Vegetabilis, 53.

Bentvelzen, P. A. J. I962. Reduction of the Genus Heynea Roxb. ex Sims to Trichilia P. Br. (Meliaceae). Acta Bot. Neerl. II: 1 I-20.

Bevan, C. W. L., T. G. Haisail, M. N. NwajI \& D. A. H. Taylor. 1962. West African Timbers. V. The structure of Khivorin, a constituent of Khaya ivorensis. Journ. Chem. Soc. 1962: 768-771.

BURGER, D. 1972. Seedlings of some tropical trees and shrubs of S. E. Asia. 228-258.

Candollb, A. P. DE I824. Prodromus Systematis Naturalis Regni Vegetabilis I: 619-626.

Candollb, C. DB 1878. In A. \& C. De Candolle. Monographiae Phanerogamarum I: 419-758.

Cavanilibs, A. J. I789. Monadelphiae classis dissertationes decem. Dissertatio Botanica 7: 359-370.

DADSwELL, H. E. \& D. J. EuIIS. I939. The Wood Anatomy of some Australian Meliaceae with methods for their Identification. C.S.I.R.O. Bull. 124, pp. 20.

Don, D. 1832. On Characters and Affinities of certain genera, chiefly belonging to the Flora Peruviana. Edinb. New Philos. Journ. 13: 242.

DukB, J. A. 1965. Keys to the identification of seedlings of some prominent woody species in eight forest types of Puerto Rico. Ann. Miss. Bot. Gard. 52: 314-350.

EARLB SmIth, C. 1960. A Revision of Cedrela (Meliaceae). Fieldiana, Botany 29(5): 295-34I.

ENGLER, A. I877. Studien uber die Verwandtschaftsverhältnisse der Rutaceae, Simaroubaceae und Burseraceae. Abhandl. Naturf. Ges. Halle 13(2): II $5-158$.

Erdtman, G. 1952. Pollen Morphology and Plant Taxonomy. pp. 539.

- 1966. Pollen morphology and Plant Taxonomy: Angiosperms (An Introduction to Palynology. I). pp. 553.

Forest Products Research Bulletin No. 25.1960. Identification of Hardwoods; a Lens Key. 126. pp.

GrIJPMA, P., \& B. T. STYLRs. I973. Bibliografía selectiva sobre Meliáceas, Turrialba pp. r43.

Harms, H. 1896. In A. Engler \& K. Prantl. Die Natürlichen Pflanzenfamilien 3(4): $258-308$.

- 1940. In A. Engler \& K. Prantl. Die Natürlichen Pflanzenfamilien, ed. 2, ig bI: I-1 72.

- in L. Diels. 1942. Beiträge zur Flora von Papuasien XXVI. Bot. Jahrb. 72: 16r.

Harrar, E. S. 1937. Notes on the Genus Flindersia R. Br. and the Systematic Anatomy of the Important Flindersian Timbers Indigenous to Queensland. Journ. Elisha Mitchell Sci. Soc. 53: 282-291.

HARTLEY, T. G. 1969. A revision of the genus Flindersia (Rutaceae). Journ Arnold Arb. so: 48I-526. 
HArvey, W. H. 1838. The Genera of South African Plants. Ed. I : 47.

- In W. H. Harvey \& O. W. Sonder. 1860. Flora Capensis I : 243.

HeImSCH, C. 1942. Comparative Anatomy of the Secondary Xylem in the Gruinales and Terebinthales of Wettstein, with reference to Taxonomic Grouping. Lilloa 8: 83-r98.

HiRRN, P. W. 1875. In J. D. Hooker. The Flora of British India I: $540-569$.

HofMeYre, J. I925. Short Notes. Journ. Bot. 63: 57.

Hooker, J. D. In G. Bentham \& J. D. Hooker, 1862. Genera Plantarum I: 327-340.

JACOBS, M. 1961. The Generic Identity of Melia excelsa Jack. Gard. Bull. Sing. 18: 71-75.

Jenkin, C. C. I96I. The Phylogeny of Two Genera as shown by Wood Anatomy. Unpublished Thesis, Oxford University. pp. 8.

Jussiru, A. L. DE. 1789. Genera Plantarum: 263-266.

Jussibu, A. DE. ?i830. Mémoire sur le Groupe des Méliacées. Mém. Mus. Hist. Nat. Paris I9: I53-304.

Kray, R. W. J. I958. Meliaceae, in Fl. W. Trop. Afr. I(2): 697-709.

KING, G. 1895. Materials for a Flora of the Malayan Peninsula. Journ. Asiat. Soc. Bengal. 64(2): 58.

Kostbrmans, A. J. G. H. 1966. A Monograph of Aglaia sect. Lansium Kosterm. (Meliaceae). Reinwardtia 7: $221-282$.

KRIBS, D. A. 1930. Comparative Anatomy of the Woods of the Meliaceae. Amer. Journ. Bot. 17: 724-738.

- 1950. Commercial Foreign Woods on the American Market. Edward Brothers. pp. I57.

LAmarck, J. B. A. P. 1785. Encyclopédie Methodique I: 621.

LAMB, F. B. 1966. Mahogany in Tropical America. pp. 220.

LEF, H. Y. I967. Studies in Swietenia (Meliaceae): Observations on the Sexuality of the flowers. Journ. Arn. Arb. 48: 10I-104.

LEROY, J. F. 19582. Recherches sur les Meliaceae: le Capuronianthus, genre nouveau endémique a Madagascar, type de la tribu des Capuroniantheae trib. nov., sousfamille des Carapoideae subf. nov. Compt. Rend. Acad. Sc. Paris 247: 1374-6.

- I958b. Recherches sur les Meliaceae: sur un genre africano-malgache, le Lepidotrichilia (Harms) J. F. Leroy. Compt. Rend. Acad. Sc. Paris 247: $1025-7$.

-I958c. Recherches sur les Meliaceae: sur un genre endémique 1 Madagascar, l'Astrotrichilia (Harms) J. F. Leroy (14 espèces). Compt. Rend. Acad. Sc. Paris 247: 1889-1891.

- r959. Sur une petite famille de Sapindales propre à l'A frique australe et à Madagascar: les Ptaeroxylaceac. Compt. Rend. Acad. Sc. Paris 248: roor-3.

- 1960a. Contributions d l'étude des Foréts de Madagascar. Complément a la note V sur les Ptaeroxylaceac. Journ. Agr. Trop. Bot. Appl. 7: 455-6.

- I960b. Structure du bois et classification. Bull. Soc. Bot. Fr. I07: 20-29.

- 1964. Recherches sur les Meliaceae: Le Malleastrum (Baill.) J. F. Ler., genre nouveau endémique de la Grande ile et des Comores. Journ. Agr. Trop. Bot. Appl. Ir : 127-149.

- 1969. Recherches sur l'évolution. Divergence évolutive de l'organisation ovarienne dans la tribu des Turraeeae (Meliaceae-Melioideae). Compt. Rend. Acad. Sc. Paris 269 D: 23 I9-2322.

LINNABUS, C. $f$. $178 \mathrm{I}$. Supplementum plantarum.

Maurrzon, J. 1936. Zur Embryologie und systematischen Abgrenzung der Reihen Terebinthales und Celastrales. Bot. Notis.: $161-212$.

Mrhra, P. N., T. S. SArekn \& P. K. Khosla. 1972. Cytological Studies on Himalayan Meliaceae. Joum. Arn. Arb. 53 : $558-568$.

Mehra, P. N., \& T. S. SAREBN. 1969. IOPB Chromosome Number Reports. Taxon 18 : 440.

Mrrrinl, E. D., \& L. M. Perry. I940. Plantae Archboldianae III (Meliaceae) Journ. Arn. Arb. 21 : $296-327$.

Mrtcarfe, C. R., \& L. Chalk. 1950. Anatomy of the Dicotyledons. 1500 pp.

Minfray, E. I9632. Contribution à l'étude caryo-taxonomique des Méliacées. Bull. Soc. Bot. Fr. I Io: I80-192.

- I963b. Le noyau et les chromosomes somatiques de deux Méliacées. Bull. Mus. Hist. Nat. Paris 35 : 527-531.

MolL, J. W., \& H. H. JANssonius. 1908. Mikrografie des Holzes 2 : 1 Io-21 4.

Panstrin, A. J. 1933. Comparative Anatomy of the Woods of the Meliaceae subfamily Swietenioideae. Amer. Journ. Bot. 20: 638-668.

Pelibgrn, F. 1909. Sur les genres Aglaia, Amoora et Lansium. Not. Syst. (Phanérogamie) I: $284-290$.

- 1939. Les Guarea (Méliacées) africains. Bull. Soc. Bot. Fr. 86: 146-I 54 .

- 1946-48. Méliacées. In H. Humbert (ed.), Supplément d la Flore Générale de l'Indochine. Fasc. 5: $683-700$ (1946). Fasc. 6: $701-728$ (1948).

Pennington, T. D. I965. A Taxonomic Study of the Meliaceac. Unpublished D. Phil. thesis. Bodleinn Library, Oxford, pp. 233.

- (in preparation). Structure and biology of the aril in the Meliacese.

Prich, J. R. 1952. The chemical constituents of Flindersia. Aust. Journ. Sc. Res. 54: 387-400. 
Radlkofer, L. 1890. Gliederung der Sapindaceen. Sitzungsber. Bayer. Akad. München 20: 105-319.

RAO, H. S. 1969. Chromosome Counts of New Forest Plants. Ind. For. 93: 243-254

RuTchiE, E., J. A. Bosson, \& M. Rasmussen. 1963. The chemical constituents of Australian Flindersia spp. Aus. Journ. Chem. 16: 480-90.

RoEmer, M. J. I846. Familiarum Naturalium Regni Vegetabilis Synopses Monographicae. I. Hesperides: 76-I5I.

SCHWEINFURTH, G. I868. Reliquiae Kotschyanae, Berlin. pp. 52.

Sxurch, A. F. 1946. A Compound Leaf with Annual Increments of Growth. Bull. Torrey. Bot. Club 75: $542-6$.

Smrrt, L. S. I959. New Species of and notes on Queensland Plants - IV. In Proc. Roy. Soc. Queensland 70: 29.

STYLEs, B. T. 1968. Swietenia mahagoni (L.) N. J. Jacquin. The correct name and authority for the West Indian or small-leaved Mahogany. An example of procedure in botanical nomenclature. Journ. Oxf. Univ. Forest. Soc. 6th ser.: 17-20.

- 1972. The Flower Biology of the Meliaceae and its Bearing on Tree Breeding. Silvae Genetica 21(s): 149-204.

- \& P. K. Krosta (in press). Karyological studies and chromosome evolution in Meliaceae. Silvae Genetica.

- \& C. G. Vosa. 1971. Chromosome Numbers in the Meliaceae. Taxon 20: 485-499.

TAYLOR, D. A. H. 1965. Extractives from E. African timbers I, Meliaceae. Journ. Chem. Soc. 1965: 34953496.

Thwartes, G. H. K. \& J. D. Hooker. 1858. Enumeratio plantarum Zeylaniae. pp. 59-61.

Thunberg, C. P. 1781. Physiographiska Sälskapets Handlingar I(3): 166.

Ventznat, E. P. 1799. Tableau du Règne Végétal selon la méthode de Jussieu 3: 159-166.

WhITE, C. T., in S. J. R. Record. 1931. Trop. Woods 25: 18, footnote.

WhITE, F. 1962. Geographic Variation and Speciation in Africa with particular reference to Diospyros. Syst. Assoc. Publ. 4: 7I-I03.

- \& B. T. STYLes. 1963. Meliaceae. Flora Zambesiaca 2: 285-319.

- \& - I966. Ptaeroxylaceac. Flora Zambesiaca 2: 547-50.

Wight, R., \& G. A. W. ARnotr. 1834. Prodromus florae peninsulae Indiae orientalis I: 116-1 24. 


\section{INDEX TO SCIENTIFIC NAMES}

New names are in bold type, synonyms in italics, accepted and other names in plain type. Page numbers in bold type refer to descriptions.

Acanthotrichilia (Urb.) Cook \& Collins 468.

Acrilia Griseb. 468.

Aglaia Lour. 428, 429, 430, 481.

sect. Lansium (Corr.) Kosterm. 483, 486.

Aglaieae 446, 450, 480.

Aglaiopsis Miq. $48 \mathrm{r}$.

Ailantopsis Gagnep. 468.

Aitonia Thunb. 460.

Alliaria Rumph. ex O. Kuntze 504.

Amapa Steud. 524.

Amerina Norohna 481.

Amoora Roxb. 48I, 482.

sect. Pseudo-Guarea C. DC. 500,502 .

Andersonia Roxb. 481, 485 .

Antelaea Gaertn. 463.

Antelaea auct. 464

Anthocarapa Pierre 500.

Aphanamixis Bl. 430, 432, 485 .

Argophyllum Blanco 481 .

Astrotrichilia (Harms) J. F. Leroy 434, 477.

Aytonia L. f. 460.

Azedarach Mill. 463.

Azadirachta A. Juss. 432, 464.

Azadirachtieae 427.

Barbilus P. Browne 467.

Barola Adans. 467.

Beddomea Hook. f. 481 .

Bersama 426, 47 I.

Bingeria A. Chev. 493.

Cabralea A. Juss. 429, 432, 491.

Calodecaryia J. F. Leroy $431,459$.

Calodryum Desv. 455.

Cambania Comm. ex M. J. Roem. s04.

Camunium Rumph. ex Roxb. 481.

Capuronianthoideae 432, 436, 445, 450, 509.

Capuronianthus J. F. Leroy 428, 433, 444, 509.

Carapa Aubl. 429, 432, 435, 444, 524 .

Carapa sensu Lam. 525 .

Carapeae 427, 446.

Carapoideae 444.

Carruthia O. Kuntze 460.

Cedrela P. Browne 428, 431, 435, 437, 443, 512. sect. Toona Endl. 512 .

Cedrelaceae 424, 425, 440.

Cedreleae 424, 426, 427, 450, 511.

Cedreloideac 427, 443.

Cedrelopsis 425, 442.

Cedrus Mill. 512.

Charia C. DC. 476.

Chloroxylon 438, 44r.

Chickrassia Wight \& Arn. SI9.

Chisocheton BI. 428, 497.

Chukrasia A. Juss. 428, $431,437,519$.
Chuniodendron $\mathrm{Hu} 485$.

Cipadessa Bl. 431, 479. sect. Malleastrum Baill. 475 .

Clemensia Merr. 497.

Cuveraca Jones 512.

Dasycoleum Turcz. 497.

Didymocheton Bl. 504.

Disyphonia Griff. 504 .

Dysoxylum Bl. 428, 429, 504.

Ekebergia Sparrm. 429, 476. pterophylla (C. DC.) Hofm. 480.

Elcaja Forsk. 467.

Elutheria P. Browne 494, 52I.

Elutheria M. J. Roem. 494.

Entandrophragma C. DC. 428, 431, 437, 518.

Epicharis B1. 504.

Euphora Griff. $48 \mathrm{I}$.

Flindersia 438, 44I.

Flindersiaceae $44 \mathrm{I}$.

Garretia Welw. 515.

Geniostephanus Fenzl 467.

Gilibertia J. F. Gmel. 455.

Ginnania M. J. Roem. 455.

Granatum Rumph. ex. O. Kuntze 524, 525.

Grevellina Baill. 455.

Guarea Allam. ex L. 429, 433, 494 .

sect. Heckeldora (Pierre) Harms $49 \mathrm{r}$.

Guarea sect. Ruagea C. DC. 492.

Guareeae 446, 450, 489.

Guidonia Mill, 494.

Harpagonia Noronha 504

Hartigshea A. Juss. 504 .

Hearnia F. Muell 481.

Heckeldora Pierre 433, 491.

Heimodendron Sillans 518.

Heynea Roxb. ex Sims 467.

Heynichia Kunth 467.

Humbertioturraea J. F. Leroy 458.

Johnsonia Adans. 512.

Khaya A. Juss. 428, 436, 515, 518.

Lachanodendron Reinw. ex Bl. 483.

Lamiofrutex Lauterbach 464.

Lansium Rumph ex. Corr. 432, 433, 483 .

sect. Neolansium Harms $483,486$.

sect. Pseudolansium Harms 488.

humile Hassk. 488.

Leioptyx Pierre ex De Wild. si8.

Lepiaglaia Pierre $48 \mathrm{I}$.

Lepidotrichilia (Harms) J. F. Leroy 433, 437, 473. 
Leplaea Vermoes. 494

Litosiphon Pierre ex Harms 523.

Lovoa Harms 428, 436, 523.

Lovoinoidese 423.

Macrochiton M. J. Roem. 504.

Mafureira Bertol. 467.

Mahagoni Adans. 52I.

Mallea A. Juss. 479.

Malleastrum (Baill.) J. F. Leroy 433, 437, 475.

Megaphyllaea Hemsl, 429, 430, 498.

Melia L. 428, 433, 463 .

Meliaceae 448.

Meliadelpha Radlk. 504.

Melieae 424, 425, 427, 446, 450, 462.

Melioideae 427, 429, 437, 443, 445, 450, 451.

Melio-Schinzia K. Schum. 497.

Melospermum Scortech. ex King 472.

Merostela Pierre 481.

Milnea Roxb. $48 \mathrm{I}$.

Monosoma Griff. 525 .

Moschoxylum A. Juss. 467.

Monocyclis Wall. ex Voigt 472.

Munronia Wight 428, 429, 452.

Napeodendron Ridley 472.

Naregamia Wight \& Arn. 428, 43 I, 454.

Nelanaregam Adans. 454.

Nemedra A. Juss. 48I.

Neobeguea J. F. Leroy 436, 516.

Nimmoia Wight 481.

Nurmonia Harms 455 .

Nyalelia Dennst. $48 \mathrm{I}$.

Nymania S. O. Lindb. 434, 443, 460.

Odontandra Willd. ex M. J. Roem. \& Schultes 467 .

Odontosiphon M. J. Roem. 467.

Oraoma Turcz. 481.

Owenia F. Muell 429, 433, 478 .

Payeria Baill. 455 .

Persoonia Willd. 524.

Philastrea Pierre 452.

Pholacilia Griseb. 468.

Picroderma Thorel ex Gagnep. 468.

Plagiotaxis Wall. ex O. Kuntze s19.

Plumea Lunan 494.

Plutea Noronha 483.

Portesia Cav. 467.

Prasoxylon M. J. Roem. SO4.

Pseudobersama Verdcourt 432, 437, 469.

Pseudocarapa Hemsl. 429, 502.

papuana Merr. \& Perr. 503.

Pseudocedrela Harms 520.

Ptaeroxylon 425, 435, 42.

Ptaeroxylaceae 425, 442.

Pterorhachis Harms 425, 435, 442, 443, 471.

Pterosiphon Turcz. 512.

Quivisia Cav. 455.

Quivisianthe Baill. 445, 508.

Quivisianthoideae 445, 450, 508.

Racapa M. J. Roem. $\$ 24$

Reinwardtiodendron Koord. 486.
Rhetinosperma Radlk. 497.

Ricinocarpodendron Boehm. 504.

Rochetia Delile 467.

Roia Scopoli 521.

Ruagea Karst. 434, 492.

Rutaceac 435, 441, 442.

Rutaea M. J. Roem. 455.

Samyda L. 494.

Sandoriceae 446, 450, 507 .

Sandoricum Rumph. ex. Cav. 428, 432, 507.

harmandii Pierre 508.

Sapindaceae 435, 443, 462.

Schizochiton Spreng. 497.

Schmardaea Karst. 432, 521.

Scyphostigma M. J. Roem. 455.

Scytalia Ham. ex. Wall. 472.

Selbya M. J. Roem. 481.

Soymida A. Juss. 518

Sphaerosacme Wall. ex M. J. Roem. 485, 488. decandra (Wall.) Pennington 489.

Suitenia Stokes s2r.

Surenus Rumph. ex. O. Kuntze 512.

Surwala M. J. Roem. 472.

Swietenia Jacq. 428, 437, 521.

Swieteniaceae 435.

Swietenieae 426, 427, 451, 513.

Swietenioideae 427, 429, 432, 436, 443, 450, sII.

Sycocarpus Britton 494.

Symphytosiphon Harms 468.

Synoum A. Juss. 434, 499.

Toona (Endl.) M. J. Roem. 428, 432, 435, 443, 512.

Torpesia (Endl.) M. J. Roem 467

Touloucouna M. J. Roem. 524

Trichilia P. Browne 429, 431, 467

sect. Acanthotrichilia Urb. 468, 495.

Astrotrichilia Harms 447, 469, 477.

Eutrichilia C.DC. 475.

Lepidotrichilia Harms 447, 473.

Peltotrichilia Harms 447, 469, 477.

Pterotorhachis Harms 469, 475.

Pterotrichilia Harms 469, 476.

Torpesia Endl. 467.

Trichilieae 424, 425, 427, 432, 446, 450, 466

Turraea L. 428, 430, 43I, 437, 455.

breviflora Ridl. 458 .

pulchella (Harms) Pennington 454.

Turracanthus Baill. 430, 493.

Turraceac 427, 428, 434, 439, 446, 450, 451 .

Turraeopsis Baill. 493.

Urbanoguarea Harms 494

Vavaea Benth. 428, 464.

Vavaceae 427, 446, 450, 464.

Walsura Roxb. 429, 432, 472.

Wulfhorstia C.DC. 518 .

Xylocarpeae 451, 524.

Xylocarpus Koen. 430, 432, 435, 444, 525.

Zederachia Heist. ex. Fabr. 463.

Zurloa Tenore 524. 